Historic, archived document

Do not assume content reflects current
scientific knowledge, policies, or practices. 

62,63

\section{ASHEVILLE SEED COMPANY} ASHEVILLE, N. C.

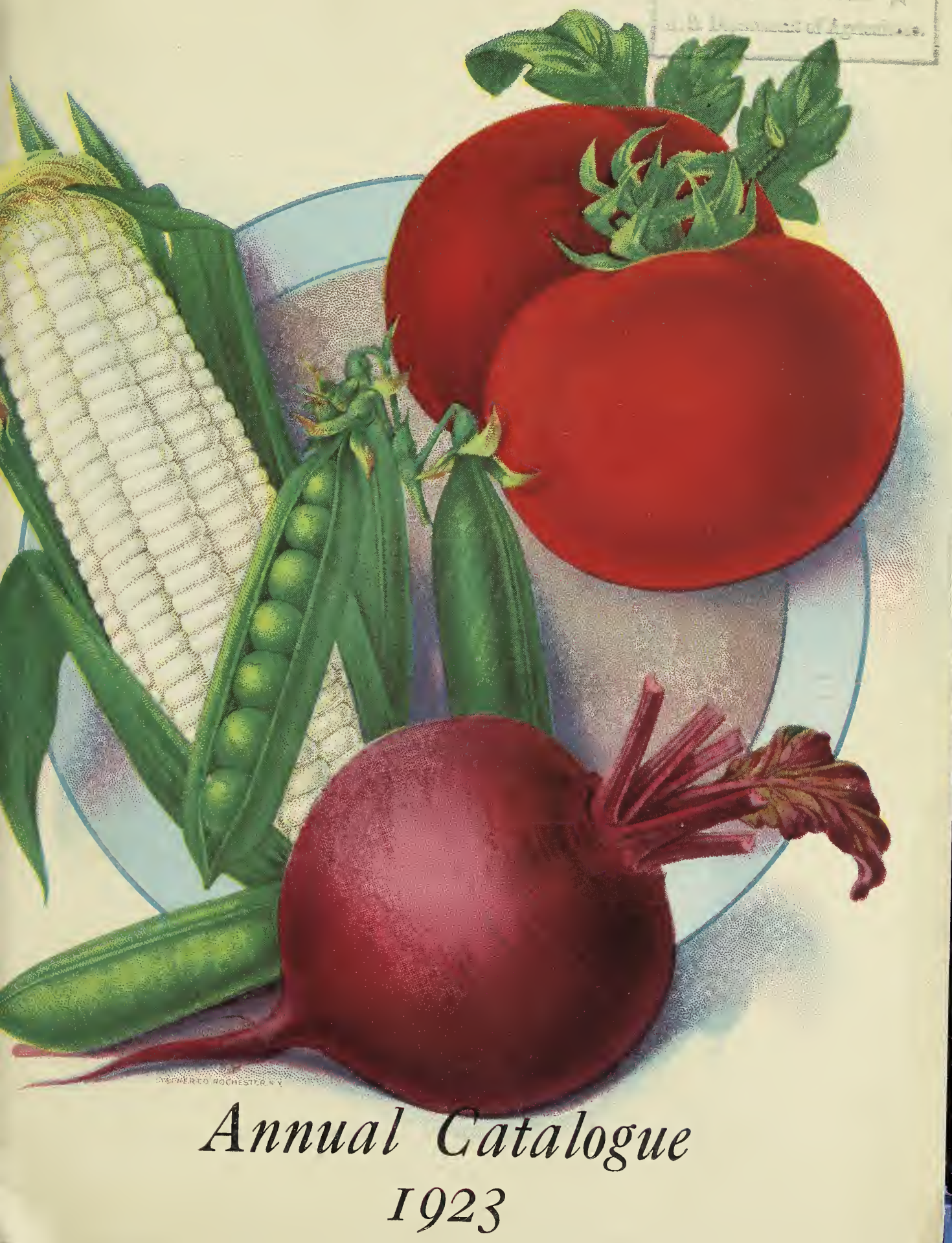




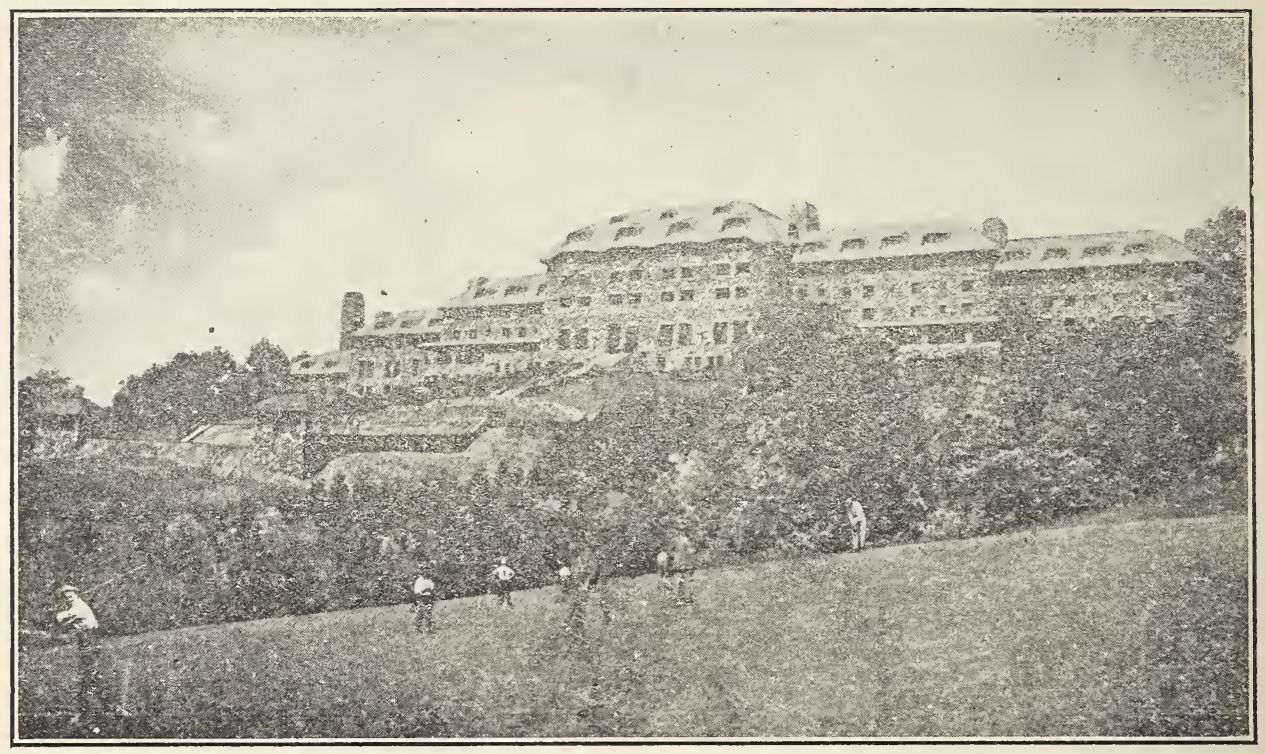

\section{Grove Park Evergreen Lawn Grass}

In the South we often have trouble in getting good lawns, because it has been found that no one grass will give satisfactory results at all seasons and on all soils. By careful experiment, we have succeeded in getting a combination of grasses that will produce an evergreen lawn. Each variety of grass in the Grove Park Ever- green Lawn serves a special purpose, some being selected for their color values, others for their growing habits, and still others for their hardiness; all of these varieties blended together produce the coveted thick turf and velvet appearance. Postpaid-Lb. 50c; 101bs. $\$ 4.00$.

Express-Lb. 40c ; 10 tbs. $\$ 3.50100$ tbs. $\$ 30$.

\section{Shady Park Lawn Grass}

Few grasses grow well in shaded portions of lawns or groves, hence it is necessary to sow a mixture of grasses which are adapted for growing in the shade. Our Shady Park Mixture pro- duces an abundant and even growth of beautiful grass in the shade.

Postpaid: Lb. 60c; 10 tbs. $\$ 5.00$

Express-Lb. $50 \mathrm{c} ; 10 \mathrm{lbs}$. $\$ 4.50 ; 100$ tbs. $\$ 40.00$.

\section{How to Secure a Beautiful Lawn}

THE PREPARATION OF THE SEED BEDAll weeds, roots, and other debris should be removed and the soil stirred thoroughly to the depth of eight or ten inches. Of course large areas can only be plowed and disked; however. small lawns should be spaded and pulverized like garden soil prepared for the reception of small seed.

FERTILIZATION-Grass seed send out long feeding roots which absorb a large quantity of plant food in making heavy green turf. It is necessary to mix fertilizer to the depth of eight or ten inches to supply this plant food. The class of fertilizer used will have a direct bearing on the finished lawn. To avoid numerous noxious weeds that always come by the use of fresh manure, we advise fertilizing your lawn with Pulverized Sheep Manure, a natural fertilizer, free from all weed seed. Ground Bone Meal is also valuable as an enricher of lawns and a top dressing. Bone Meal or Sheep Manure or a mixture, half of each, should be applied at the rate of $30 \mathrm{tbs}$. for 300 square feet, or $1,000 \mathrm{lbs}$. for an acre. As a top dressing $500 \mathrm{lbs}$. for an acre or $15 \mathrm{lbs}$. to 300 square feet.

Ants which frequently infest lawns can easily be driven off by the use of Tobacco Dust which is also a good fertilizer.
LIMING THE SOIL-The soil in this section is lacking in lime and blue grass particularly requires lime. We recommend the use of Agriculture Lime at the rate of $100 \mathrm{lbs}$, to 300 square feet or 4 to 5 tons to the acre. It is best to apply lime in the winter or early spring but not within three months of applying fertilizer.

SOWING THE SEED-For spring sowing, Lawn Grass Seed should be sown as early as possible, from February to May, or if in the fall, from September to the last of November. Many people follow the practice of sowing lawn grass seed on top of snow with very great success. As the snow melts the seed is carried to the proper depth. Thick seeding gives the best results. It should be sown at the rate of one pound to 300 square feet or 100 pounds to an acre. The seed should be carefully and everily sown, lightly raked in, and afterwards, provided the soil is not too wet, rolled or made firm by patting down with the back of a spade. This packing brings the seed in close contact with the soil and prevents drying out; it also gives a quicker and a more even germination.

Lawns should not be neglected. The grass should be kept cut and watered in dry weather. Bare spots must be re-seeded if the lawn is to present a velvety appearance. 
ORDER BLANK FOR SEEDS, ETC.

ASHEVILLE SEED CO., gives no warranty. expressed or implied, as to description, quality, productiveness, or any other matter, of any seeds, bulbs or plants they send out, and they will not be in any way responsible for the crop. If the purchaser does not accept the goods on these terms, they are at once to be returned.

\section{ASHEVILLE SEED COMPANY,} ASHEVILLE, N. C.
Please Do Not Write Here

Date Received

Date Filled

Filled by

Shipped by

Order No.
Date $-19$

PLEASE TILL IN THESE BLANKS PLAINLY

Dear Sirs:-

Please send the following Seeds, etc., by (State here if wanted by Mail, Express or Freight)

Name

P. O. Box

Post Office R. F. D

County State

\section{Amount Enclosed}

Check

P. O. Money Order

Exp. Money Order

Cash

Stamps

Express or Freight Office

(If different from Post Office)

ABOUT PRICES:-We pay postage on PACKETS, OUNCES, AND QUARTER POUNDS; all prices in this Catalogue, excepting where otherwise noted, are based on customer paying Express or Freight. See Parcel Post Rates Page 3

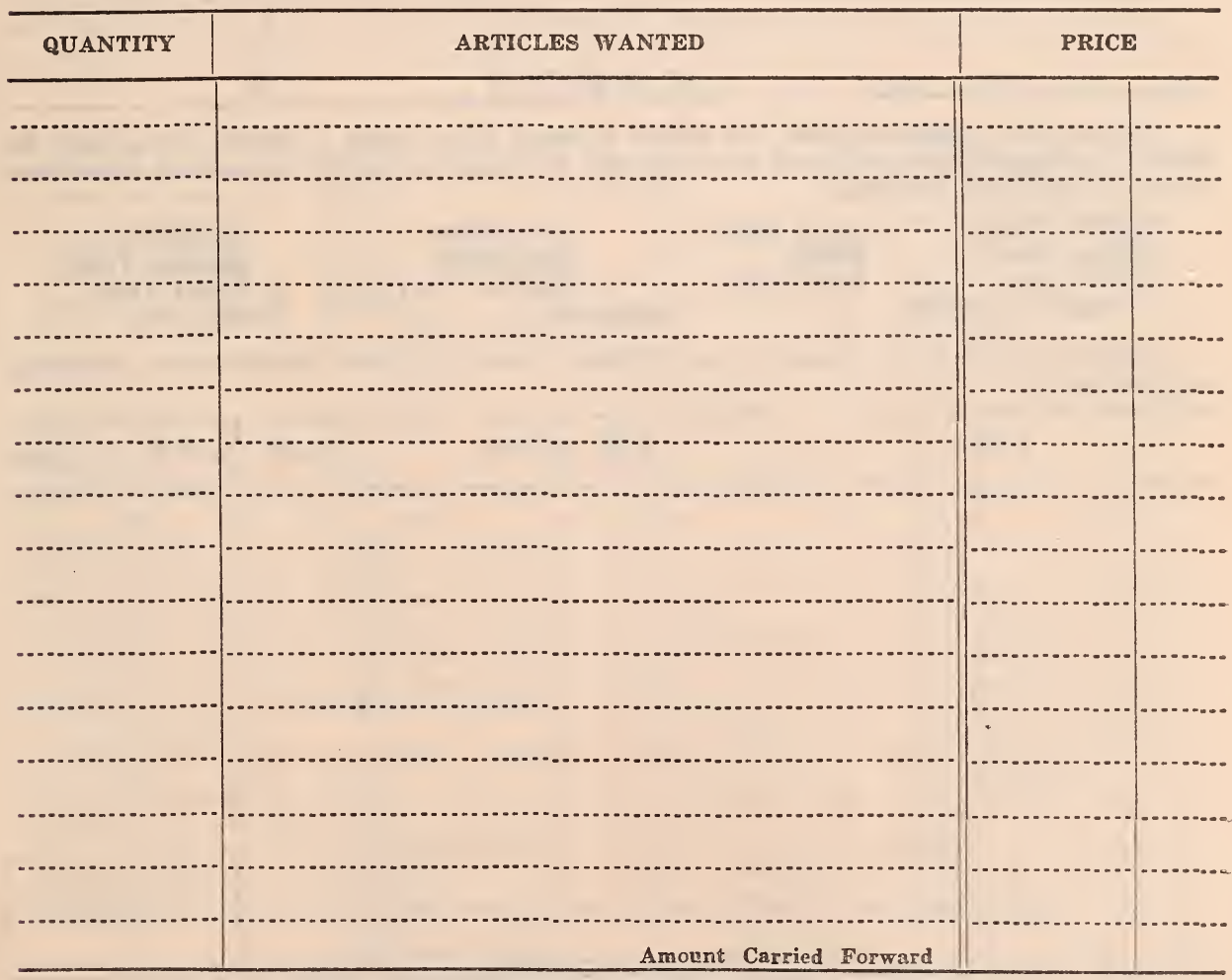


EXTRA ORDER SHEETS AND RETURN ENVELOPES FURNISHED ON REQUEST

\begin{tabular}{c|c||c|}
\hline QUANTITY & ARTICLES WANTED & \multicolumn{2}{c}{ PRICE } \\
\hline & &
\end{tabular}

By carefully checking this list before sending your order, a great saving may be made in transportation cost, and you may also find that an important and an immediate necessity has been omitted.

$\begin{array}{ll}\text { Garden Seed } & \text { Lawn Seed } \\ \text { Flower Seed } & \text { Bulbs } \\ \text { Field Seed } & \text { Fertilizers } \\ \text { Poultry Supplies } & \end{array}$

\section{Insecticides \\ Fungicides}

Incubators

\section{Sprayers \\ Garden Tools \\ Lawn Tools}

Feeds, Etc.

Kindly list below the names of any friends whom you think interested in receiving our catalogue.

\begin{tabular}{c|c|c|c|c|}
\hline NAME & POST OFFICE & STATE & R. F. D. & P. 0. Box \\
\hline & & & & \\
\end{tabular}




\section{TO OUR CUSTOMERS:}

In presenting our 1923 catalogue, we wish to thank the many customers who have contributed to the growth of our business; and that have made it possible for us to offer at all times, the very best grade seeds at the very lowest market price.

We earnestly solicit the orders of those, who have never been our customers. We know that you will be more than pleased with the merchandise we have to offer and it will give us great pleasure to serve you.

We realize fully the responsibility you must place on us when ordering seed; and for this reason we purchase nothing but the very best seeds from the best growers. These seeds are thoroughly tested by us and by the seed test department at Raleigh. Each bag of field seed sent out by us bears a tag showing the purity and germination and the name of the seed. Examine the tag and the seed carefully before sowing to see that you received just what you purchased. Each package of vegetable and flower seed is marked with the kind of seed it contains. Examine the name and contents carefully and if you find that you have not received what you ordered, return at once and your money will be refunded.

We have the utmost confidence in all the seeds we have to offer and it should be apparent to the most skeptical that we could not afford to send out inferior seeds; as there would be no surer way of destroying our business. As we have no control of seeds after they leave our hands and as weather conditions, methods of planting, cultivating and fertilizing, play such an important part in the out turn of any crop, the Asheville Seed Company give no warranty, expressed or implied, as to description, quality, productiveness, or any other matter of any seeds, bulbs or plants they send out and they will not be in any way responsible for the crop. If the purchaser does not accept the goods on these terms they are at once to be returned.

We sincerely hope that you may have a successful crop the coming season.

Most Cordially Yours,

\section{ASHEVILLE SEED COMPANY}

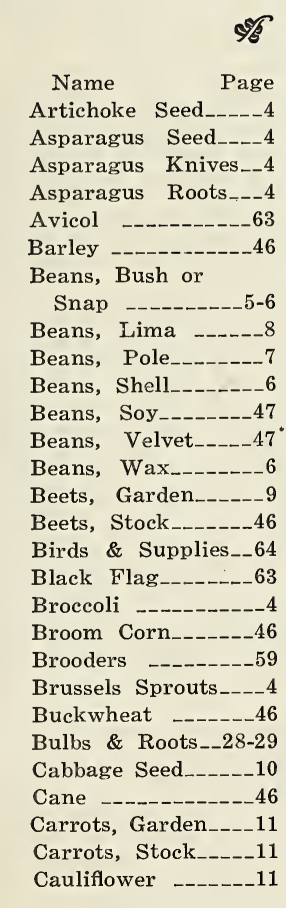

\section{N D E X}

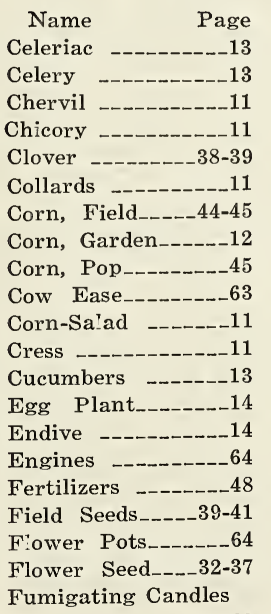

Fin

Gold Fish -

Gourds -.-------_28

Herbs ---.------ 28

Horse Radish Roots 14

Incubators _-_----- 60

Inoculants --_-_---48

Insecticides _-_._49-50

Feeds Inside Back Cover, and Insert Page 32
$\$ \%$

Name $\quad$ Page
Kale -
Kohlrabi --- ---_-14
Lawn Grass Seed

Name

Page

Potatoes, Irish_-_--_21

Poultry Remedies_32

Poultry Supplies 61-63

Pumpkin _-_-_-_--_22

Radish -_-_-_-_-_23

Raffia _._._._._._-_64

Rape, Dwarf

Essex -._-_-_-_46

Rat Poison_-__-_63

Rhubarb Roots_-_-_23

Rye -_-_._-_._._. 46

Salsify -----_--_23

Seed Sowers__-_-_-_42

Spinach -------24

Sprayers _-_-_51-52

Squash _--_-_-_----24

Stimuplant --_-_-_34

Sudan Grass_-_-_-_43

Swiss Chard__-_-_-_9

Thermometers -.-- 60

Tobacco --_-_-_26

Tomato Seed_-_-_25-26

Tools, Garden_--_53-57

Tools, Orchard_---_53

Trowels _-_-_-_-_59

Turnips --.--_-_-_27

Vetch ------------_45

Water Glass________63

Watering Pots_-_-_-_57 


\section{Monthly Calendar for Farmer and Gardener}

JANUARY-Vegetables-During this month little can be put in open ground except Asparagus, Rhubarb and Horse Radish Roots. Prepare hot beds and sow Early Cabbage, Lettuce, Radish, Beet, Cauliflower and Onion.

Flowers-Sow in open ground Sweet Peas (see directions for planting in this Catalogue); sow in hot beds, pansy, daisy, verbena, asters, and other flower seeds for later transplanting.

Farm-If weather permits, prepare the soil for crops to be put in in the spring. Top dress fall sown grain, grass and clover fields.

FEBRUARY - Vegetables-Sow in hot beds early cabbage, cauliflower, lettuce, onion, beets, and the middle or the last of the month in hot beds, tomatoes, egg plant and pepper. The last of this month sow in open ground early English peas, spring kale, beets spinach, carrots, radish and parsley. Set out asparagus horse radish and rhubarb roots, onion sets and hardy lettuce plants; also early planting of Irish potatoes can be made.

Flowers-Sow in open ground sweet peas (see directions in this book), in hot beds, boxes or pots inside; flower seed to be transplanted later. Sow the Grove Park Lawn Grass Seed, for making or repairing lawns.

Farm-Sow now Canada field peas and seed oats; also dwarf Essex rape an excellent quick deep grazing for sheep, hogs and poultry. From the middle to the last of this month grasses and clovers can safely be sown.

MARCH-Vegetables-This should be an active month with all vegetable growers. Sow in open ground garden peas for succession, early cabbage, cauliflower, spinach, kale, mustard, lettuce, beets, carrots, parsnips, salsify, early turnips, corn salad, rhubarb roots, asparagus and horse radish roots. Set out cabbage, cauliflower, lettuce and other plants that you have had in hot beds after hardening them by leaving the glass open at night. Pick a warm corner and sow herb seed.

Flowers-Sow in open ground sweet peas (see directions for planting). The hardy kind of flower seed, as they will bloom earlier. The last of this month set out tube rose, gladiolus, cannas and dahlia roots. Sow Grove Park Mixed Lawn Grass Seed.

Farm-Sow clovers and grasses of all kinds, winter and spring oats, dwarf Essex rape, Canada field peas, alone and with oats.

APRIL-Vegetables-Plant early garden corn, English peas, snap beans, early Irish potatoes, cabbage, tomatoes and lettuce in open ground for succession. Sow beets, carrots, radish, parsnips, salsify, parsley, celery, early turnips, kohlrabi, collards, corn salad, mustard and kale. Put out onion sets, asparagus roots, rhubarb roots, bed sweet potatoes. The middle to the last of this month plant cucumbers, squash, watermelons and cantaloupes. As all vine seeds are tender, care should be taken not to plant during cold, wet season.

Flowers-Sow hardy flower seed; after the middle of the month the half hardv kinds. Set out lily, dahlia, canna, tuberose and gladiolus bulbs, coleus, salvia and other bedding plants. Sow Grove Park Lawn Grass Seed.

Farm-Sow clover and grass seeds, spring seed oats early in the month. Later in the month sow mangel wurtzel stock beets, field corn, chufas, peanuts, artichokes, cotton etc.

MAY-Vegetables-Nearly all tender seeds can be sown this month; also for succession sow carrots, beets, parsley, radish, brussel sprouts, parsnips, salsify. Plant pole and bunch snap and lima beans, garden corn, okra, squash, cucumber, cantaloupe, watermelon and pumpkins. Sow now late cabbage and cauliflower seed to make plants for fall. Set out tomatoes, pepper, egg plants and strawberry plants.

Flowers-Vine seed for shade, all floral bedding plants. tuberose, gladiolus, cannas, dahlias and other bulbs can still be planted out successfully. Sow Grove Park Lawn Grass Seed.

Farm-All the sorghums, millets, cow peas, soy or soja beans, velvet beans, peanuts, chufas, tield corn, mangel wurzel beets for winter feeding, cotton, etc.

JUNE-Vegetables-Plant collards, okra, bunch and late pole snap and lima beans, black eye, white late peas, cucumbers, squash, turnips, gar- den corn; for succession, late potatoes, radish and beets. Set out tomatoes, cabbage, egg plants, pepper, cauliflower, celery, sweet potato plants.

Flowers-Nasturtiums and other flower seed for fall and winter use; vine seed for shade; coleus, salvia and other bedding plants.

Farm-Sow German millet, Sudan grass, sorghums, cow peas, soy beans, navy beans, velvet beans.' Plant late corn, pumpkins and watermelons.

JULY-Vegetables-Set out cabbage, collard and and celery plants for fall and winter use. Plant snap beans for succession, and sugar corn for late roasting ears. Sow rutabagas and early varieties of turnips, lettuce, mustard, collards, kohl-rabi. Plant cucumbers for pickling and table and late potatoes for winter use.

Flowers-Plant nasturtiums for late blooming; keep all plants well watered; use our sprinkler on your lawns.

Farm-Sow crimson clover at the last working of your corn or cotton. Buckwheat can be sown for bees, forage, an improver of the soil and grain. Sow cow peas, soy beans and velvet beans; these are improvers of the soil and fine hay crops; also for early hay or fodder sow German millet, Sudan grass and sorghums.

AUGUST-Vegetables-Sow cabbage and lettuce for fall heading, set out cabbage and celery plants continue planting snap beans for succession. Early English peas planted this month will give a good fall yield. Sow winter varieties radish, turnips, rutabagas, spinach, kale, mustard, endive, collards, parsley and onion seed.

Flowers-Make first planting of pansy and daisy seed. Keep all plants well watered.

Farm-Crimson clover should be sown in every available place. It is a great enricher of the soil and makes very nutritious feed. Rye and barley should be sown for fall and winter grazing and afterwards will make a crop of grain. Alfalfa can safely be sown. Towards the end of the month sow hairy vetch, dwarf Essex rape, grasses and clovers.

SEPTEMBER-Vegetables-Sow Winter radishes, spinach, turnips, mustard, leek, parsley, kale, extra early pearl and other onion sets.

Flowers-Hyacinths tulips, narcissus and other bulbs can be planted this month; also pansy seed. Sow Grove Park Mixed Lawn Grass Seed now. Farm-Sow all kinds of grasses and clovers and hairy vetch. Crimson clover should by all means be sown, as it makes the fine winter grazing and a great soil improver. Continue to sow winter rye and winter barley for early grazing crops as well as for grain; dwarf Essex rape for sheep and pigs. Winter oats this month get well rooted before spring.

OCTOBER-Vegetables-Sow early sorts of cabbage turnips, spinach kale mustard, collards set out all varieties of onion sets ; strawberry plants.

Flowers-Plant hyacinths, narcissus, tulips and other bulbs. Sow pansy seed for early spring plants. Fall seeding of a lawn does better than spring. Sow Grove Park Mixed Lawn Grass Seed, and fertilize with bone meal and sheep manure.

Farm-This is the month to sow wheat, winter oats, rye, barley, vetch and rape. The earlier you can get in your clovers and grasses the better.

NOVEMBER-Vegetables-Hot beds or cold frames should be made to sow lettuce and early varieties of cabbage; set out onion sets, asparagus roots, rhubarb and horse radish roots, strawberry plants.

Flowers-Hyacinths, tulips and other flowering bulbs should be planted. The Grove Park Mixed Lawn Grass Seed can be sown successfully; use bone meal and our pulverized sheep manure as fertilizers for lawns.

Farm-Sow rye on all vacant places; it makes a fine winter cover and grazing crop. Sow wheat, barley vetch, rape and grasses. Canada field peas. DECEMBER-Vegetables-In hot beds sow lettuce and cabbage. Beets and radish can be forced in hot beds for winter use as well as lettuce which often proves very profitable. Plant marrow fat peas for market or garden use.

Flowers-The early part of this month hyacinths and other bulbs can still be planted.

Farm-Canada field peas can be sown but should be sown deeper now. Wheat can still be sown. 


\section{Suggestions to Customers}

As to Ordering

DO NOT DELAY ORDERING until you are ready to use the goods you want. It will prove economical often to anticipate your wants. The loss of time in planting by delays of transportation companies, also advance in prices should show the wise buyer that it is to his interest to order early.

SAVE MONEY-When you make out your general list of seed, include insecticides and sprayers; also Fertilizers with your order, thereby you will save extra express charges. Remember, when the bugs or insects appear on your crop, you need insecticide; then delay in getting the remedy and sprayers may cost you ten times the cost of your purchase.

HOW TO SEND AN ORDER-You will find in the front and back of this book a pink order sheet, perforated for tearing out; also an addressed envelope to send the order in. When convenient, always use this order sheet. Please do not write anything on the sheet except items wanted and what pertains to the order. Write on seperate sheet asking for prices, or questions to be answered, or information given; this will avoid the possibility of being overlooked; also insure quick attention to information asked.

Please be careful to sign your name, post ofice, county and State on each order and letter sent us.

TERMS-All orders to secure prompt shipment should be accompanied with the cash. We can only send to well-rated merchants, or parties well known to us without the cash with order. When remittance falls short of amount of goods ordered, it is our custom to reduce the quantity sent, instead of delaying order by writing.

HOW TO SEND MONEY-By Postoffice or Express Money Order, Bank Check or Draft, cash by registered letter. We accept clean postage stamps for small amounts the same as cash.

C. O. D. ORDERS must be accompanied by a remittance equal to one-fourth the amount of the order; this insures the express or freight charges in case the goods are not taken when they arrive at destination.

POSTAGE ON SEEDS-We pay the Postage on packets, ounces and quarter-pound packages.

\begin{tabular}{|c|c|c|c|c|c|c|}
\hline \multicolumn{7}{|c|}{ Parcel Post Rates } \\
\hline $\begin{array}{l}\text { م } \\
\text { 号 } \\
\text { ○ } \\
\text { ○ }\end{array}$ & 馜 & 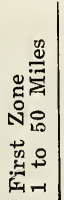 & 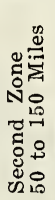 & 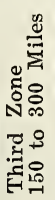 & 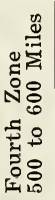 & 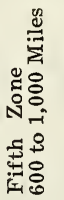 \\
\hline 1 & $\$ .05$ & $\$ .05$ & $\$ .05$ & $\$ .06$ & $\$ .07$ & $\$ .08$ \\
\hline & .06 & .06 & .06 & .08 & $\begin{array}{l}0.0 \\
.11\end{array}$ & .14 \\
\hline 3 & .06 & .07 & .07 & .10 & .15 & .20 \\
\hline 4 & .07 & .08 & .08 & .12 & .19 & .26 \\
\hline 5 & .07 & .09 & .09 & .14 & .2 & .32 \\
\hline 6 & .08 & .10 & .10 & .16 & .27 & .38 \\
\hline $7=$ & .08 & .11 & .11 & .18 & .3 & .44 \\
\hline & .0 & .12 & .12 & .20 & .3 & .5 \\
\hline 9 & .09 & .13 & .13 & .22 & .39 & .56 \\
\hline 10 & .10 & .14 & .14 & .24 & .4 & .62 \\
\hline & & .1 & .15 & .26 & .47 & .6 \\
\hline 12. & .11 & .16 & .16 & .28 & .51 & .74 \\
\hline & .11 & .17 & .17 & .30 & .55 & .80 \\
\hline & .12 & .18 & .18 & .32 & .5 & .86 \\
\hline & .12 & .19 & .19 & .34 & .6 & .92 \\
\hline & .13 & .20 & .20 & .36 & .6 & .98 \\
\hline & .13 & .21 & .21 & .38 & .71 & 1.04 \\
\hline & .14 & .22 & .22 & .40 & .7 & 1. \\
\hline 19 & .14 & .23 & .23 & .42 & .7 & 1.16 \\
\hline & .15 & .24 & .24 & .44 & .83 & 1.22 \\
\hline
\end{tabular}

IN LARGE QUANTITIES, see Parcel Post Rates in table given on this page.

PARCEL POST RATES ON MERCHANDISE AND SEEDS-Seed rate, 2 ozs. for one cent up to 8 ounces. Above 8 ounces local and zone Parcel Post rates are applied.

IMPORTANT NOTICE-All shipments of plants, bulbs and perishable stock are made at buyers' risk only. Under no circumstances will we ship perishable goods C. O. D. Cash must accompany orders.

If such goods arrive in bad condition, accept same from the transportation company and make claim for the loss. We will be glad to assist you in any way to collect the loss.

TRANSPORTATION CHARGES-Please bear in mind that we do not pay the parcel post, express or freight charges on pecks or bushels, nor on grass seeds, field seeds, poultry supplies or hardware, except where we so state on the pages where the goods are priced.

PRICES OF GRASS AND CLOVER SEEDS, SEED GRAYN and other field seeds are constantly fluctuating and are subject to market changes. The prices given in this Catalogue are those ruling at the time it is issued-about the first of January. As far as possible we will fill in full all orders for seeds that are quoted subject to variation in price, but if market values will not permit this, we will send all that money remitted will pay for.

Please Address All Orders and Correspondence to this Company to ASHEVILLE SEED COMPANY ASHEVILLE, NORTH CAROLINA NORTH CAROLINA DEPARTMENT OF AGRICULTURE, LICENSE NUMBER 452 


\section{High \\ Asparagus}

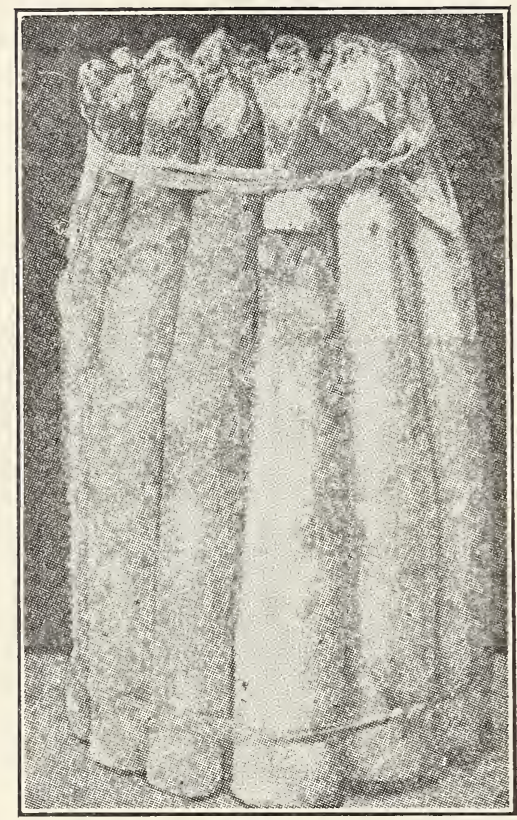

Asparagus

Asparagus grows well in practically any good soil, but a well enriched, deeply pulverized, sandy loam brings the best results. It may be grown from seeds or roots; by planting roots 1 to 2 years may be saved. A well cared for Asparagus bed improves with age and yields the first green delicacy for the table in large quantities each year. The home gardener should not be without a bed of this most delicious vegetable.

ROO'T CULTURE-The home gardener will find growing Asparagus from roots much easier, and cuttings may be had at least a year sooner. Prepare trenches $3 \mathrm{ft}$. apart and about 18 inches deep; fill with a liberal quantity of well rotted manure; after covering the manure with a few inches of dirt, set the plants $1 \frac{1 / 2}{2}$ feet apart in each trench; 4-inch covering of good soil is then added. Do not exhaust the plants by cutting too late, especially the first bearing season.

100 roots plant $15 \mathrm{ft}$. by $20 \mathrm{ft}$.

Culture of Seed-Sow the seed thinly in rows 1 foot apart in April or May. To secure strong healthy plants keep down all weeds and thin the poorest seedlings to 3 inches apart in each row. The roots may be dug either the first or second year in the fall after the plants die, and set either in the fall or spring, as described under "Root Culture."

PALMETTO ASPARAGUS-It is truly a very superior strain of Asparagus, being a more continuous and earlier bearer of uniformly large, thick, green shoots with a distinctly pointed tip. It is delicious in flavor, extremely tender, and an abundant yielder. Palmetto is well adapted for all sections of the country.

Postpaid-Pkt. 5c; oz. 10c; 1/4 1b. $30 \mathrm{c} ; 1$ tb. $90 \mathrm{c}$.

BARR'S MAMMOTH ASPARAGUS-The large stalks of Barr's Mammoth are sometimes an inch in diameter, and retain their thickness completely to the top and have close round heads. It is extremely hardy, quick growing, sweet and tender.

Postpaid-Pkt. 5c; oz. $10 \mathrm{c} ; 1 / 4 \mathrm{tb} .25 \mathrm{c} ; 1 \mathrm{~b}$. $75 \mathrm{c}$.

Price of roots given below in schedule.
Vegetable Seeds

CONOVER'S COLOSSAL-This variety is identical with the famous giant Argenteuil of France. It is a large stalked strain which has met with special favor on account of its thick, green stalks of excellent flavor and tenderness.

Postpaid-Pkt. 5c; oz. 10c; $1 / 4$ 1b. 25c; 1b. $75 \mathrm{c}$

Two-year-old Asparagus Roots will bear the first year; set in fall or spring.

Price list Asparagus Roots.

Palmetto, Barr's Mammoth, or Conover's Colossal. Postpaid-50 for 85c; 100 for $\$ 1.50$.

Express-50 for $75 \mathrm{c} ; 100$ for $\$ 1.25 ; 1 \mathrm{M}$ for $\$ 8.50$

\section{Asparagus Knives}

Fifteen inches long, blade $11 / 2$ inches wide. $50 \mathrm{c}$ each. If by mail, postpaid, $55 \mathrm{c}$ each.

\section{Green Globe Artichoke Seed}

The Green Globe Artichoke is cultivated for its flower heads, which are cooked like Asparagus. Sow the seed in hot beds during February and transplant in May into rows three feet apart and two feet in the rows. The seeds may be sown in the open during the month of April, and then the stand thinned. Artichoke requires a deep, rich, sandy loam with plenty of well rotted manure. When cold weather comes protect the plants with a heavy covering of leaves or manure. If properly cared for, the plants will bear for several years. An ounce plants 40 feet of drill.

Postpaid-Pkt. $10 \mathrm{c}$; oz. $75 \mathrm{c}$; 1/4 Ib. $\$ 2.50$.

\section{Broccoli}

Broccoli is hardier and easier to grow than Cauliflower. It is a delicious vegetable for boiling and is largely used for pickling. Cultivate like cabbage, setting the plants during June in rich soil. One ounce of seed produces 2,000 plants.

P U R P L E CAPE-An excellent large-headed variety.

Postpaid-Pkt. $5 \mathrm{c}$; oz. $35 \mathrm{c} ; 1 / 4$ tb. $\$ 1.25$; ib. $\$ 4.75$.

\section{Brussels Sprouts}

The sprouts resemble miniature cabbage, growing closely to stalk of the plant, being produced in abundance from the tip to the ground. Are extremely hardy and live through the winter without protection, frost improving the quality and flavor of the sprouts $\mathrm{wh} \mathrm{i} \mathrm{ch}$ are highly esteemed for boiling during late fall and winter months. Sow seed during $M$ a $y$ in drills when plants are 6 inche high, transplant into rows 3 feet apart and 18 inches apart in the row, and cultivate like cabbage.

\section{PERFECTION-}

Plants 2 feet tall, and stem thickly set with sprouts 2 inches in diameter<smiles>[194Sb]</smiles>

Brussels Sprouts.

Postpaid-Pkt. $5 \mathrm{c}$; oz. $20 \mathrm{c} ; .1 / 4$ Ib. $60 \mathrm{c}$; Ib. $\$ 2.10$

When ordering your garden seed, be sure to order the fertilizer best adapted for your garden. We would suggest that you give the land a good coating of ground limestone to sweeten the soil. See page 48 .

Be sure to order your insecticides with your general seed order. By spraying early and fiten you will save money and your crop. See page $49-50$. 


\section{DWARF OR BUSH (Snap) BEANS}

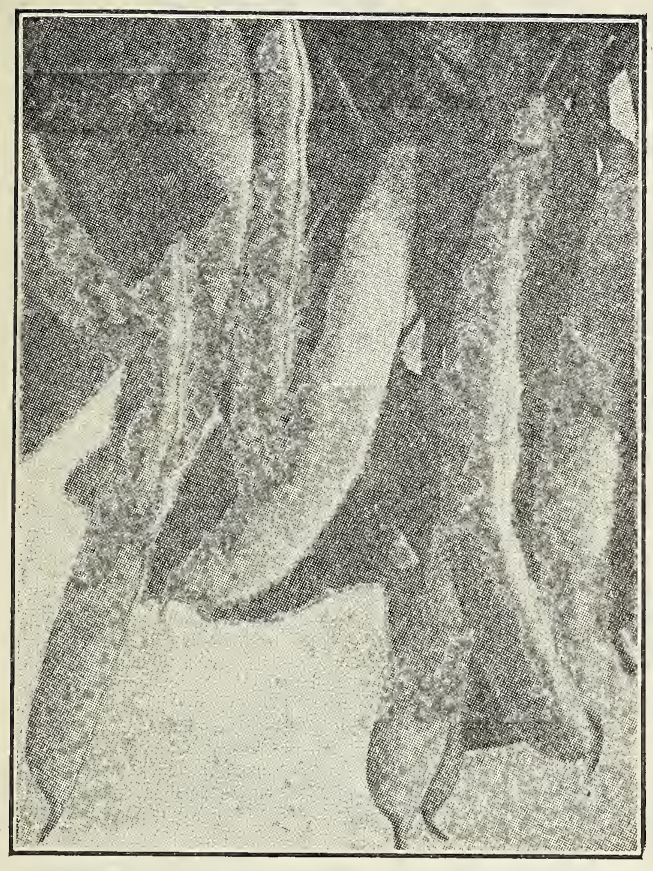

IMPROVED EARLY RED VALENTINE BEANS

One pound will plant 60 feet of drill; 100 pounds to an acre in drills.

Culture-Beans are very sensitive to both cold and wet. For the earliest crop, plant just as soon as the weather gets warm-in this section about the first of April. To have a succession, plant every two weeks throughout the summer until the middle of August. The largest returns will result from planting in drills from 2 to 3 feet apart, 3 to 5 inches apart in the row, covering about 2 inches deep; up to the time of blossoming they should have frequent shallow cultivation.

\section{Extra Early Red Valentine}

A standard variety, extra early in maturing, and bears pods which are round, long, slightly curved and of excellent quality. The extreme hardiness of this bean accounts for its popularity in this section as the first early bean. The Red Valentine germinates in co?d ground when other sorts fail. Our improved strain of this excellent variety has been selected especially for earliness and good quality.

Postpaid-Pkt. 10c; 1/2 1b. 20c; 1b. $35 \mathrm{c}$.

Express-Lb. 25c; 10 tbs. $\$ 2.00 ; 50$ tbs. $\$ 9.00$.

\section{Tennessee Green Pod}

This well known variety is almost as early as the Red Valentine. The productive plants bear handsome flat pods of light green color and excellent quality. Unlike most early beans, the quality remains good throughout its bearing season. The hardy and exceedingly prolific tendencies of the Tennessee Green Pod accounts for its popularity as early bunch beans.

Postpaid-Pkt. 10c; 1/2 tb. 20c; 1b. 35c.

Express-Lb. 25c; 10 tbs. $\$ 2.00 ; 50$ lbs. $\$ 9.00$.

\section{Burpee's Stringless Green Pod}

This famous and popular bean is still unequaled as an early stringless green pod variety. It is stringless, ripens earlier than the Valentine, and remains crisp and tender long after maturing. The vines bear long, round, thick and very meaty pods, entire:y free from strings. The attractive deep green color and unusual quality of these green pods has placed them in high favor. It has given entire satisfaction everywhere.

Postpaid-Pkt. 10c; 1/2 1b. 20c; ib. 35c.

Express-Lb. 25c; 10 tbs. $\$ 2.00$; 50 Ibs. $\$ 9.00$.

\section{Giant Stringless Green Pod}

A very large productive, long-podded variety, producing large pods, measuring 5 to 6 inches in length; very tender and absolutely stringless, and of the finest flavor; a splendid variety for the home gardener.

Postpaid-Pkt. 10c; 1/2 1b. 20c; 1b. 35c.

Express-Lb. 25c; 10 tbs. $\$ 2.00 ; 50$ ibs. $\$ 9.00$.

1 ib. equals about 1 pint.

2 tbs. equals about 1 quart.

5 ths. equals about $2 \frac{1}{2}$ quarts.

15 ths. equals one peck.

60 tbs. equals one bushel.

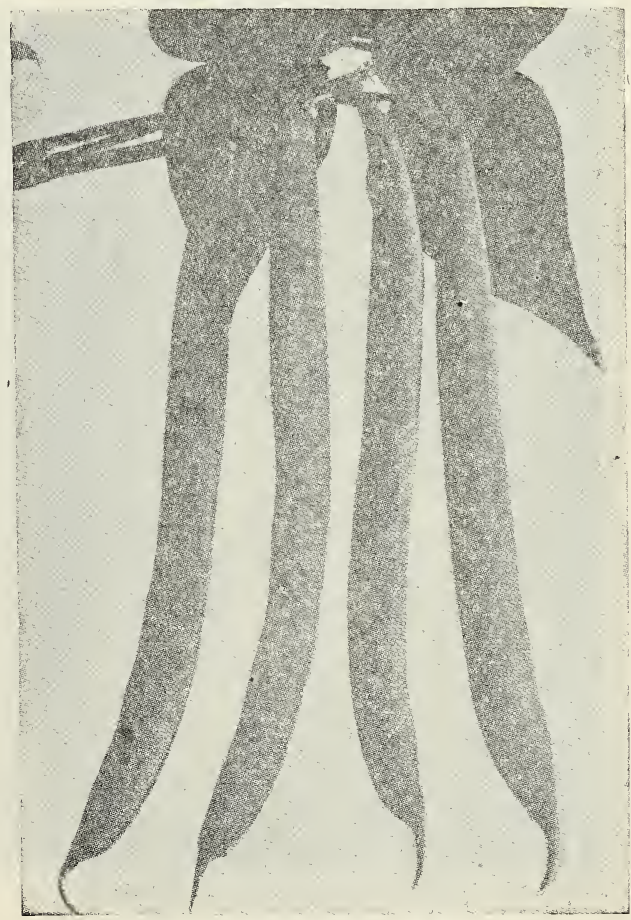




\section{Dwąrf or Bush Beans-Continued}

\section{Longfellow}

The prolific vines of Longfellow bear splendid green string beans. The pods are extra long, round, well formed and tender. This medium early variety is unexcelled for the home garden, the elegant appearing pods are delicious when cooked.

Postpaid-Pkt. $10 \mathrm{c}$; 1/2 1b. 20c; 1b. 30c.

Express-Lb. $25 \mathrm{c} ; 10 \mathrm{lbs}$. $\$ 2.00 ; 50$ 1b s. $\$ 9.00$.

\section{Black Valentine}

Produces an abundant crop of large pods which are straight, almost round and dark green. This is an excellent variety for the market on account of its handsome appearance.

Postpaid-Pkt. 10c; $1 / 2$ 1b. $20 \mathrm{c}$; 1b. $35 \mathrm{c}$.

Express-Lb. 25c; 10 1b s. $\$ 2.00 ; 50$ lbs. $\$ 9.00$.

\section{Refugee or $1,000-1$}

A medium late variety similar to the Valentine in general qualities, with round pods a third longer and tapering to a point.

Postpaid-Pkt. $10 \mathrm{c} ; 1 / 2$ 1b. $20 \mathrm{c}$; 1b. $35 \mathrm{c}$.

Express-Lb. $25 \mathrm{c} ; 10$ 1bs. $\$ 2.00 ; 50$ ibs. $\$ 9.00$.

\section{Bountiful}

A "long yellow six weeks" improved by earlier growth, hardiness and more prolific yield. Pods are large, flat, very tender, handsome, and free from strings. This variety may also be grown as a shell bean for winter use.

Postpaid-Plkt. 10c; $1 / 2$ 1b. $20 \mathrm{c}$; 1b. $35 \mathrm{c}$.

Express-Lb. $25 \mathrm{c} ; 10$ 1b s. $\$ 2.00$; 50 1bs. $\$ 9.00$.

\section{Fordhook Favorite Bush}

The bushes grow from 18 to 20 inches high, are vigorous, and remarkable for their prolific yield. The thick, round pods are at all stages brittle, juicy, free from tough fiber, entirely stringless.

Postpaid-Pkt. $10 \mathrm{c}$; $1 / 2$ 1b. $20 \mathrm{c}$; 1b. $35 \mathrm{c}$.

Express-Lb. $30 \mathrm{c} ; 10$ 1bs. $\$ 2.50$; 50 1bs. $\$ 11.00$.

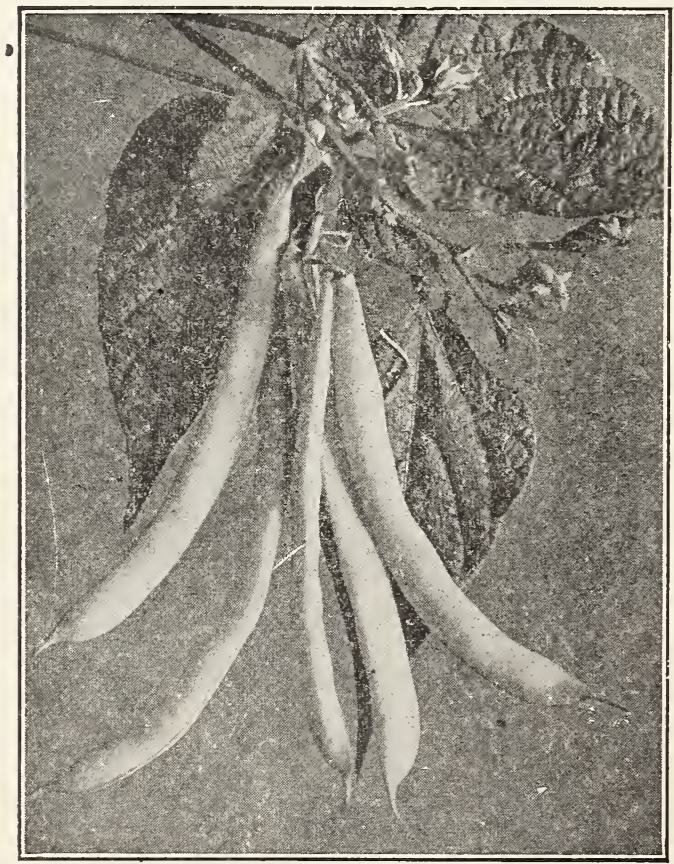

Dwarf Golden Wax Beans

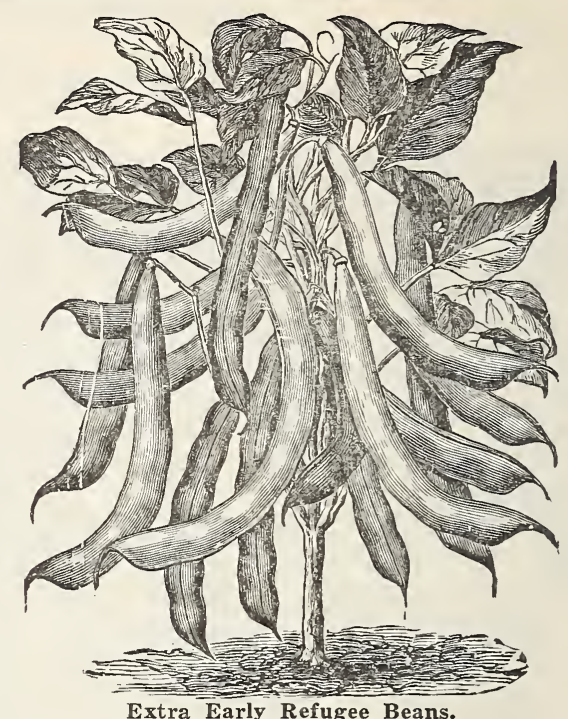

Shell Beans

These are grown exclusively to be used as shell beans, either green or dried for winter. Plant them in vacant places in your garden; they are always useful.

IMPROVED WHITE KIDNEY-A most eXcellent white, kidney-shaped field bean.

Postpaid-Pkt. $10 \mathrm{c} ; 1 / 2$ tb. $20 \mathrm{c}$; th. $30 \mathrm{c}$.

Express-Lb. $25 \mathrm{c}$; 10 1bs. $\$ 2.00$; 50 1bs. $\$ 9.00$.

RED KIDNEY - A vigorous grower and very productive. These large red kidney-shaped beans are extensively used as shell beans.

Postpaid-Pkt. 10c;1/2 tb. 20c; ib. 30c.

Express-Lb. $25 \mathrm{c} ; 10 \mathrm{lbs}$. $\$ 2.00 ; 50$ 1bs. $\$ 9.00$.

WHITE NAVY BEANS-It is the most popular bean grown for market, and at the same time one of the most profitable. We strongly recommend planting a larger acreage in this section.

Postpaid-Pkt. 10c; $1 / 2$ lb. $20 \mathrm{c}$; 1b. $30 \mathrm{c}$ Express-Lb. 25c; 10 Ibs. $\$ 2.00$. 50 tbs. $\$ 8.50$

LARGE WHITE MARROW-Large ovalshaped white beans, grown as a field crop for baking.

Postpaid-Pkt. 10c; $1 /$ ib. 20c; ib. $35 \mathrm{c}$

Express-1b. $25 \mathrm{c} ; 10 \mathrm{lb}$. $\$ 2.00$.

\section{Wax Podded Bush Beans}

DAVIS KIDNEY WAX - The vigorous vines are very prolific, bearing waxy white pods 7 inches long; the Davis Kidney Wax is the finest appearing of all early wax beans. The White Kidney shaped beans make splendid shell beans for baking but when grown for snap beans in the home garden they should be used while young and free from strings.

Postpaid-Pkt. 10c; $1 / 2$ tb. $20 \mathrm{c}$; 1b. $35 \mathrm{c}$

Express-Lb. $25 \mathrm{c} ; \quad 10$ Ibs. $\$ 2.00$; 50 tbs. $\$ 9.00$

DWARF GOLDEN WAX-For a number of years this variety has been popular with the home gardeners. The attractive golden yellow pods are fleshy, semi-round, long, and of fine quality. The matured beans are excellent for winter use as shell beans.

Postpaid-Pkt. 10c; $1 / 2$ tb. 20c; lb. 35c.

Express-Lb. 25c; 10 lbs. $\$ 2.00$. 50 lbs. $\$ 9.00$.

DWARF BLACK WAX - One of the earliest wax podded varieties. Pods are 4 to 5 inches long; round, meaty, brittle and stringless, golden yellow, of excellent flavor; very prolific.

Postpaid-Pkt. 10c; $1 / 2$ 1b. $20 \mathrm{c}$; 1b. $35 \mathrm{c}$.

Express-Lb. 25c; 10 tbs. $\$ 2.00$; 50 lbs. $\$ 9.00$. 


\section{Pole or Cornfield Beans}

Cultrure-Pole Beans are not so hardy as bunch beans, and in this latitude plant about the first of May or after the danger from frost is over, in rows 4 feet apart; set poles 6 to 8 feet long, 3 to 4 feet apart in the row; drop 5 to 6 beans 2 inches deep around each pole or hill. These varieties may also be planted in the cornfield to run up the stalk.

Cornfield beans are much more troublesome to grow than bush beans, but it pays better to grow them as the beans are of a much better quality and they bear longer and more profusely.

We handle only the better varieties of these beans and those best adapted to this locality.

One pound will plant 100 hills; 30 pounds to acre.

WHITE KENTUCKY WONDER (BURGER'S STRINGLESS GREEN POD)-The pods are borne in clusters, are uniformly straight, meaty, entirely stringless, tender, of mild flavor. The pearly white beans make splendid dry beans.

Postpaid-Pkt. 10c; $1 / 2$ lb. 20c; tb. $35 \mathrm{c}$.

Express-Lb. $30 \mathrm{c} ; 10$ tbs. $\$ 2.75$.

KENTUCKY WONDER or OLD HOMESTEAD - The most popular of the pole green-podded snap beans. The long pods, often 9 to 10 inches in length, are borne in large clusters; pods are nearly round, fleshy, stringless and very showy; an early and most prolific variety.

Postpaid-Pkt. 10c; $1 / 2$ lb. 20c; tb. $35 \mathrm{c}$.

Express-Lb. $30 \mathrm{c} ; 10$ lbs. $\$ 2.75$

LAZY WIFE-A superior variety for home gardens, Also as a field bean among corn Has large, green, very tender pods of delicious flavor. They are broad and thick, and are stringless until quite large. Very desirable for cooking in the pod or as a shell bean. The dried beans are round, pure white.

Postpaid-Pkt. $10 \mathrm{c}$; $1 / 2$ tb. $20 \mathrm{c}$; to. $35 \mathrm{c}$.

Express-Lb. $30 \mathrm{c} ; 10$ tbs. $\$ 2.75$

STRIPED CREASEBACK POLE OR CORN FIELD-Very early, yet bears for a long season. The rich dark green pods borne in clusters are 6 to 8 inches long, of excellent flavor, tender and stringless. Very popular for growing in corn.

Postpaid-Pkt. 10c; $1 / 2$ tb. 20c; tb. $35 \mathrm{c}$.

Express-Lb. $30 \mathrm{c} ; 10$ tbs. $\$ 2.75$

WHITE CREASEBACK-Extremely early, very productive. Pods are borne in clusters from 4 to 6 inches in length; broad, thick, solid, fleshy and stringless. Well adapted for shipping to distant markets.

Postpaid-Pkt. 10c; $1 / 2$ tb. $20 \mathrm{c}$; th. $35 \mathrm{c}$.

Express-Lb. $30 \mathrm{c} ; 10$ tbs. $\$ 2.50$.

OCTOBER, Or HORTICULTURAL (WREN'S EGG, or CRANBERRY) - Pods short, broad, pale green, streaked with bright red as they mature. Beans are large, oval, flesh-colored, splashed and spotted with wine red and of the highest quality, either green or dry. Many like this variety better than the Limas. Especially adapted for mountainous districts, short seasons and cool locations.

Postpaid-Pkt. 10c; $1 / 2$ ib. 20c; 1b. $35 \mathrm{c}$.

Express-Lb. $30 \mathrm{c} ; 10$ ibs. $\$ 2.75$.

CU'T SHORT, or CORN HILL-An old variety very popular for planting among corn, and it will give a good crop without use of poles; vines medium, pods short, cylindrical and white, covered at one end with reddish brown dots.

Postpaid-Pkt. $10 \mathrm{c}$; $1 / 2$ 1b. 20c; 1b. 35c.

Express-Lb. $30 \mathrm{c} ; 10$ tbs. $\$ 2.75$.

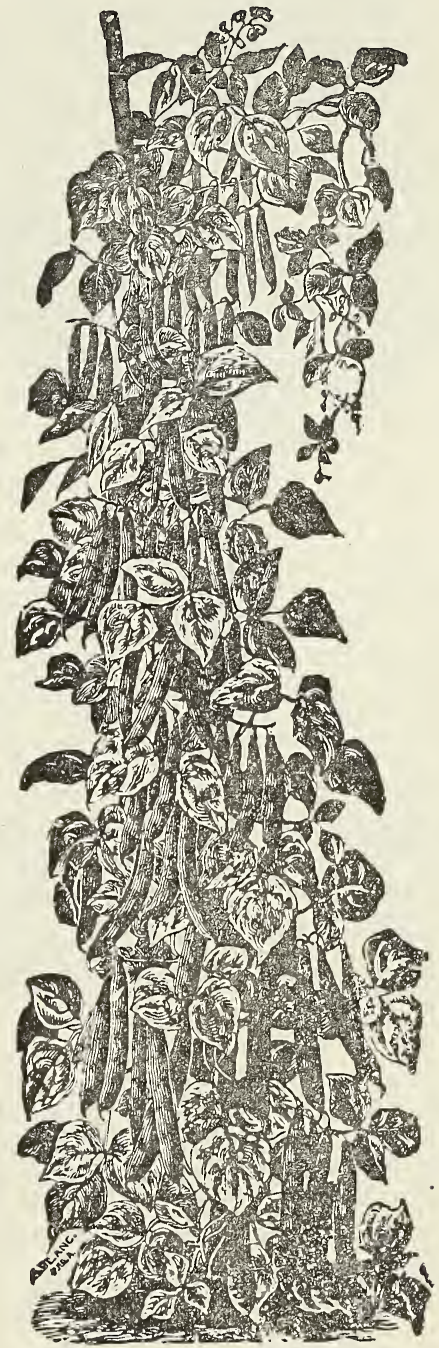

Kentucky Wonder Pole Beans.

WHITE DUTCH CASE KNIFE-Green snap pods 7 to 8 inches in length. Very straight and flat, stringy, brittle and of good quality; midseason, best as a shell bean. Beans very flat and ivory white.

Postpaid-Pkt. 10c; $1 / 2$ tb. $20 \mathrm{c}$; ib. $35 \mathrm{c}$.

Express-Lb. 30c; 10 1bs. $\$ 2.75$.

EARLY GOLDEN CLUSTER WAX-The grandest yellow-podded Pole Bean in cultivation. Pods are produced in clusters of from 4 to 6 inches long the entire length of the vines, and are fit for use a long time after reaching maturity.

Postpaid-Pkt. $10 \mathrm{c} ; 1 / 2$ tb. 20c; 1b. $35 \mathrm{c}$.

Express-Lb. $30 \mathrm{c} ; 10$ tbs. $\$ 2.75$. 


\section{Select Lima Beans}

\section{PLANT MORE LIMA BEANS FOR BOILING, BAKING AND CANNING.}

While Lima Beans are rapidly growing in popularity, this excellent table food is still not grown so extensively as it merits. Lima Beans have a rich and delicate flavor that is not found in other types of beans, and for this reason are unexcelled for baking, boiling, or canning. They are largely used as green beans cooked either alone or with sugar corn. As a dried bean they keer as well as other types in any climate and are more nutritious food than the latter.

No Lima Beans should be planted until the ground is warm and all danger of frost is over. The germination of practically all limas is not as high as ordinary beans, hence a liberal planting is necessary and cheaper in the end.

\section{Dwarf or Bush Lima Beans}

Bush Limas are planted for early crop, since they come into bearing much sooner than pole varieties. The dwarf varieties are not as prolific as the pole lima beans, but they produce a good crop of equal quality and are not so difficult to grow; always plant the eyes down dropping 3 beans 15 inches apart in rows 3 feet apart. The beans should be covered from $1 \frac{1 / 2}{2}$ to 2 inches deep. One pound will plant 60 hills, 60 pounds to the acre.

"BURPEE'S IMPROVED BUSH LIMA"-The pods are truly enormous in size, borne abundantly and well-filled with handsome beans which are both larger and thicker than those of the popular Burpee's Bush, and fully 8 days earlier. The bushes when full grown are 30 inches high and 24 inches in diameter. The beautiful pods measure 5 to 6 inches long and are borne in clusters of 4 or 5 pods. The beans are of first quality.

Postpaid-Pkt. 10c; $1 / 2$ 1b. 25c; 1b. 45c.

Express-Lb. $40 \mathrm{c} ; 10$ 1bs. $\$ 3.50$.

FORDHOOK BUSH LIMA-This is without a doubt the best type of bush lima bean in cultivation. It grows upright and does not come in contact with ground. The vigorous plants bear pods in clusters, each pod containing 4 to 5 large, thick beautiful green beans. No other variety can compare in quality with the sweet and tender Fordhook. Matures very early and continues bearing until frost.

Postpaid-Pkt. 10c; 1/2 1b. 25c; 1b. 45c.

Express-Lb. $40 \mathrm{c} ; 10$ 1bs. $\$ 3.75$.

HENDERSON'S BUSH LIMA-Pods short and flat, delicious flavor. The earliest of bush limas two weeks earlier than any of the pole varieties. It is small in size, but the great productiveness and delicious flavor of Henderson's Bush Limas has made it a favorite of good housekeepers. An excellent sort for canning.

One pound will plant 100 hills; 30 pounds to the acre.

Postpaid-Pkt. 10c; 1/2 1b. 20c; 1b. 35c.

Express-Lb. $30 \mathrm{c} ; 10$ 1bs. $\$ 2.75$.

All prices in this catalogue are subject to change without notice. Orders will be filled at lowest prevailing price the day received.

\section{Tall or Pole Lima Beans}

Plant 3 or 4 beans to the hills 3 feet apart in 3 or 4 foot rows. It is necessary to provide poles 6 to 8 feet long for each hill. The beans will make a very rapid growth if a small shovel full of well rotted cow manure is added to each hil when the poles are set. All pole limas are exceedingly prolific and are preferred by truck garden ers. One pound will plant 60 hills; 60 pounds to the acre.

KING OF THE GARDEN POLE LIMA-An improved strain of large white, of more prolific character and with larger pods and beans. Large eariy crops and bears until frost. Only two plants should be allowed to one hill.

Postpaid-Pkt. $10 \mathrm{c} ; 1 / 2$ 1b. $25 \mathrm{c}$; 1b. $45 \mathrm{c}$.

Express-Lb, 40c; 10 tbs, $\$ 3.50$.

CARPENTERIA LIMA, L A R G E GREEN SEEDED-This is the highest standard in pole lima quality ; many expert growers claim that Carpenteria is "the most perfect pole lima bean." The exceptionally fine quality of this strain is shown in the beautiful green tint of the large, handsome beans which fill the rich colored and attractive pods. The velvety green tint remains long after the bean becomes dry, which proves that the exceptional quality endures. Our strain of Carpenteria produces strong vigorous vines which send out many runners to bear great quantities of elegant pods, each containing four large beans. The beans are thin skinned, extremely tender and of fine flavor.

Postpaid-Pkt. 10c; $1 / 2$ tb. 25c; 1b. $45 \mathrm{c}$.

Express-Lb. $40 \mathrm{c} ; 10$ tbs, $\$ 3.50$.

FORD'S MAMMOTH PODDED - One of the largest podded and heaviest cropper of all pol limas. The vines are vigorous growers and bear enormous pods filled with four and sometimes five beans of rare flavor and quality. It matures early and bears until frost.

Postpaid-Pkt. 10c; 1/2 tb. 25c; 1b. 45c.

Express-Lb. $40 \mathrm{c} ; 10$ tbs. $\$ 3.50$.

CAROLINA SEIVA or SMALL SEEDED POLE LIMA, "The Butter Bean of the South"-These grow quickly, mature early, and are extremely prolific. The beans are small and white, on the order of Henderson's Bush Lima. They make a dried bean of superior merit.

One pound will plant 100 hills; 30 pounds to the acre.

Postpaid-Pkt 10c; 1/ 1b. 25c; 16. 40c.

Express-Lb. $35 \mathrm{c} ; 10$ 1bs. $\$ 3.25$.

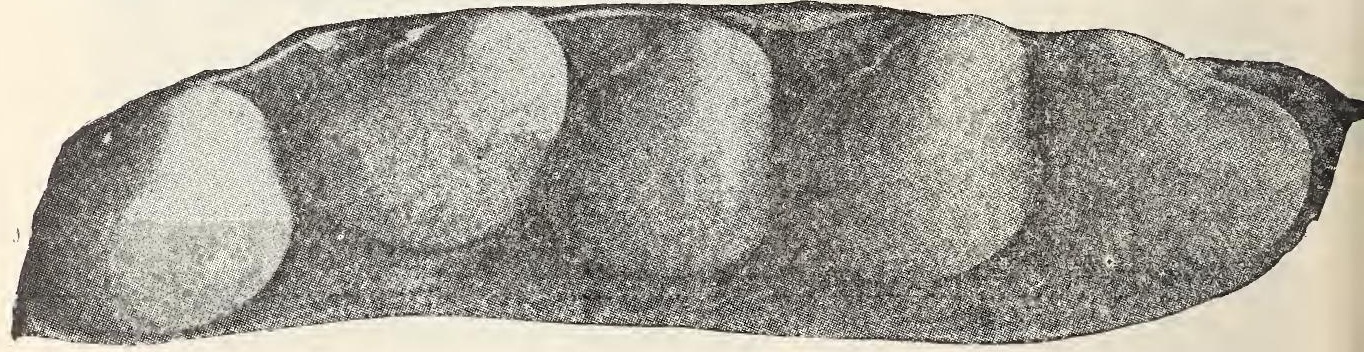




\section{Garden or Table Beets}

Culture-Beets thrive best in rather light, mellow and deep-worked soil, which has been thoroughly enriched with well-rotted manure or fertilizer, which should be well mixed with soil. Sow in drills 2 feet apart and thin out the plants to 4 inches apart in the drills. For a small garden the drills need not be more than 12 to 15 inches apart.

One ounce will sow 50 feet of drill, 6 to $81 \mathrm{bs}$. to the acre.

EARLY RED BALL BEETS-This variety has proven to be the best red turnip beet not only for the maket gardener, but for home use. It is also by far the best for canning, making a strikingly handsome product, much superior to that obtained from any other sort. Root globular and very smooth; color of skin dark blood red; flesh deep red, very crisp, tender and sweet, and remaining so for a long time.

Postpaid-Pkt. 10c; oz. 15c; 1/4 lb. 40c; 1b. $\$ 1.25$.

CROSBY'S IMPROVED EGYPTIAN - An improvement on other Egyptian sorts, being as early, and of more desirable shape, color and quality. Is being more largely planted for early market, by truckers and shippers, and has proven very profitable and satisfactory, being very sweet and tender.

Postpaid-Pkt. $5 \mathrm{c}$; oz. $10 \mathrm{c} ; 1 / 4$ 1b. $30 \mathrm{c}$; 1b. $\$ 1.00$.

DETROIT DARK RED TURNIP-A very fine strain of turnip-shaped beet. Top small, upright growing, thus permitting close planting. Color of skin dark blood red; flesh bright red. Quality is of the very best, sweet, tender, and lasting.

Postpaid-Pkt. $5 \mathrm{c}$; oz. $10 \mathrm{c} ; 1 / 4$ 1b. $30 \mathrm{c} ; 1 \mathrm{~b} . \$ 1.00$.

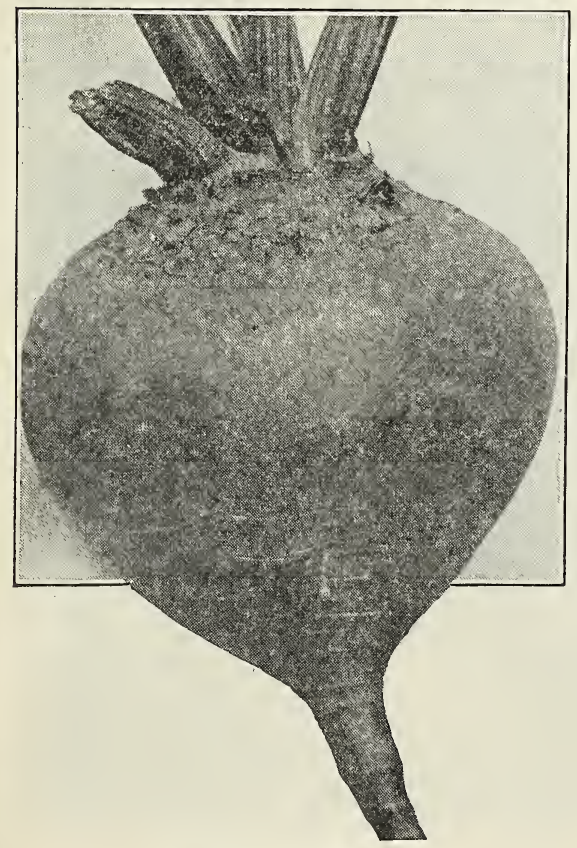

DETROIT DARK RED

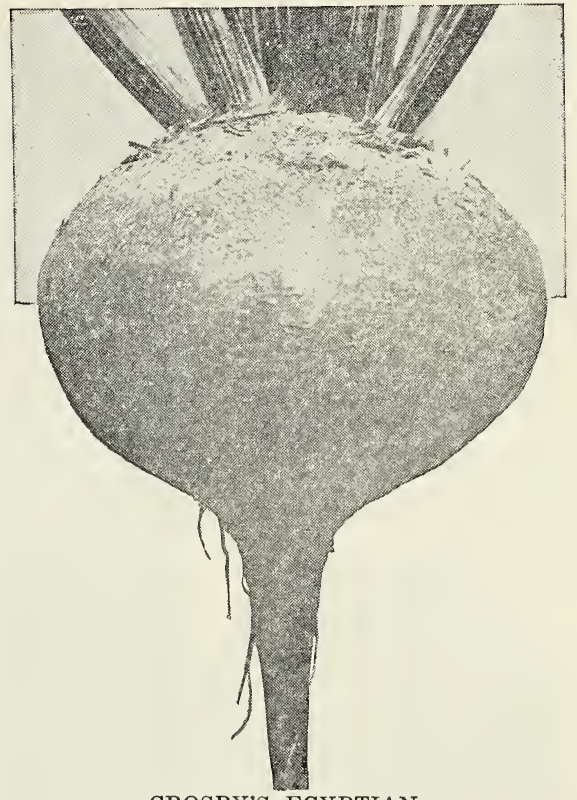

CROSBY'S EGYPTIAN.

IMPROVED EARLY BLOOD TURNIP - A superior selection of Blood Turnip Beet. Dark red, fine flavor. It forms medium-sized, sound, half-flattened bulbs. Good for late or early planting.

Postpaid-Pkt. $5 \mathrm{c}$; oz. $10 \mathrm{c} ; 1 / 4$ 1b. $30 \mathrm{c} ; 1 \mathrm{~b} . \$ 1.00$.

CRIMSON GLOBE-The interior is a rich, deep crimson, and fine grained in texture. The foliage is deep blood red. It is nearly round, of medium size, and does not become coarse at maturity.

Postpaid-Pkt. 5c; oz. 10c; 1/4 1b. 30c; 1b. $\$ 1.00$.

EXTRA EARLY ECLIPSE-A very early maturing Beet, especially desirable for the home garden. Top of medium size. Root nearly globular, with a small tap root and small collar. Flesh bright, red, very sweet, crisp and tender.

Postpaid-Pkt. $5 \mathrm{c}$; oz. $10 \mathrm{c} ; 1 / 4$ tb. $35 \mathrm{c} ;$ lb. $\$ 1.10$.

EDMAND'S BLOOD TURNIP-This beet is an excellent keeper. They are nearly round and smooth. Skin and flesh deep red; crisp and sweet. A desirable sort to plant late for winter use.

Postpaid-Pkt. $5 \mathrm{c}$; oz. $10 \mathrm{c}$; $1 / 4$ 1b. $30 \mathrm{c}$; 1b. $\$ 1.00$.

\section{Spinach Beet, or Swiss Chard}

The stalks when cooked and served like asparagus make a most delicious salad. The leaves should be prepared like spinach, kale or turnip salad. Sown early in the spring, it yields salad all summer. Grow a row and you will not be without it hereafter.

\section{Swiss Chard Lucullus}

The stalks are as thick and broad as rhubarb, heavily ribbed and from 10 to 12 inches long below the leaf. The large leaves are thick and heavily crumpled and of fine flavor.

Postpaid-Pkt. $5 \mathrm{c}$; oz. $10 \mathrm{c} ; 1 / 4$ 1b. $30 \mathrm{c} ; 1 \mathrm{tb} . \$ 1.00$.

Stock Beets-Page 46. 


\section{High Quality Cabbage Seed}

SELECT EARLY JERSEY WAKEFIELD-This sharp head variety is very early, compact leaves; its hardiness enables it to resist all sorts of unfavorable conditions. Has for a long time been the market gardener's favorite for a first early cabbage.

Postpaid-Pkt. $5 \mathrm{c} ;$ oz. $20 \mathrm{c} ; 1 / 4$ tb. $70 \mathrm{c} ;$ lb. $\$ 2.60$.

CHARLESTON or LARGE WAKEFIELD-Ripens few days later than the Jersey, but much larger, and possesses all the blood qualities of the True Wakefield type in an intensified degree.

Postpaid-Pkt. $5 \mathrm{c}$; oz. $20 \mathrm{c} ; 1 / 4$ ib. $70 \mathrm{c}$; 1b. $\$ 2.60$.

LONG ISLAND EARLY FLAT DUTCH-Heads are large and solid, and mature very early-just after the select Jersey Wakefield, and may be marketed at the same time with Wakefield. In every respect it is a cabbage worthy of cultivation.

Postpaid-Pkt. $5 \mathrm{c}$; oz. $20 \mathrm{c} ; 1 / 4$ 1b. $70 \mathrm{c} ; 1 \mathrm{~b}$. $\$ 2.50$.

HENDERSON'S EARLY SUMMER-This is an ideal second early sort. It forms flattish solid heads averaging about 8 to 10 tbs. Our seed is very carefully selected.

Postpaid-Pkt. 5c; oz. $20 \mathrm{c} ; 1 / 4$ Ib. $70 \mathrm{c} ; 1 \mathrm{~b} . \$ 2.60$.

ALLHEAD EARLY - For uniformity, reliability of heading, size, earliness and quality it is very superior. Its heads grow compact and free from spreading leaves.

Postpaid-Pkt. $5 \mathrm{c}$; oz. $20 \mathrm{c} ; 1 / 4$ 1b. $70 \mathrm{c}$; ib. $\$ 2.60$.

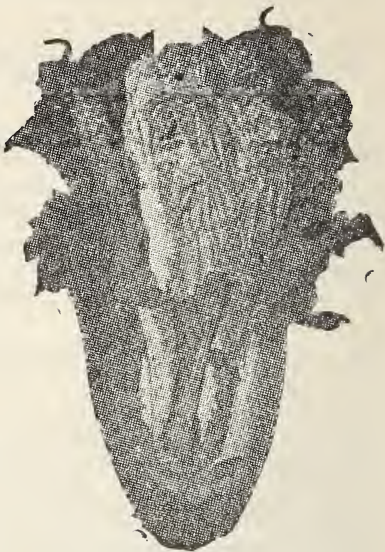

PE-TSAI CHINESE,

OR CELERY CABBAGE

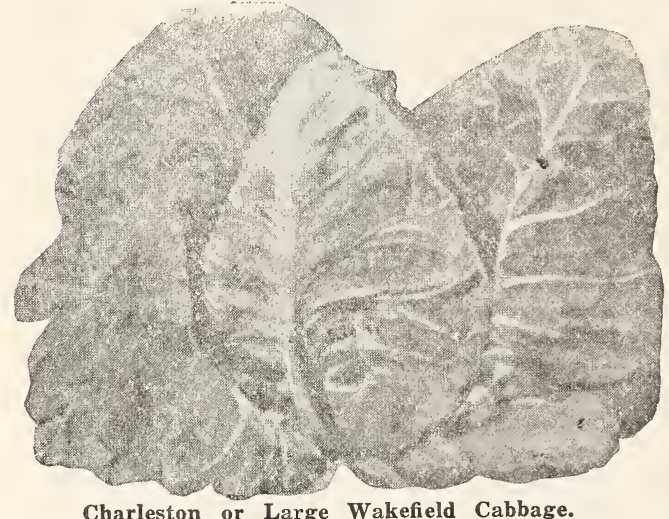

Charleston or Large Wakefield Cabbage.

often weighing $10 \mathrm{lbs}$. Leaves being tightly folded allows close planting. It produces a fine grain, tender, white head of excellent quality.

Postpaid-Pkt. $5 \mathrm{c} ;$ oz. $40 \mathrm{c} ; 1 / 4 \mathrm{tb} . \$ 1.35 ; \mathrm{lb} . \$ 5.00$. CHINESE PE-TSAI or "CELERY" CABBAGE -Produces beautiful crisp, celery-like heads that blanch easily and that resemble a giant Cos lettuce. As a salad it rivals the finest lettuce, when cooked as cabbage or spinach it makes delightful greens. Its pure white heads make the best cold slaw. It is easily grown, but should be planted early, as it does best during the cool season.

Postpaid-Pkt. 5c; oz. $25 \mathrm{c} ; 1 / 4$ 1b. $70 \mathrm{c} ;$ tb. $\$ 2.60$.

DANISH BALL HEAD-This sort is also known and sold as Hollander; the two varieties are identical. One of the hardiest of all late sorts; stands cold and drought; produces a hard, compact, medium sized, perfectly round head of the finest quality. A sple indid keeper and shipper.

Postpaid-Pkt. 5c; oz. $30 \mathrm{c} ; 1 / 4$ 1b. $85 \mathrm{c}$; Ib. $\$ 3.00$.

AMERICAN DRUMHEAD SAVOY-The hardiest cabbage in cultivation. Heavy frosts only improve the quality.

Postpaid-Pkt. 5c; oz. 20c; $1 / 4$ tb. $70 \mathrm{c}$; Ib. $\$ 2.50$. MAMMOTH RED ROCK-The largest and hardEARLY SHORT STEM-DRUMHEADIt is ready for marketing 2 or 3 weeks earlier than the late Drumheads, forms large, solid, rounded heads weighing from 15 to 25 pounds.

Postpaid-Pkt. 5c; oz. $20 \mathrm{c} ; 1 / 4$ Ib. $70 \mathrm{c}$; 1b. $\$ 2.50$.

HENDERSON'S EARLY SUCCESSION-A wonderful cabbage for solidity, productiveness and fine large heads. Matures early, has handsome color and fine quality.

Postpaid-Pkt. $5 \mathrm{c}$; oz. $20 \mathrm{c} ; 1 / 4$ Ib. $70 \mathrm{c}$; ib. $\$ 2.50$.

LARGE LATE DRUMHEAD - Very hardy and desirable fall and winter abbage. Head enormous. A good keeper and shipper.

Postpaid-Pkt. $5 \mathrm{c}$; oz. $20 \mathrm{c} ; 1 / 4$ tb. $70 \mathrm{c}$; ib. $\$ 2.50$

SELECTED LATE FLAT DUTCHGrown very extensively by market gardeners for late crop. It grows very large, a sure header, uniform in shape, size and color. Large leaved and short stem.

Postpaid-Pkt. 5c; oz. 20c; $1 / 4$ Ib. $70 \mathrm{c}$; ib. $\$ 2.50$

COPENHAGEN MARKET - As early as the Jersey Wakefield, and yields heavier crop. For a round head variety, this seems to be a strong statement. It is a fact and proven so by gardeners all over America for five years. Some of its chief features, in addition to its earliness, are its compactness, its light green leaves tightly folded, large size of heads iest heading sort; large leaves, deep red color; very fine.

Postpaid-Pkt. 5c; oz. 20 c ; 1/4 tb. 70 c ; tb. $\$ 2.50$.

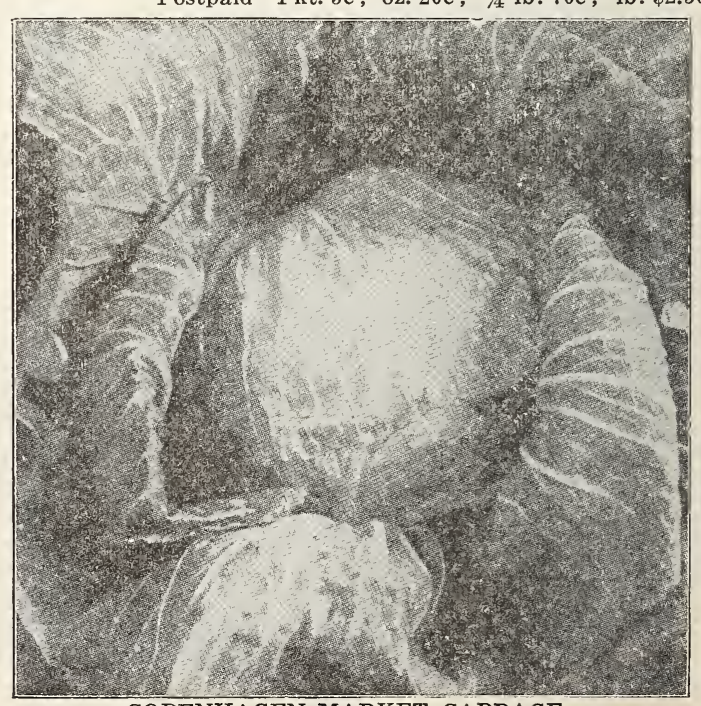

COPENHAGEN MARKET CABBAGE 


\section{Carrots}

One ounce is enough to sow 100 feet of drill. Four to five pounds is enough to plant an acre.

DANVER'S HALF LONG-This is the most popof this favorite sort, which shows its shape. A great yielder; short top, coarse leaves; roots smooth, of fine sweet flavor; color rich orange red.

Postpaid-Pkt. 5c; oz. $10 \mathrm{c} ; 1 / 4$ lb. $30 \mathrm{c} ; 1 \mathrm{~b} . \$ 1.10$.

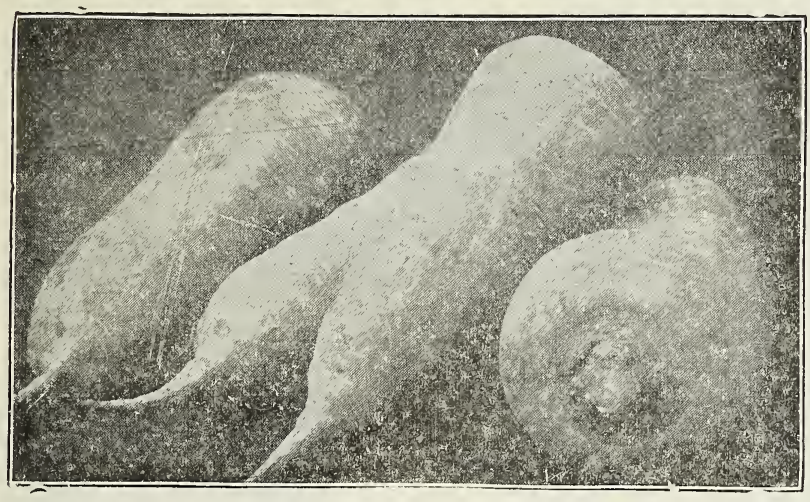

DANVER'S HALF LONG CARROTS 1b. $\$ 1.00$. ular sort for all purposes. We illustrate a bunch

\section{Corn Salad or Fetticus}

Sown with the approach of cool weather in the fall, it will produce an abundance of leaves which may be used as a salad throughout winter and spring. Quite hardy, but should be protected during severe weather. One ounce will sow 20 square feet. Large seeded.

Postpaid-Pkt. 5c; oz 10c; 1/4 tb. $30 \mathrm{c}$;

\section{Cauliflower}

One-fourth ounce produces about 500 plants; 3 ounces make enough to set out an acre. $\mathrm{Ma}$ tures heads in 90 days from planting.

Cauliflower succeeds well in any soil where cabbages grow. It delights in a rich soil and plenty of water. Early planting is essential; in this section plant in hot-beds in February, March and early in April; also rapid and thorough cultivation. Transplanting should be lone in moist weather.

EARLY SNOWBALL - This variety is not only the earliest to head but a remarkably sure header, making large, solid. header, making large, solid,
perfect, pure white heads of
Our seed imported direct from the finest quality. Our seed imported

Postpaid-Pkt. 15c; $1 / 4$ oz. $60 \mathrm{c} ;$ oz. $\$ 2 ; 1 / 4$ ib. $\$ 7.50$.

DRY WEATHER CAULIFLOWER-This new cauliflower is especially adapted for growing in dry locations when other varieties fail. It pro. dry locations when other
duces large, solid heads.

Postpaid-Pkt. 10c; 1/4 oz. $50 \mathrm{c} ;$ oz. $\$ 1.75$ : $1 / 4$ 1b. $\$ 6.50$.

EXTRA EARLY ERFURT-An extra early compact sort, pure white, a reliable header, and suitable for both outdoor and forcing.

Postpaid-Pkt. $10 \mathrm{c} ; \quad 1 / 4$ oz. $50 ;$ oz. $\$ 1.7 \mathrm{j}$; $1 / 4$ 1b. $\$ 6.50$.

See page 31 for prices of Cauliflower plants.

\section{Collards}

tump rooted sort; best for thin soil and heavy land; fine grained and very sweet.

Postpaid-Pkt. 5c; oz. $10 \mathrm{c} ; 1 / 4$ 1b. $30 \mathrm{c} ; 1 \mathrm{~b} . \$ 1.10$.

\section{CARROTS FOR STOCK FEEDING}

Carrots are full of starch and sugar, furnishing very nutritious and wholesome feed; they are easily grown. In the South their hardiness and ease of cultivation make them very porfitable.

IMPROVED WHITE BELGIAN-Grows onethird above ground. Root pure white, green above ground with small top; flesh rather coarse.

Postpaid - Pkt. 5c; oz. $10 \mathrm{c} ; \quad 1 / 4$ lb. $25 \mathrm{c}$; 1b. $90 \mathrm{c}$.

LARGE YELLOW BELGIAN-Makes long yellow roots; about one-third to one-half of the roots grow above the surface and are easily harvested.

Postpaid - Pkt. 5c; oz. $10 \mathrm{c} ; \quad 1 / 4$ tb. $25 \mathrm{c}$; lb. $90 \mathrm{c}$.

\section{Chervil}

Used for flavoring or garnishing, and is more beautiful than Parsley. Sow in early spring in rich soil, and when plants are large enough transplant to a foot apart.

Postpaid - Pkt. 5c; oz. 10c; 1/4 1b. 30c.
Cultivated and grown same as cabbage. Collards are purely a Southern vegetable, largely used in place of cabbage. Collards are considered in the South the old time winter greens. They are improved by the touch of frost. Sow one ounce seed to 200 feet of row.

N. C. BUNCOMBE SHORT STEM-This variety has short stems, large spreading leaves. Has proven very popular wherever grown. A great improvement over the other varieties.

Postpaid-Pkt. 5c; oz. 10c; 1/4 lb. 30c; 1b. $85 \mathrm{c}$.

TRUE GEORGIA or SOUTHERN - A well known and popular sort.

Postpaid-Pkt. 5c; oz. $10 \mathrm{c} ; 1 / 4$ tb. $25 \mathrm{c}$; tb. $70 \mathrm{c}$.

\section{Cress}

WATER CRESS - Is developing into a very profitable vegetable for shipment to large markets. This variety is sown in the spring in beds in damp places or along the edges of ponds, creeks and running streams.

Postpaid-Pkt. 5c; oz. $60 \mathrm{c} ; 1 / 4$ fb. $\$ 2.25$

UPLAND CRESS-Is sown in the spring, in drills about 1 foot apart.

Postpaid-Pkt. 5c; oz. $25 \mathrm{c} ; 1 / 4$ ib. $65 \mathrm{c}$.

\section{Chicory}

Chicory is grown principally for the large thick roots, which are dried and roasted; also the leaves are used as a salad during the early spring.

Postpaid-Pkt. $5 \mathrm{c} ;$ oz. $15 \mathrm{c} ; 1 / 4$ ib. $40 \mathrm{c}$. 


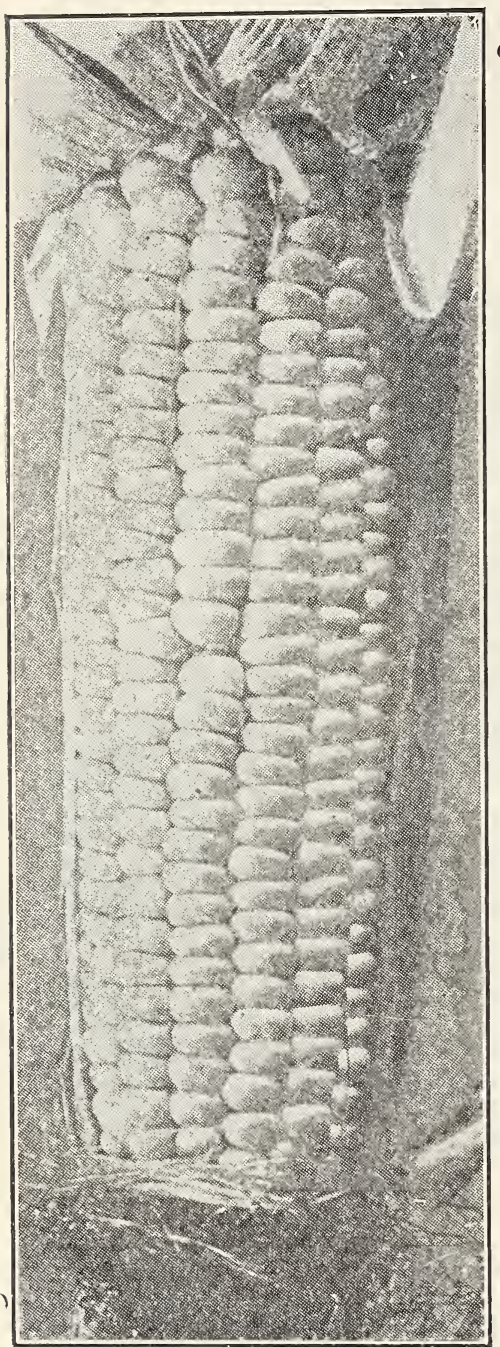

GOLDEN BANTAM SUGAR CORN

\section{(} Garden Corn or Sugar Corn

One pound Seed Corn will plant 100 hills. Ten or twelve pounds for one acre in hills. Plant early varieties last of March or the first of April.

EXTRA EARLY ADAMS-A popular variety in the South Earliest White Corn in cultivation makes small ear and stalk and can be planted close together. If planted in very rich soil and given thorough cultivation produces well filled ears very early.

Postpaid-Pkt. $10 \mathrm{c}$; 1b. $20 \mathrm{c} ; 10$ 1bs. $\$ 1.50$

Express-Lb. $15 \mathrm{c} ; 10$ 1bs. $\$ 1.25 ; 50$ 1b s. $\$ 5.00$.

GOLDEN BANTAM-EXTRA EARLY, SWEET, TENDER AND DELICIOUS-Extremely early, vigorous grower and of delicious flavor. Grain hard and firm but has no flinty glaze, therefore it can be planted earlier than any other true sweet corn. The stalks are dwarf and sturdy in habit, growing to a height of four feet, and can be planted close together in the row; they bear two or three good small ears to the stalk. The grains are yellow. Golden Bantam is truly delicious.

Postpaid-Pkt. $10 \mathrm{c} ; 1 / 2 \cdot 1 \mathrm{~b} .20 \mathrm{c}$; 1b. $30 \mathrm{c}$.

Express-Lb. $25 \mathrm{c} ; 10 \mathrm{1bs} . \$ 2.00 ; 50$ 1bs. $\$ 8.50$

GOLDEN CREAM-A cross of Golden Bantam and Country Gentleman. The result is a yellow Country Gentleman. Ears about size of Country Gentleman and matures about same time, grain is small, deep and zigzagged and of a rich golden color; of excellent quality.

Postpaid-Pkt. 10c; $1 / 2$ ib. 20c; 1b. $30 \mathrm{c}$.

Express-Lb. 25c; 10 1bs. $\$ 2.00 ; 50$ tbs. $\$ 8.50$.

\section{COUNTRY GENTLEMAN-}

Small cob; long, slender, white grain. This variety has a small, white cob, densely covered with irregular rows of v e r y lo $\mathrm{ng}$, slender white grains of excellent quality, ears seven to nine inches long; stands from $61 / 2$ to 7 feet high. Well adapted for canning as well as the home garden and market and by many regarded as the best of the late varieties.

Postpaid-Pkt. 10c :

$1 / 2$ 1b. 20c; 1b. $30 \mathrm{c}$

Express-Lb. 25c

10 tbs. $\$ 2.00 ; 50$ lbs. $\$ 8.50$.

IMPROVED EARLY ADAMS - This is a very hardy sort and can therefore be planted very early. The stout stalks grow 6 to 7 feet in height, bearing one or two large or medium-sized ears, which are well filled with fine white grain that is of excellent quality if pulled at the proper stage.

Postpaid-Pkt. 10c ;

tib. $20 \mathrm{c}: 10$ ibs. $\$ 1.50$.

Express-Lb. $15 \mathrm{c}$; 10 1bs. $\$ 1.25 ; 50$ tbs. $\$ 5.00$.

BLACK MEXICAN-One cannot forget the delicious sweetness and fine qualities in spite of its dark color.

Postpaid-Pkt. $10 \mathrm{c} ; 1 / 2$ 1b. $20 \mathrm{c}$; 1b. $30 \mathrm{c}$.

Express-Lb. 25c; 10 1bs. $\$ 2.00 ; 50$ tbs. $\$ 8.50$.

HOWLING MOB-A fine second early, large eared sort. It produces two pearly white ears to the stalk and is of unsurpassed quality.

Postpaid-Pkt. 10c; $1 / 2$ tb. 20c; 1b. $30 \mathrm{c}$.

Express-Lb. $25 \mathrm{c} ; 10$ tbs. $\$ 2.00 ; 50$ tbs. $\$ 8.50$.

STOWELL'S EVERGREEN - Now recognized everywhere as the standard variety, both for home and market, and is the general favorite. The ears are of a large size, grains deep, exceptionally tender and sugary, and have the advantages of remaining longer in the green state than any other. Our stock has been carefully grown and selected to avoid the tendency to a shorter grain and deterioration in the evergreen character of this best of all sorts.

Postpaid-Pkt. 10c; 1/2 1b. $20 \mathrm{c} ;$ th. $30 \mathrm{c}$

Express-Lb. 25c; 10 1bs. $\$ 2.00 ; 50$ 1bs. $\$ 8.50$.

TRUCKER'S FAVORITE-For a second early corn to follow Adams Early, or for late planting to mature early, this is a good sort. It is a white corn, with good depth of grain, tender and sweet, and makes most desirable size for roasting ears. In addition to being a fine garden corn, it makes an excellent field corn to plant late.

Postpaid-Pkt. 10c; th. 20c; 10 tbs. $\$ 1.50$.

Express-Lb. $15 \mathrm{c} ; 10$ ibs. $\$ 1.25 ; 50$ ibs. $\$ 5.00$.

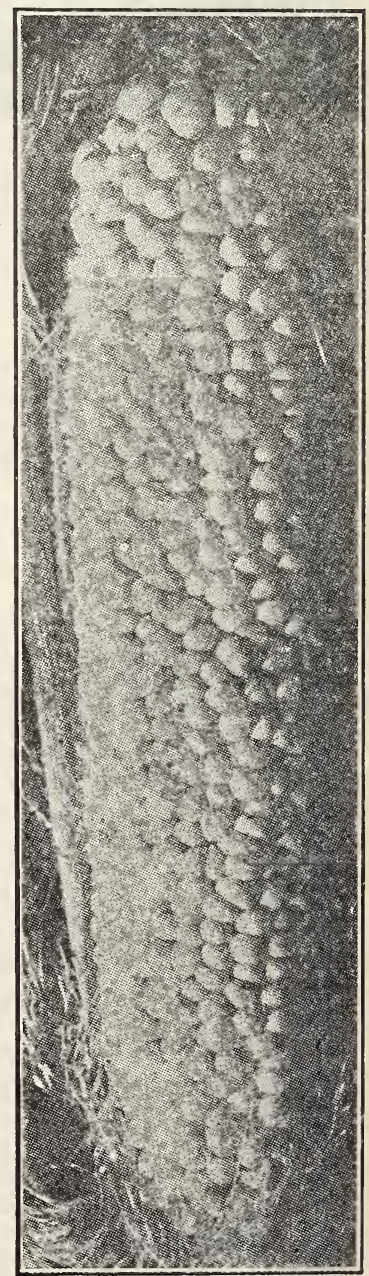

COUNTRY GENTLEMAN 


\section{Cucumbers}

CULTURE OF CUCUMBERS-For early cucumbers sow the first of April in a hot bed upon pieces of sod (grass side down); so that they can be readily transplanted to the open ground in rich soil when danger of frost is over or protect by hand glasses. For early use plant if the weather has become settled and warm, in hills about four feet apart each way. Crop very short, order early.

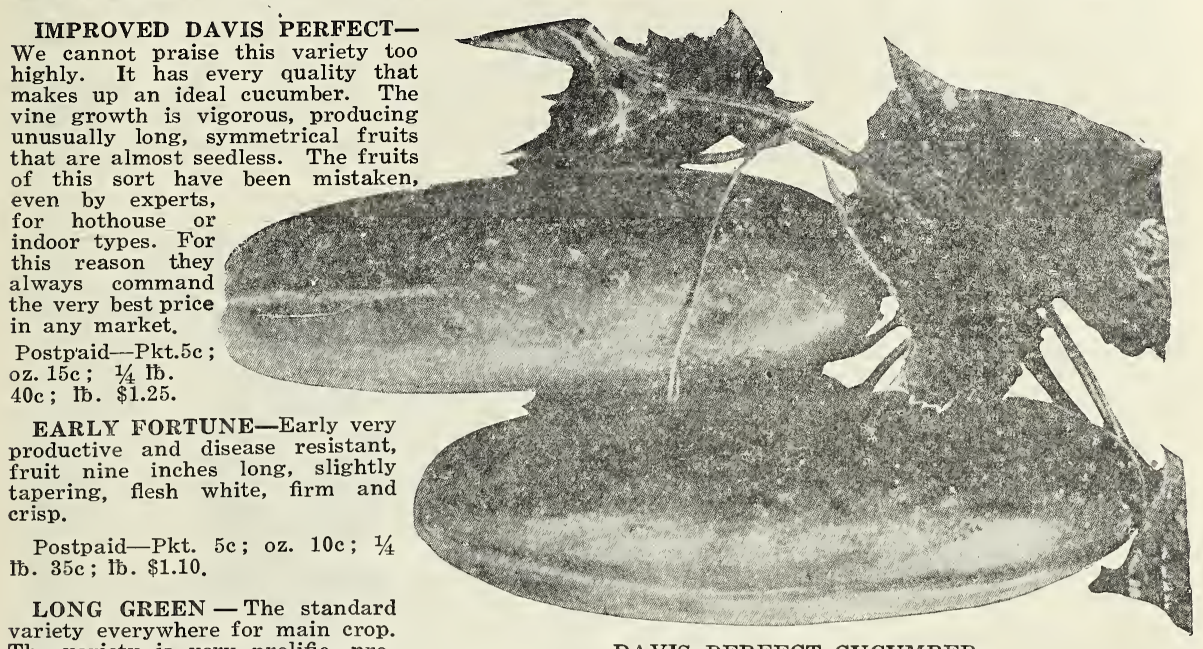
The variety is very prolific, producing unusually long, dark green fruit, very firm, few seeds, and of good eating quality.

Postpaid-Pkt. $5 \mathrm{c} ;$ oz. $15 \mathrm{c} ; 1 / 4 \mathrm{lb} .40 \mathrm{c} ; 1 \mathrm{~b} . \$ 1.40$.

EVERBEARING-This is a very early and an extremely prolific variety. The young fruit is symmetrical, deep in color and crisp. It is an excellent variety to grow for small pickles.

Postpaid-Pkt. 5c ; oz. 15c; $1 / 4$ lb. $40 \mathrm{c} ; 1 \mathrm{~b} . \$ 1.25$.

CHICAGO PICKLE-A small dark green, early, prolific sort, more largely used for pickling purposes than any other sort.

Postpaid-Pkt. 5c; oz. $15 \mathrm{c} ; 1 / 4$ 1b. $40 \mathrm{c} ; 1 \mathrm{~b} . \$ 1.25$.

DAVIS PERFECT CUCUMBER.

EARLY FRAME-An early vigorous growing variety, producing short green fruit of excellent quality; very desirable for pickling.

Postpaid-Pkt. 5c; oz. $15 \mathrm{c} ; 1 / 4$ tb. $40 \mathrm{c} ;$ 1b. $\$ 1.25$.

IMPROVED EARLY WHITE SPINE-A standard and very popular sort with truckers who grow for market and shipping; early and prolific.

Postpaid-Pkt. $5 \mathrm{c}$; oz. $10 \mathrm{c} ; 1 / 4$ 1b. $35 \mathrm{c} ; 1 \mathrm{~b} . \$ 1.10$.

EARLY CLUSTER - An early prolific sort ; green variety, bearing its fruit in clusters. Very desirable for home pickles.

Postpaid-Pkt. 5c ; oz. 15c ; 1/4 1b. $40 \mathrm{c}$; 1b. $\$ 1.25$.

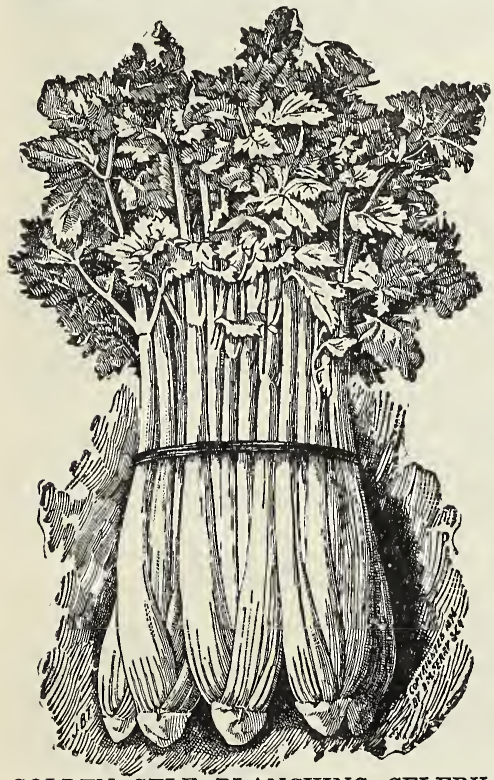

WEST INDIA GHERKIN-A very small, oval shaped pricky variety; grown exclusively for pickling. Very prolific Price-Pkt. 5c; oz. 20c; $1 / 4$ 1b. $50 \mathrm{c} ; 1 \mathrm{~b} . \$ 1.75$.

JAPANESE CLIMBING-A running variety. It bears very quickly and continues to bear throughout the season. The fruit is of extra fine quality, dark green in color and it has very few seeds.

Postpaid-Pkt. 10c ; oz. 15c; $1 / 4$ tb. $40 \mathrm{c} ; 1$ ib. $\$ 1.25$.

\section{Celery}

One ounce sows about 100 feet and produces about 4,000 lants ; $8 \mathrm{oz}$. to one acre Matures from 120 to 160 days.

Culture-Sow seed in February, March or April, in rows and if dry enough, press the soil firmly with a roller or the back of a spade. Keep the seed bed well watered, as celery germinates very slowly. When four inches high, cut off tops to make the plants grow stocky. Transplant from June to September in rows 3 feet apart, 6 inches apart in row.

GOLDEN SELF BLANCHING, FRENCH GROWN-Of a golden yellow color; ribs are brittle, and of a delicious flavor. This is the earliest maturing sort. Stalks are heavy, perfectly solid, about 20 inches high; easily blanched.

Postpaid-Pkt. $15 \mathrm{c} ;$ oz. $75 \mathrm{c} ; 1 / 4$ tb. $\$ 3.00 ; 1 \mathrm{~b} . \$ 10.00$

IMPROVED WHITE PLUME-A great favorite, crisp and tender. The plants grow rapidly and blanch easily during the summer months.

Postpaid-Pkt $10 \mathrm{c} ;$ oz. $50 \mathrm{c} ; 1 / 4$ tb. $\$ 1.50 ;$ tb. $\$ 5.00$

GIANT PASCAL-Splendid variety for fall and winter use. It blanches to a yellowish white color, and is solid, crisp, and of fine flavor.

Postpaid-Pkt. $10 \mathrm{c} ;$ oz. $50 \mathrm{c} ; 1 / 4$ lb. $\$ 1.50 ; 1 \mathrm{~b} . \$ 5.00$.

CELERY PLANTS-See page 30.

\section{Celeriac or Turnip-Rooted Celery.}

The roots have the flavor of celery; are excellent for flavoring soups and salads.

GOLDEN SELF BLANCHING CELERY. Postpaid-Pkt. 5c; oz. 30c ; 1/4 ib. 90c; ib. \$3.25. 


\section{Egg Plant}

One ounce for 1,000 plants, requires about 4 ounces to plant an acre. Matures in about 120 days from sowing.

Egg plant is one of the most delicious vegetables. They grow and fruit exceptionally well in the South, and are very high in food value. Sow seed early in hot beds and transplant into well fertilized situations, when all danger of frost is past.

NEW YORK IMPROVED SPINELESS-This is an entirely spineless strain of the large purplefruited, which is the well-known standard. The plants are equally as productive, fruits as large and well colored, but stems and calyx entirely free from spines.

Postpaid-Pkt. 5c; oz. 40c; 1/4 1b. $\$ 1.50$.

FLORIDA BIG BUSH-Very vigorous and productive, bearing very profusely its large purple fruits of fine shape and quality. Resist drought and wet weather to a great degree, on account of its strong upright growth.

Postpaid-Pkt. 5c; oz. 35c; $1 / 4$ tb. $\$ 1.20$.

BLACK BEAUTY-Ten days or two weeks earlier than the preceding, with fruits just as large, of uniform shape and rich, lustrous black color. Fruits develop very quickly and planters will be pleased with them.

Postpaid-Pkt. 5c; oz. $45 \mathrm{c} ; 1 / 4$ lb. $\$ 1.50$.

EGG PLANTS-Large, stocky, transplanted olants. Ready March 1st till July. See page 31 .

\section{Kale or Borecole}

One ounce to 150 feet of drill, or broadcast two pounds to acre.

A salad of the cabbage family; extremely easy and very profitable to grow; broadcast same as turnips; very hardy.

DWARF CURLED SCOTCH-A very early dwarf, hardy sort.

Postpaid-Pkt. 5c; oz. $15 \mathrm{c} ; 1 / 4$ tb. $40 \mathrm{c} ;$ tb. $\$ 1.35$.

TALL CURLED SCOTCH-A tal!, growing sort; very hardy.

Postpaid—Pkt. 5c; oz. 15c; 1/4 lb. 40c; 1b. $\$ 1.35$.

LONG STANDING SIBERIAN-The hardiest of the lot; very popular.

Postpaid-Pkt. 5c; oz. 10c; $1 / 4$ tb. $35 \mathrm{c} ; 1 \mathrm{~b} . \$ 1.25$.

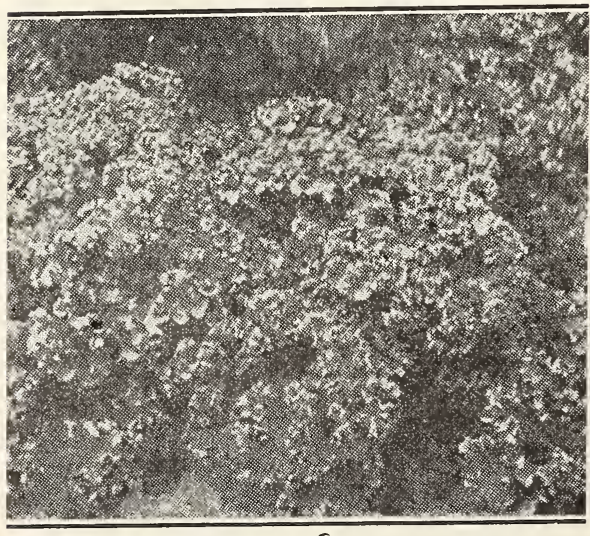

DWARF CURLED SCOTCH KALE

\section{Endive}

One ounce will sow 100 feet of row; 3 pounds will plant 1 acre of land in rows 3 feet apart.

Culture-A delightful salad. Sow in April, May, and June, in rows 18 inches apart, thin to 1 foot in the row; tie outer leaves up over the center and bleach.

MOSS GREEN CURLED-A very hardy, dark leaved sort; crisp and tender; should be bleached. Postpaid-Pkt. 5c; oz. $15 \mathrm{c} ; 1 / 4 \mathrm{lb} .45 \mathrm{c}$; $1 \mathrm{tb} . \$ 1.20$.

WHITE CURLED-Almost clear white sort; very fine.

Postpaid-Pkt. 5c; oz. $15 \mathrm{c}$; $1 / 4$ lb. $45 \mathrm{c}$; 1b. $\$ 1.25$.

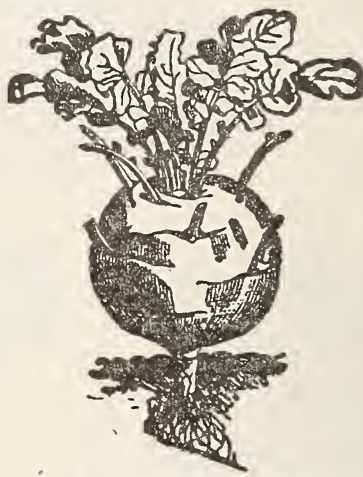

WHITE VIENNA KOHLRABI

\section{Kohlirabi}

One ounce to 100 yards of row.

A vegetable intermediate between the cabbage and turnip, which combines the flavor of both. It forms a turnip-shaped bulb above the ground, which is prepared for the table like turnips. If used when young and tender, makes a delicate and desirable vegetable. Also known as "Turniprooted Cabbage." Sow in rows 18 to 20 inches apart, thinning out to 8 inches.

EARLY WHITE VIENNA-A light green type; the most popular.

Postpaid-Pkt. 5c ; oz. $20 \mathrm{c}$; $1 / 4$ tb. $65 \mathrm{c}$; 1b. $\$ 2.35$.

\section{Leek}

The Leek' belongs to the Onion family. Sow the seed and care for the young plants as for onions, but they need more room in order to develop. When the young plant is about the size of a goose quill, transplant to a prepared bed in rows about 3 or $31 / 2$ feet apart and 4 or 5 inches in the row. Set the roots deep and draw the earth to them when cu'tivating, so that they may be well blanched by the time they are fit for use.

LONDON FLAG-This is a variety generally cultivated in this country. It is hardy and of good quality.

Postpaid-Pkt. 5c; oz. $20 \mathrm{c} ; 1 / 4$ tb. $75 \mathrm{c} ;$ ib. $\$ 2.50$.

\section{Horse Radish}

Horse Radish rarely produces seed, but is grown from pieces of the roots. Mark off the rows $21 \%$ feet apart, in rich, moist, well-prepared ground, and set the pieces of roots 18 inches apart in the rows vertically, the small end down and the top 1 to 2 inches below the surface. Cultivate thoroughly until the tops cover the ground, when their shade will keep down the weeds.

Postpaid-Per doz. $20 \mathrm{c}$; per $100, \$ 1.25$. 


\section{Select Lettuce}

Culture - Sow in hot-beds in February and March, harden off and set out 8 to 12 inches apart in 18 inch rows. For succession, sow every three weeks. Sowing may be made in open ground early in the spring and the plants thinned out. Lettuce is easy to grow, but requires rich, moist soil, clean and thorough cultivation, and plenty of water to give it that quick growth on which depends its tenderness and flavor. After plants are set out a side-dressing of nitrate of soda will stimulate their growth.

One ounce will sow about 150 feet of drill or produce 3,000 plants.

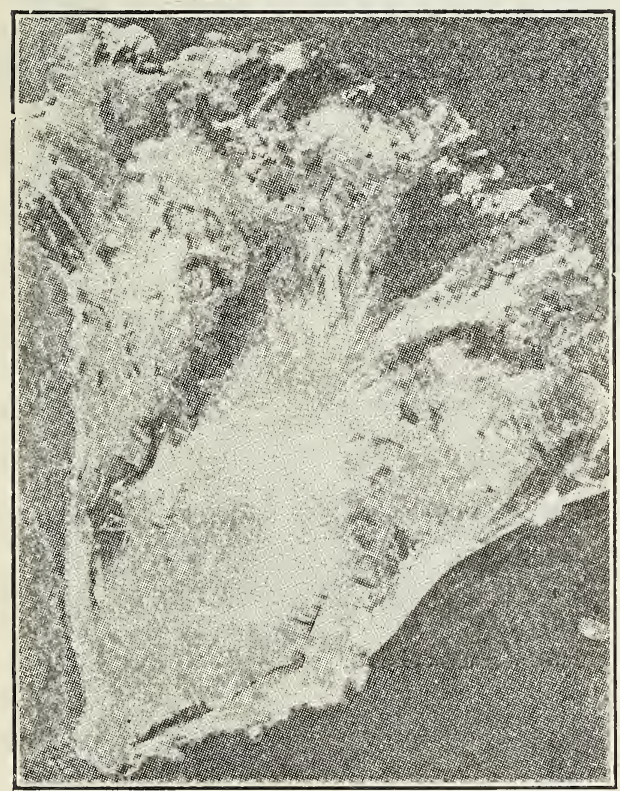

Grand Rapids Lettuce.
Lettuce, not only being "wayahead" in earliness, but the tightly folded heads are generally larger in size. The outer leaves a light green, with the inner head finely bleached to a rich buttery yellow. "Wayahead" stands a longer time before running to seed than any other early head variety.

Postpaid-Pkt. 5c; oz. $15 \mathrm{c} ; 1 / 4$ 1b. $35 \mathrm{c}$; 1b. $\$ 1.25$.

BIG BOSTON-(Improved Selected.) Very distinct variety, grown largely in the South as a winter lettuce, Very popular for outside culture as well as cold frame forcing. Head large and compact; leaves broad, almost smooth, but wavy at the edge; color light green, slightly tinged reddish-brown; heart greenish-white tinged yellow, and quite tender when we!l grown. It gives he best of satisfaction under all possible condiions.

Postpaid-Pkt. 5c ; oz. $15 \mathrm{c} ; 1 / 4$ 1b. 40c; 1b. $\$ 1.35$.

ICEBERG-A good variety for either the market gardener or for family use. Somewhat similar o Hanson, but smaller and of slightly darker olor. It matters not whether grown to head in arly spring or in the hottest days of summer, he leaves are always tender and crisp.

Postpaid-Pkt. 5c; oz. $15 \mathrm{c} ; 1 / 4$ tb. $50 \mathrm{c} ;$ ib. $\$ 1.75$.

WONDERFUL (NEW YORK)-This splendid mammoth heading, long-keeping variety has been srown to weigh 6 lbs. to the head; frequently veighs 2 or 3 lbs. Heart is solid, of light green o'or, very sweet, tender and crisp. Long standng, perfect heads may be cut from the same bed for many weeks.

Postpaid-Pkt. 5c; oz. 20c; 1/4 1b. 70c; 1b. $\$ 2.50$. MAY KING-Of quick growth and produces arge, handsome heads with few outside leaves. Color light green, outer leaves folding closely, כroducing round, solid heads 6 to 7 inches in diimeter. Splendid for market gardeners or private use.

Postpaid-Pkt. 5c; oz. 15c; 1/ ib. 35c; 1b.\$1.25. PARIS WHITE COS or CELERY LETTUCEThe Cos Lettuces are quite distinct, and they are oopular on account of their tender, crisp leaves and delicious flavor. The leaves are long and narrow, and need to be tied up, when they soon form solid conical heads and bleach snow white. Postpaid-Pkt. $5 \mathrm{c}$; oz. $15 \mathrm{c} ; 1 / 4 \mathrm{tb} .40 \mathrm{c}$; 1b. $\$ 1.35$. CALIFORNIA CREAM BUTTER or ROYAL SUMMER CABBAGE-A very reliable heading variety; leaves glossy, deep green, very solid head. Postpaid-Pkt. 5c; oz. $15 \mathrm{c} ; 1 / 4$ tb. $40 \mathrm{c} ; 1 \mathrm{~b} . \$ 1.35$. LETTUCE PLANTS-See page 31.

\section{Curled Varieties}

GRAND RAPIDS-A good lettuce to sow outside early in the spring for family use. Makes large, compect bunches of light, attractively curled and fringed leaves. It grows very rapidly and keeps in good marketable condition for a long time quality and handsome appearance make it a popular variety.

Postpaid-Pkt. $5 \mathrm{c}$; oz. $15 \mathrm{c}$; $1 / 4$ lb. $35 \mathrm{c}$; 1b. $\$ 1.25$.

BLACK-SEEDED

SON-One of th for forcing under glass or for open ground culture. It forms large, thin, loose leaves of light green color, very tender, crisp and of fine quality.

Postpaid-Pkt. $5 \mathrm{c}$; oz. $15 \mathrm{c}$ $1 / 4$ 1b. $35 \mathrm{c}$; 1b. $\$ 1.25$.

Cabbage or Heading Varieties

WAYAHEAD LETTUCE-

The earliest butter-head,

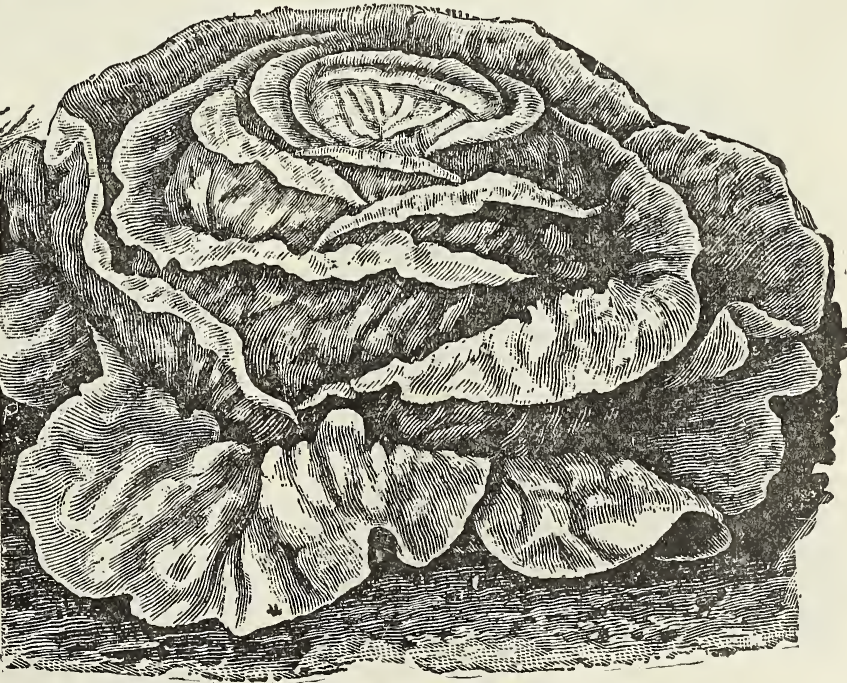

Big Boston Lettuce. 


\section{Muskmelon or Cantaloupe}

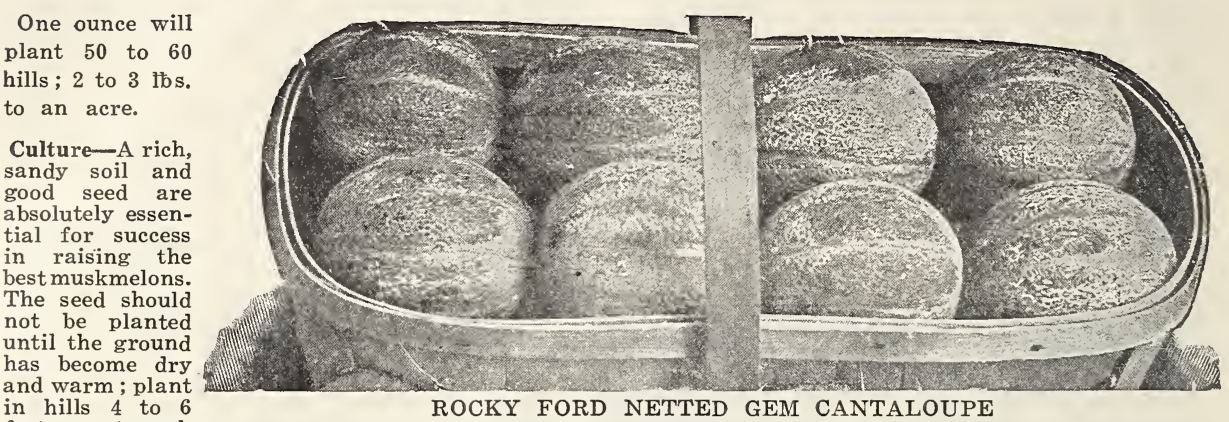

in hills 4 to 6

feet apart each

way; old well-rotted manure should be thoroughly mixed with the soil in each hill and in liberal quantity. Put from 6 to 10 seeds to the hill, and when danger of insects destroying the young plants is past thin out 3 or 4 plants. Give frequent but shallow cultivation until vines cover the ground.

ROCKY FORD NETTED GEM (SELECTED STRAIN)-The most popular melon in cultivation. It is without doubt the most uniformly good sort. Very popular as a shipper, fruits stand handling with little or no damage. Early and very prolific; flesh is light green with salmon flesh near the seed. We offer seed of the very finest strain, grown for us by specialists in this line, and subjected to the greatest care in selecting and curing.

Postpaid-Pkt. $5 \mathrm{c}$; oz. $10 \mathrm{c}$; $1 / 4$ lb. $35 \mathrm{c}$; 1b. $\$ 1.10$.

BANANA-The fruit is very long, cucumbershaped, 18 to 24 inches; flesh yellow, thick and of most delicious odor and flavor.

Postpaid-Pkt. $5 \mathrm{c}$; oz. $20 \mathrm{c} ; 1 / 4$ 1b. $50 \mathrm{c} ; 1 \mathrm{~b} . \$ 1.60$.

EXTRA EARLY HACKENSACK-An early sort, maturing in about 60 days, running from medium to large; deeply ribbed, tough rind sort. A very valuable shipping variety. Flesh light green to pink at the center.

Postpaid-Pkt. 5c; oz. $15 \mathrm{c} ; 1 / 4$ lb. $35 \mathrm{c} ; 1 \mathrm{~b} . \$ 1.25$.

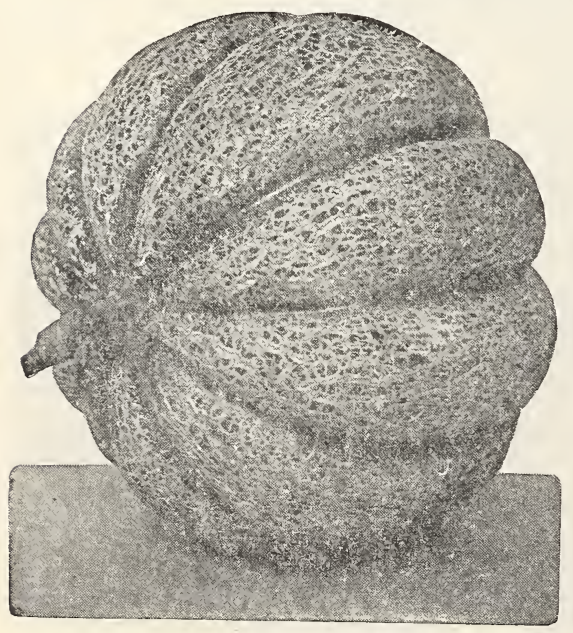

LARGE HACKENSACK or TURK'S CAPHardy and productive. Melons are of extra large size, nearly round, heavily ribbed and netted. Flesh is green, thick and very sweet.

Postpaid-Pkt. $5 \mathrm{c}$; oz. $15 \mathrm{c}$; $1 / 4$ 1b. $40 \mathrm{c}$; 1b. $\$ 1.25$.

TIP TOP-This very productive melon varies in shape from round to slightly oblong rather large in size and somewhat late in maturing. Skin pale green, distinctly ribbed and fairly well covered with shallow netting. The flesh is rich, deep salmon in color, and it is sweet and juicy.

Postpaid-Pkt. $5 \mathrm{c}$; oz. $15 \mathrm{c}$; $1 / 4 \mathrm{lb} .35 \mathrm{c}$; 1b. $\$ 1.25$.

FORDHOOK-The rind, though thin, is unusually firm and well netted; the thick salmon flesh is solid and sweet to the rind. One of the finest for market, also equally as good for the home garden. The introducer pronounced it equal to the Emerald Gem in delicious flavor.

Postpaid-Pkt. $5 \mathrm{c}$; oz. $15 \mathrm{c} ; 1 / 4$ 1b. $40 \mathrm{c}$; 1b. $\$ 1.50$.

EMERALD GEM-The fruit is of good size, very smooth and of deep emerald green color. The flesh is of a rich salmon color, and ripens thoroughly to the extreme thin rind, and is very sweet and rich of flavor; very hardy and prolific, and grows to perfection in the South. The melon follows the extra early sorts in ripening and lasts longer than most any variety. This melon is very popular for home gardens.

Postpaid-Pkt. $5 \mathrm{c}$; oz. $15 \mathrm{c} ; 1 / 4$ 1b. $40 \mathrm{c}$; 1b. $\$ 1.50$.

DELICIOUS GOLD LINED ROCKY FORD-It is medium in size, of round, oval form. Meat of a beautiful golden color, deliciously sweet, very prolific and hardy.

Postpaid-Pkt. 5c; oz. $15 \mathrm{c} ; 1 / 4$ 1b. $40 \mathrm{c} ;$ 1b. $\$ 1.35$.

HONEY DEW-This late variety has become extremely popular on account of its large size and excellent quality. The fruit is ovoid in form, about 10 inches long and 8 inches in diameter; surface smooth and hard, without ribbing or netting: creamy white in color turning to lemon tint when fully ripe; flesh light emerald green; very thick, ripening to the rind; very tender with an extreme sweetness found in no other melon. An excellent variety for storing.

Postpaid-Pkt. $5 \mathrm{c}$; oz. $15 \mathrm{c} ; 1 / 4 \mathrm{lb} .45 \mathrm{c} ; 1 \mathrm{~b} . \$ 1.60$.

\section{Colorado Pink Meat}

Beautifuliy netted, but the flesh is pink or salmon. Its shipping and eating qualities are excellent.

Postpaid-Pkt. $5 \mathrm{c}$; oz. $15 \mathrm{c} ; 1 / 4$ 1b. $45 \mathrm{c} ; 1 \mathrm{~b} . \$ 1.50$. 


\section{Selected Southern Grown Watermelon Seed}

One ounce will plant 30 hills; 3 tbs. for 1 acre.

The watermelon seed we offer is Southern Grown and far superior (contrary to the general rule in seed), to those grown in the North. Watermelon seed produced North or West and grown in the South produces melons with a hard core and are not used by the large melon growers in the South, although frequently can be obtained at a much lower price. Culture-Prepare the soil by thoroughly working in well rotted manure, pulverized sheep manure or poultry droppings ; rich soil gives the plants a good start before insects attack them. Make hills 8

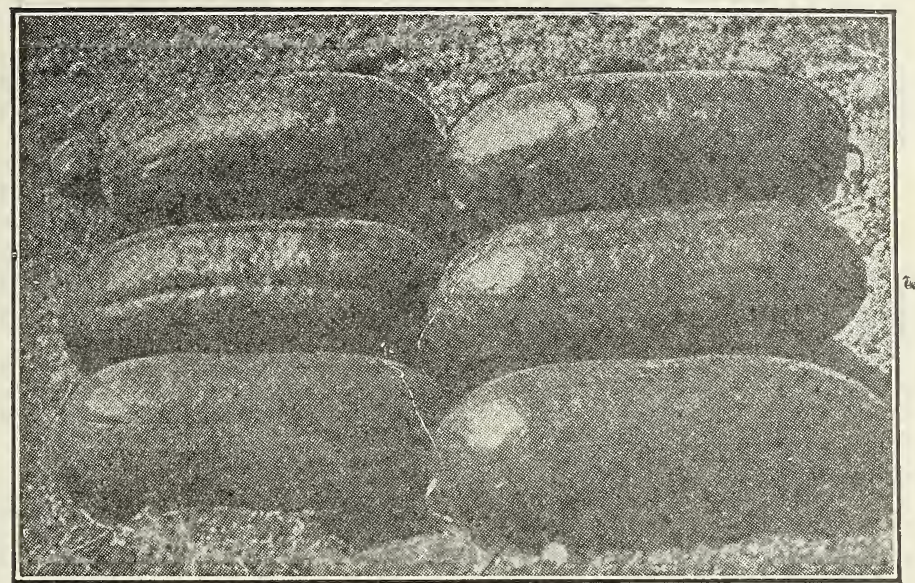

Genuine Tom Watson Watermelon.

feet apart each way, plant 6 to 8 seeds to a hill, covering 1 inch deep; when well up thin out, leaving three strong plants to a hill.

NOTE-Do not neglect to spray your melon vines with Bordo Mixture, it will help to increase the yield and prevent diseases that often destroy the melon crop in the South. See page 51 for description and price of Bordo Mixture.

To prevent and destroy Bugs, dust the vines with Slugshot. See Insecticides, page 51 for price on Slugshot.

GEORGIA RATTLESNAKE-One of the largest, oldest and most popular sorts, especially in the South. Fruits very long, of light green color, distinctly striped and blotched with a darker shade. Flesh bright scarlet, very sweet and tender.

Postpaid--Pkt. 5c; oz. 10c; $1 / 4$ 1b. $30 \mathrm{c} ; 1 \mathrm{~b} .90 \mathrm{c}$

HARRIS' EARLIEST WATERMELON-Sweetest, largest early watermelon. Melon is oval to ob. long; beautifully striped with green and grey; bright red flesh which is sweet, tender and delicious. It is a melon for everybody to grow who wants to be first in the market with fine large melons weighing 20 to 30 pounds.

Postpaid-Pkt. $5 \mathrm{c}$; oz. $10 \mathrm{c} ; 1 / 4$ th. $30 \mathrm{c}$; th. $\$ 1.00$.

HALBERT'S HONEY-One of the newer varieties of splendid quality and especially desirable for home use or nearby markets. They are much like Kleckley's Sweet, or Monte Cristo, but longer in shape; have a dark green thin rind; exceedingly bright scarlet meat, so crisp and tender that a well ripe melon splits ahead of the knife when cutting. Melons are long, blunt at both ends, and the vines are very productive.

Postpaid-Pkt. $5 \mathrm{c}$; oz. $10 \mathrm{c} ; 1 / 4$ tb. $30 \mathrm{c}$; tb. $\$ 1.00$.

ICE CREAM or PEERLESS-A popular melon for home and market. Oblong, with dark green, finely grained skin. Flesh sweet, deep pink, solid to the center.

Postpaid-Pkt. $5 \mathrm{c}$; oz. $10 \mathrm{c}$; $1 / 4$ tb. $30 \mathrm{c}$; th. $90 \mathrm{c}$.

COLORADO CITRON OT PRESSING MELONAlso called apple pie.

Postpaid-Pkt. $5 \mathrm{c}$; oz. $15 \mathrm{c} ; 1 / 4$ tb. $50 \mathrm{c}$.

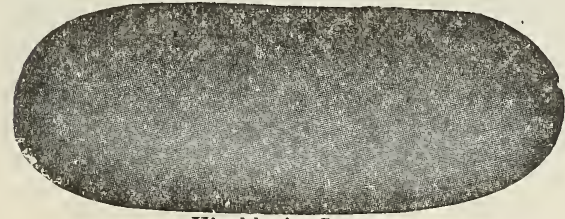

KLECKLEY'S SWEET-This is the famous "Sweetest of all." Without doubt one of the finest melons grown. Long thin rind. Not a shipper, but one of the finest for home use.

Postpaid-Pkt. $5 \mathrm{c}$; oz. $10 \mathrm{c} ; 1 / 4$ 1b. 30c; tb. $\$ 1.00$.

\section{Tom Watson}

The melons are large, long and dark green like the Kleckley Sweet, but larger, and has a tougher rind, consequently is an excellent shipper for long distances. The deep flesh or meat is a beautiful rich red, solid and lusciously sweet and ripens close up to the vine. The vines are vigorous and very productive, although a shipping melon, its extra fine quality commends it to the private gardener. The heart is large with no sign of core. The seeds are brown tipped with white. Our seeds are Southern grown, which are the best.

Postpaid-Pkt. $5 \mathrm{c}$; oz. $10 \mathrm{c} ; 1 / 4$ tb. $30 \mathrm{c}$; tb. $90 \mathrm{c}$.

FLORIDA FAVORITE-A large, smooth, beautifully shaped melon of dark green color, irregularly striped with light green, very early and exceedingly prolific. The rind is of medium thickness, very hard and tough, making an excellent sort for shipping. The flesh is of bright red color, sweet and juicy.

Postpaid-Pkt. $5 \mathrm{c}$; oz. $10 \mathrm{c}$; 1/4 ib. $30 \mathrm{c}$; 1b. $90 \mathrm{c}$.

SWEET HEART-A medium early variety growing to a very large size. Vines vigorous and productive, melons oval, light green in color, striped and veined with a darker shade. Flesh bright red and tender.

Postpaid-Pkt. 5c; oz. $10 \mathrm{c}$; $1 / 4$ Ib. $30 \mathrm{c}$; 1b. $90 \mathrm{c}$.

\section{OKRA OR GUMBO.}

Cultivated for its green seed-pods, which are used in soups or stewed and served like asparagus. Highly esteemed in the South for making gumbo soup. Can be cured like dried apples and then used for soup at any time.

Culture-When the soil has become warm, sow thickly in rows 3 feet apart, and when large enough, thin out to a foot apart in the rows.

One ounce will sow 30 foot row.

WHITE VELVET OKRA-This is a distinct and beautiful Okra. The pods are much longer than any other variety, perfectly smooth, and covered with a fibre resembling velvet.

Price-Pkt. 5c; oz. $10 \mathrm{c} ; 1 / 4$ ib. $20 \mathrm{c}$; to. $65 \mathrm{c}$.

PERKINS MAMMOTH LONG POD-An early, and very prolific, long green-podded variety; height 4 to $4^{1 /}$ feet, and ouality of the best.

Price-Pkt. $5 \mathrm{c} ;$ oz. $10 \mathrm{c} ; 1 / 4$ tb. $25 \mathrm{c}$; 1b. $75 \mathrm{c}$. 


\section{Mustard}

One ounce sows 30 feet; 4 or 5 pounds per acre. This is grown to quite a large extent in the Southern States. It is used the same as spinach, or boiled with meats as greens. The white or yellow-seeded variety is cultivated chiefly for medicinal purposes or pickling.

Culture-Sow during February, March or April, or in the fall during September or October, either broadcast or in rows 6 inches apart. Cut when about 3 inches high.

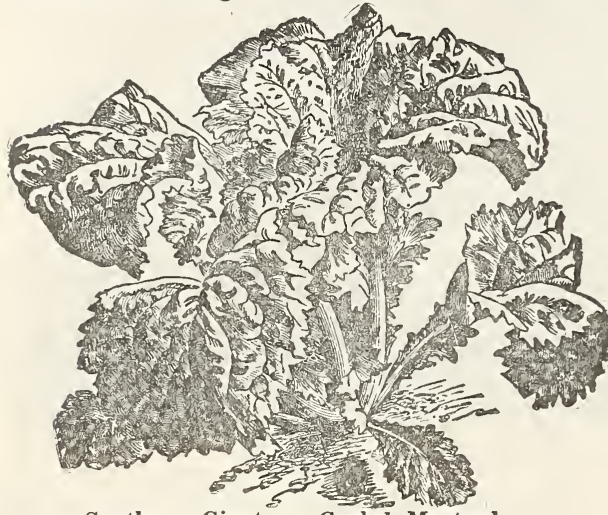

Southern Giant or Curled Mustard.

SOUTHERN GIANT CURLED-Forms a great mass of light green leaves beautifully frilled and finely curled. Succulent, pungent, and of sweet flavor. The most popular with Southern growers. Postpaid-Pkt. 5c; oz. 10c; $1 / 4$ 1b. 20c; 1b. 60c.

OSTRICH PLUME - This variety stands the summer heat finely. Is considered the most beautiful of all mustards. Leaves are long, ruffled and curled as graceful as the ostrich plume.

Postpaid-Pkt. $5 \mathrm{c}$; oz. $10 \mathrm{c}$; $1 / 4$ 1b. $20 \mathrm{c}$; 1b. $60 \mathrm{c}$.

CHINESE BROAD LEAF-Ready in six weeks from sowing. Leaves are twice the size of the white, and the stems more succulent. Pleasantly sweet and pungent.

Postpaid-Pkt. $5 \mathrm{c}$; oz. $10 \mathrm{c} ; 1 / 4$ 1b. $25 \mathrm{c}$; 1b. $75 \mathrm{c}$.

WHITE-Leaves comparatively smooth, dark green. Mild and tender when young.

Postpaid-Pkt. $5 \mathrm{c}$; oz. $10 \mathrm{c} ; 1 / 4$ 1b. $20 \mathrm{c}$; 1b. $60 \mathrm{c}$.

BLACK-Stronger and more pungent than white. Postpaid-Pkt. 5c; oz. $10 \mathrm{c}$; 1/4 1b. 20c; 1b. $60 \mathrm{c}$.

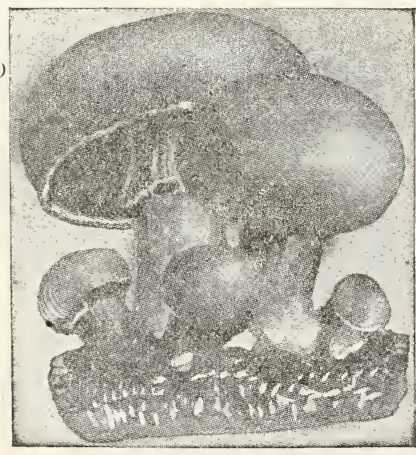

\section{Mushroom Spawn}

Mushrooms are much enjoyed as table luxury. They may be grown in a variety of situations-a dark room, cellar, stable, in sheds, under green house benches-where the temperature can be maintained at 50 to 65 degrees. Ten pounds of spawn are required for ten feet square.
ENGLISH MILLTRACK SPAWN-Stock of recent importation. It comes in bricks weighing 20 ounces. Each brick is sufficient for 8 square feet of bed.

Price-Per brick, 25c (by mail, 35c). By express -5 lbs. $\$ 1.00 ; 10$ lbs. $\$ 1.50$. Purchaser pays the transportation charges.

\section{Superior Onion Seed}

One ounce will sow 100 feet of drill; 5 pounds is required to make plants enough to set an acre. Culture-Large Onions from Seed-To grow large onions from seed the first year, sow in January, February or early in March in hot beds, or in the open ground later, and when the weather opens and the plants are the size of a goose quill, transplant 4 or 5 inches apart in 12 to 18 inch rows, Transplanting always increases the yield, sometimes doubles it.

The onion is best grown in a rich, sandy loam. Continued cultivation upon the same plot of ground, contrary to the general rule, rather improves the crop than otherwise.

PRIZE TAKEP, or SPANISH KING-It is one of the largest, handsomest and most profitable varieties grown. By sowing early and transplanting it can be grown to an extraordinary size. The Prize Taker Onion is globe-shaped; of a clean, bright yellow or straw color. Has a small neck and ripens up hard. Keeps well until about midwinter. Flesh thick, white, mild and agreeable in flavor. It is easily grown, medium early maturing.

Postpaid-Pkt. $5 \mathrm{c}$; oz. $20 \mathrm{c} ; 1 / 4$ 1b. $65 \mathrm{c} ; 1 \mathrm{~b} . \$ 2.35$.

LARGE RED WEATHERSFIELD - The most widely cultivated red variety, the standard winter Onion; a sure and heavy yielder; the best keeper grows to an immense size, solid, oval-shaped, flattened on top; skin purplish red, smooth and glossy; flesh white. This variety does best on rich, moderately dry soil, but on low muck land it is more apt to form large necks than the Danvers. There is no better sort for poor and dry soils.

Postpaid-Pkt. 5c; oz. $20 \mathrm{c} ; 1 / 4$ 1b. $60 \mathrm{c} ; 1 \mathrm{~b} . \$ 2.25$.

LARGE YELLOW GLOBE DANVERS - This improved variety is largest in size and uniformly globe shaped, has small necks and ripens evenly. Fine keeper; matures early.

Postpaid-Pkt. 5c; oz. 20 c; $1 / 4$ lb. 60 c; 1b. $\$ 2.25$.

SILVER SKIN, or WHITE PORTUGAL-(See illustration) - The bulbs are flat. It is of a mild, pleasant flavor and is a splendid variety, both for home use and the market gardener. It is extensively used for growing sets, for which it is well adapted on account of the shape of the bulb and its excellent keeping qualities. It is also used largely for pickling.

Postpaid-Pkt. $5 \mathrm{c}$; oz. $20 \mathrm{c} ; 1 / 4$ tb. $70 \mathrm{c} ; 1 \mathrm{tb} . \$ 2.60$.

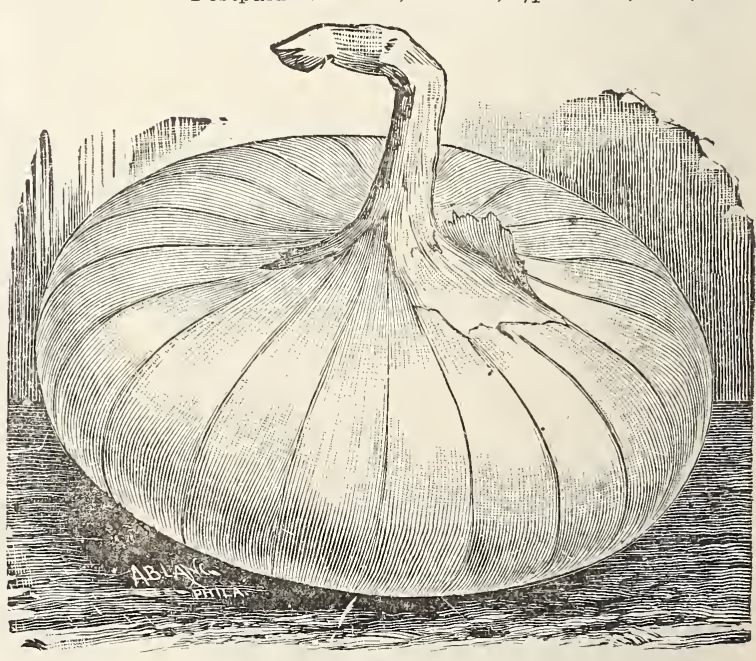

SILVER SKIN OR WHITE PORTUGAL ONION 


\section{Onion Sets}

One quart will plant 50 feet of row; 4 to 6 bushels will plant an acre.

SILVER SKIN-Best white Onions for growing from sets. Mild flavor and good keepers.

Postpaid-Quart 25c; peck $\$ 1.25$; bushel $\$ 4.15$.

Express-Quart 20c; peck $\$ 1.10$; bushel $\$ 3.75$.

YELLOW DANVERS-One of the best keepers and the most popular variety to plant in the spring from sets.

Postpaid-Quart 25c ; peck $\$ 1.25$; bushel $\$ 4.15$.

Express-Quart 20c; peck $\$ 1.10$; bushel $\$ 3.75$.

LARGE RED WEATHERSFIELD - A favorite maket variety and large cropper.

Postpaid-Quart 25c; peck $\$ 1.15$; bushel $\$ 4.00$.

Express-Quart 20c; peck $\$ 1.00$; bushel $\$ 3.60$.

WHITE MULTIPLIER-Or Nest Onions; very productive, of finest flavor; better keepers than the Yellow Multiplier, and does not make as large onions as they do.

Postpaid-Quart 30c ; peck $\$ 1.55$; bushel $\$ 5.50$.

Express-Quart 25c; peck $\$ 1.35$; bushel $\$ 5.00$.

YELLOW POTATO, MULTIPLIER-These make large reddish-brown Onions of a mild flavor; excellent qualities.

Postpaid-Quart 30c ; peck $\$ 1.55$; bushel $\$ 5.50$.

Express-Quart 25c; peck $\$ 1.35$; bushel $\$ 5.00$.

The prices of onion sets fluctuate. We are one of the largest handlers of high-grade sets in the South. Write for our quantity prices on fancy stocks.

\section{Parsnips}

One ounce sows about 150 feet; 5 to 6 pounds to the acre.

They require a deeply prepared loam for their fullest development. The seed are very slow to germinate, and should be sown early in the spring in rows 18 inches apart for hand cultivation, or 30 inches apart for horse cultivation. Thin out to six inches to row. Cultivate often.

SUGAR or HOLLOW CROWN-The very best sort in existence. A large yielder of the finest quality.

Postpaid-Pkt. $5 \mathrm{c}$; oz. $10 \mathrm{c} ; 1 / 4$ lb. $30 \mathrm{c}$; 1b. $90 \mathrm{c}$.

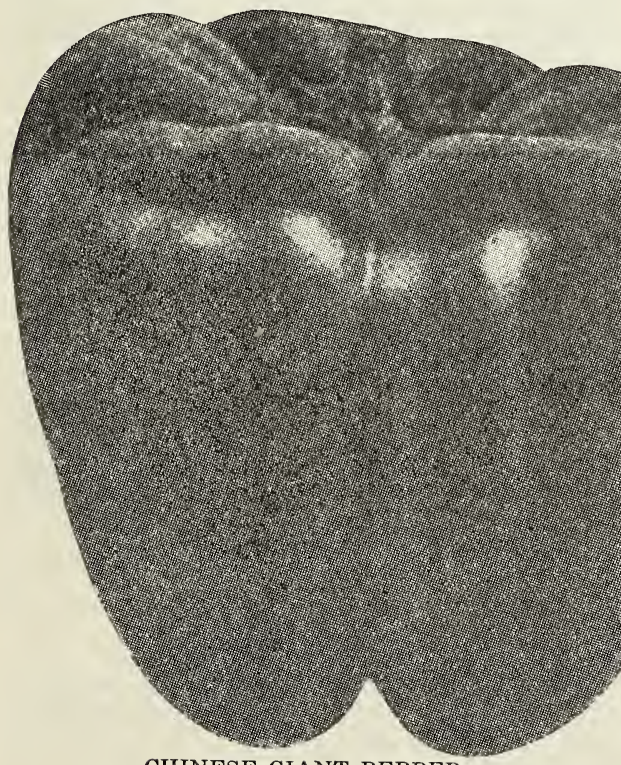

CHINESE GIANT PEPPER

CHINESE GIANT-Absolutely the largest sort that grows; enormous, sweet flavored pods; thick, crisp fiesh of delightful mild flavor. Plants bushy, coming to bear early and growing a large crop of its four-lobed pods. Very few seed. An ideal salad and stuffiing sort.

Postpaid-Pkt. 5c; oz. 50c; $1 / 4$ ib. $\$ 1.75$.

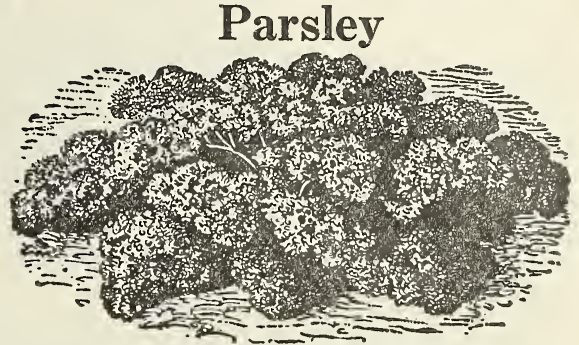

One ounce sows 150 feet of row.

Culture-Sow in February, March or early in April, half an inch deep, in rows a foot apart, pressing the soil after sowing. Parsley is slow to germinate, sometimes two or three weeks in coming up. Germination may be hastened by soaking the seeds several hours before sowing, or by covering the rows with boards to retain the moisture.

Fall sowings should be made in August or September in hot-beds or cold frames. Top dress with well rotted manure or a good ammoniated fertilizer.

CHAMPION MOSS CURLED - The best and most improved strain. It is beautifully curled and crimped, and is best for garnishing and flavoring. If cut when about 3 inches high, it starts a new growth that will be better curled and a brighter color. It makes an ornamental plant for edging walks.

Postpaid-Pkt. $5 \mathrm{c}$; oz. $10 \mathrm{c} ; 1 / 4$ tb. $30 \mathrm{c}$; th. $\$ 1.00$.

PLAIN or SINGLE-Very hardy, and stronger in flavor than the curled.

Postpaid-Pkt. 5c; oz. 10c; $1 / 4$ lb. $30 \mathrm{c}$; 1b. $90 \mathrm{c}$.

\section{Peppers}

One ounce will produce 1000 to 1500 plants.

Peppers should be sown early in boxes or hotbeds and transplanted into a loamy well fertilized situation in rows about 2 feet apart and 18 inches to 2 feet in the row. Cultivate often and thoroughly, continuing until frost, and you will be rewarded with a continuous crop as long as cultivation is kept up. The seed we ofler is the very best strain, carefully tested.

PIMENT 0-Sweetest pepper grown, a very thick fleshed, heart-shaped, smooth mild crimson variety, much used for salads; very prolific.

Postpaid-Pkt. $5 \mathrm{c}$; oz 50c; 1/4 1b. $\$ 1.75$.

RUBY KING-This is a fine variety, growing from $41 \%$ to 6 inches long, and 3 to 4 inches thick. The flesh is very thick, mild and pleasant to the taste. It is a fine sort for stuffing or for pepper hash, and also makes an excellent dish for salad.

Postpaid-Pkt 5c; oz. 50c; 1/4 tb. $\$ 1.65$. MAMMOTH BELL or BULL NOSE - This is the most popular of all sweet varieties; very mild in flavor; flesh very thick. Fine variety for pickling. Postpaid-Pkt. 5c; oz. 45c; $1 / 4$ tb. $\$ 1.50$.

SWEET MOUNTAIN-Similar to

Bell; very popular for stuffed pickles.

Sweet and mild flavored. It is very

large, smooth and handsome.

Postpaid-Pkt. 5c; oz. 50c; 1/4 tb. $\$ 1.60$. LONG RED CAYENNE-This is a fine, long, lender variety, very hot, bright red, and of exceedingly delicate flavor as a seasoner. It is a good keeper. When fully ripe can be gathered, dried and strung for winter use.

Postpaid-Pkt. $5 \mathrm{c}$; oz. $40 \mathrm{c} ; 1 / 4$ lb. $\$ 1.50$.

GOLDEN DAWN-Color bright golden yellow; very brilliant and handsome.

Postpaid-Pkt. 5c; oz. 65c; 1/4 to. $\$ 2.25$.

CELESTIAL - Conical fruits, creamy tinted,

turning to scarlet when ripe.

Postpaid-Pkt. 5c : oz. 40c; $1 / 4$ lb. $\$ .150$

PEPPER PLANTS-See page 31 . 


\section{Garden or English Peas}

Two pounds will plant 100 feet of row; 90 to 120 ibs. to acre.

Culture-Plant the smooth varieties as early as the ground can be worked, in rows 3 to 4 feet apart, 2 inches deep, giving the later sorts more room between the rows. The wrinkled peas more not as hardy as the smooth sorts, and should are not as hardy as the smooth sorts, and should flavored. Peas mature earliest in a light, rich soil; for general crop a moderately heavy soil is best.

\section{Extra Early Bunch Varieties}

EXTRA EARLY FIRST AND BEST-We can strongly recommend this pea for early use. It is hardiest, the most prolific and profitable of all early sorts. The well-filled pods containing usually 6 to 8 peas, retain their beautiful green color long after being picked. Grows 2 to $2 \frac{1}{2}$ feet high.

Postpaid-Pkt. 10c; $1 / 2$ tb. $20 \mathrm{c}$; 1b. $35 \mathrm{c}$.

Express-Lb. $25 \mathrm{c} ; 10 \mathrm{lbs} . \$ 2.25 ; 50 \mathrm{lbs} . \$ 9.00$.

ALASKA LARGE-PODDED - EARLIEST OF ALL-Matures in pods in about 35 days, which are filled with medium sized, bright green peas of good flavor. The vines grow from $2 \frac{1}{2}$ to 3 feet high. Uniform maturity and other distinct valuable qualities have made it popular with the gardeners and canners.

Postpaid-Pkt. 10c; 1/2 lb. 20c; 1b. 35c.

Express-Lb. 25c; 10 lbs. $\$ 2.25 ; 50$ lbs. $\$ 9.00$.

AMEER-An extra large-podded pea of excellent quality. Vines grow about 3 feet in height, producing large, finely-shaped pods. The peas ripen uniformly and are round, slightly dented, of bright green color. A prolific bearer, making it a valu-

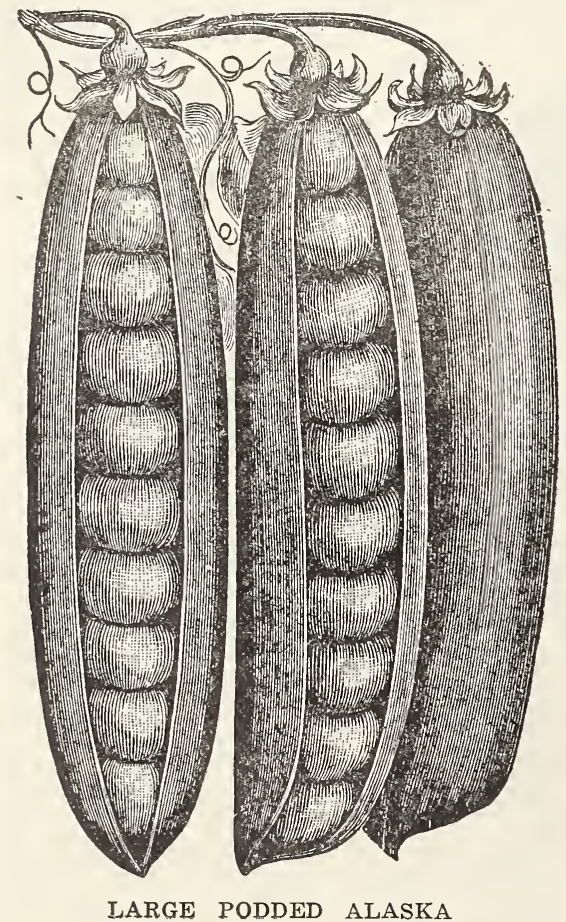

able market gardener's sort. If you desire a fine large-podded pea that will mature early, one that fills the hamper quickly, plant Our Ameer, or Large-Podded Alaska.

Postpaid-Pkt. $10 \mathrm{c}$; $1 / 2$ 1b. $20 \mathrm{c}$; 1b. $35 \mathrm{c}$

Express-Lb. 25c; 10 Ibs. $\$ 2.25 ; 50$ lbs. $\$ 9.00$.

FRENCH CANNER-Choicest Pea for canners very prolific, bearing in pairs, long curved, well filled pods, kernels small; excellent flavor. Grows about 3 feet tail.

Postpaid-Pkt. 10c; 1/2 1b. 20c; 1b. 35c.

Express-Lb. $25 \mathrm{c} ; 10 \mathrm{lbs} . \$ 2.25 ; 50$ lbs. $\$ 9.00$.

DWARF TELEPHONE - An excellent second crop variety, growing only $21 / 2$ feet tall. The vines and foliage is dark green and exceptionally vigor ous. The pods are dark green and about $4 \frac{1}{2}$ ins. long; they contain 8 or 9 peas of best quality.

Postpaid-Pkt. 10c; 1/ tb. 20c; 1b. 35c.

Express-Lb. $25 \mathrm{c} ; 10 \mathrm{lbs}$. $\$ 2.25 ; 50 \mathrm{lbs} . \$ 9.00$.

NEW EARLY GRADUS or PROSPERITYExtremely early; large deep green pods; exquisite flavor. This remarkable pea is not only large and of the best quality, but is within 2 or 3 days as early as the small, round, extra early sorts. Gradus is a wrinkled pea, growing about 30 inches high; the pods are of a bright green color, measuring 4 inches or more in length, as large as Telephone, well filled with luscious peas, 8 to 10 or more in a pod. The peas are of the highest table quality and retain in a remarkable manner their color and attractive appearance after cooking.

Postpaid-Pkt. $10 \mathrm{c} ; 1 / 2$ 1b. $20 \mathrm{c}$; 1b. $35 \mathrm{c}$.

Express-Lb. $25 \mathrm{c} ; 10 \mathrm{lbs} . \$ 2.25$; 50 lbs. $\$ 9.00$

BLUE BANTAM-This superb pea is unequaled for its extreme earliness, unusual productiveness, and rare quality. The vines are distinctly dwarfed and bear an enormous crop of large, deep, bluish green pods 4 inches long and well filled with 8 or 9 deep bluish green peas of excellent flavor.

Postpaid-Pkt. 10c; 1/ 1b. 20c; tb. 35c

Express-Lb. $25 \mathrm{c} ; 10 \mathrm{lbs}$. $\$ 2.25 ; 50$ lbs. $\$ 9.00$.

THOMAS LAXTON-Experts consider this the best early variety of wrinkled pea. The strong vine has heavy stems, with large, light green leaves, and grows 3 feet tall. It bears large pods about 4 inches long, well filled with enormous peas of a sweet flavor and delicate tenderness.

Postpaid-Pkt. $10 \mathrm{c}$; $1 / 2$ lb. $20 \mathrm{c}$; 1b. $35 \mathrm{c}$.

Express-Lb. $25 \mathrm{c} ; 10 \mathrm{lbs}$ s. $\$ 2.25 ; 50$ lbs. $\$ 9.00$

NOTT'S EXCELSIOR-Early dwarf wrinkled; tender and of fine flavor. Vines average about 12 inches high; pods medium sized, about $23 / 4$ inches long. The peas, in sweetness and quality, are unsurpassed. Seed medium sized, wrinkled, green and somewhat flattened. A most desirable sort for the market gardener and unsurpassed for the home garden.

Postpaid-Pkt. $10 \mathrm{c}$; 1/2 1b. 20c; 1b. 35c.

Express-Lb. $25 \mathrm{c} ; 10 \mathrm{lbs}$. $\$ 2.25 ; 50 \mathrm{lbs} . \$ 9.00$

\section{Salad Peas}

MAMMOTH MELTING SUGAR-It is the very best edible pea obtainable. The large broad pods are of delicious sweet flavor, being very brittle and entirely stringless.

Postpaid-Pkt. 10c; $1 / 2$ lb. $20 \mathrm{c}$; lb. $35 \mathrm{c}$.

Express-Lb. $25 \mathrm{c} ; 10$ 1bs. $\$ 2.25$.

DWARF GREY SUGAR - An edible pod pea which grows only 2 feet tall. It is a very prolific bearer of fine quality peas.

Postpaid-Pkt. 10c;1/ 1b. 20c: 1b. 35c.

Express-Lb. 25c; 10 1bs. $\$ 2.25$. 


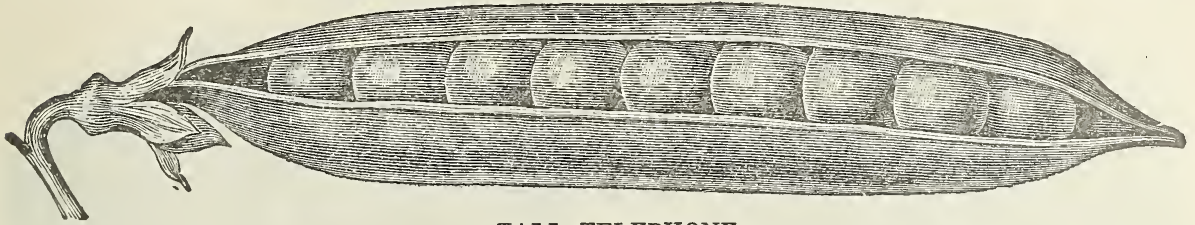

TALL TELEPHONE

\section{Pole Peas}

TALL TELEPHONE-Large pods; prolific does well everywhere. Immediately productive; finest quality; excellent flavor; vines very strong, growing about 4 feet high, and should be given support; produces an abundance of pointed pods of largest size, often $4 \frac{1}{2}$ to 5 inches long, attractive bright green, filled with very large peas which are tender, sweet and of excellent flavor.

Postpaid-Pkt 10c; 1/ 1b. 20c; ib. 35c.

Express-Lb. 25c ; 10 tbs. $\$ 2.25$; 50 lbs. $\$ 9.00$.

CHAMPION OF ENGLAND-Prolific and hardy; small pod but well filled. An old standard wrinkled variety, growing 4 to 5 feet high. The pods are large and the peas tender and sweet. The bearing period is prolonged, it being a hardy grower. Very productive and universally admitted to be one of the richest and best flavored peas; seed light green and much shriveled.

Postpaid-Pkt. 10c; $1 / 2$ tb. 20c; 1b. 35c.

Express-Lb. 25c; 10 Ibs. $\$ 2.25$; 50 ibs. $\$ 9.00$.

LARGE WHITE MARROWFAT-Good market variety; tall, splendid flavor. Cultivated extensively for the summer crop. About 5 feet high, of strong growth. The pods are large, cylindrical, rough, light colored and well filled; seed large, smooth, round and light yellow.

Postpaid-Pkt. 10c; 1/2 1b. 20c; 1b. $35 \mathrm{c}$.

Express-Lb. 25c; 10 tbs. $\$ 2.25 ; 50$ lbs. $\$ 9.00$.

\section{Genuine Maine Grown Seed Irish Potatoes}

E A R L I E R MORE PRODUCTIVE.

The famous Maine grown seed potatoes richly deserve the high favor they have won in America. Under $\mathrm{n}$ or m a 1 growing conditions, seed from this source yield an abundant crop of tubers, true to type and of superior quality. Potatoes planted in many sections soon "run out," become watery and yield poorly; the Maine seed always reproduce a good yield of delicious mealy tubers. Our stock is grown and selected for seed by a reliable expert in Miaine; each bag will have the government inspector's tag, showing that they have been inspected and areearly variety. Maine grown stock of this variety free from scab.

Six to 10 bushels will plant an acre.
Plant first crop of Early Rose the last week in TRIUMPH or RED BLISS-An extremely hardy

is especially productive and of fine quality. February. Irish Cobblers and Green Mountainred skinned variety, nearly round, eye deeply incan be planted as late as August with excellentdented, white flesh. Produces large fine potatoes results.

THE IRISH COBBLER-Gardeners both large Write for prices. and small are enthusiastic in their praise of this GREEN MOUNTAIN-A reliable medium late excellent variety. This handsome white potatovariety which is universally popular. It thrives is extremely early, maturing fully 10 days earlierin all soils and in all sections, producing a heavy than Farly Rose. The tubers are smooth, roundvield of large, smooth, white skinned tubers. and plump, with creamy white skin evenly and There is no variety superior in quality to Green slightly netted, an indication of distinctive quali-Mountain; it has a delightful dry mea!y flavor ty. The eyes are strong, well developed, and butwhen cooked. A good variety to store for winter slightly indented.

Write for prices.

Write for prices.

EARLY ROSE-An old time favorite, extra early The prices of potatoes fluctuate. Write us in maturing, productive, and of excellent quality.stating quantities and varieties you are interested Next to the Irish Cobbler, we sell more Earlyin and we will quote you attractive prices. Be Rose, since it is a most satisfactory all-roundsure to plant Maine grown seed. 


\section{Pure Bred Pumpkin Seed}

One ounce will plant 25 hills; 2 to 3 ths. to acre.

Pumpkins are rapidly growing in favor throughout the South. The larger and coarser sorts make excellent stock food, while the majority of the sorts make excellent pies and are also used in a number of other ways.

Pumpkins may be planted most any time during spring and early autumn in hills 10 to 12 feet apart among corn rows, or in the open. They produce the best crops in deep loam, but are not particular about the soil, if the same has been well fertilized. Potash in some form is essential to their fullest development.

The pumpkin seed listed in this catalogue should not be compared with ordinary field stocks with no identity gathered up here and there. Our stocks have been as carefully grown and selected as the most sensitive garden or flower seed, and we have priced them at the lowest possible figure.

KEN'TUCKY FIELD-A very popular Southern sort; large and flattened. A wonderful keeper; a good stock variety; also a valuable eating and pie sort. Skin mottled light green and yellow changing to a creamy yellow when they mature. Flesh yellow, tender and of excellent quality.

Postpaid-Plkt. $5 \mathrm{c}$; oz. $10 \mathrm{c} ; 1 / 4$ 1b. $25 \mathrm{c}$; tb. $75 \mathrm{c}$.

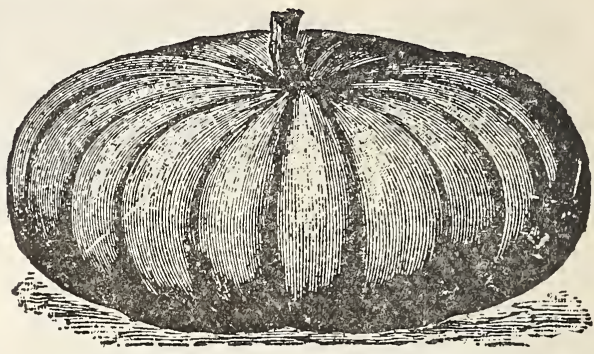

SUGAR OR PIE PUMPKIN

SUGAR or PIE-It is deeply ribbed. The outer color of the skin is dark green-almost black. It is not a large pumpkin, but one of the sweetest and best for pies. It is fine grained deliciously sweet, and a very good keeper; the flesh is rich, deep orange yellow in color.

Postpaid-Pkt. 5c; oz. $10 \mathrm{c} ; 1 / 4$ lb. $30 \mathrm{c} ; 1 \mathrm{~b} . \$ 1.10$

TENNESSEE SWEET POTATO - Of medium size and nearly bell shaped, with neck slightly crooked. The creamy white sk:n is sometimes slightly green striped. The flesh is of creamy white color, deep, fine grained, and of unsurpassed quality for stock feeding or making pies. Postpaid-Pkt. 5c oz. $15 \mathrm{c} ; 1 / 4$ lb. $45 \mathrm{c}$; lb. $\$ 1.50$

LARGE CHEESE PUMPKINThis is one of the best late varieties. The skin is of a bright orange and the flesh yellow and sweet. It is also a good keeper, and very fine for wintering stock.

Postpaid-Pkt. 5c; oz. 10c ;

$1 / 4$ ib. $25 \mathrm{c}$; 1b. $75 \mathrm{c}$.

CANDY ROASTER-This variety, as well as we know, is being grown exclusively in Western North Carolina. It is a hybrid between the Pumpkin and Winter Squash. The meat has a sweeter flavor than either. When first stewed, then put in a pan, putting spice and sugar on it and baking or roasting, it has the flavor of "candied" sweet potatoes. It is also often cut up in small pieces and put in the stove and baked or roasted. After sprinkling sugar over it the rind has a brownish-gray color, sometimes mixed with the orange yellow. Seeds are large, with a polish and hard surface.

Seed limited. Price-Pkt. 10c ; oz. $25 \mathrm{c} ; 1 / 4$ tb. $85 \mathrm{c}$

KING OF MAMMOTH-This is the largest pumpkin in the world, and has been known to reach 250 pounds in weight. It is of grayish yellow color, and is only grown for stock feeding or as a curosity.

Postpaid-Pkt. 10c; oz. 20c ; $1 / 4$ tb. $50 \mathrm{c}$; ib. $\$ 1.75$.

GREEN STRIPED CUSHAWThis is one of the finest pumpkins in existence, a long, crooked neck, terminating in a round or oblong end, enclosing a very small seed cavity; flesh surrounding seed cavity very thick. The neck is absolutely solid, rivaling the finest sweet potatoes for baking, or as a pie sort it has no equal. A splendid keeper. Postpaid-Pkt. $5 \mathrm{c}$; oz. $15 \mathrm{c}$; $1 / 4$ tb. $45 \mathrm{c}$; tb. $\$ 1.50$.

GOLDEN YELLOW or YELLOW CUSHAW-Similar in every way to the Green Striped Cushaw, except in color, being a dark golden yellow. Very sweet.

Postpaid-Pkt. 5c; oz. $15 \mathrm{c}$; 


\section{Radish}

One ounce sows 100 feet of drill; 9 to 10 tbs. to an acre.

Culture-For an early supply sow in a hot-bed in February, care being taken to give abundant vetilation to prevent running to leaves. For open-air culture and succession, sow from middle of March until September at intervals of ten days. Radish do best in a rich loamy soil and must be cultivated often and thoroughly, as it is very important to mature the crop quickly, to retain their crisp, tender quality.

RAPID RED - The quickest growing round red radish. Some of our customers report the remarkable fact that they grew some of these radish large enough to eat in 12 to 15 days, while the average time of maturing is from 18 to 20 days from planting. The radishes are perfectly round; three-quarters of an inch in diameter, with thin bright red skin, firm white flesh, crisp and mildly pungent; 'leaves short and small.

Postpaid--Pkt. $5 \mathrm{c}$; oz. $15 \mathrm{c} ; 1 / 4$ 1b. $45 \mathrm{c}$; 1b. $\$ 1.25$.

SCARLIET TURNIP, WHITE TIPPEDA beautiful variety, deep scarlet, white tipped. Recommended to gardeners as an excellent early also a splendid variety to sow late in the summer for fall use. It is very attractive looking and always a good seller on the market.

Price-Pkt. 5c; oz. $10 \mathrm{c} ; 1 / 4$ tb. $30 \mathrm{c}$; ib. $90 \mathrm{c}$.

EARLY SCARLET GLOBE-This variety is one of the finest for forcing and market gardening purposes. Shape roundish oval; large, brilliant red; flesh white, solid, crisp and very mild; tops small.

Postpaid-Pkt. 5c; oz. 10c; $1 / 4$ 1b. $30 \mathrm{c}$; 1b. $90 \mathrm{c}$.

GLASS, or CINCINNATI MARKET-It is very early and is splend:d for forcing or open ground. Tops small; they grow straight and smooth from 4 to 7 ins. long. Skin scarlet colored, very thin, and flesh crisp, brittle and of delightful flavor. Postpaid-Pkt. 5c; oz. $10 \mathrm{c} ; 1 / 4$ 1b. $30 \mathrm{c} ; 1 \mathrm{~b} .90 \mathrm{c}$.

FRENCH BREAKFAST-A medium size radish, half long stump rooted, small top, quick growth and tender. Excellent variety for the table.

Postpaid-Pkt. $5 \mathrm{c}$; oz. $10 \mathrm{c} ; 1 / 4$ tb. $30 \mathrm{c}$; 1b. $90 \mathrm{c}$.

LONG WHITE ICICLE, or LADY FINGERAlso called White Vienna. A beautiful transparent white variety, about 3 inches long, and $1 / 2$ inch in diameter, with small tops; very crisp and brittle, and remains in good condition a long time; does not get pithy. Suitable for forcing. The best white radish.

Postpaid--Pkt. $5 \mathrm{c}$; oz. $10 \mathrm{c} ; 1 / 4$ 1b. $30 \mathrm{c}$; 1b. $90 \mathrm{c}$.

CRIMSON GIANT - This new variety, introduced some time ago, differs radically from all other existing sorts. Its roots attain more than double the size of those of other globe varieties, without becoming pithy or hollow. The new Giant develops 6 or 7 inches around, weighing over an ounce, their pure white flesh remaining firm, crisp and of mildest flavor. The roots are almost perfect globes, of a deep crimson color.

Postpaid-Pkt. $5 \mathrm{c}$; oz. $10 \mathrm{c} ; 1 / 4$ 1b. $30 \mathrm{c}$; 1b. $90 \mathrm{c}$.

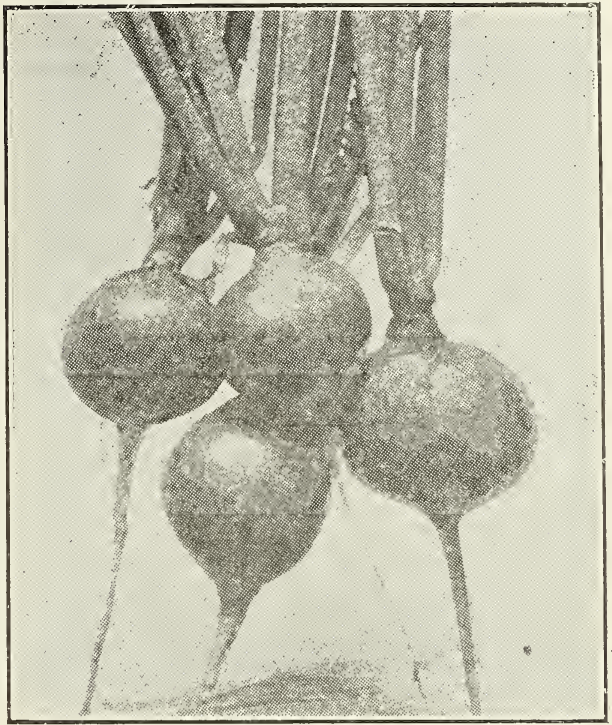

RAPID RED RADISH

BEST WINTER VARIETY-CRISP AND PUNGENT.

CHINESE ROSE WINTER-(Scarlet Chinese). One of the very best for fall and winter use, and popular with market gardeners. Bright rose color: flesh white of superior quality.

Postpaid-Pkt. $5 \mathrm{c}$; oz. $10 \mathrm{c} ; 1 / 4$ 1b. $30 \mathrm{c}$; 1b. $95 \mathrm{c}$.

\section{RHUBARB ROOTS}

Do best in a moist or shady place, set out early in the spring or fall in deep well worked soil, 4 feet apart each way. Mix freely with manure or coarse litter.

Postpaid-Large roots, 30c each; $\$ 3.25$ per doz.

Express, not prepaid-Each $25 \mathrm{c} ; \$ 2.50$ per doz.

\section{SALSIFY, or OYSTER PLANT}

One ounce sows 50 foot row; 3 to $4 \mathrm{fbs}$. to acre.

Culture-This plant succeeds best in a light well enriched soil, which, previous to sowing, has been stirred to a depth of 12 to 14 inches. Make drills about 3 inches deep and from 18 to 24 inches apart; sow seed in drill about 1 to 2 inches. When plants are 3 inches high, thin to 3 inches apart.

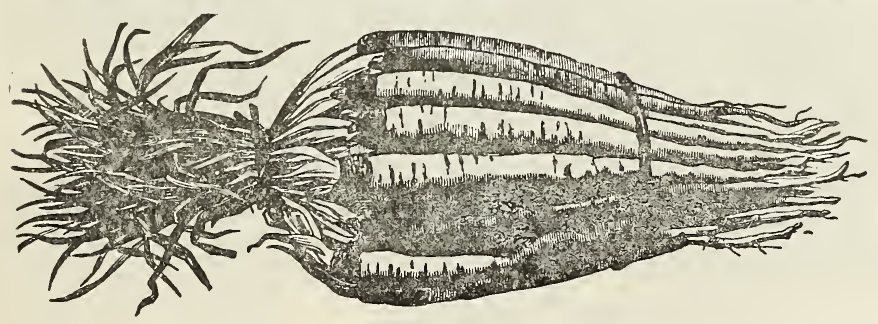

Mammoth Salsify
MAMMOTH SALSIFY(See Cut) This is a great improvement in the salisfy plant. The roots are much larger, less stringy and more delicate flavored. The most popular market sort.

Postpaid--Pkt. 5c; oz. 15c ; $1 / 4$ tb. $50 \mathrm{c} ;$ ib. $\$ 1.85$. 


\section{Spinach Seed}

One ounce sows about 100 feet of drill; 10 to 15 pounds per acre in drills.

This is a very important crop in our market gardens, and is one of the most easily managed of all vegetables, requiring but little culture, and may be had fit for use the entire season. The main crop is sown in September but for summer use it may be sown at intervals of 2 or 3 weeks from April to August. The fall sowings should be covered, when in exposed places, only with straw or litter during the winter to prevent frosting. Spinach is most tender and sweet when grown in rich soil; it finds a ready and profitable market.

B L O O M S D A L E SAVOY LEAVED(NORFOLK SAVOY.) This very early and hardy variety is the popular favorite of the market gardener and the canner. The plant grows upright, the crumpled leaves are medium in size, and of beautiful dark green color, crisp, and tender. In extremely hot weather it has a tendency to go to seed, but for fall planting it is a very superior variety.

Postpaid-Pkt. 5c; oz. 10c; 1/4 tb. 20c; tb. 50c.

LONG STANDING-Many varieties suffer in hot weather, running to seed. Long Standing Spinach is peculiarly adapted for withstanding hot weather. The plant is small, with lustrous green leaves which are short, broad, very thick, and of such substance that little bulk is lost in cooking. It has unequaled flavor and tenderness.

Postpaid-Pkt. $5 \mathrm{c}$; oz. $10 \mathrm{c} ; 1 / 4 \mathrm{tb} .20 \mathrm{c}$; 1b. $50 \mathrm{c}$.

NEW ZEALAND-The stems and leaves are soft, thick, and fleshy, and of a crystalline appearance. The plants are heat resisting, and make vigorous growth in summer even during hottest weather. Only the leaves are used for greens, but they make delicious greens all summer. New Zealand Spinach is killed at first frost.

Postpaid-Pkt. 5c; oz. 15c; $1 / 4$ 1b. $30 \mathrm{c} ; 1 \mathrm{tb} . \$ 1.0 \mathrm{n}$.

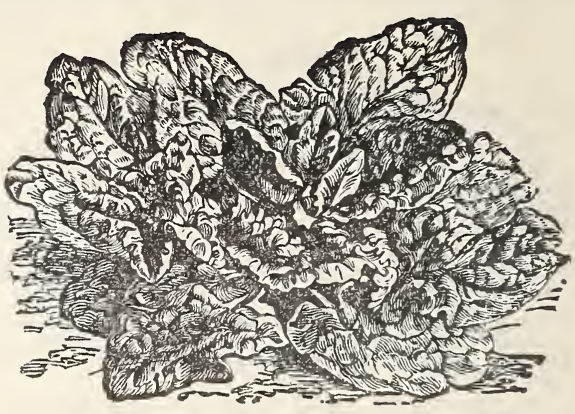

SPINACH.

\section{Squash}

One ounce plants 25 hills; 3 to 4 pounds to an acre.

Culture-Plant in hills after danger of frost is past in a warm, well-pulverized, rich soil. Hills for bush varieties 4 feet apart, running sorts 8 feet apart.

\section{Early Summer Varieties}

EXTRA EARLY WHITE BUSH OR PATTY PAN-Of a light green color. Early, very prolific, a nice size; very popular for shipping, for nearby markets and home use.

Postpaid-Pkt. 5c; oz. $15 \mathrm{c} ; 1 / 4$ 1b. $40 \mathrm{c} ; 1 \mathrm{tb} . \$ 1.50$

GIANT SUMMER CROOKNECK-It's the best summer squash, and is as large as the ordinary Summer Crookneck, far more warty and several days earlier. This combination of earliness, large size and wartiness, which adds so much to its attractiveness, makes it altogether the most desirable squash for the market and private garden. Color, a rich golden yellow.

Postpaid-Pkt. $5 \mathrm{c}$; oz. $15 \mathrm{c} ; 1 / 4$ 1b. $45 \mathrm{c} ; 1 \mathrm{~b} . \$ 1.60$.

\section{Winter Varieties}

CHICAGO WARTED HUBBARD-This seems to be, by all odds, the best strain of Hubbard Squash we have ever known. Some of its good points are large size, dark green, almost black color, all looking alike, and withal distinguished by a dense covering of knots ("warts") ; thick fleshed, of first-class quality; a good keeper. Postpaid-Pkt.5c; oz.15c ; $1 / 4$ 1b. $50 \mathrm{c}$; 1b. $\$ 1.75$.

F O R D H O O K-This squash can be either used as a summer or winter variety. Color bright yellow, meat thick and good quality.

Postpaid - Pkt. 5c ; oz. $15 \mathrm{c} ; 1 / 4$ tb. $45 \mathrm{c}$; 1b. $\$ 1.50$.

DELICIOUS-Very similar to the Hubbard, but of much superior flavor and a more reliable cropper.

Postpaid-Pkt.5c ; oz.15c $1 / 4$ 1b. $50 \mathrm{c}$; 1b. $\$ 1.75$.

MAMMOTH CHILI Favorite variety for exhibition purposes. Attains an immense size. Excellent for stock Can also be used for the table, as the flesh is fine-grained and of good flavor. Postpaid-Pkt.5c; oz.15c $1 / 4$ tb. $45 \mathrm{c}$; 1b. $\$ 1.50$. 


\section{Choice Tomato Seed}

One ounce of seed will produce about 2,000 plants.

Culture-For early use, sow in February or March, in a hot-bed or in boxes, which should be placed near a window. When the seedling are about 2 inches high, transplant in 2 or 3 -inch pots, or in rows 4 to 5 inches apart, keeping the temperature at about 60 degrees. Subsequent transplanting will make the plants stockly and strong. Do not set them in the open ground until all Do not set them in the open ground until all warm, sunny location, 3 feet apart each way, and water freely until they are well established.

No vegetable occupies the prominence and infinite care, selection, etc., in the seedman's time and business as the tomato. The strains and selections of the country in which the seed crops are grown have so much to do with the general quality of the crop that the growing of tomato seed must be done with the greatest care. With this in view, we spare no expense in having our seed produced under the supervision and care of experts in this line. You cannot buy a better seed at any price.

RED ROCK-(Bright red.) A wonderful main crop variety, producing large, solid, bright red tomatoes, free from an excess of water, as smooth as an apple, of superior texture and flavor, an enormous cropper and an excellent shipper. The vine is a vigorous grower which protects the fruit from sunscald. Very good for home or market use, and for canning it is unexcelled.

Postpaid-Pkt. $5 \mathrm{c}$; oz. $25 \mathrm{c}$; $1 / 4$ 1b. $85 \mathrm{c}$; tb. $\$ 3.00$.

CHALK'S EARLY JEWEL-Unsurpassed for the home garden. The plants are of strong, robust growth, with ample foliage to protect the fruits from sun, and not liable to blight. The bright scarlet fruits are smooth, round, very deep, and solidly meaty. It is a heavy cropper, with tomatoes of large size and sweet flavor.

Postpaid-Pkt.5c; oz.30c; 1/4 Ib. $\$ 1.00$; 1b. $\$ 3.50$.

DWARF CHAMPION or TREE-Second early ; medium size; upright grower. A second early, purple-pink variety, especially desirable where garden space is limited. Vine about 2 feet high, vigorous, upright, and compact growing. Fruits medium sized, exceptionally smooth and of very good quality.

Postpaid-Pkt.5c; oz.35c; $1 / 4$ tb. $\$ 1.20 ; 1$ tb. $\$ 4.00$.
SPARK'S EARLIANA-Very early fruit; borne in clusters. A particularly profitable tomato for market gardeners. Vine small but vigorous and productive. Fruits deep scarlet, large, nearly round and exceptionally smooth for so early a vaviety. The fruit is borne in clusters near the base of the plant and the bulk of the crop ripens very early. Valuable for early market; medium size, color a glossy red with purplish tinge.

Postpaid-Pkt.5c; oz.30c; 1/4 1b. $\$ 1.00$; 1b. $\$ 3.50$.

LIVINGSTON'S BEAUTY-The best all-round tomato; exceedingly early, large, smooth and remarkably prolific. It is grown more largely by truckers and market gardeners than any other sort. The variety is of glossy, erimson color, with slight tinge of purple; skin tough; good keeper and shipper.

Postpaid-Pkt. $5 \mathrm{c}$; oz. $25 \mathrm{c} ; 1 / 4$ 1b. $85 \mathrm{c}$ : 1b. $\$ 3.00$.

EARLY ACME-Early and prolific. The fruits are of good size, almost round, and of a beautiful purplish pink color. This sort is always smooth, ripening all over at the same time, juicy and excellent in flavor. A popular one with truckers and market gardeners.

Postpaid-Pkt. 5c; oz. $25 \mathrm{c} ; 1 / 4$ lb. $85 \mathrm{c} ;$ ib. $\$ 3.00$.

JUNE PINK-Extra early; good shipper. An extra early, purplish-pink tomato, similar to the popular scarlet fruited Earliana in growth of vine, shape and size of fruit and time of maturing This is a variety of exceptional va ue to market gardeners.

Postpaid-Pkt.5c; oz.35c; 1/4 1b. $\$ 1.20$; 1b. $\$ 4.00$.

STONE-One of the most valuable all-round sorts on our entire list. The fruit is large, of dark brick red color, fleshy and is not subject to rot like some varieties; nor does it ever have a green core. We can especially recommend it for a late crop, and very desirable for canning.

Postpaid-Pkt. $5 \mathrm{c}$; oz. $25 \mathrm{c} ; 1 / 4$ lb. $85 \mathrm{c}$; th. $\$ 3.00$.

DWARF STONE-Plants are strong and vigorous, of typical dwarf growth. The fruits are produced in many clusters of 3 or 5 tomatoes, averaging $21 / 2$ inches in diameter. They are bright scarlet, very smooth, firm, and solid; and the fruits have solid, meaty center with no core. The quality is unsurpassed.

Postpaid-Pkt.5c; 0z.35c; 1/4 tb. $\$ 1.20$; tb. $\$ 4.00$.

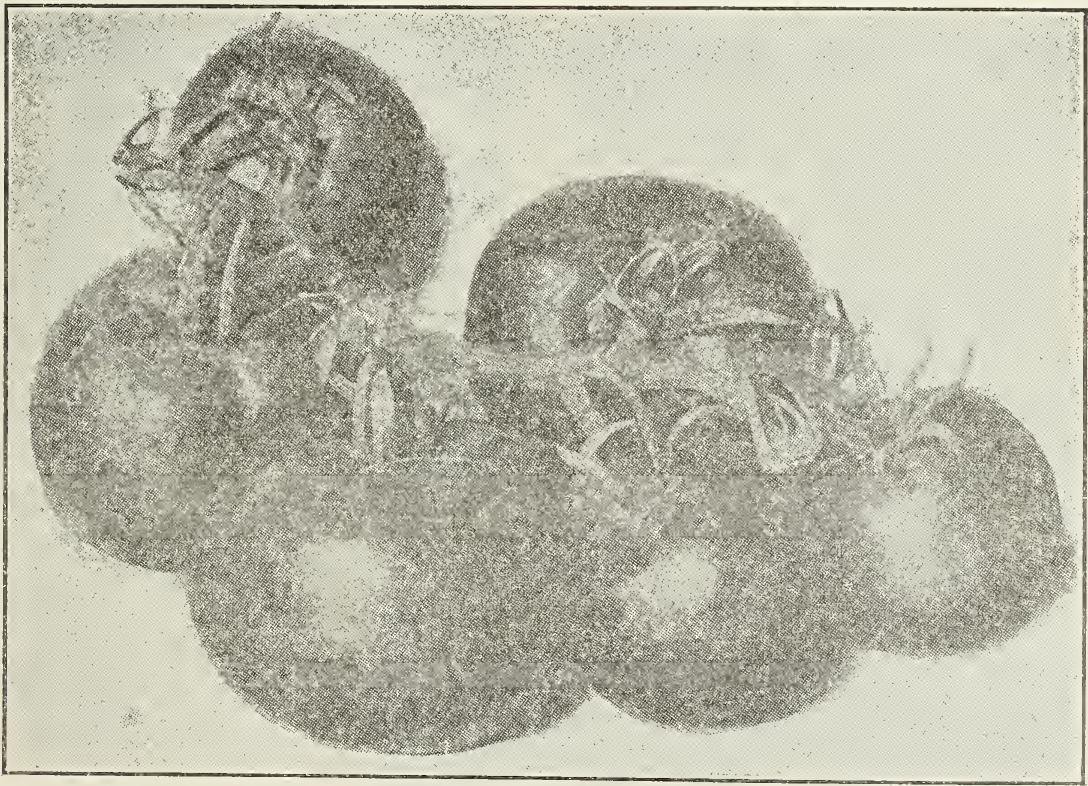

Dwarf Champion or Tree. 


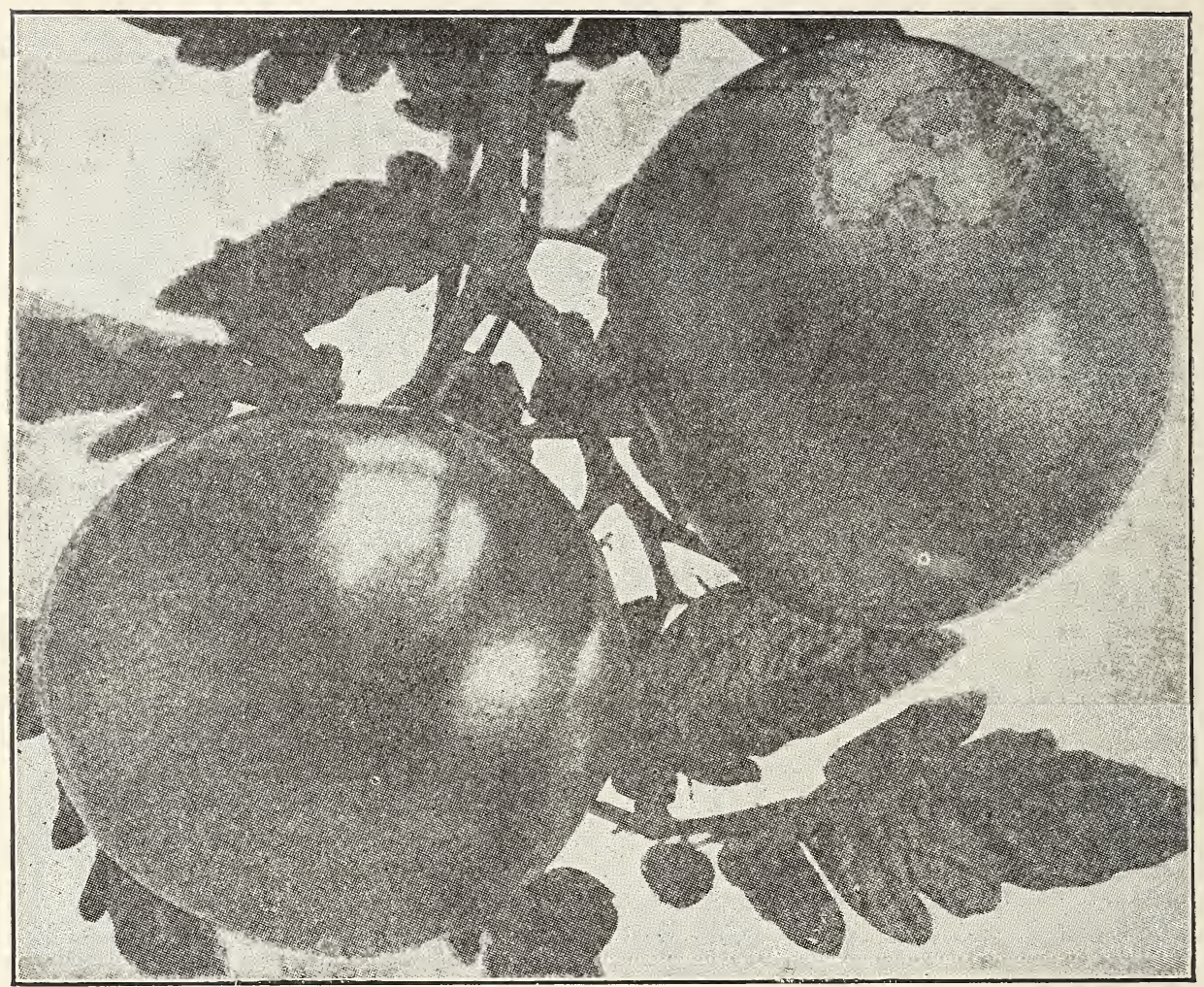

Bonnie Best Tomatoes.

BONNIE BEST-An elegant sort for home market or sh pping on account of its even size and fine keeping qualit es. Large smooth fruit of a rich scarlet red, which is the color demanded by many markets. Fruit smooth, uniform, thick with small core, an excellent tomato for any purpose. Slices exceptionally well. Fruit borne in clusters of 5 or 6 , all ripening evenly together.

Postpaid Pkt. 5c; oz. 25c; $1 / 4$ tb. 90c; tb. $\$ 3.25$.

\section{Ponderosa}

Unquestionably one of the largest tomatoes grown. The vines are vigorous, producing a very large stalk and an unusually thick stem, which is accounted for in the great size and weight of the fruit. It is one of the best flavored sorts grown, almost solid, and contains scarcely any seed. The fruit, when ripe, is cardinal red, and on account of its compact structure will keep longer than any other sort.

Postpaid-Pkt. $5 \mathrm{c} ;$ oz. $60 \mathrm{c} ; 1 / 4$ 1b. $\$ 2$; 1b. $\$ 6.00$.

BRIMMER-This fine variety has the smooth and firm characteristics of Stone, and the size and fine qualities of Ponderosa. It is almost seedless.

Postpaid-Pkt. $10 \mathrm{c} ; 1 / 4$ oz. $25 \mathrm{c} ; 1 / 2$ oz. $45 \mathrm{c} ;$ oz. $75 \mathrm{c}$.

GOLDEN QUEEN or YELLOW TROPHY-A bright orange yellow sort: makes large, handsome smooth tomatoes of fine quality; medium late.

Postpaid-Pkt. $5 \mathrm{c}$; oz. $30 \mathrm{c} ; 1 / 4$ ib. $\$ 1.00$; 1b. $\$ 3.60$

JOHN BAER-A remarkable new variety of the extra early red or scarlet type. Maturing a few days after Earliana, John Baer yields a much heavier crop of more uniform and more attractive tomatoes. It is more profitable to grow than any other early sort.

Postpaid-Pkt. 10c; oz. 30c; 1/4 1b. 90c;1b. $\$ 3.25$
YEI LOW PEAR SHAPED-A small Italian variety, producing its fruit in great clusters, shaped like a pear. Desirable for pickling and preserves. Postpaid-Pkt. $5 \mathrm{c}$; oz. $35 \mathrm{c} ; 1 / 4$ 1b. $90 \mathrm{c}$; 1b. $\$ 3.00$.

TOMATO PLANTS-See page 30 .

\section{TOBACCO SEED}

One ounce will sow a bed of 50 yards.

The seed should be sown as early as possible after danger of frost is over. When the plants are about 6 inches high, transplant into rows 4 or 5 feet apart each way.

Most of the tobacco used is grown in the South. North Carolina and Virginia soils produce tobacco easily and profitably. From a packet to an ounce will supply most anyone. Then why not save money and raise your own tobacco?

WHITE BURLEY-The best filled tobacco known on account of its absorbing qualities. Has a long, wide leaf, very porous, makes bright reds; fine for plug fillers and wrappers. Best adapted to limestone soils.

Postpaid-Pkt. 10c; oz. 60c; 1/4 th. $\$ 2.25$; tb. $\$ 7.00$.

SWEET or LITTLE ORONOKO-Makes the finest fillers and the best natural chewing leaf. Cures a rich red; long and narrow leaf; tough and waxy. Best adapted to rich and gray soils. Postpaid-Pkt. 10c; oz. 60e ; $1 / 4$ 1b. $\$ 2.25$.

CHOICE HAVANA-An Americanized Havana, used for cigar purposes, although sometimes used as a manufacturing sort. Has a very large, long fine quality leaf; very early, making two crops a season in some sections. Best adapted to chocolate or rich gray soils.

Postpaid-Pkt. 10c. 


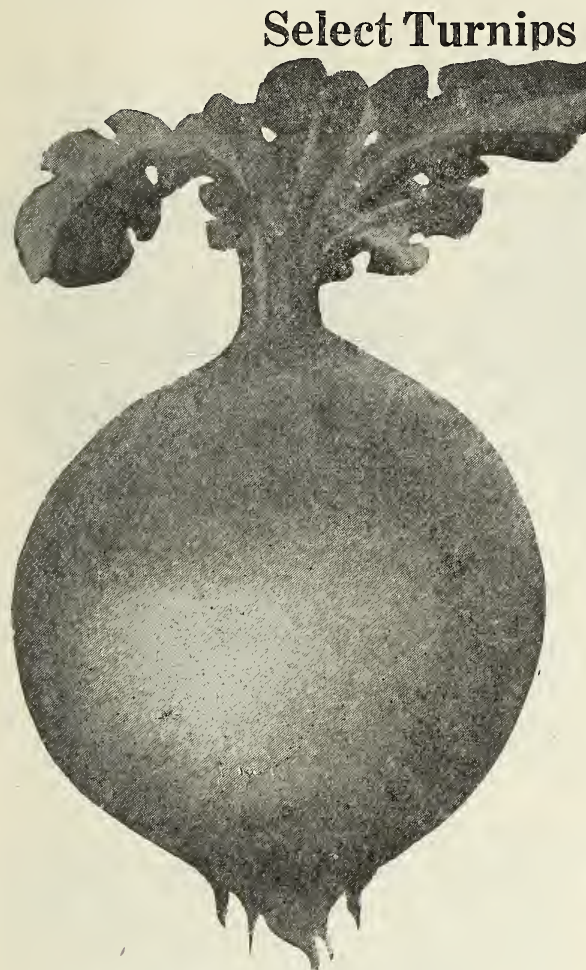

\section{Purple Top White Globe}

Of a perfect shape about 6 inches in diameter, with smooth, white skin; flesh pure white firm and crisp, and of quick growth. A good keeper and is fine for the market.

Postpaid-Pkt. 5c; oz. 10c; 1/4 tb. $25 \mathrm{c}$; tb. $75 \mathrm{c}$.

LONG WHITE or COW HORN-Slender, tapering roots, 6 to 8 inches in length, measuring 11 to 2 inches in diameter. The roots grow half their length above the surface, and are pure white with crisp, sweet flesh. Its matured growth is similar to a cows horn.

Postpaid-Pkt. $5 \mathrm{c}$; oz. $10 \mathrm{c} ; 1 / 4$ 1b. $25 \mathrm{c}$; 1b. $75 \mathrm{c}$.

LARGE YELLOW or AMBER GLOBE - The flesh is beautiful yellow, very fine grained and very sweet. It will grow to a very large size in the South; is one of the very best keepers for winter use.

Postpaid-Pkt. 5c ; oz, $10 \mathrm{c}$; $1 / 4$ 1b. $25 \mathrm{c}$; tb. $70 \mathrm{c}$.

LARGE WHITE GLOBE - Very productive; in good soil roots frequently grow from 10 to 12 tbs. Good for table or stock-feeding.

Postpaid-Pkt. 5c; oz. $10 \mathrm{c}$; $1 / 4$ 1b. $25 \mathrm{c}$; tb. $75 \mathrm{c}$.

EXTRA EARLY PURPLE-TOP MILAN-A white variety, purple top and strap leaf. This, with the White Milan, is the earliest of all Turnips. Remains in good condition a long time.

Postpaid-Pkt. $5 \mathrm{c}$; oz. $15 \mathrm{c}$; $1 / 4$ Ib. $45 \mathrm{c}$; tb. $\$ 1.25$.

EARLY FLAT DUTCH STRAP LEAVED - Matures only a week after the earliest Milan, but keeps much longer in fine condition. The skin is pure white, the flesh is mild, and of best table qualities.

Postpaid-Pkt. 5c; oz. 10c ; $1 / 4$ tb. $25 \mathrm{c}$; $1 \mathrm{~b} .70 \mathrm{c}$.

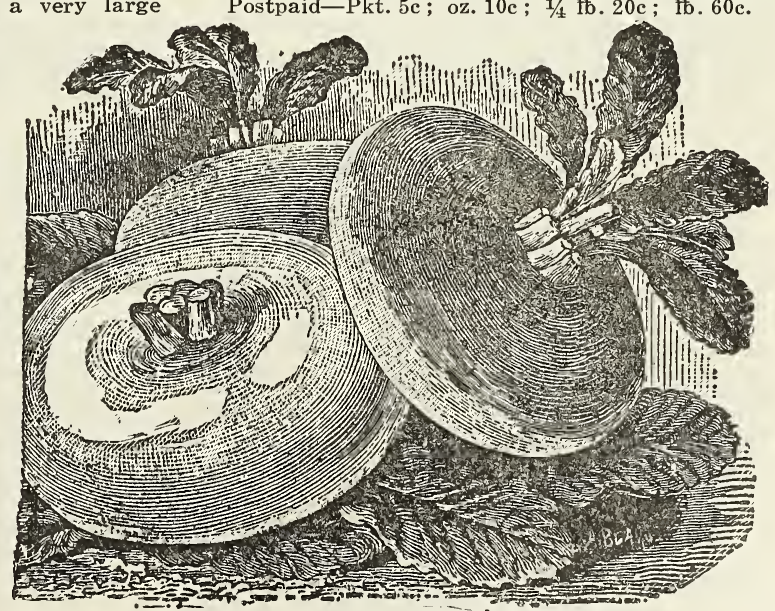

One ounce for $50 \mathrm{ft}$. row; $2 \mathrm{lbs}$. to acre in rows. Culture-Most varieties can be planted in April though for main crop, seed should not be sown until July or August. Plant in rows 12 to 15 ins. apart, covering $1 / 2$ inch deep. When well started, thin out to about 4 of the best plants to a foot of row. Cultivate thoroughly and often. Successive plantings may be made to have fresh turnips throughout the summer.

\section{Red or Purple Top Strap Leaved}

Early; heavy cropper; good keeper. Fine grained and never stringy or tough; leaves are few and upright in growth. Roots flat, medium size, white below ground and purple or dark red above. Flesh white. Roots are in best condition for the table when $2 \frac{1}{2}$ to 3 inches in diameter. When grown much larger they should be fed to stock.

Postpa:d-Pkt. $5 \mathrm{c}$; oz. $10 \mathrm{c} ; 1 / 4$ tb. $25 \mathrm{c}$; 1b. $70 \mathrm{c}$.

EARLY WHITE EGG-A very excellent quality. Nearly oval or egg-shaped. Flesh firm and fine-grained, and of snowy whiteness. Its flavor is of the very best. Particularly desirable for the table. Can be sown as late as middle of August.

Postpa:d-Pkt. $5 \mathrm{c} ;$ oz. $10 \mathrm{c} ; 1 / 4$ tb. 25c; 1b. $70 \mathrm{c}$.

PURPLE TOP YELLOW ABERDEEN - The sweetest of all yellow-fleshed turnips. This famous foreign variety, resembling in shape a finely formed rutabaga, is splendid for stock feeding as well as table use.

Postpaid-Pkt. $5 \mathrm{c}$; oz. $10 \mathrm{c} ; 1 / 4$ tb. $25 \mathrm{c}$; 1b. $70 \mathrm{c}$.

\section{Rutabagas}

Rutabagas, Swedish or Russian Turnips, are extensively grown for a farm crop. The roots are close-grained, hard, and will endure a considerable degree of cold without injury if preserved in pit or cellar during the winter. Rutabagas are superior to any other vegetable root grown for cattle, horses and sheep. The animals thrive and fatten on rutabagas, carrots, and mangels fed in combination with hay.

IMPROVED PURPLE TOP YELLOW-This is the standard all-purpose sort; very hardy, producing well-formed, solid sweet flavored roots. Leaves quite small; very small neck.

Postpaid-Pkt. $5 \mathrm{c} ;$ oz. $10 \mathrm{c} ; 1 / 4$ tb. 25c; tb. $75 \mathrm{c}$

\section{Salad Turnips}

SEVEN TOP-Does not produce a good root, but is extensively grown in the South for the tops, which are used as greens. Very hardy and will grow all winter.

Postpaid-Pkt. $5 \mathrm{c}$; oz. $10 \mathrm{c} ; 1 / 4$ 1b. 20c; 1b. $60 \mathrm{c}$.

DIXIE LAND or SOUTHERN PRIZE-Finest winter turnip grown; identical with the Seven Top, except it makes a very fine, large white turnip.

Postpaid-Pkt. $5 \mathrm{c}$; oz. $10 \mathrm{c} ; 1 / 4$ tb. $20 \mathrm{c}$; 1b. $60 \mathrm{c}$. 


\section{Herbs}

\section{Aromatic and Medicinal}

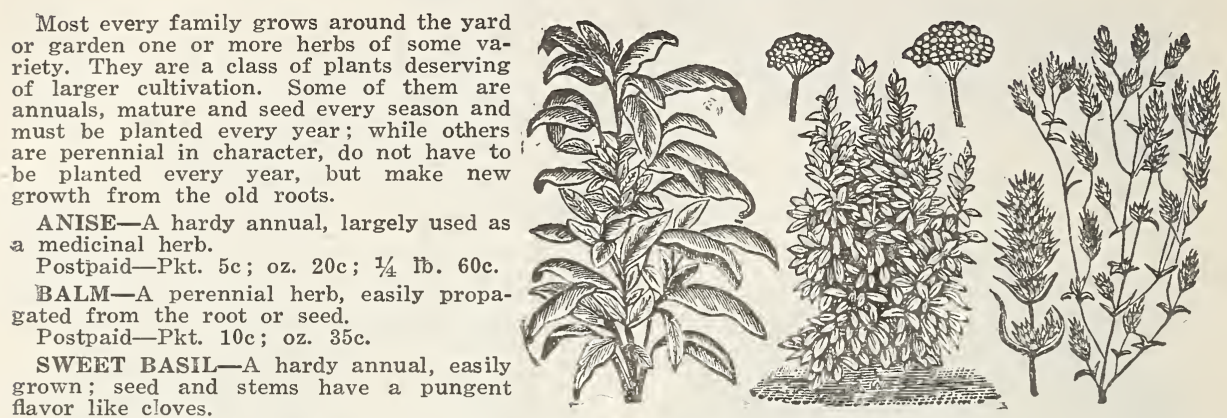

flavor like cloves.
Postpaid-Pkt. 5c; oz. 20c.

CARAWAY-The plant is largely cultivated for its aromatic seed, which are used to a great extent in bread and other pastry.

Postpaid-Pkt. 5c; oz. 15c.

BORAGE-A hardy annual; leaves an agreeable odor and flavor.

Postpaid-Plkt. 5c; oz. 20c.

CATNIP-A hardy perennial; easily propagated

from roots or seed. Valuable medicinal plant.

Postpaid-Pkt. $10 \mathrm{c}$; oz. $50 \mathrm{c}$;

CORIANDER-An annual, easily grown from

seed. It is cultivated for its aromatic seed.

Postpaid-Plkt. 5c; oz. 15c.

DILL-An annual, largely cultivated for its aromatic seed, which are used for flavoring pickles,

etc. Used as a medicine for colic in children.

Postpaid-Pkt. 5c; oz. 15c.

SWEET FENEL - A perennial, grown for its

leaves, which are used for flavoring soups, etc. Postpaid-Pkt. $5 \mathrm{c}$; oz. $15 \mathrm{c}$

HOREHOUND-Valuable perennial herb, large-

ly used in cough medicine.

Postpaid-Pkt. 5c; oz. 30c.

LAVENDER-A hardy perennial, grown mostly

for its perfume.

Postpaid-Pkt. 5c; oz. $30 \mathrm{c}$.

SWEET MARJORAM-A tender perennial, used

for its delicate flavor.

Postpaid-Pkt. 5c; oz. 50c.

ROSEMARY-A hardy perennial, grown for its

fragrant odor and aromatic, bitter taste.

Postpaid-Pkt. 5c; $1 / 2$ oz. $50 \mathrm{c} ;$ oz. $85 \mathrm{c}$.

SAGE-A hardy perennial, widely grown from

seed. Grown for flavoring meats, sausages, etc.

Postpaid-Pkt. 5c; oz. $50 \mathrm{c} ; 1 / 4$ 1b. $\$ 1.75$.

SUMMER SAVOY-An annual, grown largely for flavoring soups, etc.

Postpaid-Pkt. 5c; oz. $30 \mathrm{c}$

TANSY - A hardy perennial, grown for its medicinal uses.

Postpaid-Pkt. 5c; oz. 25c.

THYME - A perennial, grown both for its medicinal virtues and its flavoring qualities.

Postpaid-Pkt. 5c; $1 / 2$ oz. $50 \mathrm{c}$; oz. $85 \mathrm{c}$.

\section{Gourds}

TENDER ANNUAL CLIMBERS-Plant in hills after the danger of frost is past, and cultivate as you would cucumbers or squash, leaving 2 or 3 plants to a hill. They may be trained over lattice work, fences, to poles, etc. Dried shells of these fruits are quite useful for household purposes.

DIPPER GOURD-Makes a light, convenient dipper. When grown on the ground, the stems will be curved, while if raised as a climbing vine the weight of the blossom end will cause the blossom end to grow straight.

Postpaid-Pkt. 10c; oz. 25c.

SUGAR TROUGH GOURD-Grows very large. The shell, when dried, is thick and hard, extremely light, but very durable. Used for buckets, large dishes and many other household purposes.

Postpaid-Pkt. $10 \mathrm{c}$; oz. 35c.

JAPANESE NEST EGG GOURDS-Grows almost uniformly to the size, color and shape of a hen's egg. The shells are hard and make the very best nest eggs. They are also useful for stocking darners.

Postpaid-Pkt. 10c; oz. 35c.

CHOICE MIXED GOURDS-Pkt. 5c; oz. 25c.

\section{Summer-Flowering Bulbs and Roots}

There is nothing in floriculture which, to the amateur will be attended with as great satisfaction or give as grand results, as the cultivation of this class of flowering plants. Set out in early spring, they bloom all summer. No matter if planted solely to beautify the home grounds or cultivated by the small boy as his first step to profitable floriculture, the returns will be equally gratifying. They are of easiest culture, inexpensive, and require scarcely any care. Most of these bulbs should be taken up before severe frost and stored away in a frost-proof cellar, if possible in dry sand, to preserve for replanting the following spring.

\section{PEONIES}

Peonies may be planted in spring as soon as the frost is out of the ground. But only two or three inches of soil over the crown, deep planting is often cause of shy blooming. Do not transplant for at least five years. We have large clumps in the following colors: Red, Pink and White, $40 \mathrm{c}$ each; 3 for $\$ 1.15$ postpaid.

Write for our Fall Bulb Catalogue.

THRIFTY CANNA ROOTS

AUSTRIA-Lemon Chrome yellow, green foliage, 5 feet.

CHAS. HENDERSON - Crimson; green foliage, $41 / 2$ feet.

KING HUMBERT-King among cannas, coppery scarlet, bronze foliage, 4 feet.

YELLOW KING HUMBERT - Golden yellow ; dotted red, green foliage, $4 \frac{1}{2}$ feet.

$15 \mathrm{c}$ each; 3 for $40 \mathrm{c} ; \$ 1.50$ per dozen.

HARDY CHRYSANTHEMUMS

Pink, White, Red, Yellow.

20 c each; 3 for 55 c; $\$ 2.10$ per dozen.

(Continued on next page.) 


\section{Dahlias}

The principal requirements of the Dahlia are a sunny location, liberally manured soil, plenty of room, and the surface kept light by hoeing or cultivating; when plants are well advanced, feed with pulverized manure. We carry the following double sorts:

A. D. LIVONIA-(Show.) Clear cerise pink quilled petals. Great favorite.

WHITE SWAN-(Show.) Pure White. Very large.

QUEEN VICTORIA - (Show.) Rich Golden yellow, quilled petals.

RED HUSSAR-(Show). Richest dazzling cardinal red.

LYNDHURST-Decorative. Brightest Vermillion.

JACK ROSE-A double decorative Dahlia of immense size and rare beauty, rich velvety crimson.

Price 25c each; 3 for $65 \mathrm{c} ; \$ 2.25$ per dozen.

By mail-30c each; 3 for $75 \mathrm{c}$; $\$ 2.35$ per dozen.

MELODY-(Decorative). "A lovely flower without a fault."

One of the finest, being of splendid regular form with full high center and reflexed outer petals. Color clear canary yellow, tinting to creamy white at tips; an effect so delicate and pleasing as to suggest the name.

Strong roots, $35 \mathrm{c}$ each; 3 for $\$ 1.00 ; \$ 3.00$ per dozen.

By mail-40c each; 3 for $\$ 1.10 ; \$ 3.20$ per dozen.

MRS. ROOSEVELT-Lovely shade of enchantress pink,

flowers of a giant size, borne on long stems, very vigorous.

50c each; 3 for $\$ 1.35 ; \$ 4.75$ per dozen.

By mail-55c each; 3 for $\$ 1.45 ; \$ 4.95$ per dozen.

VARIEGATED LISZT-Dark Oriental red, with yellow tips and markings. A superior variety for decorations, especially where a bronzy effect is wanted (double show).

Price-25c each; 3 for 65c; $\$ 2.25$ per dozen.

By mail-30c each; 3 for $75 \mathrm{c} ; \$ 2.45$ per dozen.

CANARY-Peony flowered, pure canary yellow of very largest size; an early, free and continuous bloomer on long slender stems.

30 c each; 3 for 85c; $\$ 3.25$ per dozen.

By mail-35c each; 3 for $95 \mathrm{c} ; \$ 3.45$ per dozen.

BARON G. DE GRANCY PEONY-Flower almost pure white; a flower of excellent type, perfect form and purity of color.

$30 \mathrm{c}$ each; 3 for $85 \mathrm{c}$; $\$ 3.25$ per dozen

By mail-35c each; 3 for $95 \mathrm{c} ; \$ 3.45$ per dozen.

\section{CACTUS DAHLTAS}

FAIRY QUEEN-Pure white of beautiful form, very long, narrow, quilled in curved petals.

BRUNHILDE-Deep cerise pink, tinting to creamy pink at center. Flowers keep long time after cutting.

GENERAL BULLER RICE-Velvety maroon, shading to crimson tipped white.

LIBELLO BEAUTIFUL ASTER-Purple, very effective.

FAUNUS-Yellow, shading to rosy scarlet, long pointed petals, a beautiful flower.

$25 \mathrm{c}$ each; 3 for $65 \mathrm{c}$; $\$ 2.25$ per dozen.

By mail-30c each; 3 for $75 \mathrm{c} ; \$ 2.45$ per dozen.

\section{SINGLE CENTURY DAHLIAS}

ROSE PINK-The largest and best deep pink.

20th CENTURY-Early in season, a rosy crimson, shading to white tips, by October nearly white with pink blotch in center.

ECKFORD CENTURY-Immense flower, white suffused pink spotted and penciled crimson.

YELLOW CENTURY-Magnificent yellow of largest size.

CATCUS and CENTURY DAHLIAS-25c each; 3 for $65 \mathrm{c}$;

$\$ 2.25$ per dozen.

By mail-30c each; 3 for $75 \mathrm{c}$; $\$ 2.45$ per dozen.

\section{Tuberoses}

Delightfully fragrant; fine for bouquets. Plant when the ground gets warm or start in pots or in hot-beds and set outside in May. Give plenty of water.

EXCELSIOR PEARI-Mammoth Bulb, 12c each ; 4 for $40 \mathrm{c}$; dozen, $\$ 1.15$, postpaid. By Express, $10 \mathrm{c}$ each; 4 for $35 \mathrm{c}$; dozen, $\$ 1.00 ; 100$ for $\$ 7.00$.

SINGLE or ORANGE FLOWERED-Blooms earlier than the Excelsior Pearl, single flower, orange tinted.

Price- $\$ 1.00$ per dozen. If by mail, $\$ 1.10$ per dozen.

\section{Caladiums}

ELEPHANT'S EAR-A very effective plant for beds or groups, especially in lawns. To have the best results they must have an abundance of water and plenty of rich manure. When full grown, they stand 6 to 8 feet high, and bear immense light-green leaves 3 to 4 feet long 2 to $21 / 2 \mathrm{ft}$. wide.

FIRST SIZE BULBS-11 to 13 inches in circumference. Postpaid-30c each; $\$ 3.10$ per dozen.

SECOND SIZE BULBS-8 to 11 inches in circumference.

Postpaid-20c each; $\$ 2.10$ per dozen.

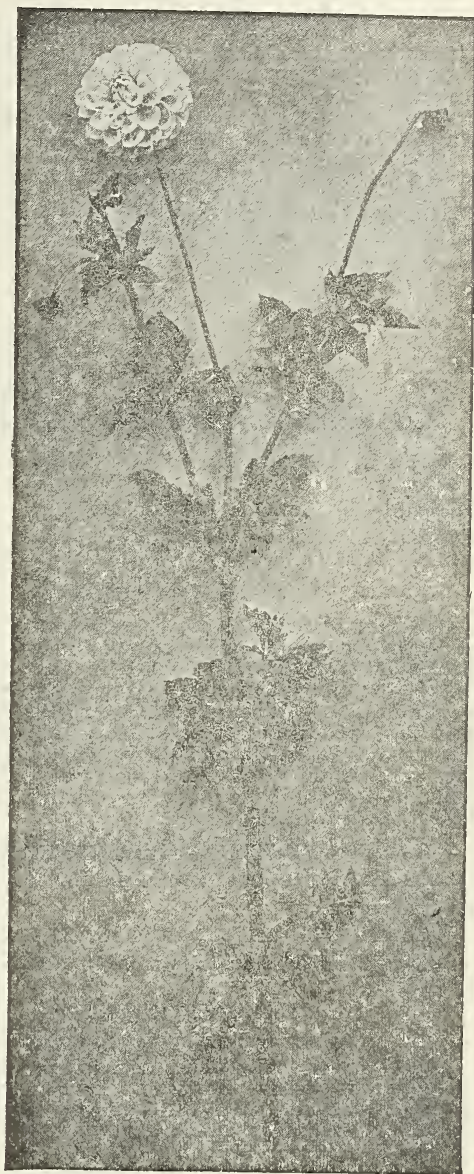

MELODY, DECCORATIVE DAHLIA

\section{Gladiolas}

Attractive and easily grown summer bloomers, giving gorgeous effects in mixed beds, massed in large clumps and when planted in clusters among shrubs. For a succession plant at intervals from April till June. Plant 6 inches apart and 4 inches deep.

MIXED GLADIOLAS-Our mixtures sover a wide range of colors. Extra large Postpaid-7c each; doz 65c; 100,\$4.40.

BARON J. HULOT-Dark velvety purple.

MRS. FRANK PENDLETON Salmon pink, with rich carmine blotches in the throat.

MRS. WYATT-American beauty rose color.

PANAMA-Rich Salmon pink; large flowered.

AMERICA-Soft lavender pink.

MRS. FRANCIS KING - Brilliant flaming pink blazed with vermillion red. CHICAGO WHITE-White, lavender marking in throat.

SCHWABEN-Clear canary yellow, shading to a soft sulphur yellow.

PRINCEPS - Scarlet with white throat; very attractive.

PRIMULINUS HYBRIDS - Yellow and orange shades.

Postpaid-10c each; dozen $\$ 1.10$. 


\section{Hardy Vegetable and Flower Plants}

The demand for our hardy plants has been inceasing each year and every day we receive let ters of approval or words of appreciation for the plants and bulbs purchased from us last year.

These plants are all grown from the very finest strain of seeds and under the supervision of a gardener and florist that has had many years experience. We are confident that you will be pleased not only with out plants but the service we give you. In as far as possible we make ship- ment the same day order is received. Under normal conditions the plants we ship you will produce the finest vegetable and flowers.

We will accept orders for immediate or future delivery at the prices quoted, subject to crop failures and stocks unsold. Please send remittance with order as we will positively ship no plants C. O. D. We guarantee safe delivery except where incorrect address is given by the customer.

\section{No Plants will be Shipped C. O. D.}

\section{VEGETABLE PLANTS}

\section{Asparagus, Double Rooted}

BARR'S MAMMOTH, or CONOVER'S COLOSSAI.

Postpaid-50 for $85 \mathrm{c} ; 100$ for $\$ 1.50$.

Express-50 for $75 c ; 100$ for $\$ 1.35 ; 1,000$ for $\$ 11.00$

\section{Cabbage Plants}

Our own plants will not be ready until the first of April; however, we can supply Frost Proof Cabbage Plants of good quality in any quantities. These are hardened and will usually withstand severe freezes. When Frost Proof Plants arrive they appear withered and lifeless; however, a large percentage live and thrive after being properly set. Both Frost Proof and our own plants will be grown from superior strains of Long Island grown cabbage seed.

FR OST PROOF CABBAGE-Early Jersey

Wakefield, Charleston Wakefield, or Henderson's Early Summer.

Postpaid-100 for 30c; 1,000 for $\$ 2.15$.

Express- $\$ 2.00$ for 1,000 ; 5,000 for $\$ 1.75$ per 1,000 .

\section{OUR OWN PLANTS}

Ready from April to October

Early Jersey Wakefield, Charleston Wakefield, Henderson's Early Summer, Early Drumhead, Late Drumhead, Danish Ballhead, Early Flat

Dutch or Late Flat Dutch.

Postpaid-100 for $30 \mathrm{c} ; 1,000$ for $\$ 2.15$.

Express-1,000 for $\$ 2.00 ; 5,000$ for $\$ 1.75$ per 1,000

\section{Egg Plant}

New York Improved Spineless, Black Beauty, Florida Big Bush.

Postpaid-(Double Rooted) Doz. 50c; 100, $\$ 3.25$. Express-(Double Rooted) Doz. 45c; 100, $\$ 3.00$. Postpaid(Potted) Doz. 75c.

Express-(Potted) Doz. 60c; 100, \$4.25.

\section{Tomatoes}

Dwarf Champion, Dwarf Stone, Matchless, Brimmer, Ponderosa, Bonny Best, Acme, Stone, Livingston's Beauty, Chalk's Early Jewel, Spark's Earliana, June Pink, Golden Queen, Red Rock.

Postpaid-(Double Rooted) Doz, 40c; 100, $\$ 3$.

Express-(Double Rooted) 100, $\$ 2.75 ; 1,000 \$ 20$. Postpaid-(Potted) Doz. 65c; $100, \$ 4.25$.

Express-(Potted) $100, \$ 4.00 ; 1,000, \$ 38.00$.

\section{Cauliflower}

Snowball, Dry Weather and Extra Early Erfurt. Postpaid-(Double Rooted) Doz. 30c; 100, \$2.25. Express-(Double Rooted) 100 for $\$ 2.00$.

Postpaid-(Potted) Doz. 60c.

Express-(Potted) 100 for $\$ 4.00$.

\section{Celery}

White Plume, Golden Self-Blanching, Giant Pascal, Winter Queen.

Postpaid-(Double Rooted) 50 for $70 \mathrm{c} ; 100, \$ 1.25$.

Express-(Double Rooted) 100 for $\$ 1.10 ; 1,000$ for $\$ 10.00$.

HORSE RADISH ROOTS

Postpaid-Per dozen, 20c; per 100, $\$ 1.25$.

\section{Sweet Pepper}

Ruby King, Chinese Giant, Bell or Bull Nose, Pimento and Golden Queen.

Postpaid-(Double Rooted) Doz. 45c; 100, \$3.25.

Express-(Double Rooted) 100, $\$ 3.00 ; 1,000$, $\$ 20.00$.

Postpaid-(Potted) Doz. 65c; $100, \$ 5.00$.

Express-(Potted) $100, \$ 4.50 ; 1,000, \$ 42.00$

Long Red Cayenne, Hot Pepper.

Postpaid-(Double Rooted) Doz. 45c; $100, \$ 3.25$.

Express-(Double Rooted) $100, \$ 3.00 ; 1,000, \$ 20$.

Postpaid(Potted) Doz. 65c.

Express-(Potted) 100, $\$ 4.50$.

\section{Sweet Potatoes}

Nancy Hall, Southern Queen, Pczto Rico.

Postpaid-100 for $45 \mathrm{c} ; 1,000$ for $\$ 3.75$.

Express-1,000 for $\$ 3.50 ; 5,000, \$ 3.25$ per 1,000 .

\section{FLOWER PLANTS}

\section{CLIMBING ROSES}

$2 \frac{1}{2}$ inch pots

Following named varieties

American Beauty

American Pillow

Crimson Rambler

Dorothy Perkins, Pink

Dorothy Perkins, White

Etoile de France, Crimson

Gardinia, Yellow

Lady Gay, Soft Pink

Wichurana, White

Climbing Roses

(2 year Field Grown)

Names and Colors as above $50 \mathrm{c}$

Baby Rambler Roses

( $2 \frac{1}{2}$ inch pots)

Pink, White and Red

$25 \mathrm{c}$

\section{HYBRID TEA or EVERBLOOMING}

$2 \frac{1}{2}$ inch pots

Doz.

Postpaid

$\$ 2.50$

2.50

2.50

2.50

2.50

2.50

2.50

2.50

2.50

5.00

2.50
Each

Doz.

Antonie Riverie, Pink

Hadley, Dark Red

Hoosier Beauty, Red
Etoile de France, Crimson

Etoile de Lyon

Kaiserine A Victoria, White

Maman Cochet, White

Maman Cochet, Pink

Ophelia, Fancy

Radiance, Red

Sunburst, Yellow

Baby Rambler Roses

(2 year field grown)

Postpaid

Postpaid

Pink, White and Red

$\begin{array}{rr}25 \mathrm{c} & \$ 2.50 \\ 25 \mathrm{c} & 2.25 \\ 25 \mathrm{c} & 2.50 \\ 25 \mathrm{c} & 2.50 \\ 25 \mathrm{c} & 2.50 \\ 25 \mathrm{c} & 2.50 \\ 25 \mathrm{c} & 2.50 \\ 25 \mathrm{c} & 2.50 \\ 25 \mathrm{c} & 2.50 \\ 25 \mathrm{c} & 2.50 \\ 25 \mathrm{c} & 2.50 \\ & \\ & \\ 50 \mathrm{c} & 5.00\end{array}$




\title{
Flower Plants
}

\author{
No Plants Will Be Shipped C. O. D.
}

Our Hardy Perennial Plants and our Annual Bedding Plants gave the utmost satisfaction to all of our customers last season and we had many repeat orders, with expressions of pleasure. These plants are grown in pots and when they reach

\section{Hardy Perennial Plants}

$2 \frac{1}{2}$ inch Pots

Postpaid- $\$ 1.25$ per dozen.

Express- $\$ 1.00$ per dozen.

Field Grown Clumps

4 inch Pots

Postpaid-\$1.85 per dozen.

Express- $\$ 1.50$ per dozen.

AGROSTEMMA, Crimson and White.

ABELIA, Grandiflora.

AGERATUM.

ALYSSUM, Sweet.

ACHILLEA, White and Pink.

ANCHUSA, Italica.

AQUILEGIA or COLUMBINE (Four Varieties).

ARABIS or ROCK CREST.

BELLIS PERENIS (Double Daisy).

CAMPANULA (Canterbury Bell) all colors, double and single.

CARYOPETERIS, Blue Spyrea.

CENTAUREA.

CERASTIUM (Snow in the Summer).

CHRYSANTHEMUM (Red, White, Pink and Yellow.)

CINERARIA

CLEMATIS (Paniculata).

COREOPSIS.

COWSLIPS.

DAISY (Shasta).

DELPHINIUM

Belladonna (light blue).

Bellamosa (dark blue).

Chinese Blue.

Formosum (blue).

Double Flowering Mixed.

Gold Medal Hybrids.

DIANTHUS-Pinks, Four Colors.

DIGITALIS (Foxglove) Six Colors.

GAILIARDIA (Grandiflora Compacta).

GYPSOPHILA (Baby Breath) Pink and White).

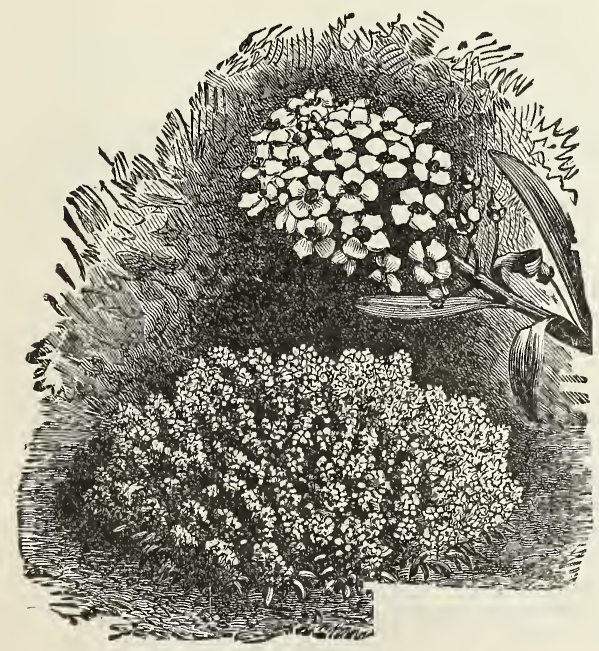

LITTLE GEM SWEET ALYSSUM you they are in a strong, healthy condition, ready to be repotted or set out doors.

All stocks quoted subject to change and unsold. Send your order early for future shipment.
HELIANTHEMUM (Sun Rose).

HELIANTHUS, Mixed.

HELIOPSIS, Pitcheriana.

HOLLYHOCKS, (Double Salmon, Rose, Bright rose, Red, Maroon, Yellow and New Port Pink.) LYTHYRUS LATIFOLIUS (White Pearl).

LAVENDULA (True Lavender).

LINUM, Perenne (Blue).

LOBELIA (Cardinal Flower).

LUPINUS (Blue and Rose).

MATRICARIA, Feverfew (Rose and White)

MYOSOTIS, (Forget-Me-Not).

PACHYSANDRA, Japanese Sperge.

POLYGONUM, Vine.

POPPY, Oriental and Oriflamme.

SALVIA, Azure Grandiflora Farinacea, Blue. STATICE.

STOKESIA, Cyanea, blue.

SWEET WILLIAM (White, New Port Pink, Scarlet Beauty and Mixed).

TRITOMA, Hybrida or Ret Hot Poker.

VERONICA, Longifolia.

\section{Annual Bedding Plants}

Dozen

Postp'd

AGERATUM

AMARANTHUS

ANTIRRHINUM (Snapdragon)

Separate Colors or Mixed -_-_-_-_ $75 \mathrm{c}$

ASPARAGUS, Plumosus Nanus

ASTERS, Best Varieties

BABY BREATH -

BACHELOR'S BUTTON --

BEGONIA, Ever Blooming

White, Pink and Red ---

CALENDULA

CANDYTUFT --

CANNA (Separate Colors)

CARDINAL CLIMBER (Vine) ------------75c

COBAEA SCANDENS (Vine) -

COLEUS, Separate or Mixed Colors

DELPHINIUM -_-

FERNS :

Boston $\$ 1.00$

John Wanamaker - 1.00

Maiden Hair

Ostrich Plume --- 1.00

Philadelphia Lace -1.00

Plumosus Nanus - 1.00

Roosevelt -

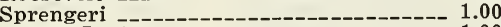

Teddy Junior

FERNS, Table, any Variety --_-_-_-_--- 1.00 GERANIUM HELIOTROPE ----_---_-------- $75 \mathrm{c}$

IMPATIENS SULTANI --_--_--_-_-_-_--75c

LOBELIA

MARIGOLD (African and French) MIGNONETTE -_MOON FLOWER (Vine) -

PANSY, Double Rooted ------------ $40 \mathrm{c}$

PANSY, Potted

PETUNIA, Single or Double (any color) -----75c PHLOX DRUMMONDI -_-_-_SALVIA SPLENDENS --_--SALVIA AMERICA -SALVIA, EDWARD P. (new) VERBENA ZINNIA, Large Double ----------- $65 \mathrm{c}$

Various Vines for Porch and Baskets_-_----75c 


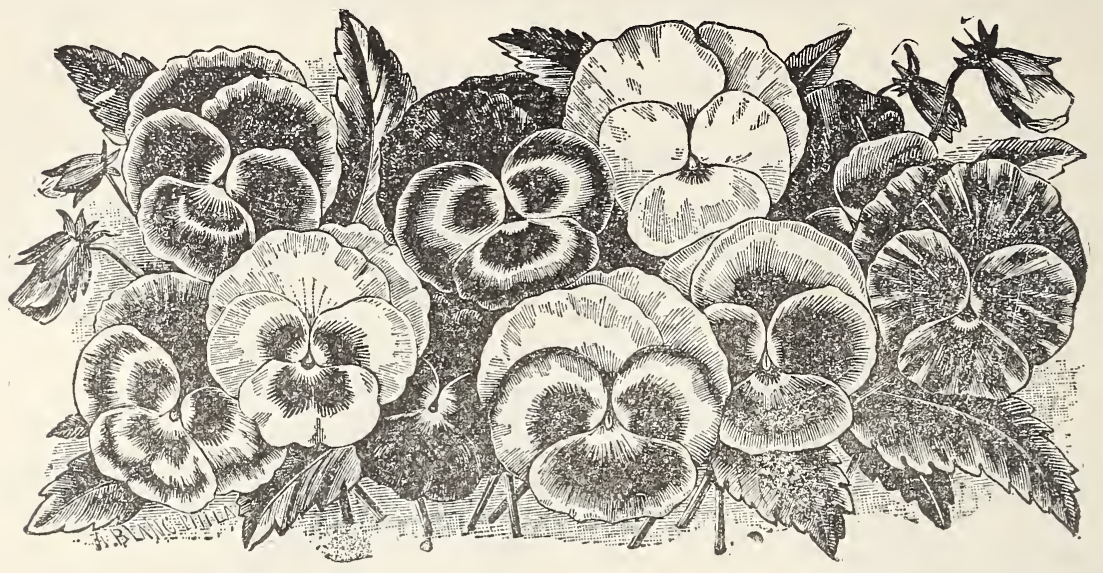

\section{Selected Flower Seed}

General Cultural Directions for Flower SeedsMost flower seeds germinate well in a rather light sandy loam, exposed to the sun, while a few are benefitted by partial shade, and some do best with an element of clay finely mixed with the soil. Nearly all hardy seeds vegetate better when planted in early spring as soon as the soil can be worked fairly and easily and has become warm.

A general rule for the seed-bed is to have the soil rich, level and worked finely. Sow the seed evenly in the rows, cover with the finest of soil, about three times the diameter of the seed, and press the soil firmly over the seed. The soil should never become dry after the seeds have swelled, for if it does, they will be pretty sure to fail.

After the seeds are up, care must be taken to give them plenty of air and moisture, and yet not too much water, or they will "damp-off" (rot at the top of the ground). As soon as the second leaves are well out, the seedlings should be put into pots or new boxes. When finally transplanted to the bed or border, water frequently until established.

ABRONIA - Sand Verbena. (Umbellata- A trailing plant which thrives in poor soil. Its fragrant pink flowers borne in clusters all summer.

Price-Pkt. 5c.

A B U T I L O N-Flowering Maple. (Mixed)Shrubby plants, suitable for house, greenhouse, or garden. $4 \mathrm{ft}$. Drooping, bell-shaped flowers of various colors.

Price-Pkt. $10 \mathrm{c}$.

A D L U M I A - Allegheny Vine. (Cirrhosa)Climber: $15 \mathrm{ft}$. Feathery foliage: pink flowers in mid-summer. Desirable for covering trellises, tree stumps, etc.

Price-Plkt. 10c.

AGERATUM-Half hardy annual. Grows wel and blooms continually until destroyed by frost. Valuable for cut flowers. Tall sorts are effective grown with Alyssum, Candytuft, etc. Dwarf varieties are suitable for edgings.

Imperial Dwarf-Blue 9 to 12 inches. Pkt. $5 \mathrm{c}$; $1 / 2$ oz. $40 \mathrm{c}$.

Imperial Dwarf-White 9 to 12 inches. Pkt. $5 \mathrm{c}$; $1 / 2$ oz. $40 \mathrm{c}$.

ACHILLEA-Milfoil or Yarrow. ("The Pearl") $-1 \frac{1}{2} \mathrm{ft}$. Double white daisy-like flowers in summer and fall.

Price-Pkt. 10c.
A L Y S S U M - Hardy annual of dwarf habit, blooming until killed by frost. Fine for beds, borders, and vases. The snow-white flowers are fragrant and lasting. For edging to beds or borders, sow thickly to form masses. Cut flowers freely and others will take their places.

Maritimum-(Sweet Alyssum)-1 foot.- PricePkt. $5 \mathrm{c} ; 1 / 2$ oz. $20 \mathrm{c}$; oz. $35 \mathrm{c}$.

Little Gem-(Carpet of Snow) -6 in. Best for pots. Pkt. $5 \mathrm{c}$; $1 / 4$ oz. $25 \mathrm{c}$; oz. $45 \mathrm{c}$.

Lilac Queen-Lavender Lilac.

Pkt. $5 \mathrm{c} ; 1 / 1 \mathrm{oz} .25 \mathrm{c}$; oz. $45 \mathrm{c}$.

AMARANTHUS - Caudatus. (Love-Lies-Bleeding) $-3 \mathrm{ft}$. Brilliant foliage; dark red, drooping spikes. Price-Pkt. $5 \mathrm{c} ; 1 / 4$ oz. $20 \mathrm{c}$.

Tri-Color. (Joseph's Coat)-Foliage crimson yellow and bronze. Price-Pkt. 5c; $1 / 2$ oz. $10 \mathrm{c}$.

Fine Mixed-Above and others. Price-Pkt. $5 \mathrm{c}$; $1 / 4$ oz. $10 \mathrm{c}$.

AMPELOPSIS - Boston Ivy. (Vechti)-Rapidgrowing hardy vine. It adheres firmly to stone, brick, or wood. Foliage turns to scarlet in autumn.

Price-Pkt. 5c; $1 / 2$ oz. $15 \mathrm{c}$.

Anemone Јаропica - Japanese Windflower Snowy White. Pkt. $5 \mathrm{c} ; 1 / 4$ oz. $25 \mathrm{c} ;$ oz. $45 \mathrm{c}$.

ANTIRRHINUM-Snapdragon. $11 \%$ to $3 \mathrm{ft}$. Dark, glossy leaves, and curiously shaped, showy colored flowers with spotted throats. Snapdragons blossom the first year, if seed is sown early. Slightly covered with leaves, they survive our winters. Succeed best in rather light soil.

Tall Sorts-Mixed. Pkt. 5c; $1 / 4$ oz. 25c.

Dwarf Sorts-Mixed. Pkt. 5c; $1 / 4$ oz. 25c.

A Q U I L E G I A-Columbine. 2 to $3 \mathrm{ft}$. Wellknown and favorite plants for the garden border especially suitable for shady places. Are easily grown, soon form large clumps, and bloom from May until August.

Canadensis-Scarlet. and yellow; native. PricePkt. 5c.

Chrysantha-Long-spurred, yellow, single. Price -Pkt. 5c.

Coerulea-(Rocky Mountain Columbine). Sepals deep blue, petals white. Price-Pkt. 10c.

Double Mixed-Price-Pkt. $5 \mathrm{c} ; 1 / 4$ oz. $30 \mathrm{c}$.

Vulgaris-Single, mixed. Pkt. $5 c ; 1 / 4$ oz. 25 c. 


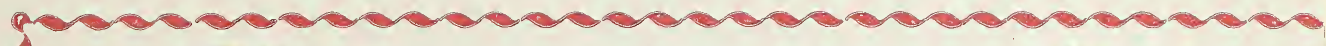

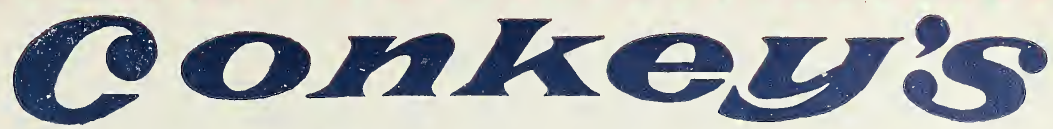

THE ORIGINAL

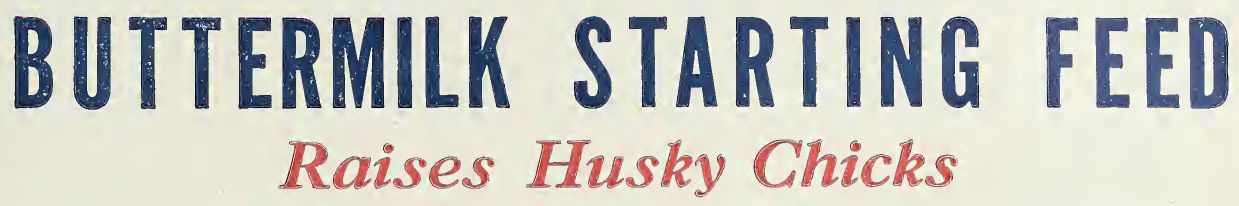

A Ready Prepared Mash for baby chicks and all self-feeding young fowls. This remarkable feed-originated by Conkey and prepared through processes controlled and used exclusively by Conkey is a complete ration-containing all the elements needed for safely starting baby chicks, ducklings, goslings, poults, guineas, pheasants, etc.

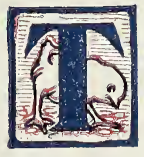

HIS superior chick mash was the first commercial poultry feed containing buttermilk - that is why we call it the only ORIGINAL buttermilk starting feed.

Conkey's did not "just happen" -it is a scientifically-balanced feed as clean and wholesome and a conscientiously-prepared as "infant food." Selected, plump grains, ground to proper fineness, are combined with other ingredients so as to make the feed readily digestible, palatable and nutritious. TASTE it, SMELL it, that's the way to judge a chick feed.

Conkey's carries buttermilk in just the right proportion as an aid in prevention of bowel troubles, White Diarrhea, "leg weakness," etc. The buttermilk is Semi-Solid buttermilk, blendec with the other ingredients by the ORIGINAL process in such a way as to preserve the appetizing, tonic, and other properties of the newlychurned product.

The moisture in the buttermilk is drawn off by the exclusive Conkey process in such a way as not to subject it to the terrific heat usually required in "drying" buttermilk.

Lactic acid in buttermilk is described as an "Intestinal broom" which sweeps away unfriendly bacteria and disease germs in the delicate digestive tract. Buttermilk is also rich in cne of the vitamines necessary to growing birds. It is a wonderful appetizer, aid to digestion and flesh builder.

However, it is not the buttermilk nor the other ingredients alone that causes people to declare that their chicks grow twice as fast on Conkey's.
GUARANTEED ANALYSIS

Crude Protein, 12\%; Crude Fibre, 4\%; Crude Fat 3\%; Nitrogen Free Extract, $56 \%$; Carbohydrates, $60 \%$.

\section{Ingredients}

Semi-Solid Buttermilk, pinhead oatmeal, a special wheat middlings whole corn meal, corn feed meal and granulated bone.

It is not the buttermilk alone that protects the chicks from disease during the first critical eight weeks. The secret is in the combination of these materials by the Conkey method-the balancing of the ration, as Conkey alone knows how.

Don't be influenced by "cheaper" imitations labeled "buttermilk" - that word may be used to deceive unwary buyers-to cover up a multitude of "sinful" grains, mill sweepings, poisonous weed seeds, musty screenings, worthless by-products, or other poor material havinz little or no nutritive value.

Conkey's is so palatable that one poultryman said it ought to be used for "breakfast food." One woman wrote: "My chicks just love Conkey's. It is so tasty, and my, how they do grow! Better still, we didn't have a single loss in the present hatch, no White Diarrhea or other bowel troubles like before we began using Conkey's."

\section{FEED IT FIRST 8 WEEKS}

Conkey's is all the chicks need the first eight weeks except greens, charcoal, grit, clean water and some fine scratch grains in the litter for exercise. Give grit and water from the start. During the second week add green stuff and in the fourth week finely cracked chick grains, like Conkey's Chick Grains.

Packed in convenient sizes from $21 / 2$ lbs. up Buy $11 / 2$ lbs. for every chick. Ask or write for prices. 

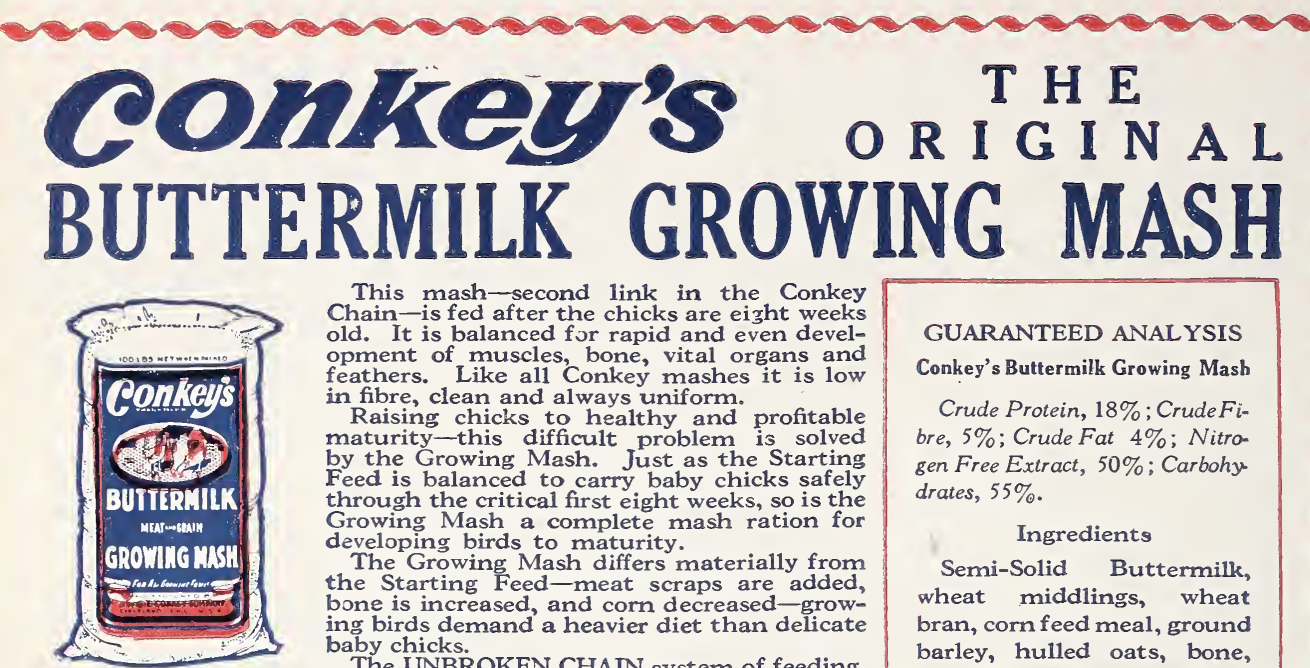

This mash-second link in the Conkey Chain-is fed after the chicks are eight weeks old. It is balanced for rapid and even development of muscles, bone, vital organs and feathers. Like all Conkey mashes it is low in fibre, clean and always uniform.

Raising chicks to healthy and profitable maturity-this difficult problem is solved by the Growing Mash. Just as the Starting Feed is balanced to carry baby chicks safely through the critical first eight weeks, so is the Growing Mash a complete mash ration for developing birds to maturity.

The Growing Mash differs materially from the Starting Feed-meat scraps are added, bone is increased, and corn decreased-growing birds demand a heavier diet than delicate baby chicks.

The UNBROKEN CHAIN system of feeding, originated by Conkey-one mash for starting chicks, one for developint, one for layin - teaches an invaluable lesson in demonstrating the need of three different rations for most economical poultry feeding.

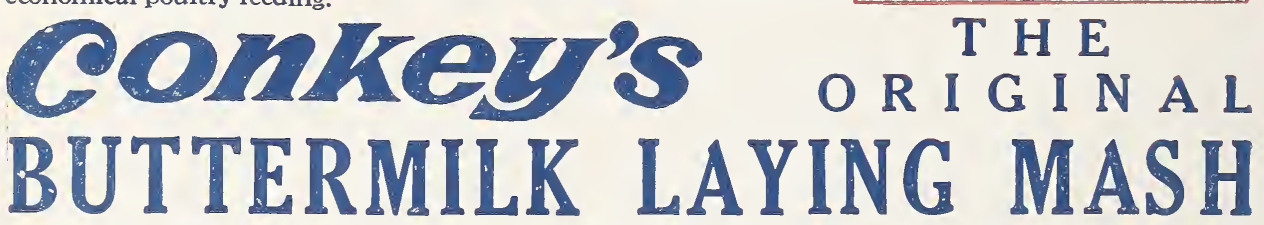

GUARANTEED ANALYSIS

Conkey's Buttermilk Growing Mash

Crude Protein, $18 \%$; Crude Fibre, 5\%; Crude Fat 4\%; Nitrogen Free Extract, $50 \%$; Carbohys drates, $55 \%$.

Ingredients

Semi-Solid Buttermilk, wheat middlings, wheat bran, corn feed meal, ground barley, hulled oats, bone, meat scraps, bean meal and oil meal.

The third link in the Conkey Chain is balanced $f: r$ a full egg basket. Low in fibre, just right in protein for layers.

This mash was placed on the market in response to an insistent demand for an honestly prepared, ers-producing ration that could always be dipended upon to be clean and iniform. This demand arose through loss of egg production which is likely to follow a change of "balance" in feed-too many egg mashes unfortunately are variable in quality and therefore unreliable and costly if $n$ t positively dangerous.

To produce ergs in abundance, the flock muct have a balanced ration consisting of a cry mash and a good scratch grain mixture, also a regular supply cf green stuff. Grains alone are not a sufficient ration for laying hens. Conkey's Buttermilk Laying Mash is 感 made by Conkey's ORIGINAL process. Fresh, Semi-Solid buttermilk
and other ingredients are blended so as to tempt the hen's appetite, thus increasing consumption of dry mash so essential to large egg production.

Insist on Conkey's mashes-you can always depend on them. Conkey feeds are always clean, wholesome and uniform.

\section{Conkeys SCRATCH GRAINS}

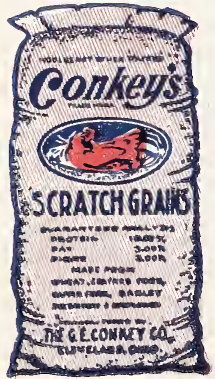

Conkey makes three sizes of Scratch Grains -Conkey's Scratch Grains, for hens; Conkey's Growing Grains, for growing chicks; and Conkey's Chick Grains, for baby chicks.

These mixtures are the connecting links in the complete Conkey Chain. They hook together and re-enforce the three great links when fed with Conkey's Buttermilk Mashes.

Every grain is bright, clean, plump and "meaty" - no dirt at the bottom of the bag, no worm-eaten or shriveled ingredients.

Ask us for Conkey's Complete Feeding Directions. Mailed free if you write direct to THE G. E. CONKEY CO.

Cleveland, $\mathrm{O}$.

GUARANTEED ANALYSIS

Conkey's Scratch Grains

Crude Protein, 9.75\%; Crude Fat, 1.75\%; Crude Fibre, $3.00 \%$.

\section{Ingredients}

Wheat, cracked corn, kaffir corn barley, buck wheat and sunflower seed.

Ask us for analyses of other Conkey grains 


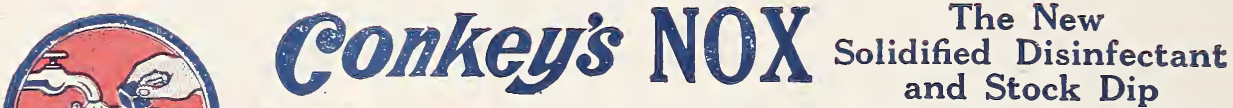

Here at last is a high-grade disinfectant in solid form. A little cube-only an inch square-mixed in water makes a gallon of dip or disinfectant with a co-efficient of 5.25 , making it 2 to 3 times as strong as most coal tardisinfectants.

No fuss and bother with heavy, leaky cans and steel drums. No waste, no guessing as to mixture. A saving on freight and packing charges.

Conkey's Nox is made of imported oils - noted for their uniformity-and concentrated by an exclusive, patented process.

Packages, 6 cubes, 25c; 15 cubes, 60c; 30 cubes, $\$ 1.00 ; 75$ cubes, 21/2 lbs., \$1.75; 150 cubes, 5 lbs., $\$ 3.25$. Ask for prices on lirger aumntitios.

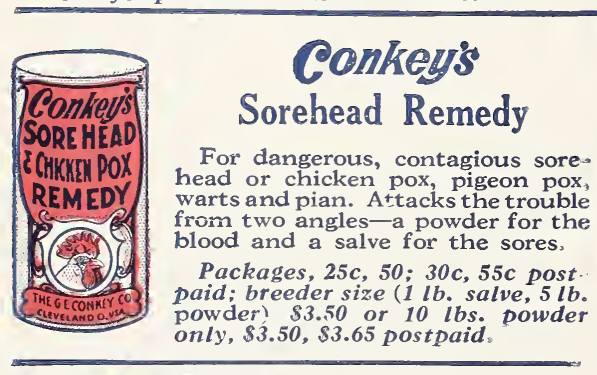

\section{Conkeys' Gape Remedy}

Two different powders-both in same box for one price-one sifted over chicks forces them to cough up parasites, the other is a tonic to put in feed.

Packages, 25c, 50c; 30c, 55c postpaid.

\section{Conkeys Poultry Conditioner}

Highly-concentrated fowl regulator, blood puri fier and nerve food for run-down birds and conlitioning show birds.

Packages, $25 c, 50 c ; 30 c, 55 c$ postpaid.

\section{Conkeys Limberneck Remedy}

For Limberneck, Ptomaine Poisoning, etc.

Packages, 50c; 55c postpaid.

\section{Conkeys's Scaly Leg Remedy}

A few applications does the work.

Package, 25ic Postpaid.

\section{Conkeys's Blackhead Remedy}

Turkey breeders should have a package on hand as blackheadis deadly in advanced stages. Should be given regularly to growing poults. Packages, 50 ; $55 c$ postpaid.

\section{Conkey's Poultry Worm Remedy}

This prescription rids birds of many troublesome worms, thus promoting a return to healthy conditions. Give it as soon as you suspect worms -it will help the whole flock.

Packages, 25c, 50c, 30c, 55c postpaid; breeder gize, (5 lbs.) \$2.75, \$2.85 postpaid.

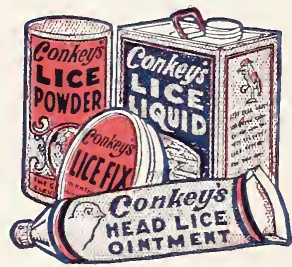

\section{Conkeys's} Lice Powder

For dusting hens, nests, growing chicks -wherever body lice must be overcome.

Packages, 10c, 25c, 50c; pails 12-lb. \$1.40: 25-lb. \$2.75. Parcel post, express or freight, extra.

\section{Conkeys' Lice Liquid}

For painting roosts, fittings, inside of house, nest boxes and wherever mites congregate.

Cans-qt. 60c, 2-qt.90c; gal. $\$ 1.50 ; 5-g a l . \$ 7.00$, parcel post, express or freight extra.

\section{Conkeys' Head Lice Ointment}

For overcoming and preventing murderous head louse which "eats up" baby chicks.

\section{Packages, 10c, 25c, postpaid.}

\section{Conkeys' Conkey's Lice Fix}

A preparation in ointment form for fighting body lice. One application lasts a month. Packages, 25c, 50c postpaid.

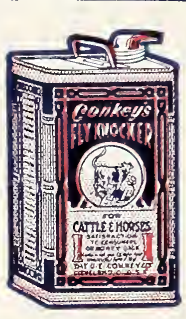

Conkeys'Fly Knocker

\section{Dairymen, horsemen, cattler} men, and sheep raisers declare this remedy the best investment they make-animals free from insects do better in milk and butter fat production, while growing stock unquestionably fattens faster when relieved from disease-spreading insects.

Cans-qt. 60c; $1 / 2$ gal. 90c; gal. $\$ 1.50 ; 5$ gal. $\$ 7.25 ; 10$ gal. \$14.00. Parcel post, express or freight extra.

\section{Conkeys's Stock Tonic}

A general conditioner of real merit for live stock.

Packages, 25c, 50c: pails, 12 lb. \$2.10; 25 lbs. \$3.45: bags, 50 lb. \$5.25; $100 \mathrm{lb}$. \$10.00, Parcel post, express or freight charges extra.

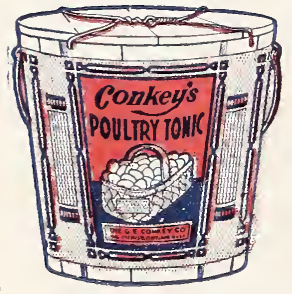

\section{COnkeys POULTRY TONIC}

Every bird from chick to maturity wi:1 be more productive, healthier and more profitable if given a good tonic and rezulator. Conkey's Poultry Tonic helps birds to get more out cf their feed; they produce more eggs and better flesh on LESS FEED, by better digestion and assimilation.

Conkey's Tonic is all medicine-frce from filler, red pepper, and "hot stuff" to overstimulate the birds and break down their health. Conkey's builds on a natural, healthy basis, inducing steady and persistent laying. Keeps the young chicks growing, makes molting easy, strcngthens the bird for bad weather and generally maintains a high health average.

Buy it by the pail. Packages, 25c, 50c, \$1.00; pails, 12-lb. $\$ 1.60 ; 25-l b$. $\$ 3.00 ;$ bags, $50-l b . \$ 5.00 ; 100-l b$. $\$ 9.50$. Parcel post, express or freight charges extra. 


\section{SELECTED FLOWER SEED-Continued.}

\section{Asters}

It is unnecessary to dwell on the great beauty of these popular favorites, as they are appreciated by everyone. Asters are annuals, and they are sufficiently hardy to endure a little frost without injury.

We recomend sowing seed of a number of varieties, as by this method of culture the blooming season can be made to extend from June until late in the autumn.

ASTERS-TALL MIXED-Pkt. 10c; 1/4 oz. 50c. ASTERS, DWARF MIXED-Pkt. $10 \mathrm{c} ; 1 / 4 \mathrm{oz} .50 \mathrm{c}$. GIANT COMET ASTERS, MIXED-Pkt. 10c. PEONY-FLOWERED A T T R S, MIXEDPkt. 10c.

SEMPLES BRANCHING ASTERS:

White-Pkt. $10 \mathrm{c} ; 1 / 4$ oz. $60 \mathrm{c}$.

Light Pink-Pkt. $10 \mathrm{c} ; 1 / 4$ oz. $60 \mathrm{c}$.

Rose-Pkt. $10 \mathrm{c} ; 1 / 4$ oz. $60 \mathrm{c}$.

Lavender-Pkt. $10 \mathrm{c} ; 1 / 4$ oz. $60 \mathrm{c}$.

Purple-Pkt. $10 \mathrm{c} ; 1 / 4$ oz. $60 \mathrm{c}$.

Mixed-Pkt. $10 \mathrm{c}$; oz. $45 \mathrm{c}$.

CREGO ASTERS-One of the finest varieties. Flowers gigantic in size. Has appearance of a chrysanthemum.

Mixed Colors-Pkt. $10 \mathrm{c} ; 1 / 4$ oz. $65 \mathrm{c}$.

BACHELOR'S BUTTON-See Centaurea Cyanus.

BALLOON VINE-10 ft. A rapid-growing annual climber, with white flowers and inflated seed pods which look like small balloons. Succeeds best in warm soil.

Pkt. 10c; oz. 40c.

BALSAM APPLE AND PEAR - Ornamental climbers, with pretty foliage and flowers, followed by handsome fruit, which, when ripe, bursts open, exposing the bright-red seeds within.

BALSAMINA-(Balsam Apple).

Pkt .5c; $1 / 2$ oz. $30 \mathrm{c}$.

CHARANTIA-(Balsam Pear).

Pkt. 5c; $1 / 2$ oz. 25c.

BALSAM-Lady Slipper. Balsams love rich soil, and plenty of water. Sow the seed in window boxes or hot-beds early, or in the open air in May, and transplant when 2 or 3 inches in height. Stimulate by weekly applications of liquid manure. Camelia-flowered.

DOUBLE BALSAM MIXED.

Pkt. $10 \mathrm{c} ; 1 / 2$ oz. 50c.

SCARLET RUNNER, BEAN - An exceedingly rapid grower. Its strong vines are always clothed with deep scarlet flowers from early summer until fall.

Price-Pkt 5c;1/4 tb. 15c; 1/2 lb. 25c.

BRACHXCOME - Swan River Daisy, a very pretty sma!l flower of light blue color.

Pkt. $5 \mathrm{c} ; 1 / 4$ oz. $4.0 \mathrm{c}$.

BEGONIA-Few plants can be grown so readily from seed and afford such brilliancy of flower.

Special Fine Mixed-Pkt. 25c.

BELLIS-English Daisy. Perennials which will stand the winter if given the protection of a few leaves or litter; in bloom from early spring until well on in the summer. Easily raised from seed.

Longfellow-Double pink. Pkt. 10c.

Snowball-Double white. Pkt. 10c.

Double Mixed-All colors. Pkt. $5 \mathrm{c}$.

CALENDULA - (Pot Marigold). $2 \mathrm{ft}$. Calendulas bloom all summer and thrive anywhere, especially in city gardens. The graceful starshaped flowers exhibit every shade of yellow from ivory to deep orange. Well adapted for cutting, being borne upon long stems.

MIXED-All the double sorts.

Pkt .5c; $1 / 2$ oz. $30 \mathrm{c}$.

CALLIOPSIS-Showy, beautiful, free-blooming plants, producing large, bright flowers of rich and charming colors throughout the entire summer.

CALLIOPSIS-Best mixed. Pkt. $5 \mathrm{c} ; 1 / 4$ oz. $25 \mathrm{c}$. CANARY BIRD VINE-Grows to a height of 15 feet. Has beautiful foliage and yellow flowers. Pkt. $5 \mathrm{c} ; 1 / 4$ oz. $30 \mathrm{c} ; 1 / 2$ oz. $50 \mathrm{c}$.

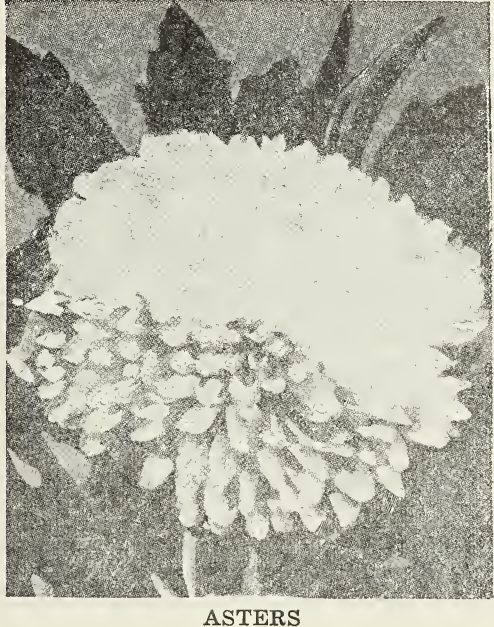

\section{Candytuft}

A dwarf annual of easiest culture; free-blooming, showy, and useful for beds, borders and edgings. Sow seeds where plants are to bloom, in rows 6 or 8 inches apart, thinning out to afford plenty of room, as they branch quite freely. Height, 1 foot.

CRIMSON-Rich, dark crimson. Pkt 5c.

WHITE ROCKET-Long white flower spikes. Pkt. 5c.

EMPRESS-White, large flower. Pkt. 5c.

LITTLE PRINCE-Pure White-Grows 6 inches high. Pkt. $5 \mathrm{c}$

SEMPERVIRENS-White-Survives winter outof- doors. Its fine flowers are produced early in the spring. Pkt. 10c.

UMBELATA-Pretty shade soft lilac. Pkt. 5c.

Annual Sorts-Pkt. $5 \mathrm{c}$.

\section{Cannas}

INDIAN SHOT-These very attractive summer bedding plants can be grown readily from seed. The seed is extremely hard and should be soaked in warm water until swollen. Sow singly in small pots of sandy soil and set in a warm place, preferable a hot-bed or sunny window. Set out in June where they are to flower.

CROZY-Dwarf mixed. Pkt. 5c.

\section{Carnations}

These very popular favorites are valuable for culture in the open ground in summer and for pot culture in winter. Seeds of the Margaret and Chabaud types sown in the spring, will, by August, produce plants that will be full of bloom until frost takes them; or they may be cut back, potted, and carried over winter in a cool room. The Grenadine and Double Mixed bloom the second season after sowing.

MARGARET-Mixed, pkt. 5c.

MARGARET-Scarlet. Pkt. 5c.

MARGARET-Pink. Pkt. 5c.

MARGARET-White; fine double flowers.

Pkt. $10 \mathrm{c}$.

GIANT MARGARET-Immense double flowers.

Pkt. 10c.

FINE DOUBLE MIXED-Many colors. Pkt. 10c。

CASTOR OIL PLANT-(See Ricinus).

CELOSIA-(See Coxcomb). 


\section{SELECTED FLOWER SEED-Continued.}

\section{Cornflower}

CENTAUREA - Sometimes called "Bachelor's Button," and "Ragged Robin." One of the most popular of our garden annuals, blooming continually all summer.

Double Blue-Pkt. $5 \mathrm{c} ; 1 / 4$ oz. $40 \mathrm{c}$.

Double Mixed Colors-Pkt. 5c; $1 / 4$ oz. 25c.

CENTAUREA-The Dusty Miller. The whiteleaved, fine for borders, bedding and hanging baskets. Pkt. $5 \mathrm{c} ; 1 / 2$ oz. $60 \mathrm{c}$

CENTAUREA-Moschata (Sweet Sultan.) Handsome fragrant, purple and white flowers. Pkt. 5c.

CHRYSANTHEMUM - Perennial; all colors, double mixed. Pkt. $5 \mathrm{c} ; 1 / 4$ oz. $25 \mathrm{c} ; 1 / 2$ oz. $45 \mathrm{c}$.

CLEMATIS-Japan's Virgin Bower. Climbing vines of rapid growth. Pkt. 10c.

COBAEA SCANDENS-One of the most rapid growing of the annual climbers. Climbs 20 feet in a season. The flowers are bell-shaped. Plant the seed edgewise and cover lightly. Pkt. 5c ; $1 / 4$ oz. $25 \mathrm{c} ; 1 / 2$ oz. $45 \mathrm{c}$.

COCKSCOMB CELOSIA-Easily grown annuals, fine for summer flower beds, pot plants and for drying for winter bouquets. Sow in light soil, not too rich. Celosia or Plumed Varieties, mixed colors. Pkt. $5 \mathrm{c} ; 1 / 4$ oz. $40 \mathrm{c}$; $1 / 2$ oz. $75 \mathrm{c}$.

COMB VARIETIES, Tall Mixed Colors-Pkt. 5c : $1 / 4$ oz. $35 \mathrm{c}$

Dwarf Mixed Colors-Pkt. 5c; 1/2 oz. 60c.

\section{Dianthus or Garden Pinks}

Annuals and perennials, embracing some of the most popular flowers in cultivation, producing a great variety of brilliant colors, and profusion of bloom. The Chinese and Japanese varieties bloom the first season, same as hardy annuals; height 1 foot. The hardy perennial varieties are very fragrant and of easy culture for the garden or greenhouse.

DOUBLE CHINA PINK-Finest colors mixed Pkt. $5 \mathrm{c} ; 1 / 4$ oz. $25 \mathrm{c}$; $1 / 2$ oz. $45 \mathrm{c}$.

DOUBLE JAPAN PINK-Flowers large, brightest colors mixed. Pkt. $5 \mathrm{c} ; 1 / 4$ oz. $30 \mathrm{c}$.

SINGLE ANNUAL MIXED-Pkt. $5 \mathrm{c} ; 1 / 4$ oz. $20 \mathrm{c}$.

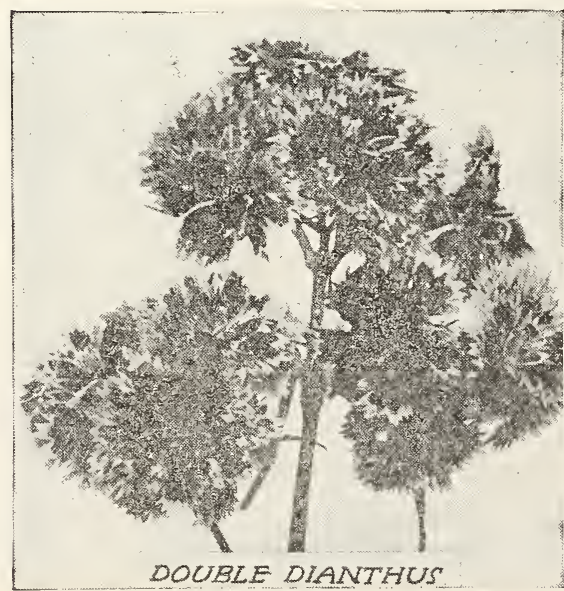

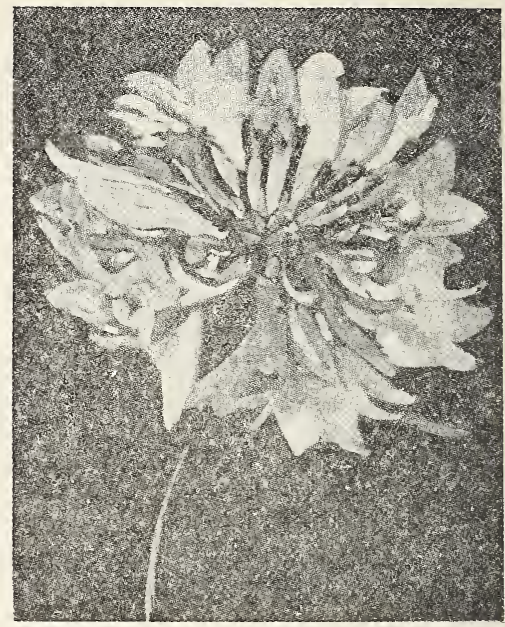

CENTAUREA (CYANUS-CORNFLOWER)

\section{Cosmos}

A hardy annual having strong stems from 4 to 6 feet high with delicate, feathery foliage and pretty flowers of shades of rose, red, pink, yellow, and also pure white. One of the most popular fall flowers; excellent for cutting. Cosmos is most effective when planted in broad masses or along background borders against fences or evergreens. Cosmos may be had in bloom from August until frost.

Topping the plants when 1 foot high will induce early blooms.

LADY LENOX GIANT COSMOS-Flowers 5 to 6 inches in diameter. Color a beautiful shell pink. Pkt. $10 \mathrm{c} ; 1 / 2$ oz. $25 \mathrm{c}$

GIANT FLOWERED, S U P E R B M I X E D COSMOS-Pkt. $10 \mathrm{c} ; 1 / 2$ oz. $40 \mathrm{c}$

WILD CUCUMBER VINE - Rapid climbers, growing 30 feet a season. Fragrant, pretty white flowers, followed by ornamental, prickly seed-pods. Pkt. $5 \mathrm{c}$; oz. $15 \mathrm{c}$.

CYPRESS VINE-A splendid climber, with delicate dark green, feathery foliage and an abundance of bright star-shaped white and scarlet blossoms. Sow thickly after the middle of April.

Height 15 feet.

White-Pkt. $5 \mathrm{c} ; 1 / 4$ oz. $25 \mathrm{c} ; 1 / 2$ oz. $45 \mathrm{c}$.

Scarlet-Pkt. $5 \mathrm{c} ; 1 / 4$ oz. $20 \mathrm{c} ; 1 / 2$ oz. $35 \mathrm{c}$

Mixed colors-Pkt. $5 \mathrm{c} ; 1 / 4$ oz. $20 \mathrm{c} ; 1 / 2$ oz. $30 \mathrm{c}$.

\section{Dahlia}

Well-known fall blooming plants. They grow very readily from seed which, if sown early, will bloom the same year. Almost any soil suits them, a moist one being preferable. H. H. P. 3 to $5 \mathrm{ft}$. CACTUS FLOWERED-Double Pkt. 10c. DOUBLE, LARGE-FLOWERED-Pkt. 10c. SINGLE MIXED-From fine varieties. Pkt. 5c.

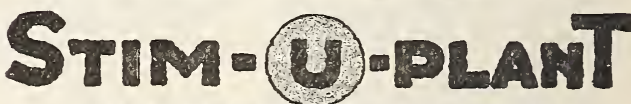

\section{PLANT STIMULANT TABLET}

Trade Mark Registered U.S. Patent Office Small Size, 15c; Large size, 25c.

The best and most economical fertilizer for both indoor and outdoor use. It will keep your ferns and other plants healthy and keep them growing. If you wish to use in liquid form, four tablets will make one gallon. 


\section{SELECTED FLOWER SEED-Continued.}

\section{Digitalis}

FOXQLOVE - Handsome, stately plants, with ornamental green leaves and peridulous flowers, white, pink, blue, purple, etc., beautifully spotted. H. P. Height 2 feet. Mixed colors. Pkt. 5c ; $1 / 4$ oz. $30 \mathrm{c} ; 1 / 2$ oz. $50 \mathrm{c}$.

DOLICHOS (Hyacinth Bean)-Rapid climbers, bearing large clusters of purple and white flower followed by ornamental plants. Pkt. $5 \mathrm{c}$; oz. $25 \mathrm{c}$.

ESCHSCHOLTZIA (California Poppy)-All colors mixed. Pkt. 5c; $1 / 4$ oz. $20 \mathrm{c} ; 1 / 2$ oz. $35 \mathrm{c}$.

FEVERFEW-Double pure white flowers.

Pkt. $5 \mathrm{c} ; 1 / 4$ oz. $20 \mathrm{c} ; 1 / 2$ oz. $35 \mathrm{c}$.

FORGET-ME-NOT (Myosotis).

Alpestris-Dark blue; in bloom all summer

Pkt. $5 \mathrm{c} ; 1 / 4$ oz. $40 \mathrm{c}$.

Mixed Colors-Pkt. 5c.

GAILLARDIA (Blanket Flower)-Perennial Hybrid Mixed Colors. Pkt. $5 \mathrm{c}$; $1 / 4$ oz. $40 \mathrm{c} ; 1 / 2$ oz. $75 \mathrm{c}$.

GLOBE AMARANTH-Red clover-shaped flowers. Cut when in bloom and dried, they retain their colors.

Mixed Colors-Pkt. 5c.

GODETIA-Satin Flower. Mixed Colors. Pkt. 5c. GOURDS-Ornamental. See page 29.

GYPSOPHILA-Baby's Breath. Pure white, tiny flowers. Pkt. 5c.

HELIOTROPE-Fine mixed colors. Pkt. 5c.

H O L L Y H O C K-Double. All colors mixed. Pkt. 5c.

KENILWORTH IVY - Tender perennial, of trailing habit, bearing small violet flowers. Fine for boxes, rockeries, and hanging baskets. Pkt. $5 \mathrm{c}$.

KOCHIA, or Burning Bush; Summer Cypress, or Mexican Firebush-2 to 3 feet. Makes a pyramidal-shaped cypress-like bush with feathery, light green foliage, deepening until it becomes a lovely crimson. Pkt. $10 \mathrm{c} ; 1 / 2$ oz. $25 \mathrm{c}$.

LARKSPUR-Very popular annual plants of the easiest culture. Beautiful, graceful flowers of many colors are borne on long spikes; fine for cutting; height 1 foot. Pkt. 5c.

MARVEL OF PERU (Four o'clock) - Blooms first season. Height 2 feet. Flowers showy, open only in the afternoon. Pkt. 5c.

NIGELLA (Love in a Mist, or Devil in a Bush)-Bright, showy flowers, requiring but little care. Height 1 foot. Mixed colors. Pkt. 5c.

MOONFLOWER - (Evening Glory Ipomoea)-Hardy annual. one of the most rapid climbers: grows 50 to 75 feet. Vines robust and covered with large white flowers, opening in the evening, and remaining open until about noon of the next day. Pkt. $10 \mathrm{c}$; oz. $60 \mathrm{c}$.

LOBELIA-Easy to grow; one of the best plants for rockeries, pots and bedding; a mass of blooms for a long season.

Pkt. 5c.

MIGNONETTE - (Sweet)Very fragrant. Bears large spikes of flowers. Pkt. 5c.

\section{Japanese Morning Glories}

These beautifully marked and most daintily tinted flowers are one of the grandest climbers. Grows 30 to 50 feet. Flowers measure 4 to 6 ins. across; foliage very ornamental. Pkt. 10c.
FANCY FRINGED - A new imported variety from Japan. Flowers very large, ruffled from stem to margin like crumpled velvet. Pkt. $10 \mathrm{c}$.

FINE MIXED-Mixture of all best varieties Pkt. $5 \mathrm{c} ;$ oz. $15 \mathrm{c} ; 1 / 4$ tb. $35 \mathrm{c}$.

\section{Select Nasturtiums}

We are importers of the choicest strains of both the Dwarf or "Tom Thumb" and Tall or Running varieties of Nasturtiums.

NASTURTIUMS are one of the hardiest and most attractive summer blooming plants; will begin blooming early in the spring and continue until killed by frost. They will bloom best in thin, well-drained soil. No other annual will produce blooms in such profusion; they are unexcelled for their brilliancy and variety of colors.

\section{Dwarf Nasturtiums}

VARIEGATED LEAVES-Very beautiful, even when not in bloom; flowers of many colors show to great advantage among the variegated foliage.

QUEEN OF TOM THUMBS-Pkt. 10c; oz. 25c.

IVY LEAVED-Both the flowers and leaves are different from all other sorts. The leaves are a deep green, veined with silvery white. Flowers are star-shaped, rich in colors. Pkt. $10 \mathrm{c}$ : oz. $20 \mathrm{c}$.

DWARF VARIETIES MIXED-Pkt. $5 \mathrm{c}$; oz. $15 \mathrm{c}$; $1 / 4$ tb. $40 \mathrm{c}$; tb. $\$ 1.50$ (by mail postpaid,

ib. $\$ 1.60$.)

\section{Tall or Running Nasturtiums}

VARIEGATED LEAVED - Similar to Dwarf varieties, except in habit of growth, being tall. Pkt. $5 \mathrm{c} ;$ oz. $15 \mathrm{c} ; 1 / 4$ tb. $50 \mathrm{c}$.

IVY LEAVED-Similar to Dwarf varieties, except in habit of growing, being tall. Pkt. 5c; oz. $15 \mathrm{c} ; 1 / 4$ tb. $40 \mathrm{c}$; tb. $\$ 1.50$ (by mail postpaid. ib. $\$ 1.60)$.

TALL VARIETIES MIXED-Pkt. $5 \mathrm{c}$; oz. 15c : $1 / 4$ tb. $40 \mathrm{c}$; tb. $\$ 1.50$ (by mail postpaid, tb. $\$ 1.60$ )

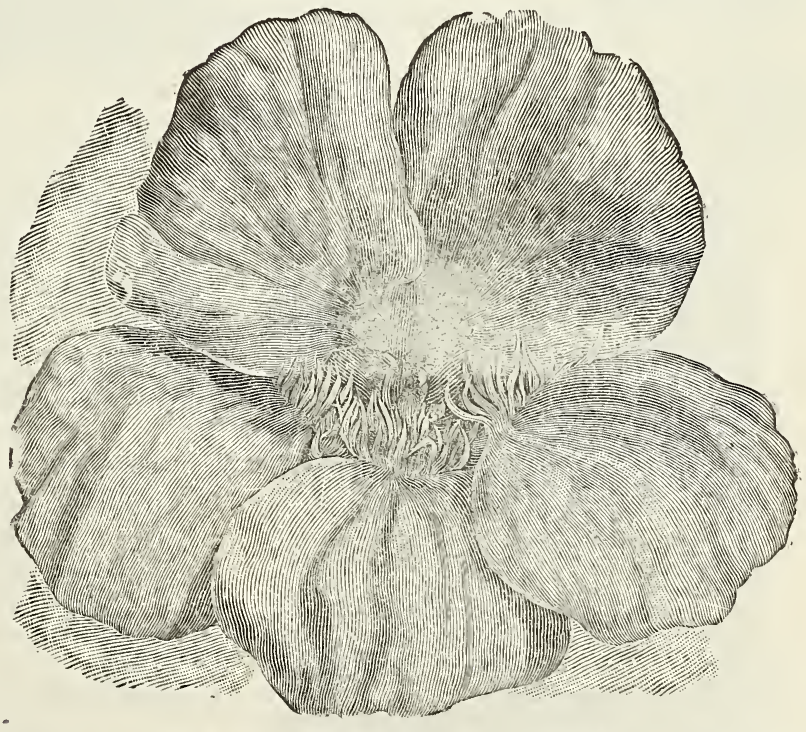

\section{SELECT TALL MIXED NASTURTIUM}

FLOWER PLANTS-See pages 30 and 31 . We offer the finest potted stocks for outdoor bedding or potting in season. 


\section{SELECTED FLOWER SEED-Continued.} Giant Pansies

Pansy Seed should be sown in well pulverized soil, and covered not more than a quarter of an inch. Sowing in February or March should be made in boxes covered with glass. Transplant to a partially shady place in a rich, moist soil.

GIANT FLOWERED PANSY MIXTURE-This is a mixture of the finest strains of Giant Pansies, seeds coming from the world's famous pansy growers, whose flowers are of the richest colors and largest size. Each flower is a gem of velvet and goid, blotched and mottled of many tints. Pkt. 10c; 3 pkts. 25c; $1 / 4$ oz. $\$ 3.00$.

CHOICE MIXED PANSIES-A choice mixture of all colors, shades and markings. Pkt. 5c; 6 pkts. $25 \mathrm{c} ; 1 / 4$ oz. $\$ 1.00$.

\section{Petunia}

The ease of culture, and duration of bloom, will make Petunias always very popular. The large flowers borne profusely.

BURPEE'S DEFIANCE FRINGED PETUNIAS - This strain is without an equal for its beautifully fringed or ruffled flowers, at their edge often measuring 4 to 6 inches across. Pkt. 25c.

DOUBLE MIXED PETUNIAS-These beautiful marked Petunias produce a large percentage of double flowers of the largest and brightest colored fringed varieties. Pkt. $15 \mathrm{c} ; 2$ for $25 \mathrm{c}$.

SINGLE MIXED PETUNIAS-A fine mixture of all colors. Pkt. 10c; $1 / 4$ oz. 60c.

\section{Poppies}

These most beautiful hardy annuals and perennials are of easy and quick growth. Their gorgeous flowers are borne throughout the summer.

ORIENTAL-Perennial; bears huge flowers of the most delicate and dazzling colors, and they increase in size and beauty each season. Pkt. 10c ; $1 / 8$ oz. $40 \mathrm{c}$

I C E L A N D-Perennial ; blooms continuously from June to October. They resemble crushed satin. Pkt. 5c; $1 / 8$ oz. 25c.

SHIRLEY-Annuals. Brilliant and free flowering. Pkt. $5 \mathrm{c} ; 1 / 8$ oz. $15 \mathrm{c}$.

DOUBLE PEONY FLOWERED ANNUALSLarge flowers resembling Peonies. Mixed Colors. Pkt. 5c; oz. $35 \mathrm{c}$.

SINGLE MIXED-Annuals. Contains the best strains of single poppies, mixed colors. Pkt. $5 \mathrm{c}$; $1 / 4$ oz. $40 \mathrm{c}$.

M A R I G O L D-Extremely effective annuals, easily grown and free flowering, bearing early many brilliant flowers, continuing until killed by frost.

Double French Mixed-Pkt. 5c; oz. $75 \mathrm{c}$.

African Double Mixed-Pkt. $5 \mathrm{c}$; oz. $75 \mathrm{c}$.

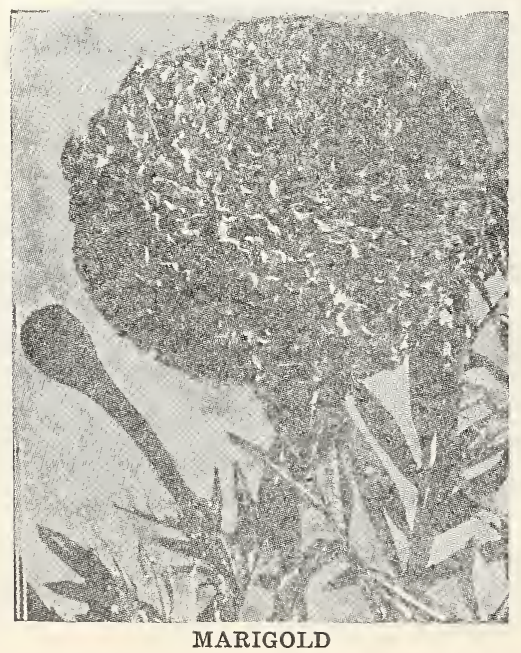

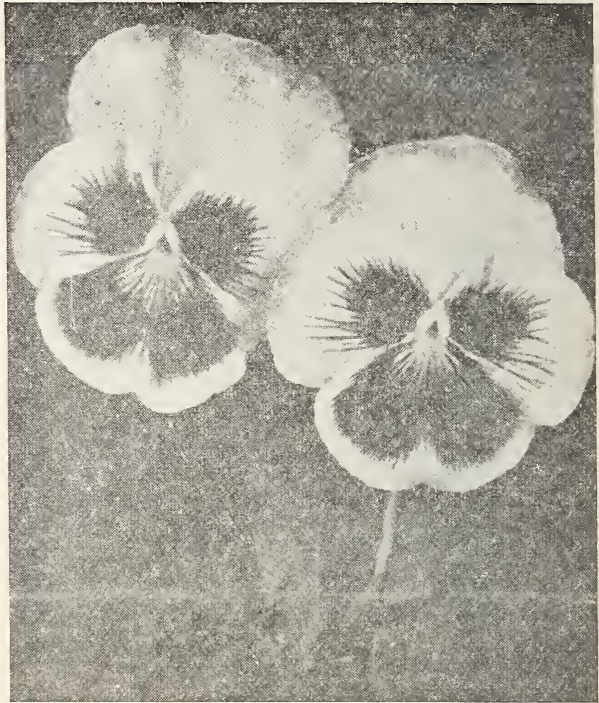

Giant Flowered Pansies

Phlox

Few flowers can equal these beautiful annuals in their magnificent display of their many and brilliantly colored flowers.

PHLOX DRUMMONDI GRANDIFLORA-Th is superb strain is noted for larger flowers and rich colors. Pkt. 10c; 1/8 oz. 25c.

STAR AND FRINGED-Very beautiful, and of the most varied colors. These star-shaped varieties are bordered with white. Pkt. 10c.

FINE MIXED-A mixture of all the choicest colors. Pkt. 5c; $1 / 4$ oz. $40 \mathrm{c}$.

\section{Portulaca}

(Miss Flower)-Will succeed in any sunny location, producing great profusion of flowers of almost every color.

SINGLE MIXED COLORS-Pkt. $5 \mathrm{c} ; 1 / 2 \mathrm{oz} .45 \mathrm{c}$.

DOUBLE MIXED COLORS-Pkt.10c; $1 / 02.75 \mathrm{c}$.

RICINUS (Castor Bean) - These are fine for backgrounds or center of beds. Tall plants with palm-like leaves.

All the best varieties of colored leaves.

Pkt. $5 \mathrm{c} ;$ oz. $20 \mathrm{c} ; 1 / 4$ ib. $65 \mathrm{c}$

\section{Salvia-Flowering Sage}

A hedge or bed of Salvias is a blaze of color during the summer and fall. They are used to good effect for bordering Canna beds, also for hedges along walks or lot dividing lines. Seed should be started either indoors or in a hot-bed; do not sow in open ground until soil has become well warmed.

SALVIA SPLENDENS-21/2 $\mathrm{ft}$. The well-known variety; very fiery scarlet. Pkt. $10 \mathrm{c} ; 1 / 8$ oz. $35 \mathrm{c}$.

\section{Sunflower}

MINIATURE VARIETIES MIXED - Pkt. 5c ; oz. 50 .

DOUBLE CALIFORNIA-Double yellow variety, 3 to 5 feet high. The giant flowered. Pkt. $10 \mathrm{c}$; oz. 50 .

DOÜBLE CHRYSANTHEMUM FLOWEREDThe grandest of all double Sunflowers. Pkt. 10c ; oz. 50.

MAMMOTH RUSSIAN - The giant flowered sunflower, 5 to 8 feet high. Pkt. $5 \mathrm{c} ; 1 / 4$ 1b. 10c; 1b. $35 \mathrm{c}$.

NEW RED-Very attractive. Pkt. 10c; oz. 75c.

\section{Stocks, Gilliflower}

Very useful annuals for borders, bedding and cut fiowers. Blooms are very fragrant.

TEN WEEKS - Cut and Come Again - Mixed colors. Pkt. $10 \mathrm{c} ; 1 / 4$ oz. $25 \mathrm{c}$. 


\section{SELECTED FLOWER SEED-Continued.}

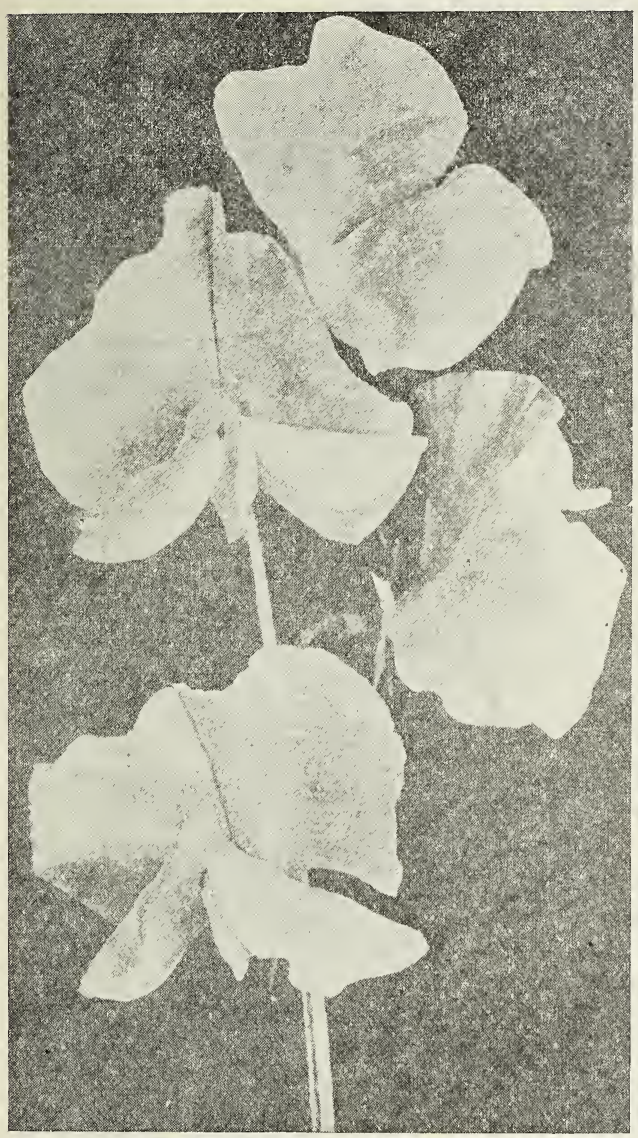

\section{SUPERB SPENCER SWEET PEAS}

\section{Sweet Peas}

No flower has ever gained the popularity in so short a time as the Sweet Pea. Its development in the South has been much slower than other sections, but it is now very firmly established, and gaining rapidly from year to year. The great drawback to its advancement in the South has been through an improper knowledge of the habits of the Sweet Pea. It is necessary for success with this flower to carefully observe tried methods of culture.

Culture for Sweet Peas-October to April have been found the best months to plant Sweet Peas in this section. ONE OUNCE SOWS 25 FEET OF ROW: 1 POUND WILL PLANT ABOUT 400 FEET IN DRILLS. Would suggest that you have your rows or drills if possible running north and south. Plant in double rows 8 inches apart, $21 / 2$ feet between the double rows; poles then could be placed between the double rows and wires run or poultry netting placed; this would give support for two rows on trellis. If poultry netting is used, use 4 to $5 \mathrm{ft}$. 2-in. mesh.

Dig rows 10 inches deep, put in 4 inches of well rotted manure or prepared pulverized sheep manure and top soil well mixed. Plant seed on this and cover with loose black loam 2 inches deep, leaving the rows open, and fill in as the peas crack through until you get to the surface of soil.

During dry weather they sould be watered thoroughly and frequently, and given an application of liquid manure once a week. When in bloom flowers should be cut every day and put in water. This will prevent the plants from go- ing to seed, which would stop them from continuing in bloom.

SUPERB SPENCER SWEET PEAS-A strain of Sweet Peas developed from the old Grandiflora type. It is sometimes known as the Orchid Flowering Sweet Pea, and produces larger and more fragrant flowers of greater brilliancy of color than the old type. The long graceful stems usually bear 4 to 5 blossoms of superior beauty. We offer the following fancy Named Varieties of the Spencer type and consider them unsurpassed in both richness of color and beauty of form.

Asta Ohn-Pinkish lavender; extra large flower.

Othello-Rich maroon; the best of dark colored spencers.

Countess Spencer-Beautiful soft pink color; a most popular variety.

George Herbert-Bright rose-carmine.

Helen Lewis-A fine orange rose variety.

King Edward-Rich crimson-scarlet; large wavy flower.

King White-Considered by all the finest white variety.

Price, postpaid, all varieties listed above.

Pkt. 10c; oz. 45c; 1/4 to. $\$ 1.50 ;$ 1b. $\$ 4.00$.

SUPERB SPENCER MIXED SWEET PEASThis is a superior mixture of all colors.

Postpaid-Pkt. 10c; oz, 35c; 1/ to $\$ 1.00 ; 1 \mathrm{~b} . \$ 3$.

GRANDIFLORA SWEET PEAS MIXED-Postpaid-Pkt. 5c; oz. $25 \mathrm{c} ; 1 / 4$ to. $70 \mathrm{c} ; 1 \mathrm{~b} . \$ 1.75$.

\section{Sweet William}

SINGLE-Many bright co'ors mixed. Pkt. 5c; $1 / 4$ oz. $30 \mathrm{c} ; 1 / 2$ oz. $50 \mathrm{c}$.

DOUBLE-All colors mixed. Pkt. $5 \mathrm{c} ; 1 / 4$ oz. $40 \mathrm{c}$. Thunbergia, Black Eyed Susan

Useful for window boxes, hanging baskets, vases, etc. Trumpet-shaped flowers in great profusion in summer.

THUNBERGIA-Mixed colors. Pkt. 5c; 1/4 oz. 40 c.

\section{Verbena}

Popular annuals for beds; also covering mounds. MIXED VERBENAS-All colors.

Pkt. $5 \mathrm{c} ; 1 / 4$ oz. $75 \mathrm{c} ;$ oz. $\$ 2.50$.

\section{Wall Flower}

A favorite garden flower, producing large spikes of deliciously fragrant blooms of many colors.

Double-Large and fragrant. Pkt. 10c; 1/4 oz. $\$ 2$.

\section{Zinnia}

Easily grown, supplying abundantly gorgeous flowers of almost every shade of color during the summer and fall.

DOUBLE FINE MIXED—Pkt. 5c; $1 / 2$ oz. $75 \mathrm{c}$.

POMPON, MIXED-Pkt. 10c.

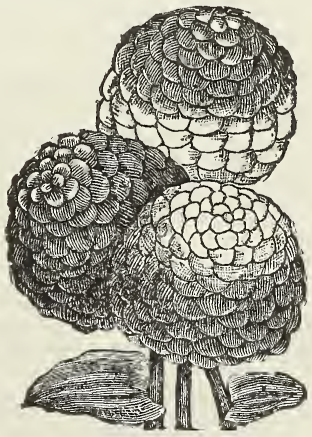

ZINNIA

PAPER FLOWER POTS

For transplanting and shipping potted plants. Write for prices. 


\section{Sow "Cherokee Brand" Field Seeds}

When you purchase "CHEROKEE BRAND" seed you purchase the very highest quality seed that money can buy; and you can rest assured that you are not sowing weeds and paying for chaff. This seed is all thoroughly recleaned and tested for purity and germination. The new "North Carolina Seed Law" requires each merchant to place a tag on all seeds showing purity and germination. We are glad of this law, as it is a protection to the merchants handling high grade seed. "CHEROKEE BRAND" is the best. Before purchasing seeds be sure that they fill the State requirernents. We will be glad to mail you copy of Seed Law on request; and also samples of any seeds you may desire. The large quantities in which we handle field seeds enables us to quote you exceedingly low prices, quality considered. The prices quoted herein are those prevailing during December. Write before ordering for our latest price list.

\section{High Grade Clover and Alfalfa Seed}

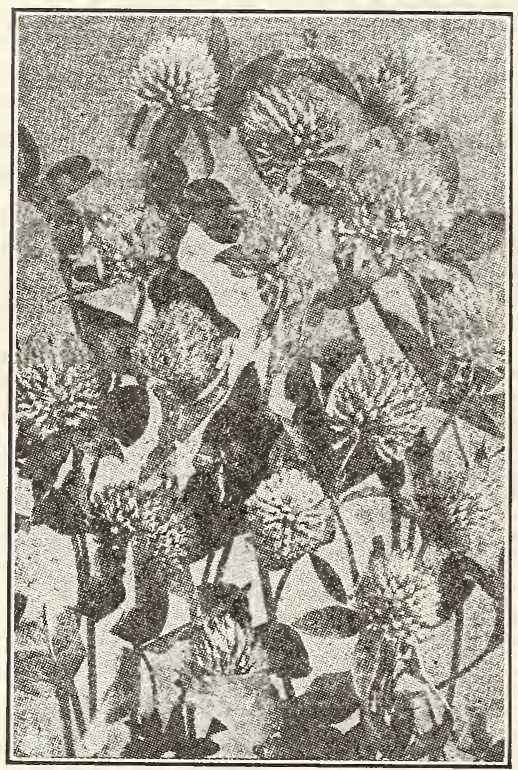

Red Clover

"CHEROKEE BRAND" Clover Seed represents the finest qualities that can be had, expertly recleaned and tested for high purity and strong germination; this brand will always measure up to a superior standard of quality. The so-called "competitive grades" of clovers containing buckhorn, wild carrot, plantain, etc., are lower in price. We do not handle these types.

\section{Red Clover}

This valuable crop is not only one of the most excellent Hay and Forage Crops, but it is a great soil improver. Red Clover can be cut two or three years from one seeding, and on good land will yield two cuttings per year. Red Clover has been found particularly adapted to the northern part of the Cotton Belt; when sown alone in this section, 10 to 12 Ibs. to an acre. Excellent results are received by sowing for hay, a mixture of one bushel of Orchard Grass, one bushel Tall Meadow Oat Grass with eight pounds of Red Clover to an acre. If to be used also for pasture, an addition of six pounds Red Top or Herds Grass to the above mixture will increase the pasturage.

Postpaid-Lb. 35c; 10 lbs. $\$ 3.00 ; 30$ tbs. $\$ 8.50$.

Express-Lb. $30 \mathrm{c} ; 10$ tbs. $\$ 2.75$; bushel about $\$ 16.00$.

\section{Mammoth or Sapling Clover}

This is similar to Red Clover, both in appearance of the seed and its habits of growth, the difference being that it usually grows larger and is later in maturing. It is considered superior as an improver on account of the extra growth. It is a good variety for thin soils, or to seed with Timothy, Meadow Fescue, Herds Grass, or Red Top, as it matures about the same time as these grasses. Sow 10 to $12 \mathrm{lbs}$, per acre by itself or with Timothy. Six 1bs. of Clover and 8 ibs. of Timothy will give a liberal seeding.

Postpaid-Lb. 40c; 10 ibs. $\$ 3.25 ; 30$ Ibs. $\$ 9.00$.

Express-Lb. 35c; 10 tbs. $\$ 3.00$; bushel about $\$ 17.00$.

\section{Alsike Clover}

Sixty pounds to the bushel. A valuable perennial clover, growth of fine texture, more spreading and recumbent than red clover, matures later, has pinkish blossoms and does not make such large roots, nor do they penetrate so deep into the soil. Notwithstanding, it seems to be hardier than red clover, standing as much heat and decidedly more cold. Alsike Clover should be sown in the South from August to March, the sooner the better. It seems to be well adapted to creek and river bottoms. From 8 to 10 ibs. should give a good stand.

Postpaid-Lb. 35c; 10 tbs. $\$ 3.00 ; 30$ Ibs. $\$ 8.00$. - Express-Lb. $30 \mathrm{c} ; 10$ tbs. $\$ 2.75$; bushel, $\$ 15.00$.

\section{Alfalfa or Lucerne}

The Profitable and Nutritious Hay Crop

ALFALFA or LUCERNE in the South will produce from 5 to 7 tons of hay an acre each year. It enriches the soil. Its very large, branching roots penetrate far down, loosening the soil, getting plant food where other crops would be a failure. Alfalfa is a perennial, and lasts for 8 to 10 years. Sow seeds in thoroughly prepared soil at the rate of $20 \mathrm{lbs}$. to the acre. Before sowing the seed it will be best to inoculate them, if alfalfa has never been grown on the soil you are to sow.

The old belief that Alfalfa cannot be grown in this section is gradually being overcome. We know of a great many fields that are yielding three cuttings of most nutritious feed every year. The success of this feed depends largely upon the kind of seed you plant and the correct and thorough preparation of the soil. Seed produced in irrigated fields and imported Alfalfa will not give best results. We offer a type of Alfalfa seed that we know has produced well in Western North Carolina. Use lime liberally, at least a ton to the acre, many use $2 \frac{1}{2}$ tons to the acre.

Postpaid-Lb. 35c; 10 tbs. $\$ 3.00 ; 30$ tbs. $\$ 7.50$.

Express-Lb. 25c; 10 Ibs. $\$ 2.35$; bushel, $\$ 13.50$.

\section{Japan Clover or Lespedeza}

It is known as "poor land alfalfa." A few pounds added to other clover mixtures bring remarkable returns, since this variety of clover is extremely hardy and capable of withstanding the severest colds or droughts. Both the hay and grazing of first nutrition.

Postpaid-Lb. 30c; 10 ibs. $\$ 2.75$.

Express-Lb. 25c; bushel (251bs.) $\$ 6.00$.

\section{White Clover}

Does well in nearly all parts of the South. In this section it is indigenous to all kinds of soils. Is especially valuable and largely used in LAWN and PASTURE MIXTURES. It makes a small, close, compact growth. If sown alone, sow 6 to 8 1bs. an acre; more largely sown with other grasses -in this case use half the amount.

Postpaid-Lb, 75c; 10 tbs. $\$ 7.00$.

Express-Lb. $65 \mathrm{c}$; bushel, $\$ 36.00$.

INOCULATE THIS SEED WITH

FARMOGERM
INOCULATE THIS

SEED WITH

FARMOGERM 
HIGH GRADE CLOVER AND ALFALFA SEEDContinued.

\section{Sweet Clover or Melilotus}

For Forage and Soil Improvement

SWEET CLOVER-Is also known as Bokhara Clover the White Blooming or Melilotus Alba is the most popular sweet clover. It produces a larger growth and is of a superior quality to the yellow, which is very coarse. One of the great uses Melilotus has been put to is to inoculate the soil where alfalfa is intended to be grown, as it contains the same class of bacteria that infest the roots of alfalfa, for it will grow where alfalfa will not the first year. It enriches poor, thin land; prevents land from washing, stands heat and drought remarkably well; is very fattening for all live stock; valuable for bee pasture. It is sown at the rate of 10 to $15 \mathrm{lbs}$. to an acre.

One grower advises that he has used Sweet Clover with wonderful success to prevent washing of mountain lands. He states that he planted a large quantity in old ditches and the result was remarkable. We cannot recommend Sweet Clover too highly as a crop to improve worn-out fields, to inoculate soil for Alfalfa, and as a pasture for hogs and cattle.

Postpaid-Lb. 25c; 10 lbs. $\$ 2.15$

Express-Lb. $20 \mathrm{c} ; 10$ 1bs. $\$ 1.85 ; 100$ tbs. $\$ 15.00$

Inoculate this seed with Farmogerm or Mulford Culture. Seed page 49 .

\section{Bur Clover}

Can only be sown in the summer and fall. For the South it is a most valuable winter grazing crop, growing luxuriantly all through the winter and until the summer comes fully on. It is admirably adapted for use with Bermuda Grass; the combination of the two makes a splendid all-the-year-round pasturage.

Postpaid-Lb. 30c; 10 tbs. $\$ 2.50$.

Express-Lb. 25c; 100 Ibs. $\$ 20.00$.

\section{Crimson Clover}

Best Only for Late Summer and Fall Sowing This variety should be more largely used by

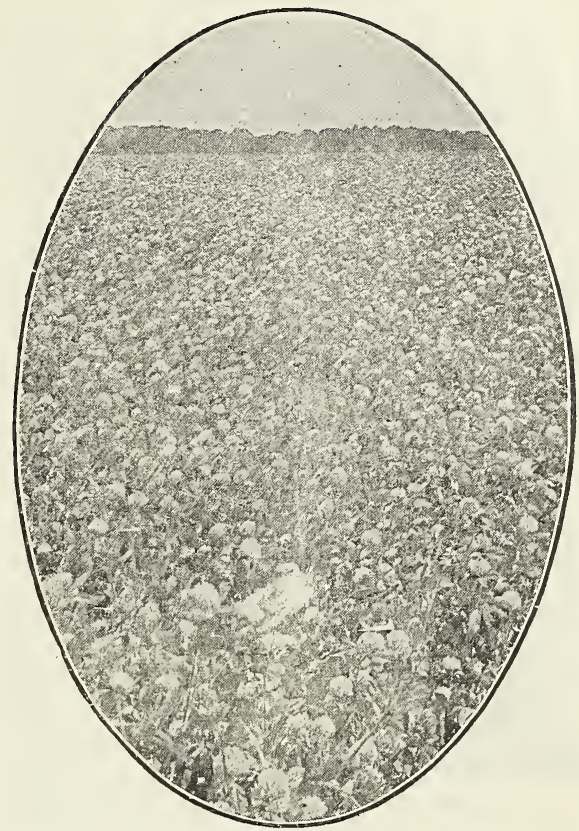

REAL CLOVER-INOCULATION GREW IT

every Southern farmer. Produces an excellent hay and fine winter pasturage. Crimson Clover is one of the finest of all soil-improving crops. Sow at the rate of $15 \mathrm{lbs}$, to an acre broadcast from July to October.

The price of Crimson Clover the past season was very high and we are unable to judge what the price will be the coming season. We will be glad to quote on application in any quantity. Write for Prices.

\section{INOCULATE THIS SEED WITH FARMOGERM}

\section{INOCULATE THIS SEED WITH FARMOGERM}

INOCULATE THIS

SEED WITH FARMOGERM

\section{Our High Quality Grass Seed}

\section{Timothy}

The most important timothy ranks unsurpassed as the hay producer of America. All livestock, especially horses, relish and thrive on it. Timothy prefers good stiff loamy soils containing an abundance of moisture, and is peculiarly adapted for the heavy clay soils of mountainous districts. It is a rapid grower, producing the best crop the first year. However, by manuring or top-dressing with our special gxass fertilizer the succeedms years may bring equally as good yields of this wonderful hay crop. Since it matures with Sapling Clover, Red Top, and Meadow Fescue, any or all of these are valuable additions both in production of larger yields of hay or grazing. If sown with Sapling Clover the clover will help to supply nitrogen. $10 \mathrm{lbs}$. Timothy, $8 \mathrm{lbs}$. Sapling Clover to the acre. Alone use one peck to the acre.

CHEROKEE TIMOTHY - 991/2\% Pure; $95 \%$ Germination.

Postpaid-Lb. $15 \mathrm{c}$; peck $\$ 1.25$.

Express-Peck $\$ 1.10$; bushel $\$ 4.00$.

\section{Kentucky Blue Grass}

This true perennial combines more true points of excellence than any other grass. It is the most widely distributed of all native grasses. The densely creeping root stock, spreading habit and smooth even growth of fine texture and richest green color render Kentucky Blue Grass highly suitable for producing the rich velvety green turf so envied in all good lawns. It forms an early close turf in almost any soil, dry, rocky, sandy or gravelly, and withstands dry weather admirably. It takes several years to establish a heavy sod, and should, therefore, be sown with other grasses. Soils of Western North Carolina should be heavily limed before sowing lawns of Blue Grass. It is also most valuable for pastures because of its productiveness and the wonderful nourishing qualities of the green food. Sow 40 tbs. per acre for lawns and at the rate of 28 ibs. in mixtures for pastures.

Postpaid-Lb. 50c; 10 Ibs. $\$ 4.50$.

Express-Bushel (14 ibs.) $\$ 5.00 ; 50$ tbs. $\$ 17.00$; 100 tbs. $\$ 32.50$. 


\section{Orchard Grass}

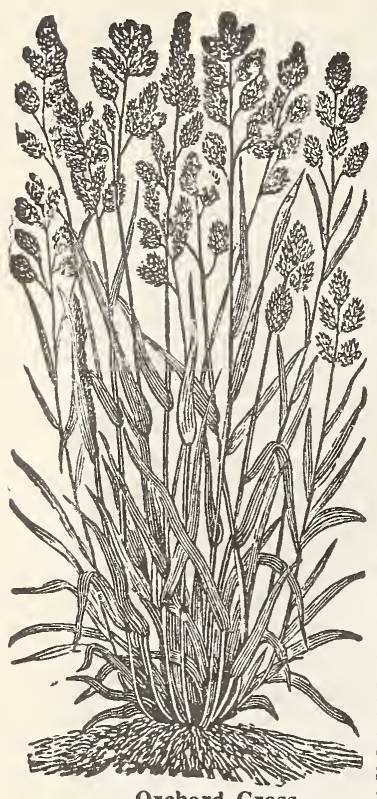

Orchard Grass is probably the best known and most universally used of all varieties of grass. It is very hardy and succeeds anywhere in the United States, yielding enormous crops of most nutritious hay for grazing. All livestock are very fond of it, green or dry, and it endures constant cropping better than any other grass. It $h$ a s been found that Orchard Grass is peculiarly adapted for growing in the shade, and that while it succeeds well on soils of sandy textures, the ideal soils are clay uplands or stiff soils. For finest quality hay it should be cut just before blossoming when the stem is less hard and the pith of the stem is still soft and sweet. After being mown Orchard Grass grows up quickly and yields a heavier aftermath $t h$ a $n$ any other variety of grass. Since this variety grows in tufts, to obtain best results Red

Clover or Tall Meadow Oat Grass, both of which mature at the same time, should be sown with Orchard Grass. The usual rate of seeding of such a mixture is $6 \mathrm{lbs}$. Red Clover, $14 \mathrm{lbs}$. Orchard Grass, and 11 tbs. Tall Meadow Oat Grass per acre, or 8 ibs. Red Clover and 18 tbs. of Orchard Grass per acre. Orchard Grass sown alone requires $1 \frac{1}{2}$ bushels to 2 bushels per acre. For pastures Red Top, Kentucky Blue Grass, Canada Blue Grass, Rye Grasses, and Clovers are very desirable additions to Orchard Grass.

CHEROKEE BRAND-90\% Purity, 90\% Germination. This seed is radically recleaned, being of heaviest weight.

Postpaid-Lb. 25c; bushel $\$ 2.80$.

Express-Bushel $\$ 2.50 ; 8$ bus, at $\$ 2.40$ per bu. Domestic-80\% Purity; $90 \%$ Germination. Postpaid-Lb. 20c; bushel $\$ 2.50$.

Express-Bushel $\$ 2.25$; 8 bus. at $\$ 2.10$ per bu.

\section{Red Top or Herd's Grass}

A very hardy, native perennial grass well adapted for such a variety of situations that while succeeding best on moist lands, Red Top also flourishes in almost any soil and under all conditions, even withstanding hottest climates. Because it is perhaps our most permanent pasture grass every good hay and pasture mixture sown should contain a liberal quantity of this most excellent grass. It remains green for the greater part of the year, and its long trailing stems form a very close matting turf that is not affected by trampling. Sow 8 or $10 \mathrm{lbs}$. to the acre.

Postpaid-Lb. 35c; 10 los. $\$ 3.25$.

Express-Lb. 30 c ; 10 ibs. $\$ 2.70 ; 100$ lbs. $\$ 25.00$.

\section{Canada Blue Grass}

A very hardy perennial grass, with creeping root stocks. It grows on the poorest and driest soils, sandy, gravelly or clayey, standing extreme wetness or drought, and keeping green until severe frosts of winter. It is especially valuable for dairy pastures, cows feeding on it yielding the richest milk and the finest quality butter. It is distinguished from Kentucky Blue Grass by its flattened, wiry stems and decidedly blue color. Sow 28 ibs. per acre alone.

Postpaid-Lb. $40 \mathrm{c} ; 10$ Ibs. $\$ 3.50$

Express-Bus. $\$ 4.25 ; 50$ lbs. $\$ 15 ; 100$ ibs. $\$ 27.50$.

\section{Tall Meadow Oat Grass}

Tall Meadow Oat Grass is most highly esteemed for pastures on account of its early and luxuriant growth of an abundant supply of foliage, which is greatly relished by cattle both during early spring and autumn. It is the first green grass of spring, and seems to yield steady grazing until late fall, even during extreme drought or cold. For hay two cuttings may be made each season, and for green feed four or five cuttings may be had under favorable conditions. It matures with Orchard Grass and Red Clover, and mixed with these produces large yields of finest quality hay. All pasture mixtures shou'd be composed of a percentage of this excellent year-round grazing crop. Sow 25 or $30 \mathrm{lbs}$. to the acre in Spring or Fall.

Postpaid-Lb. 45c; bushel $\$ 4.50$.

Express-Bu. $\$ 4.00 ; 100$ lbs. $\$ 32.00$.

\section{Meadow Fescue or Randall Grass}

One of the grasses most used in permanent or temporary meadows for mowing or pasture. It succeeds best in cold moist light soils, in welldrained meadows and low valleys rich in organic matter. It reaches full development the second or third year, and then far exceeds most grasses in productiveness of a very superior feed, dry or green. After being mown it grows up quickly. It is highly relished by cattle and most nourishing. Sow 40 lbs. per acre.

Postpaid-Lb. 30c; 10 tos, $\$ 2.75$.

Express -10 to s. $\$ 2.50$; 50 lbs. $\$ 11.50$; 100 ibs. $\$ 22.00$

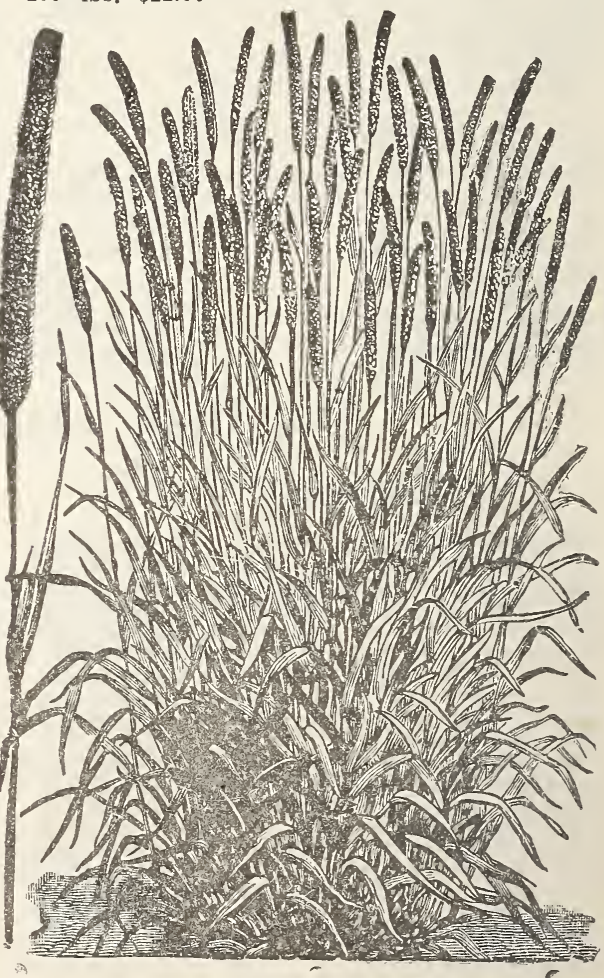

Timothy. 


\section{"CHEROKEE BRAND" GRASSES-Continued. \\ Wood Meadow Grass}

This grass is especially fitted for shaded positions in lawns and woodland parks, where other grasses will not grow. Very permanent and hardy, resisting extremes of heat and cold. One of the first grasses to show a rich growth in the Spring. Creeping roots are formed under ground, and make a good turf. Excellent for pasture.

Sow $30 \mathrm{lbs}$. to acre.

Postpaid-Lb. $\$ 1.50 ; 10$ lbs. $\$ 13.00$

Express-Lb. $\$ 1.40$; $10 \mathrm{lbs}$. $\$ 12.50$.

\section{Red or Creeping Fescue}

A creeping-rooted species forming a close and lasting turf, especially adapted for dry and sandy soils. Thrives on poor soils, gravelly banks and exposed hillsides. Valuable for shady places in lawns and golf courses. Sow $30 \mathrm{lbs}$. to acre. Postpaid-Lb. $\$ 1.00 ; 10$ lbs. $\$ 9.50$.

Express-Lb. $90 \mathrm{c} ; 10$ Ibs. $\$ 8.50$.

\section{Italian Rye Grass}

This grass resembles English Rye Grass considerably. It is a very valuable, vigorous growing grass, suitab'e for furnishing in a very short time a splendid green pasture. Also fine on lawns. It forms a good turf, and stands the dry weather remarkably well. This grass can be sown with success either in the fall of the year or very early spring. On rich land it will grow from 2 to 3 feet high. From 30 to $40 \mathrm{lbs}$. of seed should be used in seeding an acre.

Postpaid-Lb. 30c; 10 lbs. $\$ 2.50$.

Express-Lb. 25c; $10 \mathrm{lbs} . \$ 2.10 ; 100 \mathrm{lbs} . \$ 18.00$.

\section{Pacey's Perennial Rye Grass}

Sow 25 tbs. per acre.

This most valuable hay and pasture grass adapts itself to a great diversity of soils and should be largely used in permanent meadows of Western North Carolina. The seed is large and heavy, and produces a strong, vardant growth in four weeks after sowing. It matures into hay of the sweetest flavor, much relished by cattle and horses. It is largely used on lawns and golf courses.

Postpaid-Lb, 30c; 10 lbs. $\$ 2.75$.

Express-Lb. $25 \mathrm{c} ; 10 \mathrm{tbs}$ s. $\$ 2.25 ; 100$ tbs. $\$ 20.00$.

\section{Crested Dogstail}

A true perennial, forming a smooth compact and lasting turf. It thrives best on rich, moist land, but is well adapted for almost any soil. The roots penetrate deeply into the ground, which enables it to withstand severe drought. It is extremely valuable both for lawns and pastures as a bottom grass, and thrives well in the shade. It is sown at the rate of $30 \mathrm{lbs}$. per acre alone, but recommended only for use in mixtures.

Postpaid-Lb. $75 \mathrm{c} ; 10$ tbs, $\$ 7.00$

Express-Lb. $70 \mathrm{c} ; 10$ ibs. $\$ 6.75 ; 50$ lbs. $\$ 32.00$.

Perennial or English Rye Grass

An early maturing, quick growing grass, making fine grazing and hay. Excellent mixed with other

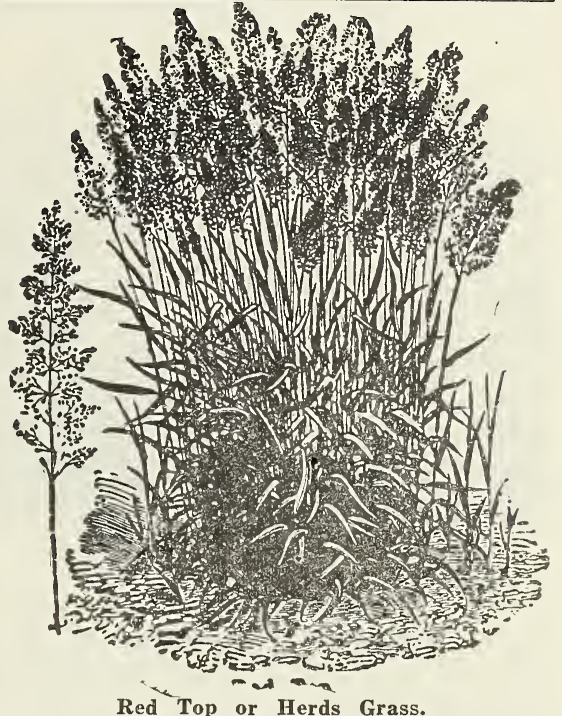

grasses, furnishing valuable permanent pasture and hay. It is also being largely sown in lawns. When sown alone, sow $30 \mathrm{lbs}$. to an acre.

Postpaid-Lb. $30 \mathrm{c} ; 10$ 1bs. $\$ 2.50$.

Express-Lb. $25 \mathrm{c} ; 10 \mathrm{lbs} . \$ 2.10 ; 100$ lbs. $\$ 18.00$.

\section{Sheep's Fescue}

Sheep's Fescue prefers dry uplands and thrives in poor shallow soils when other grasses fail. It is very hardy, resisting cold or extreme heat. Although of dwarf habit, it grows thickly, yielding large quantities of nutritious feed. It is largely used on lawns and golf courses on account of its fine foliage and dense dwarf growth. Sow $30 \mathrm{lbs}$. per acre.

Postpaid-Lb. 65c; 10 Ibs. $\$ 6.25$.

Express -10 ibs. $\$ 6.00 ; 50$ tbs. $\$ 27.50$.

\section{Bermuda Grass}

This is a most valuable grass for pasturage, hay, lawns, etc., in the lowlands of the South, where other grasses do not grow well due to the extreme heat. It stands hot weather remarkably well. We do not advise sowing it in the mountain section of Western North Carolina, except for hillsides and railway embankments, to keep them from washing. The seed should be sown broad cast 6 to 8 tbs. to acre from end of March to July. Do not sow too early, as the seed will not germinate in cool weather. Cover seed lightly, not more than half an inch. As this grass is very hard to eradicate it should not be used for temporary pasture.

Postpaid-Lb. 50c; 10 ibs. $\$ 4.50$.

Express-Lb. $40 \mathrm{c} ; 100$ 1bs. $\$ 37.50$.
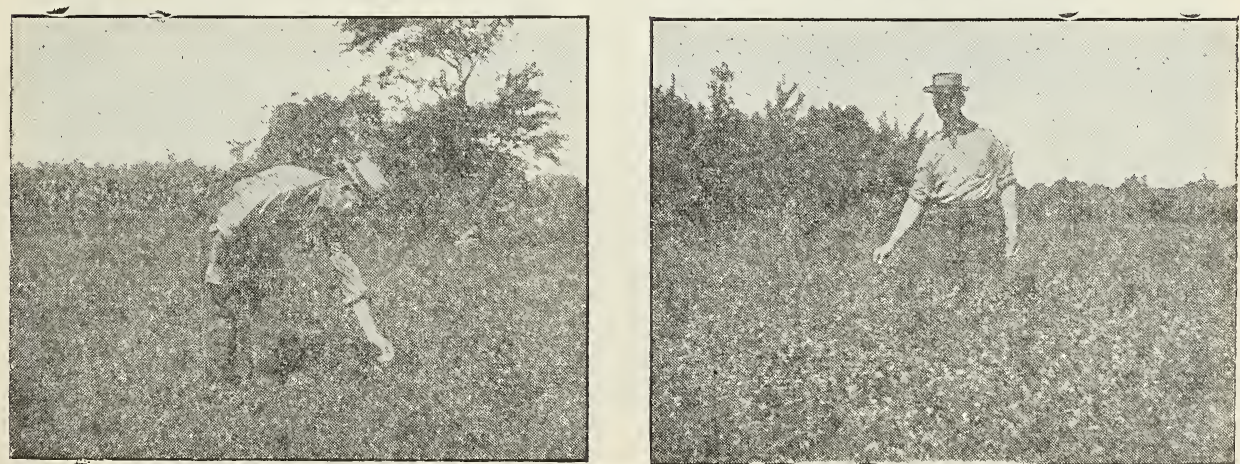


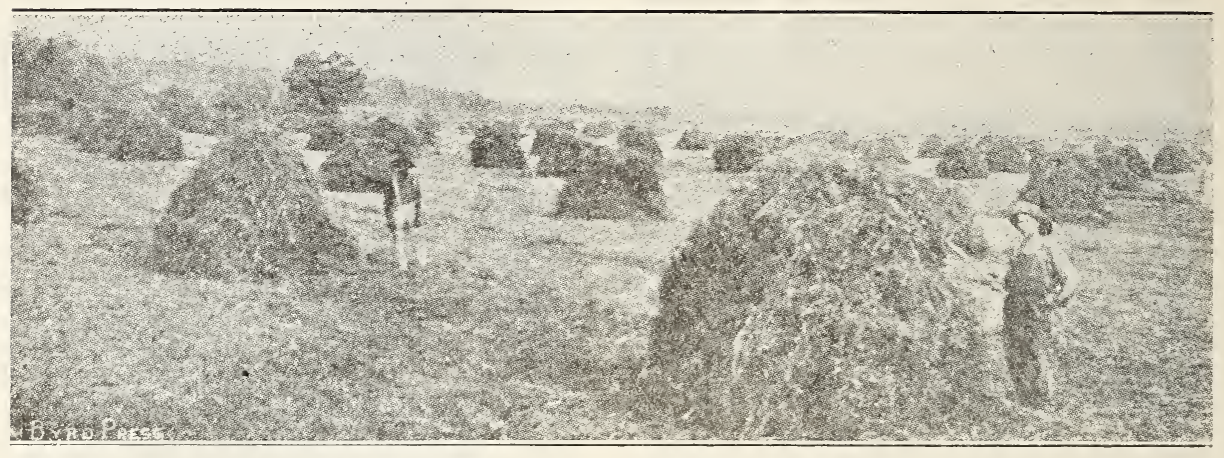

\section{Permanent Pasture and Hay Mixtures}

It has been proven conclusively that many kinds of grass and clover seeds mixed together in proper proportion will produce on any soil a much larger yield and a more nutritious crop. It will give more cuttings and a longer period of grazing. Where a single grass is sown there will be vacant places that will fill up with weeds, while in a mixture there is seed adapted to all soils and as a result the whole surface will be covered with good grasses. Each and every variety of grass has its peculiar characteristics, some will withstand extreme drought, some are early and some are late and as a result a well-balanced mixture will give a green pasture under all conditions.

Our "CHEROKEE PASTURE MIXTURE" for upland and lowland is a mixture best adapted to the soils of Western North Carolina, and many of our customers that bought at first in small quantities are now sending us large repeat orders. The mixtures are giving the greatest satisfaction. When ordering please state whether for upland or lowland. Sow 30 to 35 pounds to the acre.

We have other formulas suitable for the soil and climatic conditions of all other parts of the South. If you will send us a sample of your soil, a little taken from several places and mixed together, we will be glad to test it for you and to recommend just what your soil needs, and what seeds are best adapted.

\section{Cherokee Pasture and Hay Mixtures}

\section{UPLAND}

Postpaid-Lb. $35 \mathrm{c} ; 10$ tbs. $\$ 3.25 ; 25$ tbs. $\$ 7.50$. Express -10 1bs. $\$ 3.00 ; 50$ tbs. $\$ 13.00 ; 100$ tbs. $\$ 25.00$

\section{LOWLAND}

Postpaid-Lb. 35c; 10 ths. $\$ 3.25 ; 25$ tbs. $\$ 7.50$. Express-10 1bs. $\$ 3.00 ; 50$ tbs. $\$ 13.00 ; 100$ tbs. $\$ 25.00$

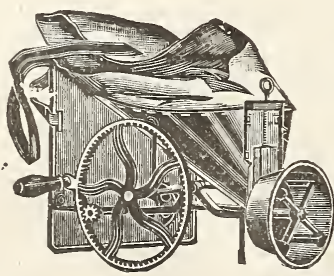

\section{Cahoon Broadcast Seed Sower} FOR SOWING GRASS SEED, GRAIN, CLOVER SEED

The best seeder manufactured. Sows all kinds of grain, clover, etc., rapidly and evenly. A person entirely unused to seeding can, by following the simple directions sent with machine, sow from four to six acres an hour at a common walking gait. It sows uniformly and saves four fifths in labor by its use. Every farmer should have one of these sowers. Circulars giving full information and directions for use, mailed on application. Price-\$4.00. Postpaid-\$4.25.

\section{SPECIAL MIXTURES}

Postpaid-Ib, 35c: 10 tbs $\$ 3.25 \cdot 25$ tbs. $\$ 7.50$ Express-10 tbs. $\$ 3.00 ; 50$ tbs. $\$ 14.00 ; 100$ tbs. $\$ 27$

\section{TIMOTHY AND CLOVER MIXTURES}

Postpaid-Lb. 25c ; 10 tbs, $\$ 2.25$. Express -10 tbs. $\$ 2.00 ; 100$ Ibs. $\$ 18.00$.

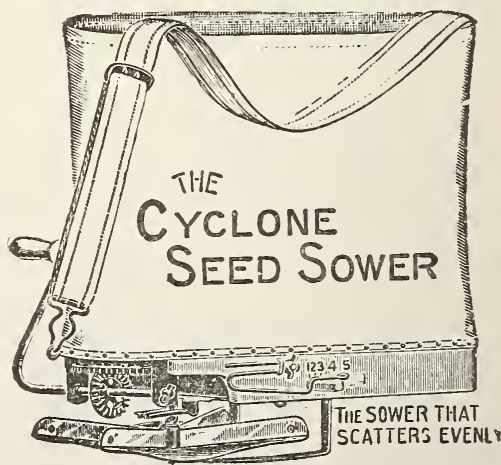

\section{Cyclone Seed Sower}

This sower :s guaranteed to distribute seed perfectly and evenly, will not throw seed in an upwar direction or against the operator, but direct and evenly to the land; sows clover, timothy, red top or herds grass, oats, millets, sorghum cane, rye, wheat, buckwheat, turnip and other seeds that are sown broadcast. Time and money can be saved by the use of this sower.

Price- $\$ 2.00$ each. Postpaid- $\$ 2.25$. 


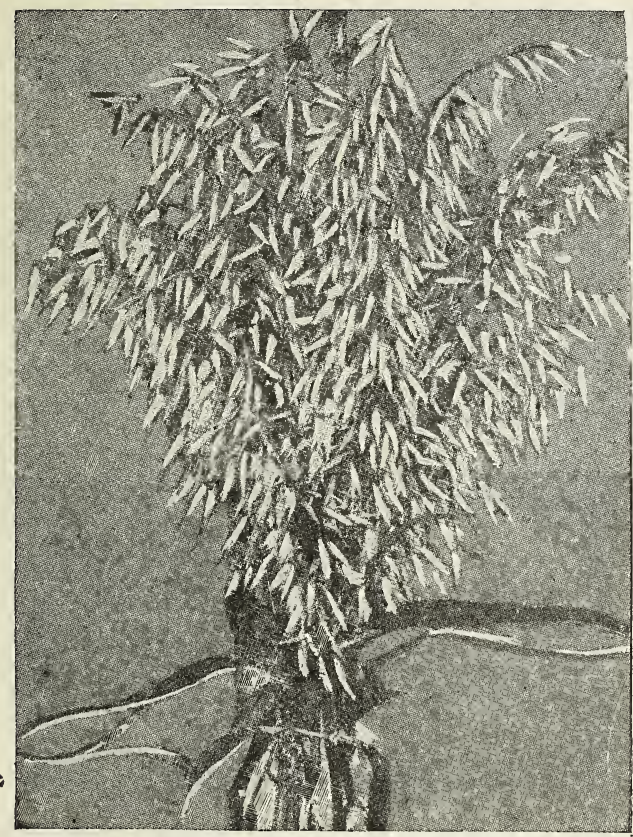

Extra Early Burt, or 90-Day.

\section{Sudan Grass-The Ideal Hay Crop}

THIS NEW REMARKABLE HAY AND FORAGE CROP has created a sensation among the planters wherever sown on account of the universal success attained with it. Its adaptability to various kinds of soils and climates; its wonderfully heavy yielding qualities of abundance of good nutritous feed.

SUDAN GRASS AT A GLANCE - From Farmers Bulletin 605, Department of Agriculture: "Sudan Grass is related to the cultivated sorghums and is thought by some to be the progenitor of this group. It was obtained from Khartoum, Sudan, in 1909. In appearance it is similar to Jolinson Grass, but it is somewhat more erect, taller, and has a broader leaf. It lacks entirely the underground root stocks which make Johnson Grass a pest. Two or three cuttings can be obtained from it under favorable conditions. The y:elds vary from 1 to 8 tons of cured hay per acre. It promises to fill a long-felt want for a hay grass in the South, and will likely replace millets as a catch crop in the Central and Eastern States."

SOWING THE SEED-The seed should not be sown in this section until the weather becomes warm, about the first of May. Can be sown in drills or broadcast. When in drills about 2 feet apart, it requires about 10 tbs. of seed to an acre. If broadcast or drilled thickly, 25 to $30 \mathrm{lbs}$. to an acre is required. Postpaid-Lb. $20 \mathrm{c} ; 10$ lbs. $\$ 1.50 ; 25$ tbs. $\$ 3.25$. Express-Lb. $15 \mathrm{c} ; 10$ lbs. $\$ 1.25 ; 100$ los. $\$ 11$.

\section{Golden or German Millet}

TENNESSEE GOLDEN MILLET-Makes a large crop of most nutritious hay; rapid grower, and easily cured. Sow about $11 / 2$ bushels per acre from April to August, cut the hay before the heads form. Our Tennessee grown Millet not only produces a large crop but a better quality of hay than the Western seed.

Postpaid-Lb. 20c; 10 lbs. $\$ 1.00$.

Express-10 lbs. 85c; bushel $\$ 3.50$.

\section{SEED OATS}

Oats should be sown in March and April and at the rate of 2 to 3 bushels to the acre, since they do not have time to stool as oats sown in the fall do.

We sell only tested seed and the pick of the crop; they insure a better stand and better yield.

BURT or 90-DAY OATS - This is unquestionably the quickest growing, most prolific, and surest cropping of all spring oats. It is a sure header, early maturing (about two weeks earlier, than other varieties) and is rust-proof. The healthy, clean and vigorous growth produces an abundant yield of bright, heavy grain. Burt Oats are especially adapted for poor soils.

Postpaid-Peck 40c; bushel $\$ 1.30$.

Express-Bu, 90c; 5 bu. at $85 \mathrm{c}$ per bu.

Price fluctuates. Write for firm price.

RED RUST PROOF-Red Rust Proof produces a large yield of heavy, fine appearing grain. They also grow well in poor soil.

Postpaid-Peck $40 \mathrm{c}$; bushel $\$ 1.30$.

Express-Bu. 90c; 5 bu. at $85 \mathrm{c}$ per bu.

Price fluctuates. Write for firm price.

WHITE SPRING OATS-A very popular variety in Western North Carolina. It is an excellent yielder of bright, clean grain; is extremely hardy and grows taller than other varieties.

Postpaid-Peck 35c; bushel $\$ 1.20$.

Express-85c; $5 \mathrm{bu}$, at $75 \mathrm{c}$ per bushel.

Prices approximate only-Write for price.

\section{Virginia Gray or Winter Turf Oats}

The wide popularity of Winter Turf Oats is probably due to their hardiness, since there is other variety that can withstand such extreme cold. Experiments in practically all climates prove that these Oats seldom winter kill. It has remarkable stooling tendencies and is a heavy yielder of bright grain which very often weighs 35 to 40 pounds per bushel. We cannot recommend this variety too strongly, especially to farmers of Western North Carolina.

Postpaid-Peck $45 \mathrm{c}$; bushel $\$ 1.65$.

Express-Bushel about $\$ 1.25 ; 5$ bushels at $\$ 1.10$ per bushel. Prices fluctuate.

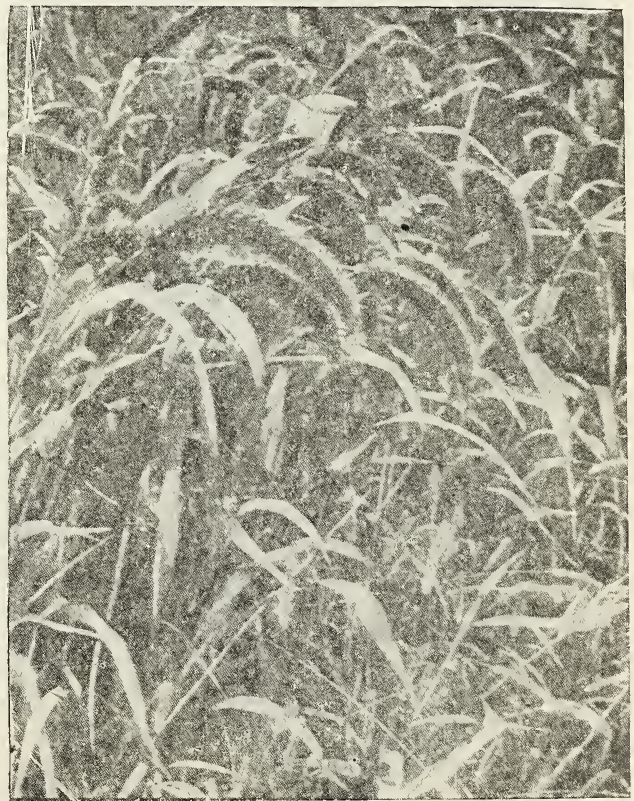

Golden or German Millet 


\section{IMPROVED OR SELECTED SEED CORN}

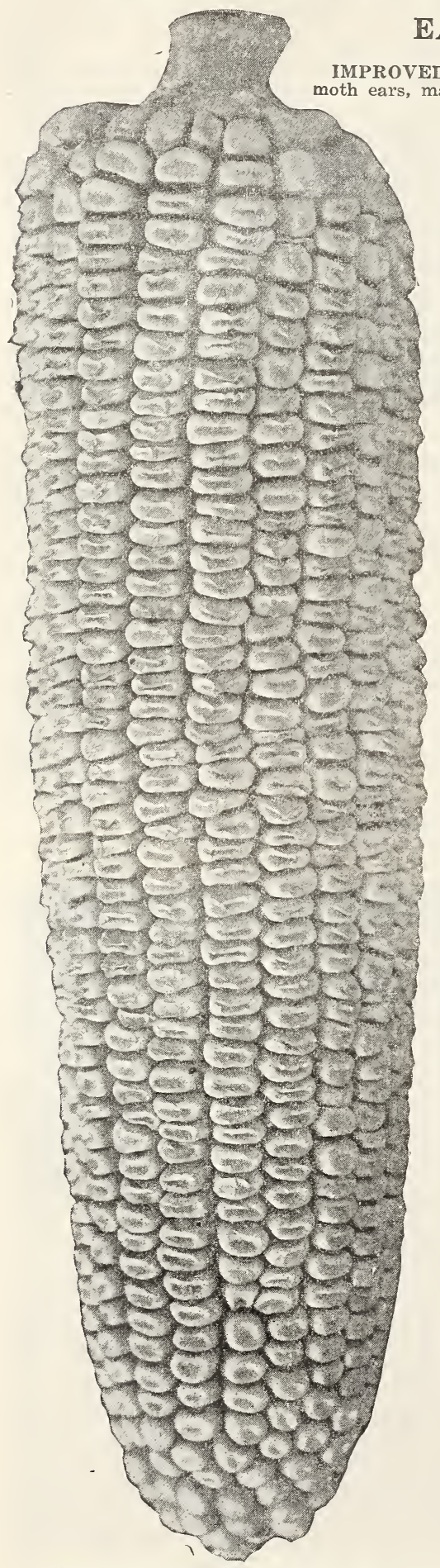

IMPROVED EARLY GOLDEN DENT COON

\section{EARLY MATURING VARIETIES}

IMPROVED EARLY GOLDEN DENT CORN-This produces mamto 110 days.

It makes a beautiful ear, well filled, with deep golden yellow kernels, medium wide and firmly set on a small cob. No matter whether shelled or on the cob, no yellow corn is more attractive. The stalks are robust and grow from 8 to 10 feet high. The shuck is close and completely protects the tip from wet weather. In fact no matter how wet the weather it does not seem to hurt it. Produces one to two ears to the stalk. This seed is grown in Buncombe County under our supervision : selected in the field, hand shelled, nubbed at both ends.

Postpaid-Lb. $15 \mathrm{c}$; peck $\$ 1.10$; bu. $\$ 3.65$.

Express-Lb. $10 \mathrm{c}$; peck $90 \mathrm{c}$; bu. $\$ 3.00$.

EARLY WHITE SNOW FLAKE-This variety is undoubtedly the earliest large corn in cultivation. The grain is deep white; cob small, white, sometimes running as much as 90 per cent grain. The average length of the ear 8 to 11 inches, and the stalk is low, averaging about 7 to 8 feet. The ear is usually borne close to the ground. This variety admits of close cultivation, and, in our judgment, is one of the most profitable corns that can be grown for main crop. It has been known to make a roasting ear in 60 days after germinating. It will always be hard enough to grind in 90 to 120 days. It is largely used throughout the South for planting as late as July.

Postpaid-Lb. $15 \mathrm{c}$; peck $\$ 1.10$; bu. $\$ 3.65$.

Express-Lb. $10 \mathrm{c}$; peck $90 \mathrm{c}$; bu. $\$ 3.00$.

CHAMPION EARLY WHITE DENT CORN-Matures in 90 to 100 days. This variety is always ready for feeding, husking, and marketing earlier than any other of the standard varieties of white corn by fully two weeks. Stalk of medium height ranging from 7 to 10 feet high (dependent upon the land, hill or bottom ground). The type of this corn is very even and uniform; large ears run from 9 to 12 inches long; 16 to 22 rows of pure white kernels; ears well filled out at butt and tip ends.

Postpaid-Lb. 15c; peck $\$ 1.10$; bu. $\$ 3.65$.

Express-Lb. 10c; peck 90c; bu. $\$ 3.00$.

BOONE COUNTY WHITE CORN-It is a splendid vielder. In many places it is a great favorite. Highly recommended for an early maturing, heavy yielding corn for uplands or good light loam soils. The ears are from 9 to 12 inches long, $7 \frac{1}{2}$ to $8 \frac{1}{2}$ ins. in circumference, containing 18 to 24 rows. The cob is medium size, and pure white in color. The ears are quite uniform in size, shape and appearance. Kernels are pearl white, quite deep. This variety grows a large stalk from 10 to 12 feet high, with an abundance of foliage, and like other white varieties, is the best for old, thin, poor soils. They gather more plant food from the air and less from the soil than does the yellow corn.

Postpaid-Lb. 15c; peck $\$ 1.10$; bushel $\$ 3.65$.

Express-Lb. 10c; peck 90c; bushel $\$ 3.00$.

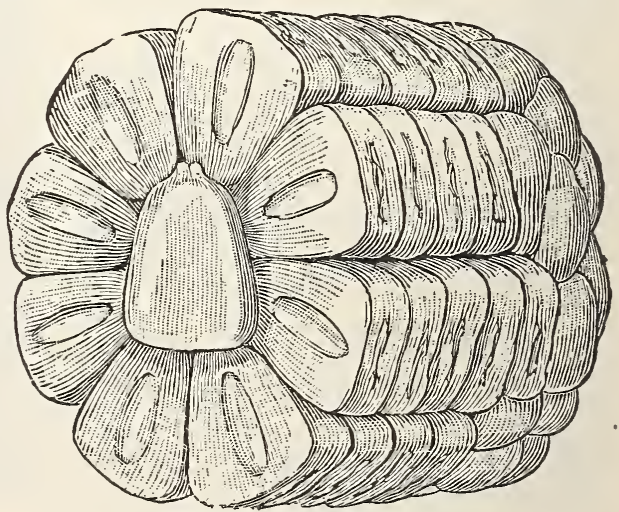

HICKORY KING CORN 
IMPROVED SELECTED SEED CORN-Continued.

\section{Later or Main Crop Corns}

HORSE TOOTH ENSILAGEHorse Tooth indicates the shape and depth of the grain. This is a splendid yielding field corn. Very popular among dairymen.

Postpaid-Lb. 15c; peck $\$ 1.10$; bushel $\$ 3.65$.

Express-Lb. 10c; peck 90c; bushel $\$ 3.00$.

HICKORY KING CORN-A medium early, prolific variety, with very broad and firm flat grain. The ears average about 8 inches long. The cob is exceedingiy small, not much larger than a man's finger, and has 10 or 12 rows; will make fine roasting ears. For the production of meal it is not excelled by

any sort. It is especially recommended for high land.

It can be depended upon to produce a crop on poor, thin land; on good land it bears two ears to the stalk. Our seed is grown in Buncombe County; under our own supervision, selected in the field, hand shelled, nubbed at both ends.

Postpaid-Lb. 15c; peck $\$ 1.10$; bushel $\$ 3.65$

Express-Lb. 10c; peck $90 \mathrm{c}$; bushel $\$ 3.00$.

TENNESSEE RED COB WHITE CORN - An extra large field corn; grain long, broad and evenly lined on large red cob. The ears of this sort will run from 9 to 12 inches long, and have from 18 to 22 rows. It is rather a late maturing sort, but for bottom land or a main crop, this corn cannot be excelled. Our seed of this variety is grown in Tennessee, in the Tennessee River Valley, and is undoubtedly the highest developed type of this class of corn that can be obtained.

Postpaid-Lb. 15c; peck $\$ 1.10$; bushel $\$ 3.65$.

Express-Lb. 10c; peck 90c; bushel $\$ 3.00$.

KENT'S PROLIFIC-Has been grown on the Kent Farms, Buncombe County, for 20 years. It can be relied upon to produce from 2 to 5 ears to the stalk. Grain white and flinty nature, making fine hominy and excellent meal. It is selected in the field, hand shelled, nubbed both ends, and without doubt one of the best seed

The supply is limited.

Postpaid-Lb. 15c; peck $\$ 1.25$; bushel $\$ 4.50$.

Express-Lb. 10; peck $\$ 1.00$; bushel $\$ 3.75$.

BOONE COUNTY WHITE CORN

\section{Pop Corn}

A PROFITABLE CROP-Boys and girls can easily grow an acre or so and dispose of the product to the groceryman.

WHITE RICE-A very handsome and very prolific variety. Ears short; kernels long, pointed and resemble rice; color white. No variety of Pop Corn is superipr to this for popping.

Postpaid-Pkt. 10c; $1 / 2$ tb. 15c; 1b. 25c; 15 Ibs. $\$ 2.25 ; 50$ ibs. 5.75 .

Express-Pkt. 10c; 1/2 1b. 10c; 1b. 15c; 15 tbs. $\$ 2.00 ; 50$ tbs. $\$ 5.00$.

QUEEN'S GOLDEN-This is a large-eared and handsome Pop Corn. The grains are large, pop perfectly white, and are exceedingly tender. The stalks grow about 6 feet high, and yield 3 or 4 ears each.

Postpaid-Pkt. 10c; 1/2 tb. $15 \mathrm{c} ;$ tb. $25 \mathrm{c} ; 15$ ibs. $\$ 2.25 ; 50$ ibs. 5.75

Express-Pkt. $10 \mathrm{c} ; 1 / 2$ 1b. $10 \mathrm{c} ; 1 \mathrm{~b} .15 \mathrm{c} ; 15$ ibs. $\$ 2.00 ; 50$ tbs. $\$ 5.00$.

LITTLE BUSTER-A White Rice Pop Corn, especially screened for popping machines.

Express-100 Ib. bag $\$ 8.00$.

Price fluctuates. Write.

\section{Vetch}

HAIRY or SAND VETCH-Has become very popular in the South as a land improver. It is also fine for hay and grazing, all kinds of stock relish it. While it is in bloom, bees make more than double as much honey, as at any other time. The honey is white and clear and of excellent quality. It grows well on all soils and does surprisingly well on poor, thin land. It withstands drought and extremes of heat and cold. It reseeds itself, coming year after year from one sowing. It has a wonderful value as a fertilizer. Sow early in the spring 20 pounds to an acre with 1 to $1 \frac{1}{2}$ bushels Red Rust Proof Oats, or you may sow in the fall to make hay about the end of May. It never winter kills. Alone sow about 50 pounds to the acre.

Past season crop was short and price very high. Prices fluctuates. Will quote in any quantity op application.

OREGON SPRING VETCH-This crop has been largely grown on the Pacific Coast and has only recently been planted to a large extent in the South. It is an excellent soil improver as well as a nutritious hay and grazing crop. We recommend sowing 30 ibs. Vetch with 1 bushel Oats for grazing.

Write for prices. 


\section{Miscellaneous Forage Crops \\ Buckwheat}

This is a late summer crop that is very desirable for mountain sections. Buckwheat is largely grown for bees and grain. It is often planted as a soil improver to turn under or as a sure means of smothering out weeds.

JAPANESE-This is the earliest variety and possibly the best for the South. It is a prolific yielder of unusually large kernels, and has good branching qualities.

Postpaid-Lb. 15c; 10 1bs. 90c.

Express-10 1bs. $75 \mathrm{c}$; bushel $\$ 2.75$.

Mangel-Wurtzel or Stock Beets

One ounce for 50 feet of drill; $5 \mathrm{lbs}$. for one acre.

MAMMOTH LONG RED-On good soil sometimes grows 18 inches long. Dark leaves; skin bright dark red; flesh white with veined rings of rose-pink. An excellent keeper; nutritious and milk-producing.

Postpaid-Oz. 10c; 1/4 Ib. 20c; th. 70c.

Express-Lb. 60c; $5 \mathrm{lbs}$. and over at $50 \mathrm{c}$ per $1 \mathrm{~b}$.

WHITE FRENCH SUGAR - A white fleshy, handsome and very productive strain, skin below ground rose-colored, top gray.

Postpaid-Oz. $10 \mathrm{c} ; 1 / 4$ ib. $20 \mathrm{c} ;$ th. $70 \mathrm{c}$

Express-Lb. 60c; 5 Ibs. and over at 50c per th.

GOLDEN TANKARD-A yellow-fleshed variety,

highly prized by dairymen for milk-producing qualities.

Postpaid-Oz. 10c; 1/4 tb. 20c; tb. $70 \mathrm{c}$

Express-Lb. $60 \mathrm{c} ; 5 \mathrm{Ibs}$. and over at $50 \mathrm{c}$ per $1 \mathrm{tb}$

\section{Seed Rye}

Rye may be sown any time from July to Dec., before freezing weather sets in. On poor land sow early. It produces green food earlier in the spring than any other grain.

ABRUZZI RYE-The best rye for lighter lands. Gives a quick, vigorous growth with large well filled heads. Matures earlier than common rye. Write for prices.

MOUNTAIN RYE-This rye is much hardier than the Abruzzi Rye, as it stands the severe winter without injury.

Write for prices.

\section{Sorghum Cane}

EARLY ORANGE-Strictly a forage crop like Amber Cane, considered by many to be the best yielder of all the cane forage crops; is medium late, and produces large stalks.

Postpaid-Lb. 15c; 10 lbs. $\$ 1.15$.

Express-Bushel $\$ 3.50$.

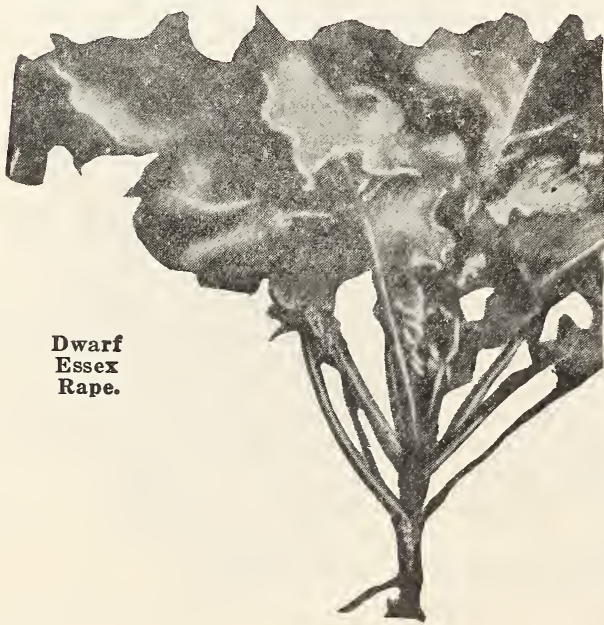

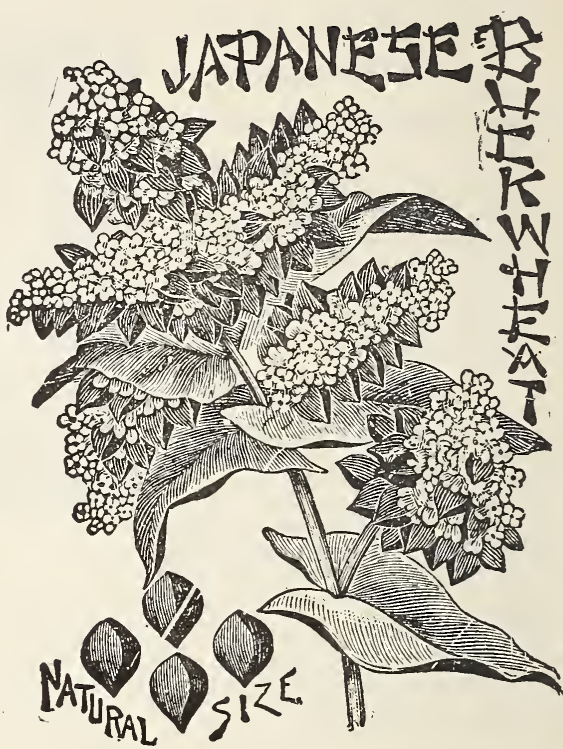

EARLY RED TOP SORGHUM-A late variety producing very large stalks and more syrup. Largely utilized as a green hog feed.

Postpaid-Lb. 15c; 10 Ibs. \$1.15.

Express-Bushel $\$ 3.50$.

EARLY AMBER-Produces a large yield of nutritious hay; grows 10 to 12 feet high, has excellent stooling tendencies, can be cut 2 or 3 times for hay. An excellent green or cured feed. Broadcast $1 \frac{1}{2}$ bushels to acre.

Postpaid-Lb. $15 \mathrm{c} ; 10$ lbs. $\$ 1.15$.

Express-Bushel $\$ 3.50$.

JAPANESE SEEDED RIBBON-This is the very best variety for syrup. It produces a large yield of syrup, the flavor of which is superior to all other varieties on the market.

Postpaid-Lb. 20c; 10 1bs. $\$ 1.75$.

Express-Bushel $\$ 4.50$.

BEARDLESS SPRING BARLEY-This variety sown in the spring matures as quickly as winter barley sown in the fall. It supplies fine green forage for cattle and poultry and also makes excellent hay. Can be sown with rye, vetch, and rape for spring grazing.

Postpaid-Lb. 15c; 10 tbs. $\$ 1.00$.

Express-Peck 65c; bushel $\$ 2.00$.

BROOM CORN (Improved Evergreen)-This is the best variety for the South, is tall and straight, fine green appearance when cured. Plant 10 to 15 tis s, to the acre in rows 3 feet apart; cultivate early and often. Harvest when seed becomes soft and milky.

Postpaid-Lb. 25c; 10 fbs. $\$ 1.90$.

Express-10 1bs. $\$ 1.55 ; 100$ tbs. $\$ 12.00$.

\section{Dwarf Essex Rape}

Rape is one of the quickest and cheapest pasture crops for sheep, young cattle, poultry and hogs. Sown in the same manner as turnips, in drills or broadcast. When sown in drills, 5 tbs. to an acre is used; if sown broadcast, it requires $10 \mathrm{lbs}$. to an acre.

Postpaid-Lb. 20c; 10 1bs. $\$ 1.75$.

Express-10 1bs. $\$ 1.50 ; 100$ tbs. $\$ 12.00$. 


\section{All Valuable Leguminous Plants and Summer Forage Crops}

\section{Soy or Soja Beans}

The cultivation of this crop is increasing rapidly, due to its value and importance for a forage crop and soil improver. Soy beans are also valuable to the Southern farmer, as they resist the drought and hot weather to a great extent. Soy Beans are practically the only crop that furnishes a balanced ration feed in one crop. Both the forage and bean crop are very nutritious; can be sown in drills $3 \frac{1}{2}$ feet apart at the rate of $1 / 2$ bushel to 3 pecks to an acre or broadcast $11 / 2$ busels to an acre. Thick sowing prevents stalks from growing too coarse. Often successfully sown with cow peas, mixing $1 / 2$ bushel Soy Beans to 1 bushel of cow peas to an acre. We list below the most popular varieties.

WILSON EARLY BLACK SOY-A very early variety, also very prolific. Has fine stems which enable it to cure for hay quicker than other varieties.

Price fluctuates-Write.

MAMMOTH YELLOW SOY (SOJA)-This variety we consider especially valuable for this section and farther south. It makes the largest yield of forage and beans of any of the known varieties.

Price fluctuates-Write.

MAMMOTH BROWN SOY-This variety is very well adapted to this locality and has been sown with fine results. Fully as prolific as the Mammoth Yellow. Price fluctuates-Write.

\section{Peanuts}

Culture-Shell the nuts and plant in April or May in drills $21 / 2$ to 3 feet apart, dropping them 12 to 15 inches apart in the drill. Work occasionally, cultivating flat and keeping the land clean of weeds.

SPANISH-An early small-sized variety which is enormously prilific, and the kernels are very rich and fine flavored. It is also very largely grown for stock-feeding, the vines and roots pulled up and cured making excellent, nutritious hay or very fattening hog food.

Postpaid-Lb, 30c; 10 Ibs. $\$ 1.90$.

Express-25 1bs. $\$ 3.75$.

IMPROVED LARGE VIRGINIA-A very profitable variety to grow, and is easily cultivated; very erect: largest pods and kernels with fewer imperfect pods than any other variety. "The vines make valuable forage for stock.

Postpaid-Lb. 25c; 10 Ibs. $\$ 2.25$.

Express-25 tbs. $\$ 3.50$.

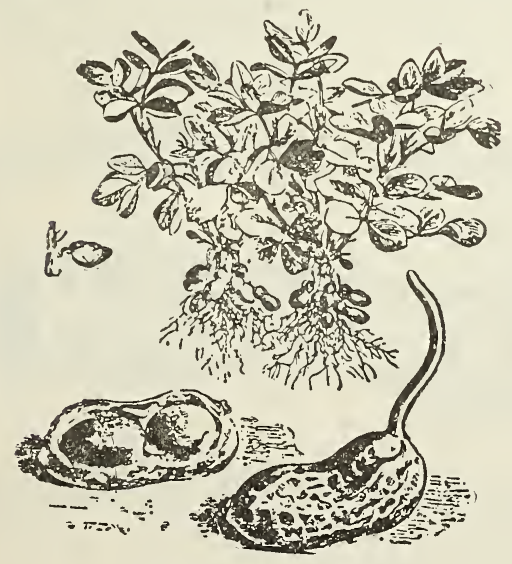

SPANISH PEANUTS

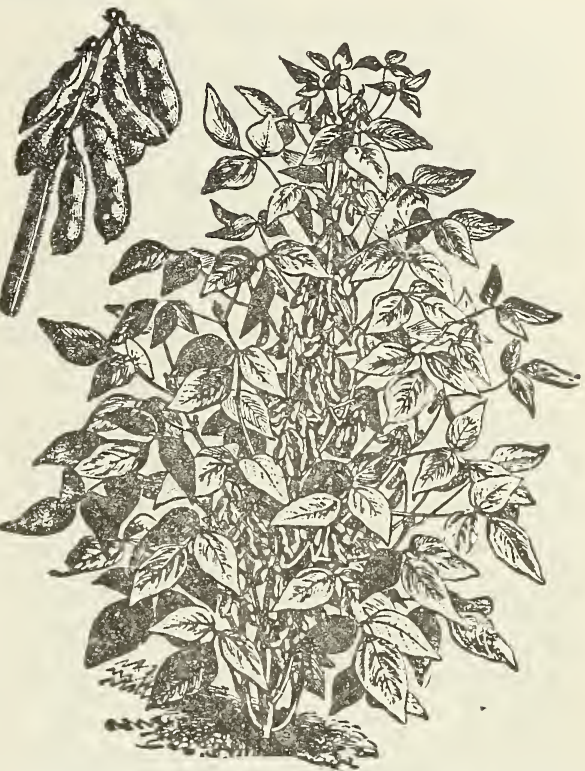

MAMMOTH YELLOW SOY OR SOJA BEANS

\section{Field or Cow Peas}

\section{AND FORAGE CROPS}

The South's Great Soil Improver Hay

COW PEAS are too well known to give space to the value as a hay ensilage crop, their high feeding qualities and their great power of enriching the soil. We list the popular varieties below.

C L A Y - Very similar to the Unknown, but earlier; vigorous growth, very popular.

Price fluctuates-Write.

WHIPPOORWILL-An upright growing variety. Early. Has brown speckled seed, which are easily gathered. Produces good vine growth.

Price fluctuates-Write.

IRON COW PEAS-A very early, small clay colored hard pea, of vigorous growth and diseaseresistant qualities; very prolific bearer.

Price fluctuates-Write.

BRABHAM-This variety is better adapted for light soils than heavy soils. It has proven in a number of tests to give larger yields of forage and peas than any other variety on the market.

Price fluctuates-Write.

MIXED COW PEAS-Preferred by many farmers where the crop is intended for soil-improving; they will grow thicker than separate varieties, producing better crop of vines and forage.

Price fluctuates-Write.

\section{Velvet Beans}

The Greatest Enriching Crop

100-DAY VELVET BEANS-This new variety is the quickest growing, earliest maturing of the Velvet Beans, making it possible to grow with success in North Carolina, Virginia and Tennessee, Velvet Beans thus giving the benefit to the soil that no other crop can give, far surpassing the Cow Peas for this. In addition to being a soil-improver crop, the 100-Day Velvet Beans make one of the best grazing crops for cattle. Velvet Beans are best planted in rows about 4 to 5 feet apart, at the rate of about $1 / 2$ bus. to acre. Price fluctuates-Write.

Inoculate this seed with Farmogerm. 


\section{High Grade Fertilizers}

\section{Pure Raw Bone Meal}

Our Bone Meal is made from pure, raw bones and contains a higher percentage of plant food than that prepared from steamed bone. We guarantee our Bone Meal to analyze 24 per cent Phosphoric Acid and not less than 41/2 per cent Ammonia. Bone Meal is an excellent fertilizer for all kinds of fruit trees, rose bushes, grape vines, bulbs, geraniums, ferns, palms, and other potted plants; and for grass crops. Whether for pasture, hay or lawn, Bone Meal will be found not only a valuable fertilizer, but a cheap one. It dissolves gradually, supplying food steadily during the growing season.

Price-Pkt. $\$ 1.00 ; 50$ tbs. $\$ 2.00 ; 100$ tbs. $\$ 3.50$; 200 lbs. $\$ 6.50 ; 1,000$ 1bs. $\$ 31.00$; ton $\$ 60.00$.

\section{PULVERIZED SHEEP MANURE}

A pure natural manure, free from all noxious weeds, and unequaled as a fertilizer for lawns, potted plants, vegetables, flowers, etc. It furnishes a natural humus to the soil, giving immediate and lasting results. We do not hesitate to recommend this excellent fertilizer as a good general source of high grade plant food; it will keep your lawns and plants green and flourishing during the growing seasons and protects them during the winter.

Price-Pkt. 50c; 50 tbs. $\$ 1.75 ; 100$ lbs. $\$ 3.00$; 500 lbs. $\$ 14.50 ; 1,000$ ibs. $\$ 28.00$.

Special price to florists, park owners, etc., on carload lots.

COW or CATTLE MANURE (Shredded)

It has been well said that one sack of this is equal to one carload of cow manure; is especially good for lawn, plant, and greenhouse fertilization. It is clean and convenient to handle.

Price-Pkt. $50 \mathrm{c} ; 50$ 1bs. $\$ 1.50 ; 100$ lbs. $\$ 2.75$; 500 tbs. $\$ 13.00 ; 1,000$ tbs. $\$ 25.00$.

\section{Acid Phosphate}

Many Southern soils lack available phosphoric acid in lime, hence for this reason Acid Phosphate is an almost indispensable fertilizer. Although it is an excellent fertilizer for general crops, its principal value is a grain and grass fertilizer. Apply from 200 to $400 \mathrm{lbs}$. per acre and mix well with soil 2 or 3 weeks prior to seeding for best results.

Analysis: 16\% Available Phosphoric Acid.

Price 200 1b. bag $\$ 2.00$; Ton $\$ 19.00$.

Special prices in larger quantities.

\section{BASIC LIME PHOSPHATE}

For Grain and Clover Crops

This fertilizer is more readily available as plant food than other phosphates, as it contains a large percent of lime. It sweatens acid soils and should be applied liberally where grain and clovers are to be grown. It will greatly increase the yield of wheat and rye. Apply from 400 to $600 \mathrm{lbs}$. to the acre.
Analysis: $13 \%$ available Phosphoric Acid. $30 \%$ Lime ; $8 \%$ Sulphur.

Price- $\$ 2.50$ per 200 lb. bag; ton $\$ 22.50$.

Special prices in larger quantities.

\section{Grain and Grass Fertilizer}

This is a quick acting and lasting fertilizer, especially prepared for grain and grass crops. The great popularity of this fertilizer is due to the increased production of crops and the permanent improvement of the soil that has resulted by its use. Apply 200 to $400 \mathrm{lbs}$. to the acre.

Analysis: Ammonia, 2 per cent; available Phosphoric Acid, 8 per cent; Potash, 2 per cent.

Price- $\$ 3.25$ per 200 ib. bag; $\$ 31.00$ per ton.

\section{High Grade Vegetable}

Apply 400 to $500 \mathrm{Ibs}$. to the acre.

This complete fertilizer is especially prepared for beans, peas, cabbage, tomatoes, melons, and other vegetables. The ingredients dissolve quickly and supply available plant food immediately, producing wonderful results by the stimulation of the vegetable plants into a luxuriant growth.

Analysis: Ammonia, 3 per cent; available Phosphoric Acid, 8 per cent; Potash, 5 per cent.

Price-100 1bs. $\$ 2.25 ; 200$ tbs. $\$ 4.00$; ton $\$ 39.00$.

\section{Potato Fertilizer}

Highly recommended both for Irish and Sweet Potatoes and other root crops. It seems to be the most desirable fertilizer for root crops that can be had today, invariably increasing the yield per acre and the quality of the crop. It contains from 2 to 3 per cent Potash, 10 per cent available Phosphoric Acid, 2 per cent Ammonia.

Apply 500 to 600 lbs, per acre.

Price -100 tbs. $\$ 2.00 ; 200$ tbs. $\$ 3.75$; ton $\$ 35$.

\section{Tobacco Dust}

The high percentage of Potash and Ammonia in this excellent fertilizer renders it invaluable for mulching, covering lawns, etc. It will soon rid your lawn of ants. It is also burned for fumigation purposes.

Price-10 tbs. $50 \mathrm{c} ; 25$ tbs. $\$ 1.00 ; 100$ tbs. $\$ 3.00$. GROUND LIMESTONE

We are agents for the Blue Ridge Lime Company and handle their limestone exclusively. We advise the liberal use of this product, as the soil in this locality needs it badly. We are in a position to quote you on any quantity you may desire and can make special prices in carload lots.

Write for prices.

NITRATE OF SODA

The most readily available form in which nitrogen can be had. Largely used for forcing vegetables, strawberries, etc., for applying to grass fields after each cutting, producing a strong healthy growth and wonderfully increasing the yield.

Price-Lb. $10 \mathrm{c} ; 25$ tbs. $\$ 1.50$; 50 tbs. $\$ 2.25$; 100 tbs. $\$ 4.50 ; 200$ ibs. $\$ 8.50$; ton $\$ 79.50$.

\section{Inoculating Cultures \\ FOR LEGUMINOUS CROPS}

\section{They Increase Your Crops and Improve Your Soil. MULFORD CULTURES}

Prepared and tested by experts. Each bottle is guaranteed to contain a pure, active, vigorous culture of nitrogen fixing bacteria for the legume indicated on the label. Always specify what crop you want to inoculate, as there is a different strain of bacteria for every legume. Inoculation means a large increase at a small cost.

Price-1 acre size $\$ 1.50$; 5 acre size $\$ 5.00$

We can supply inoculation for the following crops:

Alfalfa, Red Clover, Crimson Clover, Sapling Clover, Sweet Clover, Alsike Clover, Burr Clover, Japan Clover, White Clover, Vetch, Cow Peas, Soy Beans, Velvet Beans.

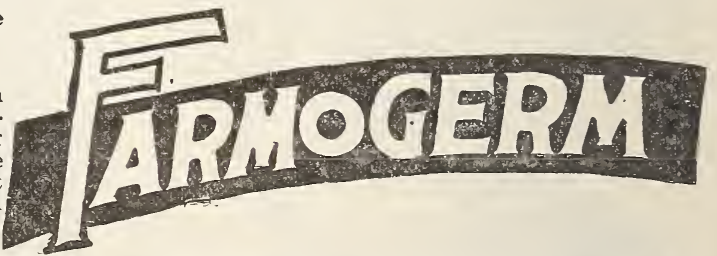

The Standard Seed Inoculant is made pure and is kept pure with the patented Farmogerm stopper the bacterias are kept fresh and active indefinitely. Farmogerm will not fail.

Price-1 acre size $\$ 1.00 ; 3$ acre size $\$ 2.50$; 12 acre size $\$ 9.00$.

Full directions accompany each bottle. 


\section{Orchard Supplies}

Many of the orchards in Western North Carolina have a wonderful crop this season and this shows the effect of proper spraying. Those trees that were not sprayed have produced a crop of wormy, scabby apples that are bringing practically nothing on the market, while the good apples are still bringing a big price. Many of the orchards are in deplorable condition due to the lack of care.

In 1921 the Asheville Seed Company established an orchard supply department to take care of the apple industry in Western North Carolina.

They have continued to develop this department until now they are able to furnish the orchardist with almost anything he needs at a moments notice. It is always our desire to co-operate with our customers in every way possible and we will be glad to suggest at any time the best and cheapest method of controlling the many pests of the orchard.

We are still able to furnish anything for the orchard at the very lowest competitive price, quality considered. We are in a position to furnish at a moments notice, insecticides, sprayers, pruners, and other materials.

Write for our prices in any quantity before buying.

\section{Insecticides and Fungicides}

\section{NO ARTICLE ON THIS PAGE CAN BE MAILED}

\section{Niagara Soluble Sulphur Compound}

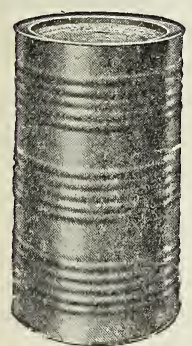

It is a powdered material prepared from a special soda-ash and sulphur, which will dissolve readily in hot and cold water. When used for San Jose Scale it is quick and sure. As a dormant spray, S O L U B L E SULPHUR COMPOUND has no equal.

Besides its insecticidal value, NIAGARA SOLUBLE S U L PHUR COMPOUND has many advantages over the old fashioned lime-sulphur solution. Chief among these are the elimination of $500 \mathrm{ibs}$. of water and package and the consequent saving of freight, the easy and convenient hauling and handling, keeps indefinitely in any climate, no loss from leakage, no freezing or crystallization, no bother returning empty barrels.

Especially for the control of San Jose Scale, we believe Niagara Soluble Sulphur Compound to be the best and most economical spray material on the market.

AMOUNT OF MATERIAL TO USE-For the Dormant Sprays, for the control of such troubles as San Jose Scale, Oyster Shell Bark Louse, etc., use $121 / 2$ pounds of NIAGARA SOLUBLE SULPHUR COMPOUND to 50 gallons of water.

Price-f. o. b. Asheville (fluctuates) -

100 ib. Cans per 100 ibs. $\$ 7.00$.

50 1b. Cans $\$ 4.00$

5 ib. Cans_- $60 \mathrm{c}$.

25 tb. Cans_- 2.25 ;

1 1b. Cans_-20c

The use of Niagara Soluble Sulphur as other than dormant spray is not recommended. For summer spray use Rogers Dry Lime Sulphur and Arsenate of Lead or "Pyrox."

\section{Rogers Dry Lime Sulphur}

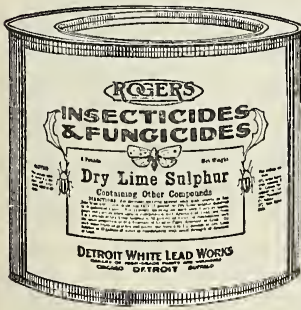

Rogers Dry Lime Sulphur is not a substitute for liquid Lime Sulphur Solution, but is actually the same in dry form. The regular 330 Baume liquid Lime $\mathrm{Sul} \mathrm{ph}$ u $\mathrm{r}$ So:ution is first made to meet all government $r$ e $p$ i r ements, and then by a special process reduced to dry form. To prepare it for spraying it is only necessary to add water. It is useless to explain to growers the many advantages of this excellent material, such as lower costs arrived at by convenience of handling, lower transportation charges, etc. The matter of most importance is the effectiveness. Thru exhaustive tests of both materials under the same conditions, experts representing both manufacturers and the agricultural department have found the result identical and that Dry Lime Sulphur would control the following effectively: San Jose Scale, Oyster Shell Scale, Apple Scab, Pear Scale, Peach Leaf Curl, Brown Rot, Leaf Spot, etc.

Rogers Dry Lime Sulphur for the control of all scales, San Jose, Oyster Shell, etc., when the trees are in a dormant state, is used in the ratio of $10 \mathrm{lbs}$. to $14 \mathrm{lbs}$. to 50 gallons of water.

Use from 3 to 4 tbs. of Rogers Dry Lime Sulphur and $1 \mathrm{lb}$. Dry Arsenate of Lead to 50 gallons of water for control of Apple Scab and Pear Scab, Brown Rot and Leaf Spot are controlled by adding 56 gallons of water to a mixture of $1 \frac{1}{2}$ tbs. Rogers Dry Lime Sulphur and 1 tb. Arsenate of Lead.

Dry Lime Sulphur is highly recommended for all summer sprays in connection with arsenic materials and Black Leaf " 40 " for control of insects and fungus. For more complete information write for our free booklet, "Guide to Successful Spraying." Price of Rogers Dry Lime Sulphur.

200 1b. drums, 11c per 1b.; 25 tb. cans, 14c per tb. $100 \mathrm{lb}$. drums, 12c per tb.; $10 \mathrm{tb}$. cans, 16c per tb. 50 tb. drums, $13 \mathrm{c}$ per lb.; $5 \mathrm{lb}$. cans, 19c per $1 \mathrm{~b}$. 1 tb. cans, 25c per tb.

\section{Bowker's Pyrox}

Thousands of the fruit growers of America will use no other material for killing insects and controlling fungus diseases of $\mathrm{fru}$ i t s, vegetables, grapes, etc. PYROX is made of the purest raw materials and contains a poison in a form which has proved most effective for killing leaf-eating insects. PYROX he'ps to produce perfect fruit and vegetables by protecting plants or trees or vines from insects and fungus diseases. It increases the health and vigor of the foliage-keeps it a rich gree n color throughout The Pyrox Drum. the growing season. This produces the finest quality fruit or vegetable, the kind that brings the highest market price.

Full directions for use of PYROX on apples, pears, quinces, grapes, and vegetable crops will be supplied free. We cannot recommend this material too highly for vegetables and for summer spray of fruit, especially apples.

Write for PYROX catalogue.

Price f. o. b. Asheville-Lb. $40 \mathrm{c} ; 5$ tbs. $\$ 1.50$ 10 lbs. $\$ 2.50 ; 25$ ibs. $\$ 5.75 ; 50$ ibs. $\$ 10.00 ; 100$ lbs. $\$ 18.00 ; 300$ lbs. $\$ 51.00$.

PARA DICHLOROBENZENE - Insecticide for Peach Tree Borer. This material will very quickly rid the peach tree of th:s pest. Use $1 / 2$ ounce to $11 / 2$ ounces to each tree, depending on age.

Express-1 ib. can $35 \mathrm{c} ; 5$ tb. can $\$ 1.55$. 


\section{No article on this page can be mailed except those quoted "Postpaid"}

INSECTICIDES AND FUNGICIDES-Continued

\section{Arsenate of Lead}

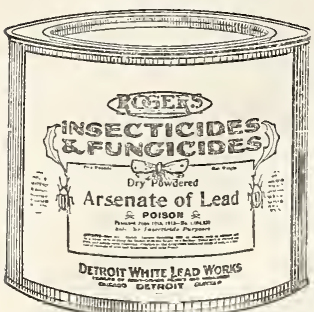

Dry Powdered - The advantages of the use of a dry powdered form if Arsenate of $\mathrm{L}$ e a u over the bulky paste material are many. It is an exceedingly fine divided fluffy powder, which is a greater bulk per given weight than any oth e $r$ powdered Arsenate of Lead manufactured. For this reason it goes into suspension in the spray tank much more readily than the paste lead or any other form of dry Arsenate of Lead. It contains 30 to 33 per cent of Arsenate of Oxide. It is very adhesive and sticks to the leaves and fruit for the longest possible time. This insures the greatest effectiveness at the lowest cost. These advantages make it much preierable to Paris green for destroying leaf-eating insects. Use 1 to 2 tbs. to 50 gallons water for general spraying. Price-1/2 1b. 25c; 1b. $40 \mathrm{c} ; 5$ ibs. $\$ 1.75$ $25 \mathrm{lbs}$. $\$ 7.50 ; 50$ lbs. $\$ 12.00 ; 100$ lbs. $\$ 23.00$.

FISH OIL SOAP AND TOBACCO-(Usually called Whale Oil Soap). An excellent preparation for plants infected by vermin. Also used against fungus diseases and will keep trunks of trees free from borers and other bark destroyers. Destroys the mealy-bug and nearly all lice on indoor plants and scale on palms.

Price, bp express, ib. $25 \mathrm{c}$; postpaid, ib. $35 \mathrm{c}$.

CREO-SUL-A cold water dip, insecticide, disinfectant, deodorizer, antiseptic and detergent. Rapidly fatal to all insect pests which infest domestic animals, but positively harmless to the skin. Heals eruptions and cuts, and promotes new growth of fine hair and wool. A perfect sheep and splendid disinfectant. Invaluable for dog kennels, poultry houses, etc.

Postpaid-Pint $60 \mathrm{c}$; quart $95 \mathrm{c}$

Express-Pint $50 \mathrm{c}$; quart $85 \mathrm{c}$; $1 / 2$ gallon $\$ 1.35$; gallon $\$ 2.25$.

"BLACK LEAF 40"-Destroys such insects as Aphis (Plant Lice), Thrips, Leaf Hoppers. Contains 40 per cent of nicotine. One ounce bottle makes about six gallons; $1 / 2$ ib. tin makes from 40 to 150 gallons spray.

In order to assist the "Black Leaf 40 " to penetrate to and thoroughly wet the insect, it is advisable when spraying with "Black Leaf 40 " alone to add 3 or $4 \mathrm{lbs}$. of dissolved soap to every 100 gallons of spray. When using "Black Leaf 40" in combination with other sprays, do not use soap. Price -1 oz. $35 \mathrm{c}$; $1 / 2$ 1b. tin $\$ 1.25 ; 2$ 1b. tin $\$ 3.50 ; 10$ ib. pkg. $\$ 13.50$, Cannot be mailed

PARIS GREEN-Is very poisonous. Is known to be the most reliable destroyer of all leaf-eating insects, but is almost worthless for destroying what are known as sucking insects If thought desirable to use in solution, which is really the most economical way, from $1 / 4$ to 1 pound will be sufficient to add to 50 gallons of water, or 1 pound to 50 pounds of land plaster, the quantity depending upon the tenderness of the foliage it is to be applied to.

Price-1/4 1b. 20c; $1 / 2$ ib. $30 \mathrm{c}$; 1b. $45 \mathrm{c} ; 2$ ib. pkg. 85c. Cannot be mailed.

BORDEAUX MIXTURE-Endorsed by leading entomologists. Will prevent blight, scab, rust, mildew, black-rot, and other fungus diseases of plants and fruits; also will improve the quality and increase the yield. It should be used on grapes, cucumbers, melons, tomatoes, etc. Potatoes respond generously to thorough spraying. To make a combined Fungicide and Insecticide, add 1 pound of Paris Green or 2 pounds of Arsenate of Lead to 150 gallons of the diluted mixture. 1 ib. of Bordeaux Mixture makes 8 gallons of Spray Mixture.

Postpaid-Lb. 50c; 5 ibs. $\$ 2.00$

Express-Lb. $40 \mathrm{c} ; 5$ ibs. $\$ 1.75 ; 25$ ibs. $\$ 6.25$.

\section{Hammonds' Slug Shot}

A light, composite, fine powder, easily distributed by duster, bellows or in water by spraying. It is thoroughly reliable in killing worms, bugs, fungi, etc., on ca $b$ bage, currants, beans. cucumber, squ a s cauliflower, potatoes, etc., and other vegetable crops. Slug $\mathrm{S}$ h ot keeps garden crops free of diseases and insect pests, invigorates the plants, and increases yields. It is convenient to handle.

Postpaid-Lb. 30c; 5 lbs. 75c; 10 tbs. $\$ 1.40$.

Express-Lb. 25c; 5 tbs. $60 \mathrm{c} ; \quad 10$ ibs. $\$ 1.20$ 50 Ibs. $\$ 5.00 ; 100$ lbs. $\$ 9.50$.

HELLEBORE-For worms, caterpillars, etc. Less poisonous than Paris green and Arsenate of Lead, and safer to use when vegetables and fruits are nearly ripe. Dissolve $1 \mathrm{oz}$. to 2 gals, of water.

Price-Postpaid-1/4 1b. 35c; Express-1/4 ib. 30c.

\section{Copper Sulphate}

Blue Stone or Blue Vitriol-Used for early spraying and in making Bordeaux Mixture and copper solution. Will keep indefinitely.

Express-5 tbs. $70 \mathrm{c} ; 10$ tbs. $\$ 1.30 ; 50$ ibs. $\$ 6.00$ Special prices on large quantities.

90-10 DUSTING MIXTURE-A combination of $90 \%$ pure sulphur and $10 \%$ Arsenate of Lead, for controlling Chewing insects and fungus diseases. For control of apple Scab, Codling Moth, Bud Moth, Case Bearers and similar troubles.

Express-25 1bs. $\$ 2.25 ; 50$ 1bs. $\$ 4.00 ; 100$ 1bs. $\$ 7$.

SULPHUR-For making Lime-Sulphur Spray,

for mildew and plant mites.

Price Postpaid-Lb. $15 \mathrm{c} ; 10$ Ibs. $\$ 1.15$.

Express-Lb. 10c; 5 1bs. $45 \mathrm{c} ; 10$ lbs. $75 \mathrm{c}$; 50 1bs. $\$ 2.50 ; 100$ ibs. $\$ 4.00$.

VERMING0-Insecticide and Disinfectant. It kills by contact bed bugs, roaches, fleas, moths, lice, ants, etc. Use freely in house as disinfectant. Bottle 25c; $1 / 2$ gal. $\$ 1.50$; gal. $\$ 2.75$.

CARBOLA WHITE PAINT-It is recommended for killing lice, mites, fly eggs, etc., and as a preventative of the contagious diseases that effect stock and poultry. Can be applied with brush or sprayer, a disinfectant paint that dries white: use instead of whitewash.

Postpaid-25 ounces $40 \mathrm{c} ; 10$ pounds $\$ 1.45$.

Express-25 ounces $30 \mathrm{c} ; 10$ pounds $\$ 1.30$.

SULPHO TOBACCO SOAP-For a cheap, effective, clean and harmless insecticide for ameteur and professional growers this is unexcelled. Quickly exterminates all insect life on plants and flowers in and out of doors. Unsurpassed for rose bushes. For domestic purposes it rids the house of cockroaches, and is a superior wash for dogs and all animals. Prevents poultry lice.

Price-3 oz. cake, sufficient for $11 / 2$ gals. prepared solution, for $10 \mathrm{c}$; by mail, postpaid, $13 \mathrm{c} ; 8 \mathrm{oz}$. cake, sufficient for 4 gals. prepared solution, for $20 \mathrm{c}$; by mail, postpaid, $28 \mathrm{c}$.

KEROSENE EMULSION-For Sucking Insects. A safe and sure remedy for squash-bugs, plant and bark-lice, San Jose Scale, caterpillars, rosebugs, green-fly, melon and pea louse, and all sucking insects. Add 25 to 50 gallons of water to 1 gallon of emulsion, and it is ready for use. Spray before the blossom buds open and again after the blossoms fall. The second spraying should have Paris green mixed with it to kill leaf-lice and insects. Express-Pint 25c; quart-45c.

Postpaid-Pint 35c; quart-60c. 


\section{Sprayers}

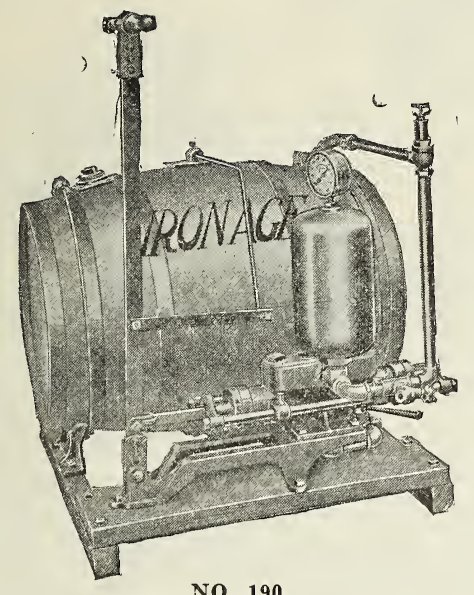

NO. 190

No. 190-Horizontal Barrel Sprayer, with single acting pump. Fifty-gallon capacity; 100 to 125 pounds pressure, with two nozzles; valves, bronze ba'ls which find their seat easily. No corrosion; solution touches brass parts only.

Price- $\$ 40.00$. Hose extra at $\$ 8.00$ per complete lead.

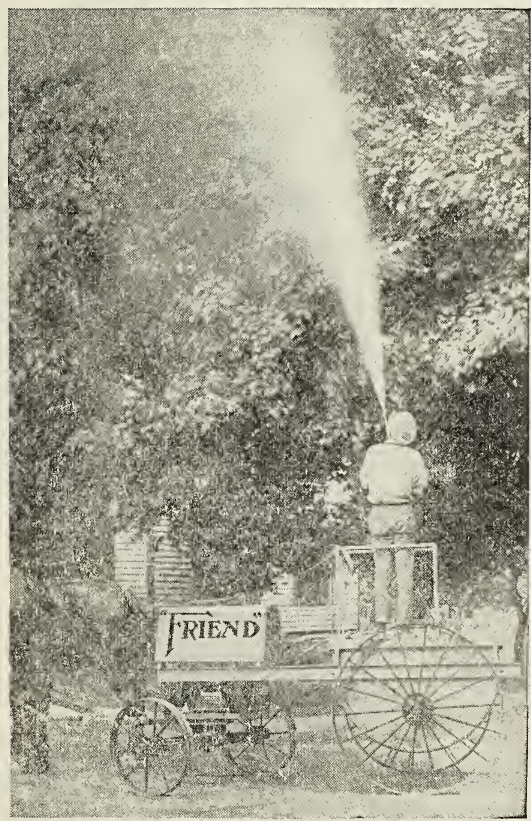

MODEL BX-Friend Power Sprayer.

The most popular, lightweight, medium capacity power sprayer made. This is the original hilly orchard model designed many years ago for mountain work in Virginia, now proven most practical in all sections.

BX motorpump used, 200 gallon tank, direct propeller agitator, low down, short turn, large wheel, easy drawing, "Friend" style; spray-gun equipment. Write for prices.
No. 194-This vertical barrel sprayer is especial ly designed for small orchards and garden work. The outside pump cannot corrode; is easy to repair and more pleasant to handle. Nothing inside except galvanized suction pipe and automatic dasher to keep the solution stirred. The valves are bronze and find their seat easily; the hemp packing has lead core and does not harden. It handles hot or cold solutions, readily maintaining while spraying with 2 nozzles, 100 tbs. pressure.

Price-With bbl., $\$ 25.00$; without bbl., Ask. Leads of Hose, $\$ 8.00$ each extra.

No. 191-Practically same construction as No. 194. It is larger and the valves are so arranged that they can be gotten at from the top. Pressure 100 to $125 \mathrm{fbs}$. with four nozzles.

Price- $\$ 30.00$. Hose at $\$ 8.00$ per complete lead extra.

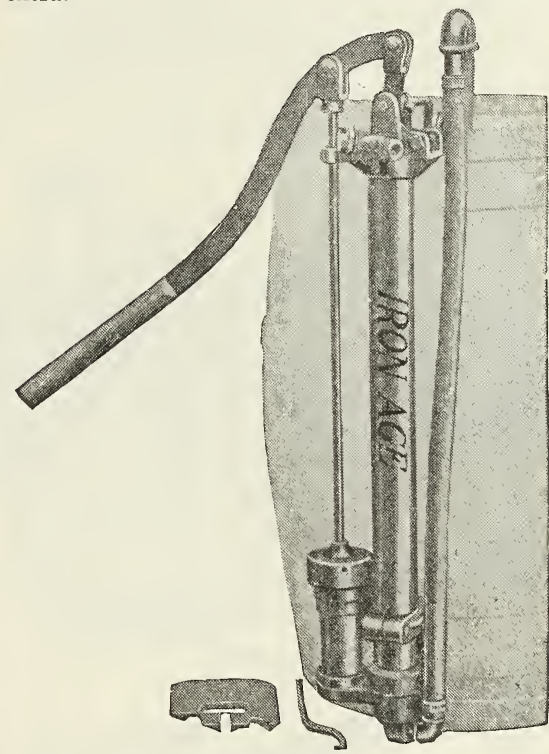

No. 194.

No. 197-Small Barrel Sprayer, 20 gallons capacity, mounted on steel truck, equipped with necessary handles, spray pipe, stop cock, nozzle, sliding hand grip.

Price $\$ 25.00$.

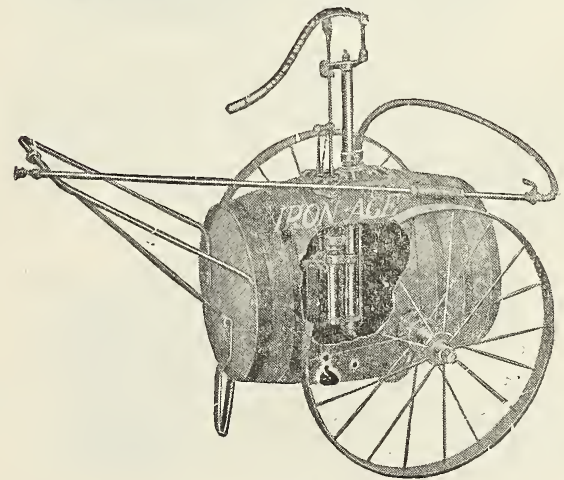

No. 197 


\section{Sprayers -continued}

The Armstrong Standard Spray Pump is simply a very carefully designed and accurately made "squirt-gun" provided with a proper outfit of nozzles. Its simplicity largely accounts for its unusual power.

Its plan of operation is so simple and so different from other types of spraying apparatus. This permits the use of the hose on the suction end instead of on the discharge end. That is why it is possible to use the Armstrong Standard either with a bucket, barrel or knapsack, depending upon the number of trees or the kind of spraying to be done.

For bucket use, a short length of hose is supplied. To use it with barrel or tank for a larger orchard, a longer length of hose up to 25 or 30 feet is desirable. The work of spraying is always done from the ground. No ladder, long extension or raised platform is needed. A large tree can be completely sprayed with ten or a dozen strokes of the pump. The work is done rapidly and with minimum of labor and, by reason of the equal strokes, spraying material is not dissipated.

By different arrangements of the several nozzles regularly supplied, sprays of varying finenessfrom a mist to a straight stream that carries sixty feet-are produced.

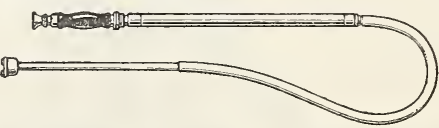

As supplied for spraying from bucket.

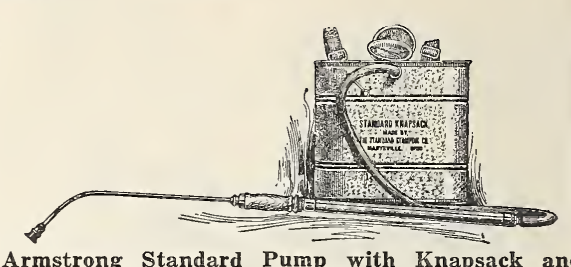
short extension attachments.

For spraying young or scattered trees or truck crops such as potatoes, tobacco and the like, the knapsack and short curved extension are used with the pump. With this equipment, the Armstrong Standard will spray potatoes one row at a time at the rate of an acre an hour or better.

The Armstrong Standard Spray Pump is ideal for spraying liquid insecticides of all kinds, for whitewashing poultry houses and cattle barns, for spraying disinfectants in veterinary use, for washing windows, for washing autos-there is almost a daily use for the Armstrong Standard about the home, farm, garden and orchard.

The Armstrong Standard is made entirely of brass. No leather packings are used and no metal subject to rust or decay. Every Armstrong Standard is warranted for five years. This makes it the most economical spraying device on the maket.

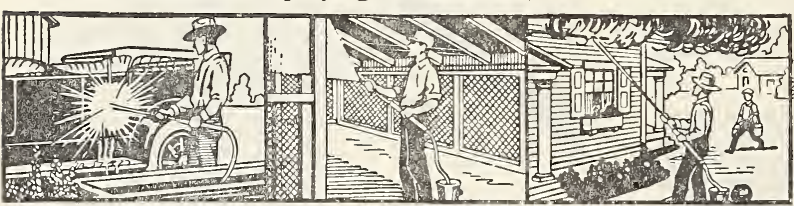

PRICES :

Postp'd Express Knapsack - Potato Extension $1.15 \quad 1.00$ Veterinary Nozzle - $\quad .60 \quad .50$ Complete Outfit - $11.00 \quad 10.25$ Extra Hose, per ft.-- $.221 / 2 \quad .20$

No, 20 GLASS DOUBLE TUBE SPRAYER, "The King of All Sprayers"-Slanting-end air chamber with metal case protecting glass. Painted red. Easy to operate, fill and clean. It is a very durable and practical hand atomizer which throws a fine mist about $2 \frac{1}{2}$ feet. Postpaid- $\$ 1.35$.

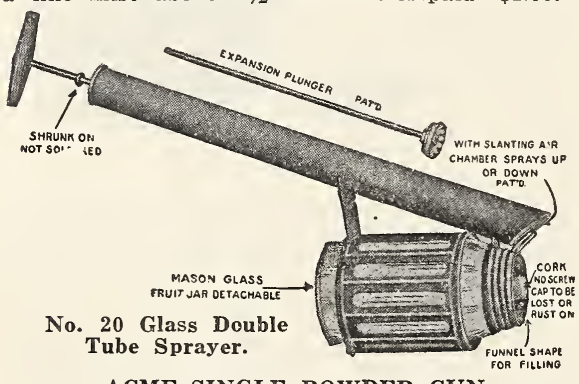

ACME SINGLE POWDER GUN

No. 313-Consists of a tight, valveless bellows, equipped with distributing tube or nozzle, a funnel, a spreader and an elbow for placing the spray on under side of leaves. Handles of convenient length, made of best materials. For spraying powdered insecticides on potatoes, tobacco, garden truck, etc.

Price-Postpaid \$2.15. Express $\$ 2.00$.

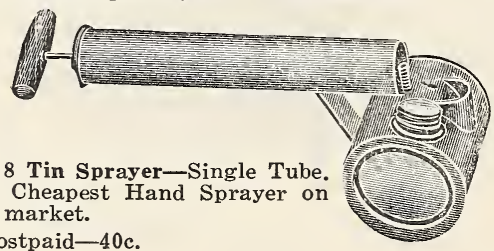

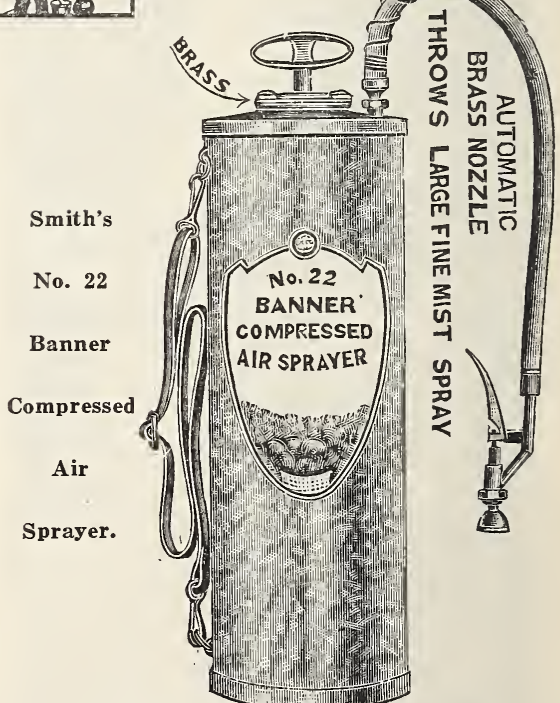

A glance at the illustration and the description will convince you of the superiority of this sprayer. Made to withstand extraordinary wear. No. 22 Banner is adapted for all spraying, and is unsurflower beds. It is also used successfully for whitewashing and spraying disinfectants. The four-gallon tank is made of brass, the pump is all brass and is fitted with golden automatic nozzle which throws a long distance a coarse or fine spray. It is conveniently carried on the shoulder by adjustable straps.

Price, Complete, Brass Tank, $\$ 9.00$. passed for spraying gardens, plants, shrubs, and 


\section{Orchard, Lawn and Garden Tools}

Pruning Saw No. 16 .

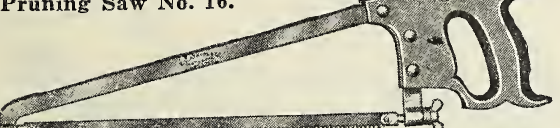

DISSTON PRUNING SAW No. 16-Crucible blued steel blade; polished flat steel frame, slightly tapered; riveted socket; swivel stretcher; adjustable blades; beechwood handle.

Postpaid- $\$ 2.25$. Express- $\$ 2.15$.

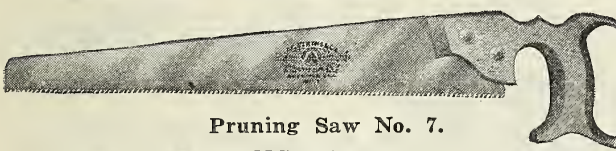

DISSTON PRUNING SAW No. 7-Cast steel blade, applewood handle, polished edges; two brass screws, 18 inches.

Postpaid- $\$ 1.85$. Express $\$ 1.75$.

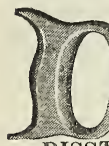

Pruning Saw No. 4.

DISSTON PRUNING SAW No. 4-Duplex, double edge, cast . steel blade, polished. Quick acting teeth on one side and plain teeth on reverse edge; beechwood handle, polished; three brass screws; 16 inches.

Postpaid- $\$ 1.85$. Express- $\$ 1.75$.

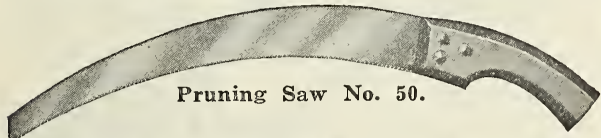

DISSTON PRUNING SAW No. 50-Cresent Shape-Crucible steel blade, polished, carved beechwood handle, brass screws; 14 inches.

Postpaid-\$1.50. Express-\$1.25.

TREE PRUNER No. 32-Select hardwood pole, natural finish; forged steel hook; tempered crucible steel draw cutting knife, blade $43 / 4$ ins. long, insuring ample leverage; steel wire drawing rod; steel lever handle. It does satisfactory pruning from the ground or on outer trunks of large trees.

Express-6 foot extension, $\$ 1.25$; 8 foot extension, $\$ 1.75$.

Tree Pruner No. 32.

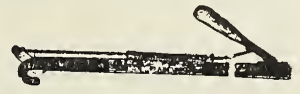

PRUNING SHEAR No, 30-

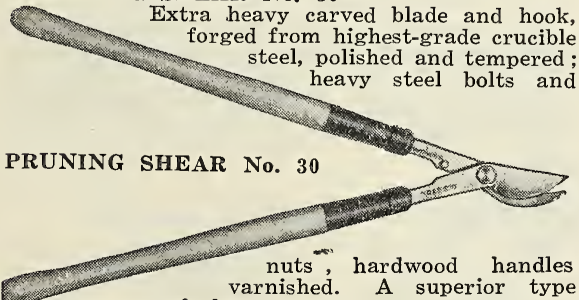
of shear.

20 inch postpaid- $\$ 3.15$. Express- $\$ 3.00$.

24 inch postpaid- 3.40 . Express- 3.25 .

No. 5 Pruner-The ideal cheap pruner.

Postpaid- $\$ 2.15$. Express- $\$ 2.00$.

Pruning Shear No. V13.

Forged tool steel blade 9 inch.

Postpaid- $\$ 1.40$

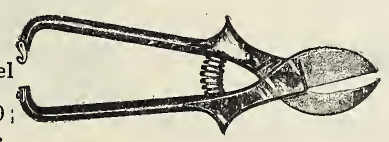

No. 5-CULTIVATOR HOE "PULL EASY"-

Five long, grasping teeth deeply channeled to $\mathrm{g}$ ive maximum strength with extreme lightness. It pulverizes and rakes finely the hardest soil and cul tivates between rows in a superior fashion.

Price, \$1.35.

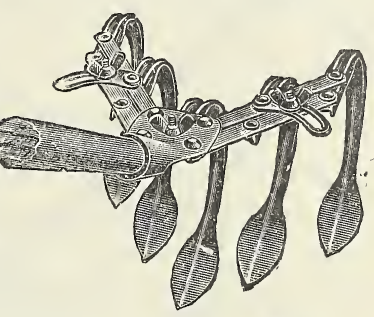

No. 6-"PULL EASY" CUL TIVATOR - Nine strong teeth that make the finest possible seed bed. It can be adjusted for the narrowest rows or to any width up to 18 inches. Steel parts are enameled blue; finest ash handle. Price-\$1.50.

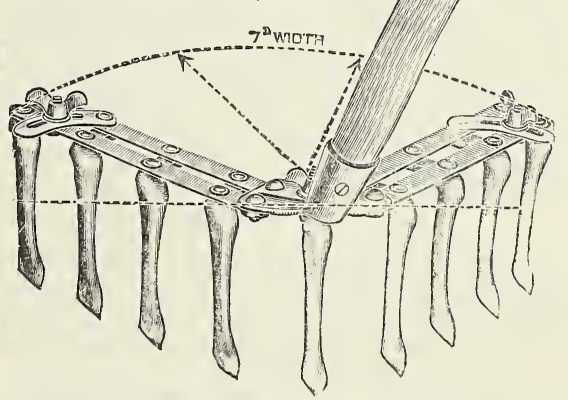

No. 6 "Pull Easy" Cultivator.

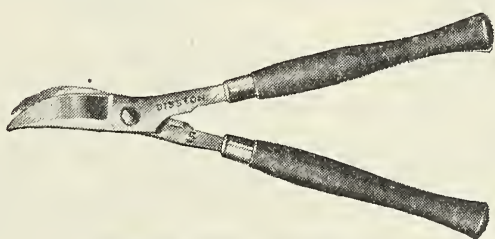

Ladies Hedge Shears No.

Forged Cutlery Steel. 6 inch blades. Postpaid-\$1.65. Express- $\$ 1.50$.

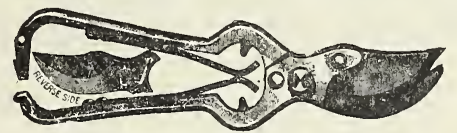

Pruning Shear No. V14

High Grade tempered tool steel blade. Brass spring Ratchet nut.

Postpaid- $\$ 2.10$; Express- $\$ 2.00$.

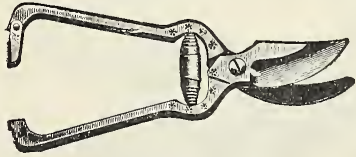

Pruning Shear No. V15

Forged Cutlery steel. Nickel finish.

Postpaid- $\$ 2.60$. Express- $\$ 2.50$.

Pruning Shear No. 313

Tempered tool steel blade. Volute spring. Adjustable ratchet nut. Japanned handles.

Postpaid-\$1.35. Express- $\$ 1.25$.

Pruning Shear No. 314.

Tempered Crucible steel, extra heavy blade. Polished head and handles.

Postpaid- $\$ 3.00 ;$ Express- $\$ 2.85$. 


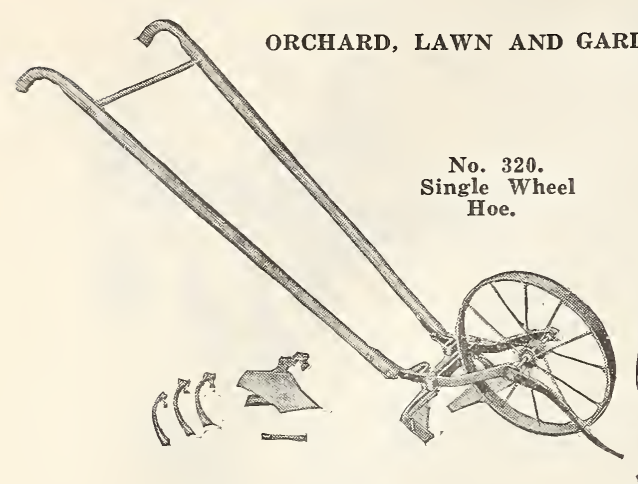

No. 301 .

Double and Single Wheel Hoe.

No. 320-A strong, durable, inexpensive tool that will do all the between-the-row cultivating, furrowing, ridging, weeding, leveling, etc., required in any home garden. Tools include pair side hoes, landside plow, and three steel cultivator teeth, adjustable for close or wide cultivation.

Price- $\$ 8.00$. Complete, with rake, $\$ 8.50$.

Plow No. 50-Is a good low-priced cultivator which has been very popular for several years. The frame is of wrought flat steel, handles adjustable to three different heights. Hand grips 7 inches long; wheel 24 inches in diameter. This is particularly suitable for cultivating rough land. Price $\$ 4.00$.

No. 306-C O M B I N E HILL AND DRILL SEEDER and Double Wheel Hoe-Is the same tool as No. 315 except that it can be made into a double wheel hoe, and has higher frame equipped with landside plow instead of pair of double plows.

Price, 306 complete, $\$ 20.00$.

No. 12-WHEEL PLOW AND CULTIVATOR-

Will plow in all but hard ground, open furrows and cover them; hill growing crops, hoe, rake and cultivate.

Price $\$ 7.00$.

GEM SINGLE-Equipped with five slender cultivator teeth, two sizes of scuffle hoe for work between the rows. Especially for use in hard soil.

Price, $\$ 8.00$.

No. 315-C O M B I N D HILL AND DRILL SEEDER and Single Wheel Hoe-Is a most popular and complete tool, especially planned for all garden work. In a single operation it will open its own furrow, sow in continuous rows or drop in hills, cover the seed with loose soil, pack it with a roller and mark the next row. All vegetables-Asparagus, Beets, Cabbage, Carrots, Onion, Cucumber, Melons, Spinach, Radish, Peas, etc.are planted with No. 315 ; in a most accurate manner insuring an even stand and a well laid out garden. The changes from hill to drill seeder or single wheel hoe for cultivation of vegetables are made with ease and rapidity. All tools shown on the illustration accompany this tool.

Price, 315 complete, $\$ 16.75$.

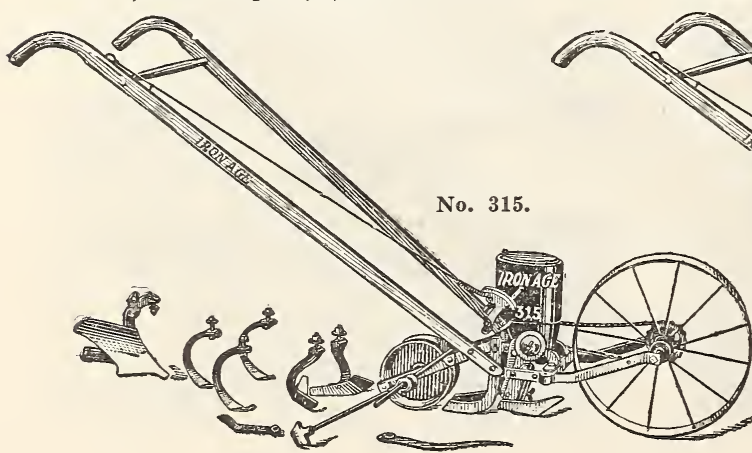

No. 301-D O U B L E AND SINGLE WHEEL HOF_Can be changed from double to single in a minute an extremely valuable feature. You can hoe, cultivate, ridge growing crops, weed level, and pulverize your soil; open furrows, mix fertilizers, cover seed with this excellent tool.

Price, $\$ 12.00$.

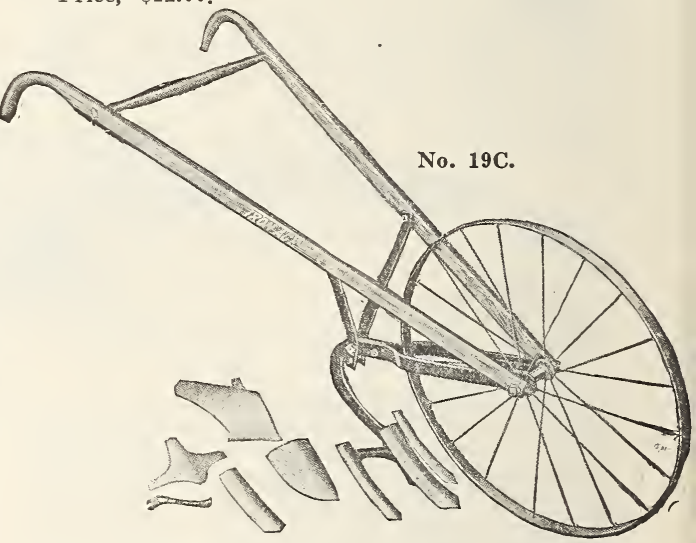

No. 19C-This low-priced, convenient tool easily keeps the ground in perfect cuitivation. Equipped with 24 inch wheel, two sizes single teeth, a scuffle hoe, and set of three teeth on one bracket for hoeing and cultivation between wider rows.

Price, $\$ 6.00$.

No. 316-DRILL AND HILL SEEDER-Is an important tool built especially for those who do not care for a combined tool. It sows in continuous rows or deeply in drills, and is identically the same tool as No. 315 without cultivator attachments. Price, $\$ 15.50$ 
ORCHARD, LAWN AND GARDEN TOOLS-Continued.

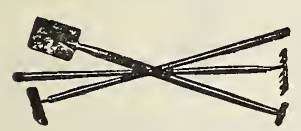

No. 120 FLORAL SET C o m p o s ed of hoe, shovel and rake. The handles are short, making them particularly adapted for working in flower beds or chilNo. 120 Floral Set. dren's gardens.

Postpaid- $\$ 2.25$. Express $\$ 2.00$.

No. 121 FLORAL SET-Consists of heavy shank hoe, 5-tooth iron rake, heavy 6 -inch English Pattern trowel. All finished in gold bronze.

Postpaid $\$ 1.15$. Express $\$ 1.00$.

OAK LEAF ASPARAGUS KNIFE No. 122Special quality tool steel blade, tempered and hardened, hardwood handle; length of blade, 15 inches. Postpaid 55c. Express 50c.

GARDEN HOE No. 127-Cast steel, finely tempered, half polished and painted; $1 \%$ inch solid shank; straight grained white ash handle.

Price, 75c.

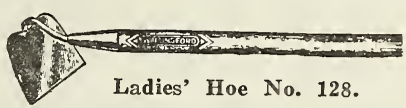

LADIES' HOE No. 128-First quality steel, polished, gold bronzed shank and ferrule, straightgrained white ash handle. A durable hoe of light weight for the garden and flower culture.

Price 65c.

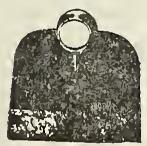

No. 123 UNHANDLED EYE HOE

-Finest quality crucible steel; can be filed or sharpened. 7 -inch blade.

Postpaid-75c. Express-65c.

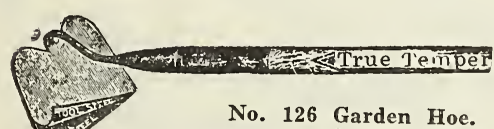

No. 126 GARDEN HOE-Best quality steel blade, polished; fitted traigh grain white ash handle thoroughly seasoned and waxed. Price, $\$ 1.00$.

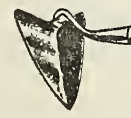

Garden Hoe No. 132.

GARDEN HOE No. 132-Heart shape blade, extra quality and finish; $71 \frac{1}{2}$ inch blade, solid socket; full polished, straight grain ash handle. of particular merit in culture of flowers and Of particular merit in
vegetables. Price, $\$ 1.00$.

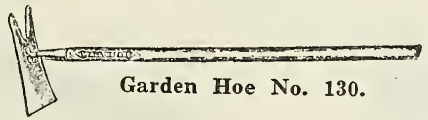

GARDEN HOE No. 130 - First quality steel blades, polished; steel shank, gold bronze finish; straight ash handle. Blades $31 / 2 \times 9$; 4 -ft. handle. Price, 65c.

Garden Weeder No. 131.

GARDEN WEEDER No. 131 - One prong steel blade of superior quality, polished and bronzed; straight white ash handle, capable of pulverizing tough soils; a durable, strong implement. Price, 60c.
GARDEN HOE No. 133-One special piece of crucible steel, half polish; $41 / 2-2$
foot hardwood handle; blade $31 / 2$ in. wide. Used for heavy digging a n d p u l ver izing stiff soils.

Garden Hoe No. $133 . \quad$ Price, 85c.

POTATO HOOK No. 144-145-Broad oval $\mathrm{t}$ in es of re-
markable dura-
bility; straight
shank; plain $\mathrm{t}$ in $\mathrm{s}$ of re-
bilkable dura-
shank; plaint shank; plain straight grain

white ash handle. Offer this excellent tool in two types.

Price-4 Tines, No, 144, $\$ 1.00$.

Price-6 Tines, No. 145, $\$ 1.50$.

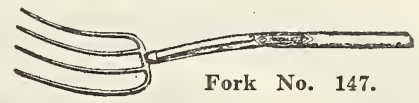

MANURE FORK No. 147-Strap ferrule; gold and blue finish; straight grain white ash handle. We offer only one fork; a superior quality in steel; tines 10 inches long; spread 8 inches wide; $41 / 2$ ft. handle. Price, $\$ 1.50$.

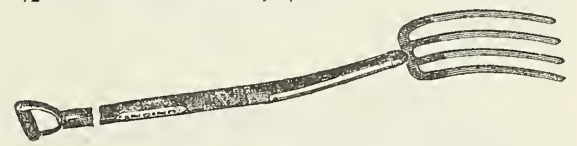

SPADING FORK No. 146-Fine bronze finish; angular steel tines of first quality; straight grained white ash handle. This tool is indispensable to all. gardeners in preparing hotbeds, etc., for small seeds. Price $\$ 1.75$.

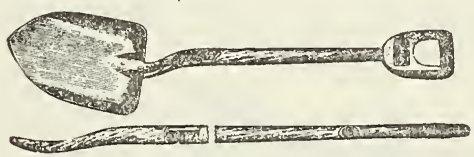

Short Handle Shovel No. 150.

SHORT HANDLE SHOVEL No. 150-Extra cast steel; plain back socket strap; straight grain white ash handle. Used for dirt, coal, manure, etc. Price, $\$ 1.50$. Same design with long handle, $\$ 2.00$.

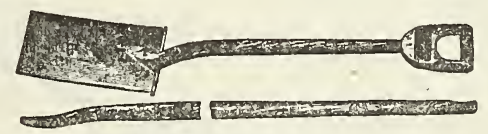

Short Handle Spade No. 149.

SHORT HANDLE SPADE No. 149 - Square point, polished; 12 inch blade length, $71 / 2$ inch width; handle best white ash 27 inches long. Price, $\$ 1.50$.

Same design with long handle. Price, $\$ 2.00$.

LONG HANDLE SPADE No, 148 - Polished black finish; handle $41 / 2 \mathrm{ft}$. long, hardwood finish. Price, $\$ 1.50$.

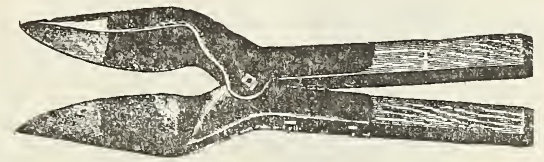

Post Hole Digger No. 151.

POST HOLE DIGGER No. 151-Hardwood handles, round taps, square shoulders, fitted into one solid socket and bolted; one-piece solid steel blades of first quality; blades 9 inches long. Digs 6 inch hole; length over all 57 inches; point of blades polished. Price, $\$ 2.00$. 
ORCHARD, LAWN AND GARDEN TOOLS-Continued.

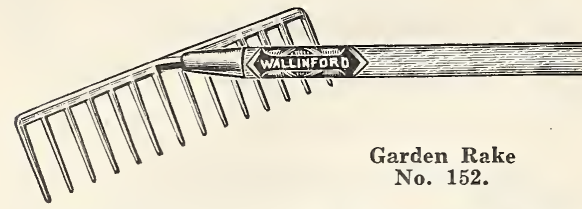

GARDEN RAKE No, 152-The very best quality steel. The teeth are made of polished steel in pairs, so:idly riveted. It is the strongest and most durable rake on the market. Straight grained white ash handle. Price, \$1.25.

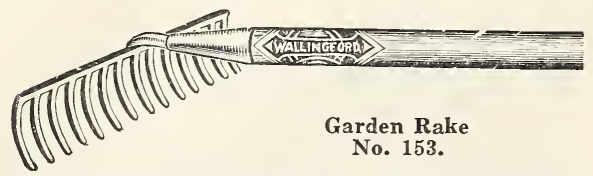

GARDEN RAKE No. 153-Made entirely from best grade of steel, width 5 inch head, teeth and head cut from one solid piece of steel, round steel bow, securely fastened into handle which is good quality white ash. Price $\$ 1.00$.

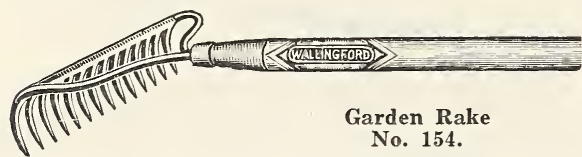

G A R D E N RAKE No. 154-Malleable iron, straight teeth, natural plain ferrule, straight grain ash handle. Price $60 \mathrm{c}$.

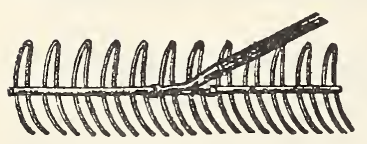

LAWN RAKE No.156-Steel wire teeth rakes have always been particularly suitable for raking lawns. They stir the soil Lawn Rake No. 156. around roots of ging up or disturbing young seedlings of the lawn. Price, 75c.

\section{LAWN RAKE} No.155-Hardwood $\mathrm{h}$ e a d, se c o n d growth hickory teeth, s t r a i g h t

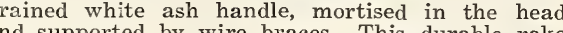
wire braces. This durable rake is excellent for lawns in that it does not destroy or disturb the roots of young grass in raking off leaves or vegetable matter. Price, 65c.

\section{JUNIOR PULL EASY}

Price-No, 17 - 10 inch handle, $65 \mathrm{c}$

Price-No. 8- 4 foot handle, $90 \mathrm{c}$.

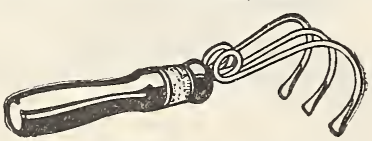

Magic Weeder, No. 51.

MAGIC WEEDER No. 51-Teeth are of spring construction, thus eliminating all jar while using. It is strong in construction, light of weight, and most useful in every respect.

Postpaid-30c. Express-25c.
TRANSPLANTING HOE No.

190-For transplanting long

stem tomatoes and other

plants. Postpaid- $\$ 1.00$.

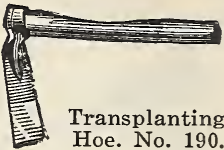

TRANSPLANTING TROWEL No. 191-Onepiece high-grade steel; for transplanting smal plants. Postpaid-35c.

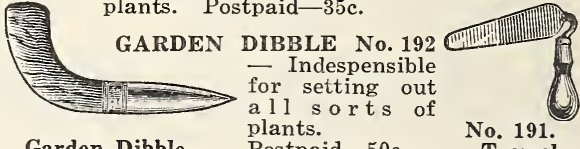

Garden Dibble $\quad$ Plants. $\quad$ No. 191.

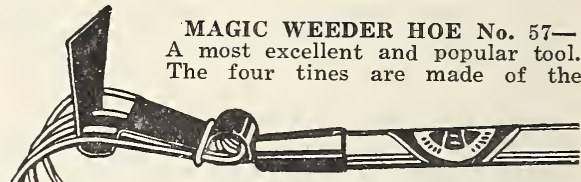

heaviest steel wire; the steel blade is securely fastened and convenient for pulverizing tough soil around roots of plants or for cutting roots. The handle is 4 feet long. Express- $\$ 1.25$.

Magic

Weeder

Hoe MAGIC W E E E R No. 52 - Four 57. bright heavy steel wires are securely bright heavy steel wires are securely
mounted in black ebonized han-
dle; 11/2 inch bright steel blade
fastened securely on back for
cutting large weeds, etc. Length
handle 6 inches. It is famous
the world over
for its usefulMagic Weeder No. 52. Express, 45c.

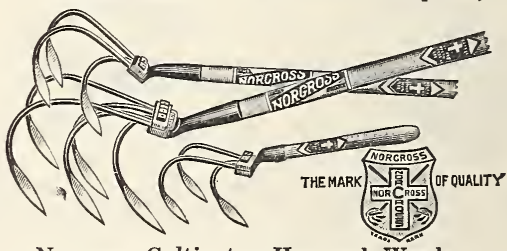

Norcross Cultivator Hoe and Weeder NORCROSS CULTIVATOR HOE AND WEEDER-Will cultivate closer to plants without injuring them than any other type of implement known, leaving the soil level, loose and untrampled. The sharp steel prongs are detachable finely finished, and of great durability. Three sizes and prices.

Express-5-prong 4-foot handle, \$1.00.

Express-3-prong 4-foot handle, .75 .

Postpaid-Weeder, small, 50c.
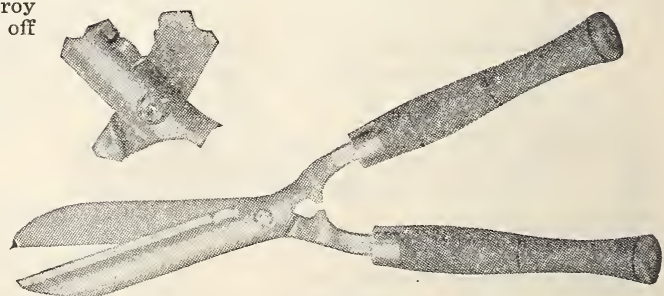

Hedge Shears No. 900

No. 900-Forged crucible steel notched, hammer finish. Hardwod handles. Blade 9 inches.

Postpaid-\$2.75. Express-\$2.50. 
ORCHARD, LAWN AND GARDEN TOOLS-Continued.

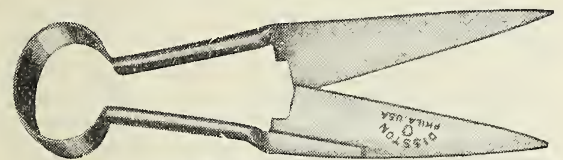

GRASS SHEARS No. 158 - Straight blades, shanks and spring, stamped and forged from one piece of steel; shanks and cutting edges are polished.

Postpaid-\$1.00. Express-90c.

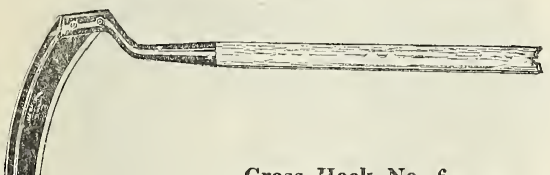

Grass Hook No. 6.

Long handle 43 inches. Grass hook 12 inches-Crucible blade, tempered and ground.

Express-\$1.25.

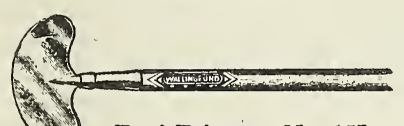

TURF TRIMMER No. 157Polished steel

Turf Trimmer No. 157. blade of excelle $n$ t quality,

bronze finish, solid shank, $4 \mathrm{ft}$. white ash handle. This tool trims smoothly all sods of banks and is a great labor saver. Price, $\$ 1.35$.

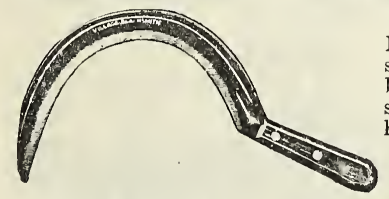

GRASS HOOK No. 4 - Cutlery steel, tempered blade, thin and sharpe $\mathrm{r}$ ive te d handle.

Postpaid, 60c. . GRASS HOOK No. 3-Patent offset handle, tempered ground forged cutlery steel.

Postpaid, $\$ 1.10$.

Express, $\$ 1.00$.
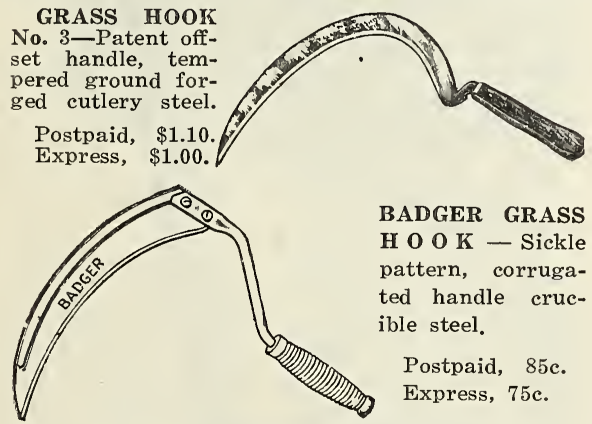

BADGER GRASS H O O K - Sickle pattern, corrugated handle crucible steel.

Postpaid, 85c.

Express, 75c.

DANDELION DIGGER No. 1.

Steel knife. Used for lifting dandelions without injuring lawn.

Postpaid, 55c. Express, 50c.

\section{WATERING POTS}

Galvanized

By Express.

10 Qt. - -

8 Qt. - - - - 1.50

6 Qt. - - -

4 Qt. ------ 1.00 Japanned.

4 Qt.

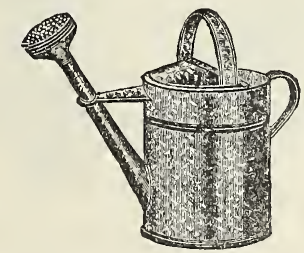

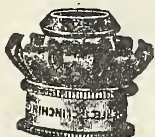

HOSE COUP. LINGS No. 167

-Postpaid, 35c each.

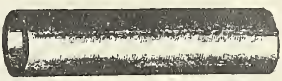

Garden or Lawn Hose No. 169. GARDEN or LAWN HOSE No. 169-Best offer of best quality hose; high-grade cotton duck; black cover; withstands high pressure. It is an excellent hose for all general uses.

Price per foot, 15c, by express.
GRASS CATCHER No. 151-A metal bottom catcher made of finest quality, extra heavy white duck with heavy galvanized wire frame and adjustable steel hooks; non-skid bottom prevents grass from slipping forward.

Price, $\$ 1.75$.

LAWN SPRINKLER No. 163-Made entirely of sheet brass which does not corrode; hollow ring

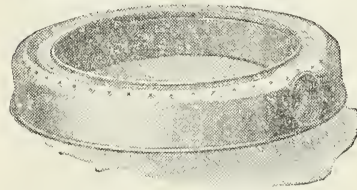

w it h perforated top ; light, strong and durable; throws a uniform and even spray over a surface of 30 to 40 feet.

Postpaid, $\$ 1.10$. Express, $\$ 1.00$.

LAWN SPRINKLER No. 164-Brass sheet iron highly polished and lacquered. Top perforated for throwing continuous and even spray. A durable low - priced sprinkler.

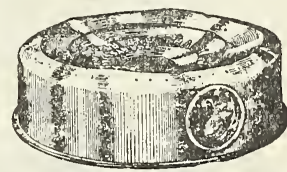

Postpaid, 60c. Express, 50c.

LAWN SPRINKLER No. 166-Cast iron stem and hose; brass arms and head; arms polished, stem enameled red. It revolves so easily that even low pressure keeps the marvelous spray falling softly like gentle rain on lawn or garden.

Postpaid-\$3.25.

Express- $\$ 3.00$.
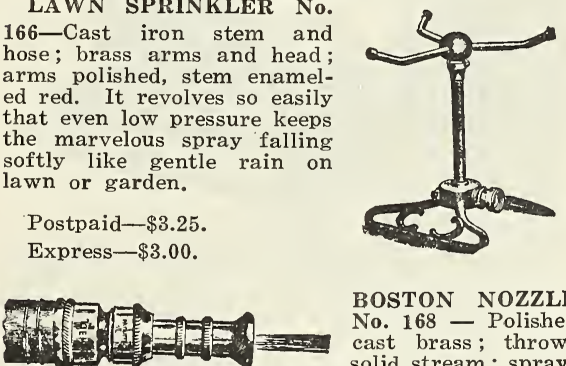

BOSTON NOZZLE No. 168 - Polished cast brass; throws solid stream; sprayer can be shut off entirely. Will fit couplings of both $1 / 2$ and $3 / 4$ inch hose. Postpaid, 85c. Express, 75c.

HOSE REEL No. 165 - The very best hose reel on the market for lawn or garden. It is a tubular all metal reel. Simple in construction, easily manipulated and exceptionally durable. The corrugated iron drum is 9 inches in diameter; the wheels are $21 \frac{1}{2}$ inches in diameter; capacity 100 feet of hose. Do not wear the hose out dragging around on the ground. The reel keeps it clean and makes the best of care simple. Price, $\$ 5.00$. 
ORCHARD, LAWN AND GARDEN TOOLS-Continued.
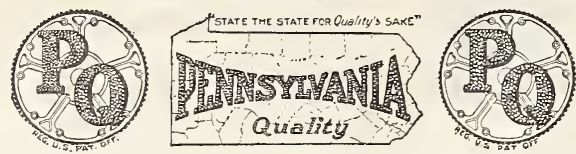

Pennsylvania Lawn Mowers are the result of over a third of a century of scientific study, combined with practical knowledge of many and varied conditions under which they may be used. It is known everywhere as the lawn mower of quality. Let this quality solve the ever preplexing troubles of a smooth running and even cutting machine.

Pennsylvania Junior, Ball Bearing

Blades-Five crucible tool steel, oil hardened and water tempered. Gears-A triple set on each side. Wheel Base-Extra long, cuts smoothly over uneven ground. Wheels 10 inches.. Open spokes. Bottom Knife-Raised edge of tempered, crucible tool steel. Height of Cut $-1 / 4$ to 1 5-16 inch. Will cut grass 6 inches high. Handle-Hard wood; iron braces on cross-bar.

The Pennsylvania Jr., has all the good points of the Standard Pennsylvania, with the addition of some features that make it the most perfect grass cutter in the world. Its self-sharpening features alone will make it worth its cost to the user, as it will save this expense until the blades are worn out-in average use a dozen years or more.

Price-17 inch $\$ 28.50 ; 19$ inch $\$ 32.50$.

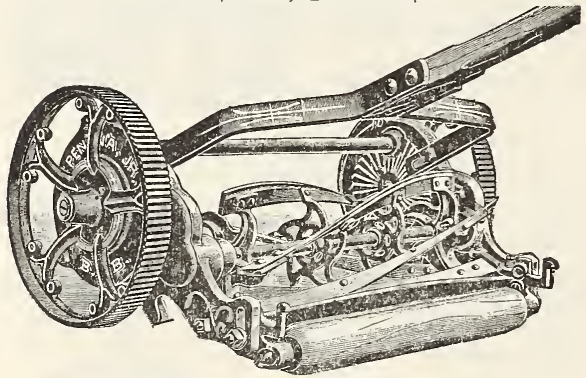

Pennsylvania Junior

GREAT AMERICAN BALL BEARING

Blades-Five crucible tool steel, oil hardened and water tempered. Gears-Double; one in each drive wheel; cone and cups, hardened tool steel; extra large balls of highest quality. Wheels-10 inches; solid center, protecting gears; six spokes. Parts-Malleable and cast, accurately machined to insure noiseless service. Bottom Knife-selfsharpening; raised edge; crucible tool steel, insuring long service. Height of Cut-1/2 to $1 \frac{1 / 2}{\text { ins. }}$ will cut grass 6 ins. high. Handle-Hard wood; iron braces on cross-bar.

The Great American Ball Bearing is the best all-around mower of its type in the world. The perfectly-fitting ball cups and cones insure an easy running machine.

15 inch, $\$ 20.00 ; 17$ inch, $\$ 22.50 ; 19$ inch, $\$ 25.00$.

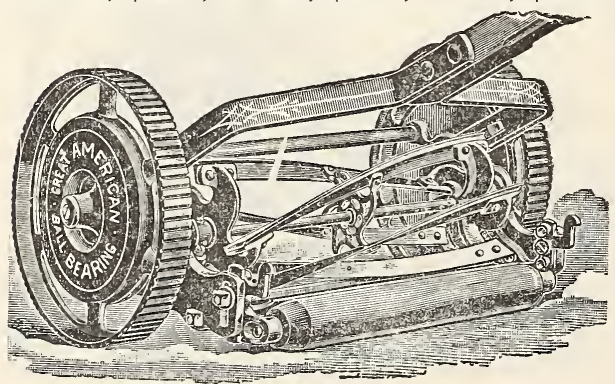

The Great American-Ball-Bearing.
Delta Ball Bearing

Blades-Four-crucible tool steel, hardened and tempered. Gears-Internal. One in each wheel. Bearings-Full "Pennsylvania Quality" bearings. Wheels-8 inches. Spoked rim. Parts-Malleable and cast. Accurately machined to insure noiseless service. Bottom Knife-Enos patent. Selfsharpening. Tempered spring steel. Height of Cut- $1 / 2$ to $11 / 4$ inches. Will cut 5 -inch grass. Handle-Hard wood.

Price-16 inch, $\$ 12.50$.

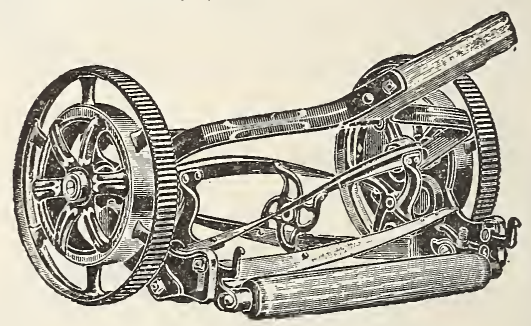

ORCHID BALL BEARING

Blades-Four crucible tool steel, hardened and tempered. -Gears-Internal, one in each wheel, covered by dust-proof cap. Bearings-Balls, cups and cones identical with those used on Pennsylvania Junior and our other high priced machines. Wheels-10 inch diameter; open center or spider pattern; reinforced rims. Parts-Malleable and cast; machined to fit, insuring noiseless smooth cutting. Bottom Knife-Spring steel, hardened and tempered; the cast bar holding the knife is fitted to side plates, permitting accurate set screw adjustment. Height of Cut $-1 / 2$ to $1 \frac{1}{2}$ inch; will cut grass 6 inches high. Handle-Hard wood.

Price-16 inch, $\$ 16.00$ each.

\section{Electra}

Blades-Crucible tool steel, hardened and tempered. Gears-Internal. One in each wheel. Bearings-Parallel. Adjustable to take up wear. Wheels - 8 inch low wheel or 9-inch high wheel. Spoked rim. Parts-Malleable and cast, accurately machined to insure noiseless service. Bottom Knife-Spring steel. Hardened and tempered. Enos patent. Height of Cut- $1 / 2$ to $1 \frac{1 / 2}{2}$ inches. Will cut grass 5 inches high. Handle-Hard wood.

Price-14 inch, $\$ 10.00$.

PENNSYLVANIA

UNDERCUT B. B

The unique construction of the undercut trimmer permits cutting, not only close up to a wall fence, tree, etc., but it will get the grass under a f $n$ ce or rock-cut base of tomb stones, house foundations and other places hitherto out of reach of anything but hand shears.

The slanting side plate and conical cylinder make it possible to cut all grass beft by the regular style of lawn mower. 91/2-inch Drive wheel.Four-blade cylinder. Widt of cut, $5 \frac{1}{2}$ ins.

Price- $\$ 12.00$

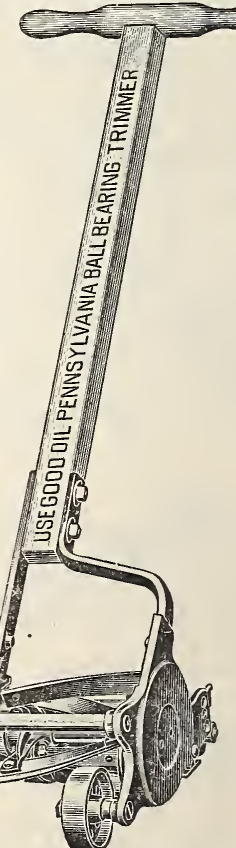

New Westfield

8 inch Wheel. 3 Knife.

Price-12 inch $\$ 8.50$. 
ORCHARD, LAWN AND GARDEN TOOLS-Con. LAWN ROLLERS

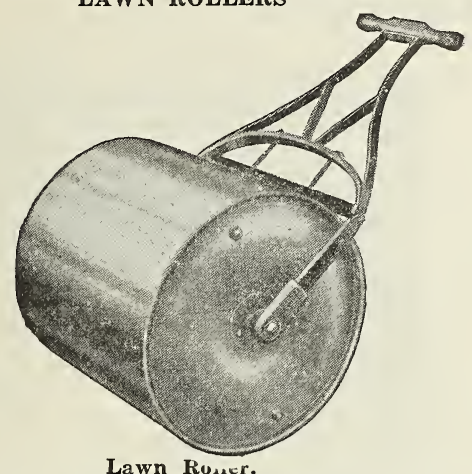

Lawn Ruscr.

Our water ballast rollers have high carbon steel axles and roller bearings. The electrically welded steel drum may be filled with water or sand to increase the weight. It is the most satisfactory roller on the market. It is durable and strong; can be made any weight up to capacity of individual roller, and is easy and convenient to handle.

No. $170-\$ 18.50$. Empty, 50 tbs. Filled, $150 \mathrm{lbs}$. No. $171-\$ 22.25$. Empty, 85 tbs. Filled, 300 tbs. No. 172-\$25.75. Empty, 110 tbs. Filled, 500 tbs. Filled with sand, weights are 227 tbs., 450 ibs. and 750 lbs.

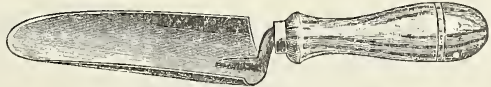

Garden Trowel No. T 20.

Rolled steel, riveted blade Postpaid-40c; Express 35c.

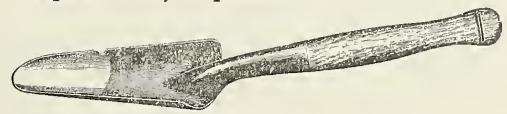

Garden Trowel No. T 15.

One piece crucible steel, blade and socket. Postpaid-60c; Express 50c.

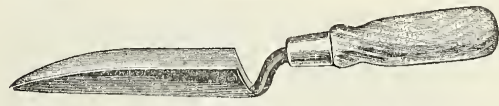

Garden Trowel No. T 10

Six inch heavy crucible steel, forged one piece Hardwood Handle.

Postpaid-90c; Express 80c.

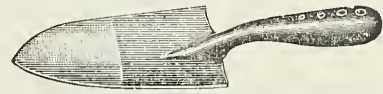

Garden Trowel No. 80

One piece pressed steel. Ground and polished points.

Postpaid-30c; Express 25c.

\section{Buckeye Brooders write for Catalogue.}

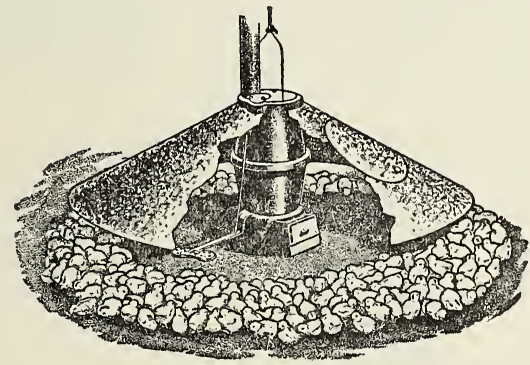

\section{Standard Colony Brooder}

\section{Coal Burner.}

Grows Three Chicks Where One Grew Before.

Brooder that provides constant temperature, supply of pure, fresh air, plenty of exercise and no possible chance for crowding, every essential for the welfare of growing chicks-with such automatic regularity that all unfavorable conditions are eliminated. It requires little attention, is inexpensive to operate, and raises more chicks and stronger chicks than any other brooder.

No. 18- 500 Chicks, $\$ 21.50$.

No. 19-1,000 Chicks, 26.50.

No. 25-1,200 Chicks, 30.00 .

THE NEW BLUE FLAME BROODER

Sold under 30 days money back guarantee. Burns oil and it is easy and convenient to operate. Gives at all times uniform heat. As there are no curtains on these brooders, there is always an abundant supply of pure air, which baby chicks need as much as heat.

No. 27 Blue Flame 200 chicks, $\$ 17.50$.

No. 28 Blue Flame 350 chicks, 20.00 .

No. 29 Blue Flame 500 chicks, 22.50 .

\section{Buckeye \\ Portable}

\section{Brooders}

Oil Burner.

Broods Like Coal Burner.

Durable, Inexpensive, No Water, Pure Air.

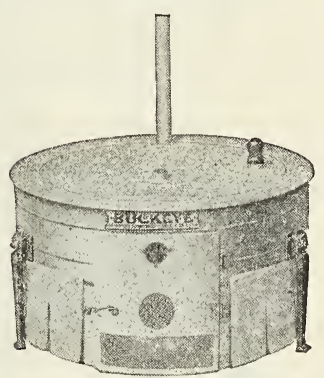

This excellent Brooder is especially constructed for the small raiser. It is made of the very best quality metal, inexpensive to operate, and gives absolutely the most satisfactory results in every way. The operation is simple and effective, there being at all times an adequate supply of fresh air-the greatest virtue any brooder can have.

No. 20-Metal Brooder, 60 Chicks, \$11.75.

No. 21-Metal Brooder, 100 Chicks, 15.50.

No. 22-Metal Brooder, 150 Chicks, 19.00.

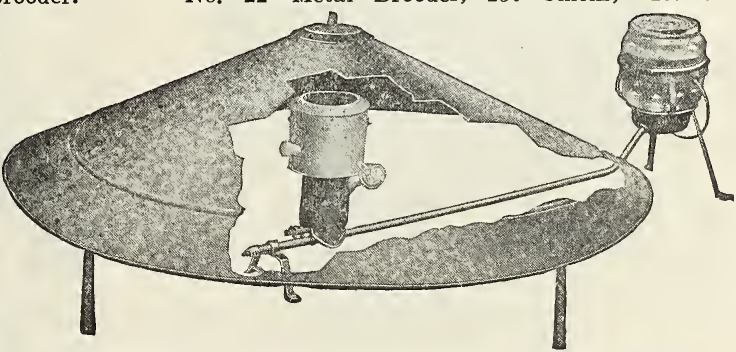

BUCKEYE BLUE-FLAME “COLONY" BROODERS 


\section{Buckeye Incubators, The Perfect Hatchers}

We are exclusive agents in Western North Carolina for the famous Buckeye Incubators and Brooders. Years of experience in the poultry supply business have convinced us that these are the most efficient hatchers on the market.

The unprecedented success which has followed the Buckeye for thirty years is primarily due to the invention of the Buckeye water system. With out this wonderful system of hot water heating, that perfect balance between the temperature, moisture and ventilation, which is so necessary to successful incubation, would be a physical impossibility.

Too much importance cannot be attached to keeping impure gases and fumes out of an incubator. The hot water of the Buckeye is heated on the outside, eliminating all damage to eggs from fumes and gases. It is this feature, together with the perfect temperature maintained by the Buckeye, that makes it possible for it to hatch more chicks and better chicks than any other incubator.

Catalogue of Incubators, Brooders, and Spare Parts sent on request.
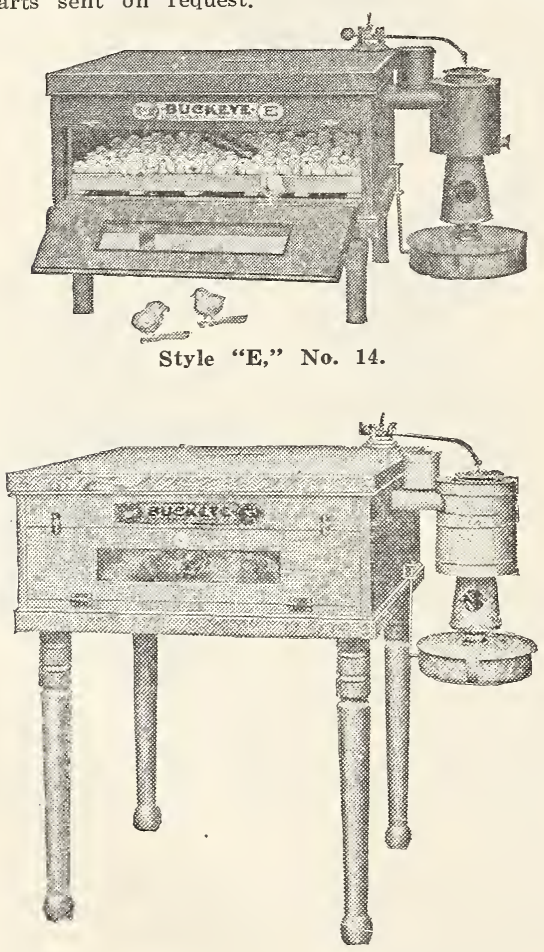

Style “E," No. 17.

Prices of Style "E" Incubators

No. 14- 65 Egg Capacity _-_-_-_-_-_ $\$ 16.50$

No. 16-120 Eog Capacity -

No. 17-210 Egg Capacity -

Style " $E$ " Incubators are low in price and at the same time giving universal satisfaction. Hundreds of poultrymen in Western North Carolina are ready to vouch for this superior low-price incubator.

Incubator Thermometers

Price- $\$ 1.25$ postpaid.

Brooder Thermometers

Price- $\$ 1.25$ postpaid.

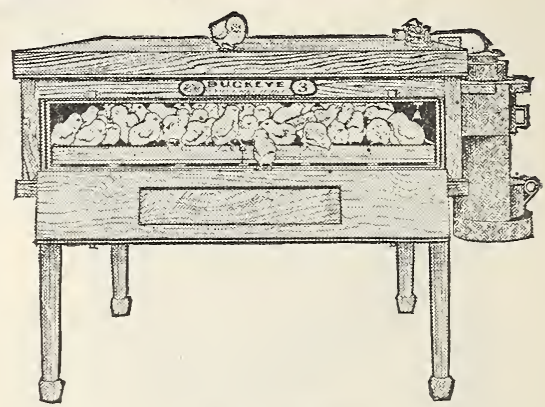

No. 3 Standard.

\section{BUCKEYE STANDARD INCUBATORS}

Buckeye "Standard" Incubators are equipped with every desirable device that could possibly add to the efficiency of an incubator. Only the best of materials are used and each machine is inspected by the National Board of Insurance Underwriters before they leave the factory.

It requires no artificial moisture, will operate satisfactorily in any climate, and requires no attention to the regulator from the time a hatch is started until it is finished.

It is not necessary to have any previous experience to operate a Buckeye. The entire Buckeye system is so simple that a boy or girl can operate it as satisfactorily as an experienced operator.

Buckeye Standard Incubators are equipped with every desirable device that can possible be added to an incubator. The big breeders say that there is nothing left undone-nothing to be wished for in the "Standard." Each machine carries Underwriter's Guarantee.

Prices Buckeye Standard Incubators

\begin{tabular}{|c|c|c|}
\hline o. $1-120$ & Egg & $\ldots$ \\
\hline & Egg & \\
\hline $3-25$ & Egg Car & 57.75 \\
\hline $4-3$ & Egg Capacity & 68.00 \\
\hline $5-60$ & Egg Capacity & ------- \\
\hline
\end{tabular}

\section{BUCKEYE GUARANTEE}

Buckeye Incubators are guaranteed to hatch every hatchable egg, and we further guarantee the perfect working of all its mechanical parts. Should the incubator fail to fulfill our guarantee in any particular, it may be returned to us at our expense (via freight) any time within 40 days after its receipt, and we will send the purchaser a new incubator in exchange.

\section{SMOKE PIPE}

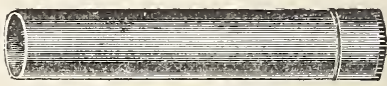

No. 114 Smoke Pipe-Diameter 3 in. Black sheet iron, in 2 foot lengths.

Price per length-15c.

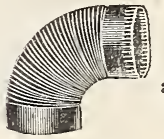

\section{CORRUGATED ELBOWS}

No, 115-Corrugated Elbows-Diameter 3 inches, Black.

Price each, 15c.

CHIMNEY COLLARS FOR BROODER STOVES

No. 117-Chimney Collars. Size $6 \times 3$ inches.

Price each, 10c. 


\section{Poultry Supplies}

Standard Feeders, Watering Fountains, Shell Boxes, etc., are indispensable to all poultry raisers. These appliances not only pay for themselves by saving a large percentage of the feed, but at the same time keep the feed and water free from dirt. This sanitary feature alone brings large returns by keeping the flock in healthy condition.

\section{O E'S IMPROVED}

WALL FOUNTAINS-

Made of heavy galvanized iron, in three sizes. The covered outlet keeps out dust and dirt, and the outlet is further protected by a removable plate which prevents any floating rubbish from being drawn into the reservoir.

No. 97-2 Qts. postpaid. $\$ 1.00$. Express, $\$ .85$ No. 98-1 Gal. postpaid, $\$ 1.15$ Express, $\$ 1.00$ No. $99-2$ Gal. postpaid, $\$ 1.50$ Frnress, $\$ 1.35$

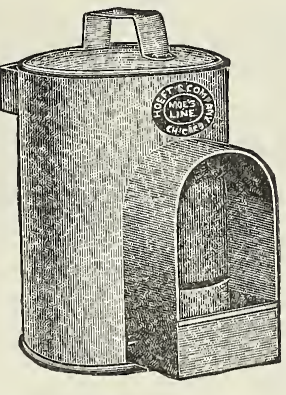

DRY MASH HOPPERS

The curved bottom of the Hopper keeps the feed within easy reach of the birds. The gradual enlargement from top to bottom prevents clogging. The wire grid and wires running from the flange through the wire grid prevents any chance of the fowls throwing out or wasting feed. The sloping cover prevents the birds from roosting on the Hopper, and when both covers are closed, it is rat and mouse proof. A trial will convince you that this is a feeder of superior merit. Dry Mash Hopper. Galvanized iron.

No. $35-81 / 2$ inches wide, $\$ 1.50$. Postpaid, $\$ 1.80$. No. $36-12$ inches wide, $\$ 2.00$. Postpaid, $\$ 2.30$. No. 37-24 inches wide, $\$ 2.80$. Postpaid, $\$ 3.15$. MAGAZINE CHICK FEEDER AND WATERER

No. 18 - A new round chick feeder with a magazine or container to hold a good quantity of feed. The upper magazine is fitted to the feeder top with a spiral thread so it can be adjusted up or down to feed the various kinds of grain. It can also be used as a drinking fountain as the magazine is water and air tight.

Each, 60.

Postpaid, 75c.

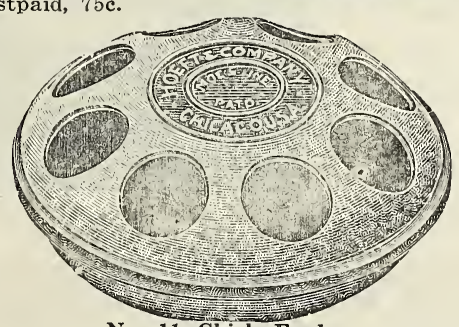

No. 11 Chick Feeder.

Pure food for the baby chicks. A great feed saver, as the little chicks cannot get into it and contaminate the feed. Cannot be upset. Can also be used for water and milk. It is practical, and made from first-quality galvanized iron.

No. 11-6 in. diameter, 15c. Postpaid, 25c. No. $12-81 / 4$ in. diameter, 25c. Postpaid, 35c.

\section{MOE'S GRIT AND SHELL BOXES}

Grit, shell, and charcoal are recognized an essential part of the diet insuring healthy fowls. They cannot be more economically supplied than in our grit and shell boxes. Prices:

No. 90-4 Compartment, $\$ 1.25$. Postpaid, $\$ 1.40$. No. $9-3$ Compartment, .90 . Postpaid, 1.05 . No. 45-? Cnmnortment, .40 . Postpaid, .50 .

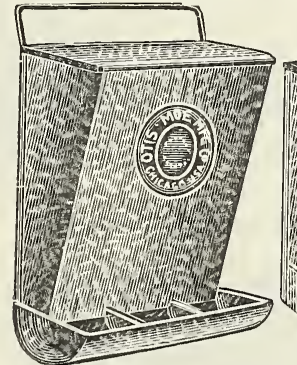

No. 9-Three Comparment

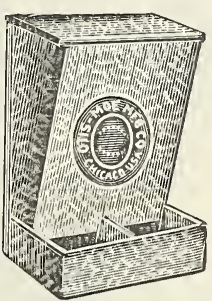

No. 45-Two Comparment

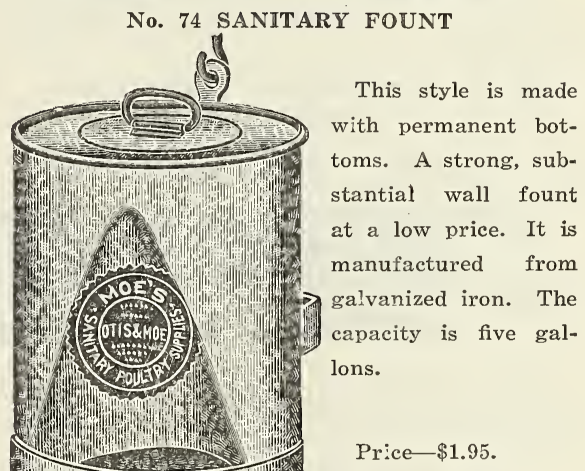

Postpaid- $\$ 2.25$.

Sanitary Fount No. 74.

SANITARY STONE FOUNT

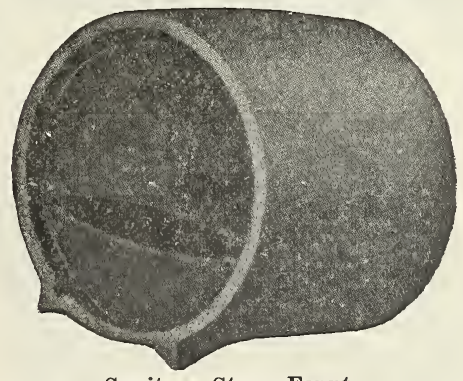

Sanitary Stone Fount.

These fountains are made of fine quality stoneware. They are sanitary, easily cleaned, and convenient to handle.

Prices of Sanitary Stone Fount:

No. 21-1 gal. size, \$.85. Postpaid, $\$ 1.00$.

No. $22-1 \frac{1}{2}$ gal. size, 1.00. Postpaid, 1.15 .

No. $23-2$ gal. size, 1.25. Postpaid, 1.45 . 
POULTRY SUPPLIES-Continued.

NORWICH CHICK FEEDER-Keeps the feed clean and free from pollution. Chicks can feed easily, but cannot get in it.

With rain top, Postpaid, \$1.15; Express, $\$ 1.00$.

Without rain top, Postpaid, 90c; Express, 75c.

\section{No. 10 Poultry Fount}

Galvanized Ware. Does not rust. Made to fit any Mason Jar. Can be used also as Feeder.

Price, Each, 20c; Postpaid, 25c.

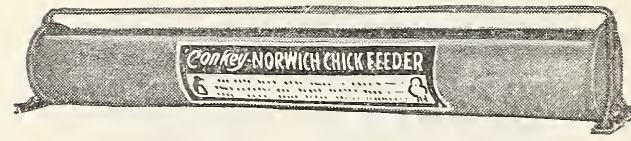

Sanitary Feeding Troughs

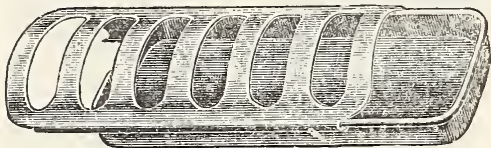

Suitable for dry feed, wet mash, or water. For grown fowls. No sharp or rough edges to injure the chicks.

No. 21-12 in. long, 40c. Postpaid, 50c. No. 22-18 in. long, 60c. Postpaid, 70c.

\section{Single Feeding Troughs}

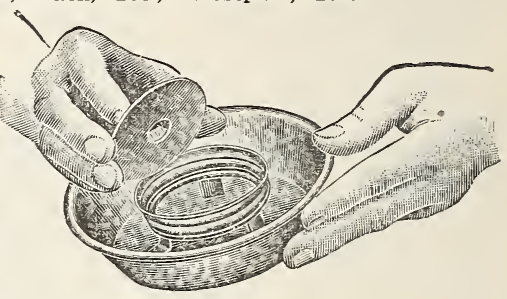

\section{Pigeon Feeders}

Pigeons are particular and fastidious feeders with a strong tendency to scatter and waste feed. Moe's round Pigeon feeder was especially designed to overcome this. Made of heavy galvanized iron, with feeding holes properly spaced all around the hopper. The hopper has a slanting bottom leading through large tube to the feeding bottom. This feeding trough or bottom is also made on a slant causing the birds to reach for the food and prevents them from billing the feed out and wasting it.

No. 105 capacity 3 qts. $\$ 1.00$ each; Postpaid $\$ 1.15$. No. 106 capacity 6 qts. 1.50 each; Postpaid 1.75.

\section{0}

Made of best quality galvanized iron, accurately stamped with dies. No sharp or rough edges to injure the chicks. Sliding Top. Easily cleaned. Can be hung on the wall.

No. 55-12 in. long, 35c; Postpaid, 45c.

No, 56-18 in. long, 40c; Postpaid, 50c.

\section{Double Feeding Troughs}

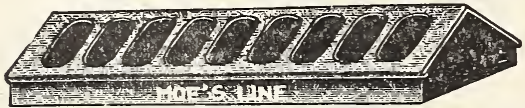

Made same as single feeding troughs. With center partition. Can be used for two kinds of feed.

No. 58-12 in. long, 45c; Postpaid, 55c. No. 59-18 in. long, 60c; Postpaid, 70c.

Aluminum Feeding Troughs

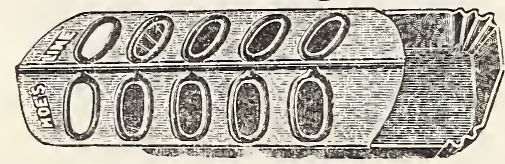

Buttermilk Feeding Troughs, made of pure aluminum, which is not affected by the acids of milk and similar feeds.

No. $69-10$ in. long, 50c; Postpaid, 60c. STAR FOUNTAIN

Made to fit any Mason jar. (We do not furnish the glass jars.) Made of a single piece of nonrusting metal. Can be used for feed as well as water. Price, 15c each. Postpaid, 20c.

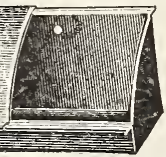

FOUNTAIN

HEATER

Can be used with all styles of fountains, and effectively prevents water from freezing. Effectively solves

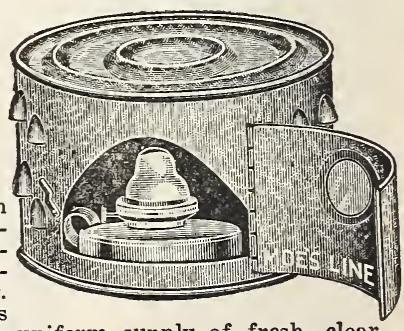
the problem of a uniform supply of fresh, clear water at all times, no matter how cold the weather.

The lamp fount or bowl holds sufficient kerosene to burn for seven days. Simple and safe. Nothing to get out of order.

No. 10 Heater, $\$ 1.80$ each; Postpaid, $\$ 2.00$.

\section{CAPONIZING TOOLS}

Write for booklet that will give information as how your market stock may be made to yield $100 \%$ more. It

is done with $\mathrm{ne}$ POULTRY MARKERS

A reliable poultry punch for marking chicks in the web between the toes. Postpaid-25c each. PORCELAIN or CHINA NEST EGGS

Made of good quality glass, difficult to break, and will last a life time.

Price-Doz. 30c. Postpaid, 35c.

OVINAPTHAL NEST EGGS

A medicated egg which keeps nest and eggs free from lice, mites, etc.

Postpaid-10c each; $\$ 1.00$ per dozen. 
POULTRY SUPPLIES-Continued.
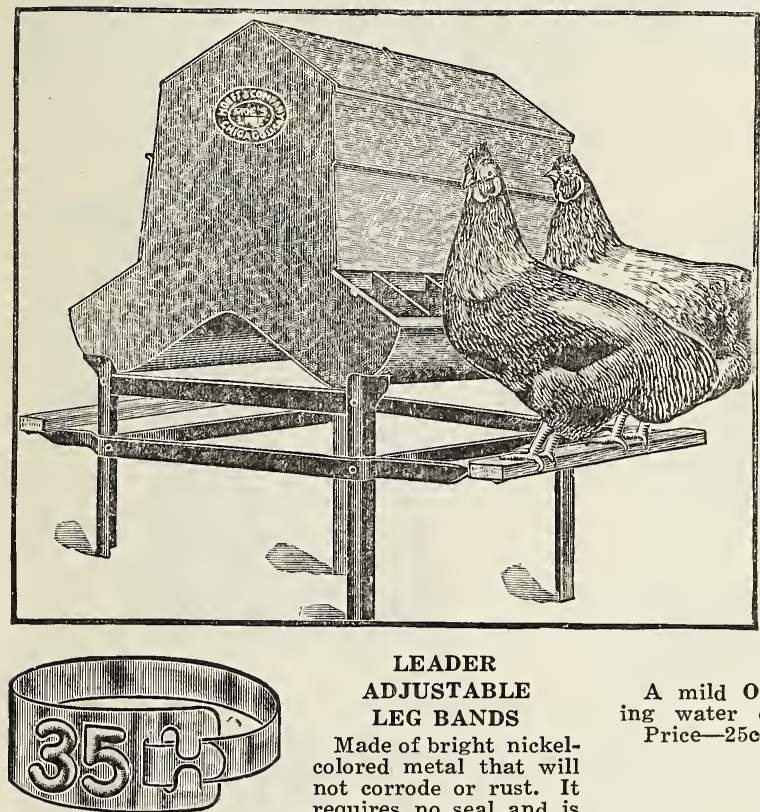

LEADER

ADJUSTABLE

LEG BANDS

Made of bright nickelcolored metal that will not corrode or rust. It requires no seal and is adjustable to the leg of any fowl. Numbers in large raised letters.

12 bands 25 bands------15c 50 bands_-----_45c.

ADJUSTABLE PIGEON BANDS

12 bands___-_15c 50 bands__-_-_-_45c.

25 bands

CELLULIOD BANDS

In all colors for poultry, baby chicks, pigeons. Doz. $20 \mathrm{c} ; 25$ for $45 \mathrm{c} ; 100$ for $\$ 1.25$.

DON SUNG-Tablets for making hens lay; a tonic and conditioner; $50 \mathrm{c}$ and $\$ 1.00$.

POULTRY TABLETS-For White Diarrhea in Chicks, $\$ 1.00$. Box for each hundred chicks tor 60 days.

\section{Oat Sprouter}

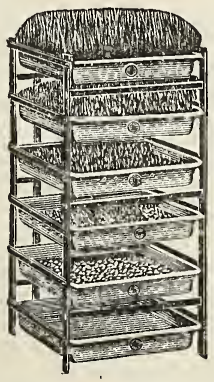

Made entirely of metal. Strong and rigid. Provides the very necessary green feed at all seasons. Healthy chickens and more eggs.

The frame is of steel, well braced and neatly painted. Has six heavy galvanized iron pans. Five of the pans have perforated bottoms to secure the proper drainage, and the bottom pan is solid to hold the drippings. Pans are interchangeable. Sectional frame can be quickly taken apart and stored in a small place.

Total height of frame 3 feet. Size of pans 16 inches by 18 inches.

No. 110-Oat Sprouter Each $\$ 6.00$.

\section{Mammoth Dry Mash Hopper}

A large capacity hopper built on correct principles. Made of heavy galvanized iron, strong and substancial in every detail.

Has many excellent features ; for instance it will accommodate a full 100 th. bag of mash, doing away with the annoyance and waste of having a partly empty bag of mash on the premises. The feed is within easy reach of the chickens, and is protected from the weather and from the ravages of rats and mice.

The taper shape and interior construction provides a uniform automatic feed, and the wire grid and cross wires prevents any waste.

The stand is of heavy angle iron, painted, and has wooden bars for the poultry to rest on when feeding.

No. 3-Hopper and stand complete.

Price each, $\$ 9.50$.

\section{AVICOL}

A mild Oxidizing Agent to be used in drinking water of chickens, pigeons and turkeys. Price-25c each, postpaid.

\section{Miscellaneous}

\section{BLACK FLAG}

For the destruction of ants, bed bugs, flies, fleas, roaches, moths, and insects that infest households and plants.

Postpaid- $3 / 4$ oz. size $25 \mathrm{c} ; 13 / 4$ oz. size $45 \mathrm{c}$.

\section{COW EASE}

A light spray to prevent flies, gnats, mosquitoes. Protect your horses and cows.

By express-1 qt. $50 \mathrm{c}$; $1 / 2$ gal. $85 \mathrm{c} ; 1$ gal. $\$ 1.50$.

\section{FUMIGATING CANDLES}

They are easy to light, easy to extinguish, and safe to use. The vapor is deadly to all infectious insect life.

Price-15c each; $\$ 1.50$ dozen.

\section{RED CROSS RAT EMBALMER}

Endorsed by the U. S. Government. It leaves no odor. It dries them up.

Price $50 \mathrm{c}, \$ 1.00, \$ 3.00$.

\section{WATER GLASS}

For preserving eggs. Will keep them fresh from six to ten months. Put up when eggs are cheap, use them when they are high.

One Gallon enough solution for 50 dozen.

1 quart can, 50c. Postpaid-60c.

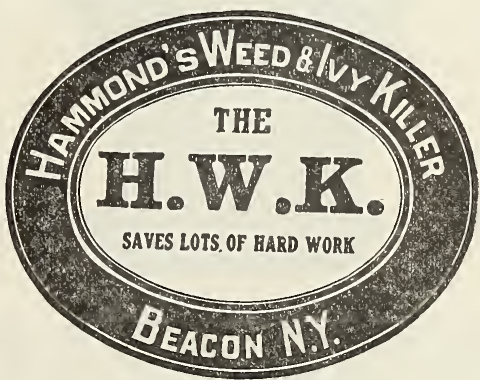

PATH AND GUTTER CLEANER

Quart can 75c. Cannot ship by mail. 


\section{BIRDS AND BIRD SUPPLIES}

Our line of birds and bird supplies ineludes Canaries, Paroquets, Parrots, etc., and all necessary artic'es for their comfort and care.

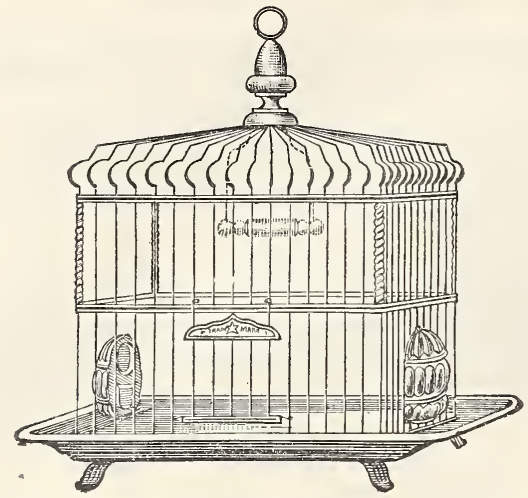

We guarantee our males to sing. All birds are shipped via express and at the purchaser's risk. Male Canaries (singers) Female Canaries _-_-_-_-_-_ $\$ 2.00$ to $\$ 3.00$ Paroquets, per pair -_-_-_-_-_-_-_ $\$ 7.50$ Parrots

Postpaid

Philadelphia Bird Seed, pkt. Mixed Bird Seed (bulk,) tb. Bird Manna, pkt. Song Restorer, pkt. -

Bird Tonic, pkt. $-30 \mathrm{c}$

Cuttle Fish Bone and holder -Silver Bird Gravel, pkt. Red Bird Gravel, pkt Bird Cages, all styles, from Write for size and prices.

\section{GOLD FISH AND SUPPLIES}

We carry a large stock of common and fancy gold fish for delivery from September to April each year. The prices of these fish range from 10 cents to 60 cents each. We also have for delivery, postage, paid, at all times, the following:

Fish Bowls from Aquariums Fish Food (wafer), pkt. Castles

\section{FLOWER POTS AND SAUCERS}

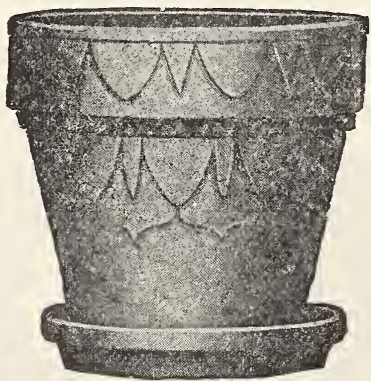

We carry a complete line of standard pots and saucers, azalea pots, bulb dishes, fern dishes, hanging pots, jardinieres, etc.

Write for prices.

\section{EMPIRE MILKING MACHINE}

The most satisfactory machine on the market. This machine will pay for itself in six months in the amount of labor it saves. Write for catalogue or call and let us demonstrate.

We are able to quote you a very low price at this time.

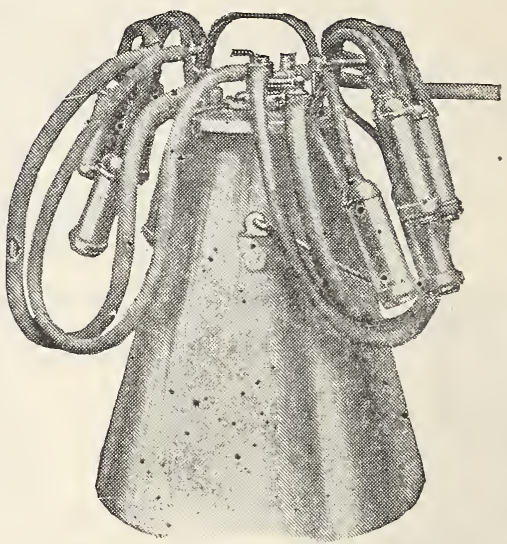

An Empire Double-Unit Milker
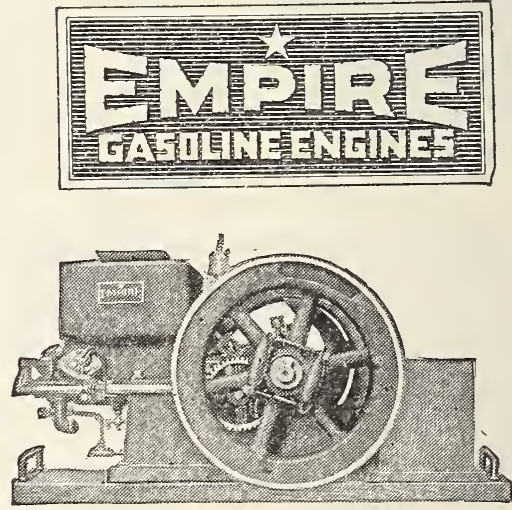

EMPIRE GASOLINE ENGINE

The most dependable engine on the market, as it has very few moving parts. Famous for its refusal to get out of order. Call and let us explain it to you or write for catalogue.

We have in stock a complete line and can quote very low prices for immediate delivery.

\section{IMPORTED RAFFIA}

We can supply at all times both Natural and Colored Raffia. It is used chiefly for basketmaking, many finding this work not only pleasant, but profitable. Raffia is also used for tieing packages, vegetables, etc.

Natural Raffia, postpaid, og. 10c; $1 / 4$ tb. 20c; th. $60 \mathrm{c}$.

Colored Raffia (green, brown, red, blue or purple), postpaid, oz. $15 \mathrm{c} ; 1 / 4$ tb. $35 \mathrm{c}$; 1b. $\$ 1.00$

Manufactured Nu-Reed, any size.

Postpaid-Oz., 10c; 1/4 1b., 25c; 1b., 80c. Raffia Needles, 35c pkt.

\section{METAL EGG CRATES}

For shipping Eggs and butter by Parcel

Post. Write for sizes and prices. 
ORDER BLANK FOR SEEDS, ETC.

ASHEVILLE SEED CO., gives no warranty. expressed or implied, as to description, quality, productiveness, or any other matter, of any seeds, bulbs or plants they send out, and they will not be in any way responsible for the crop. If the purchaser does not accept the goods on these terms, they are at once to be returned.

\section{ASHEVILLE SEED COMPANY,} ASHEVILLE, N. C.
Please Do Not Write Here

Date Received

Date Filled.

Filled by

Shipped by

Order No.

\section{Date} 19

PLEASE FILL IN THESE BLANKS PLAINLY

Dear Sirs:-

Please send the following Seeds, etc., by (State here if wanted by Mail, Express or Freight)

Name

P. O. Box

Post Office

R. F. D

County State

Express or Freight Office

(If different from Post Office)

\section{Amount Enclosed}

Check

P. O. Money Order

Exp. Money Order

C:ash_

Stamps

ABOUT PRICES:-We pay postage on PACKETS, OUNCES, AND QUARTER POUNDS; all prices in this Catalogue, excepting where otherwise noted, are based on customer paying Express or Freight.

See Parcel Post Rates Page 3

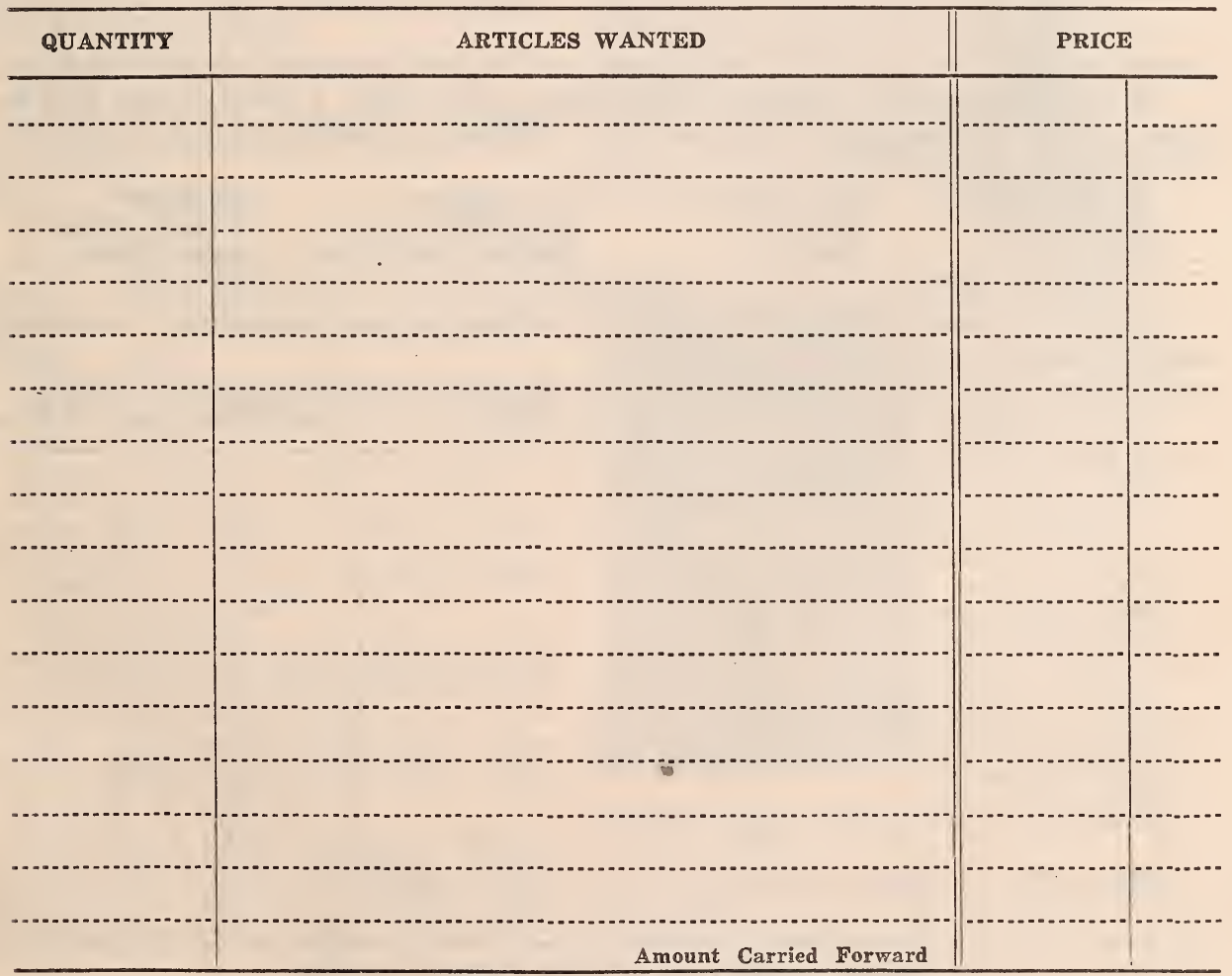


EXTRA ORDER SHEETS AND RETURN ENVELOPES FURNISHED ON REQUEST

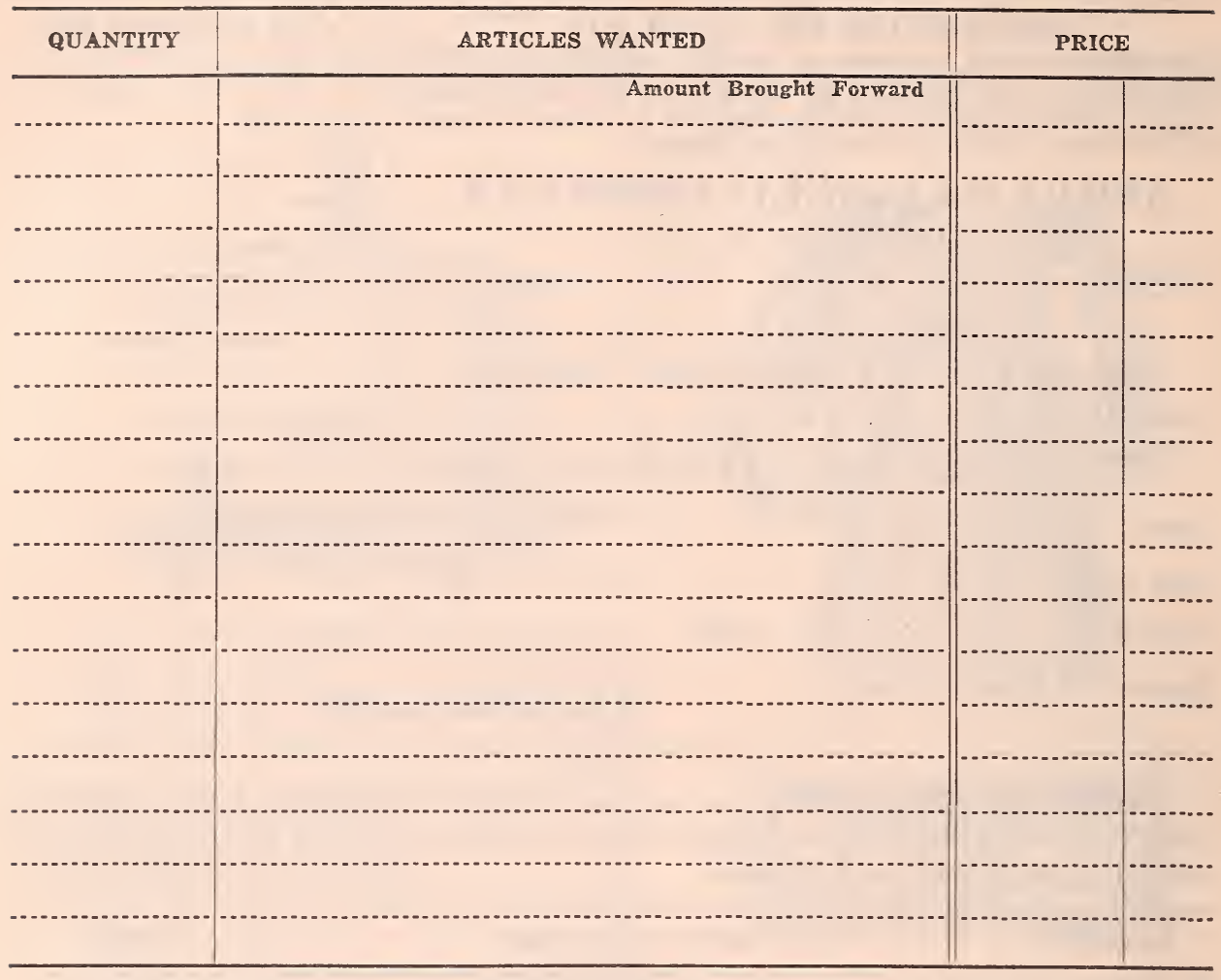

By carefully checking this list before sending your order, a great saving may be made in transportation cost, and you may also find that an important and an immediate necessity has been omitted.

$\begin{array}{ll}\text { Garden Seed } & \text { Lawn Seed } \\ \text { Flower Seed } & \text { Bulbs } \\ \text { Field Seed } & \text { Fertilizers } \\ \quad \text { Poultry Supplies } & \end{array}$

Insecticides
Fungicides
Dusting Materials
Incubators

\section{Sprayers Garden Tools Lawn Tools} Feeds, Etc.

Kindly list below the names of any friends whom you think interested in receiving our catalogue.

\begin{tabular}{ll|l|l|l|}
\hline NAME & POST OFFICE & STATE R. F. D. P. O. BOX \\
\hline & & & \\
\hline
\end{tabular}




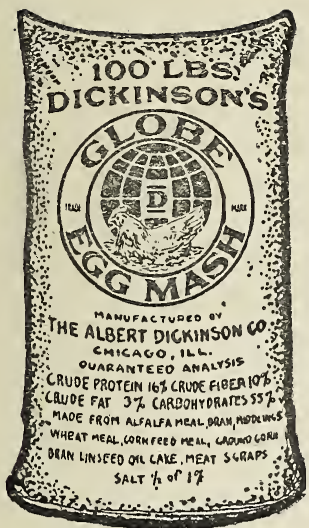

Poultry and Stock Feeds

The popularity of our poultry feeds in Western North Carolna has encouraged us to add a complete line of first quality dairy, horse, and stock feeds. Our feeds are carefully formulated and mixed from the choicest ingred ents used for feeding stock. They have stood the most painstaking tests and have produced enviable results for their many users.

The prices of all grain feeds fluctuate constantly, hence it is not possible to list prices in this catalogue. Prices and samples will be submitted on application.

GLOBE SCRATCH FEED-An evenly balanced ration mixed from sound, clean, and bright grains, Feed with Globe Egg Mash for maximum production at the minimum cost.

GLOBE EGG MASH-Formulated from meat scraps, linseed oil meal, bran, corn meal, middlings, and alfalfa meal. It contains the essential digestible protein so necessary for egg production.

Write for price.

GLOBE CHICK FEED-This balanced and finely along with butter milk feeds to obtain the best results. The chick will grow better and mature earlier since the combination of the grain and buttermilk feeds build tissue, bone and body.

Write for price.

GLOBE PIGEON FEED-Best for every breed. Made from wheat, buckwheat, kafir corn, peas, millet and hemp.

Write for prices.

CRUSHED OYSTER SHELL-Should be kept available for fowls at all times; forms egg shells and keeps stock healthy.

Price-Of coarse or fine.

Postpaid: 5 lbs. $25 \mathrm{c}$; 10 ibs. $45 \mathrm{c} ; 25$ lbs. $\$ 1.05$.

Express: Per 1b. 3c; per 100 tbs. $\$ 2.00$.

LIME GRIT-A necessity for both young and old stock. Don't expect your birds to grind their food with oyster shells.

Price-Of coarse or fine

Postpaid: 5 tbs. 25c; 10 tbs. 45c; $25 \mathrm{tbs} . \$ 1.05$.

Express: Per tb. 3c; per 100 tbs. $\$ 2.00$.

CHARCOAL-Aids digestion; purifies the blood and generally promotes the good health and vigor of your birds.

Price of coarse or fine.

Postpaid: Per tb. $13 \mathrm{c}$; per 251bs. $\$ 2.05$

Express: Per to. 7c; per 50 1bs. $\$ 2.50$.

RIVAL HOG FEED-A well balanced ration worked out by scientists through exhaustive experiments and chemical analysis. It positively supplies the food element for hogs in all growing stages.

Write for price.

GREEN CUT ALFALFA MEAL-A green food mixed in poultry mash feeds and stock feeds. Write for price.

GROUND OATS-For poultry and stock.

Write for price.

PURE WHEAT BRAN-We carry only the best grade. Write for price.

SHORTS-Red Dog, Gray and Brown Shorts, argely used for both poultry and stock.

Ask for our prices.

BLATCHFORD'S CALF MEAL-The oldest, best known and most widely used calf meal in America. Write for price and information as to the virtues of this money saver.

MILK BONE DOG BISCUITS-MILK BONE PUPPY BISCUITS-Pure food for dogs, a complete scientifically balanced food.

Postpaid: $30 \mathrm{c}$ and $60 \mathrm{c}$

BLACKMAN'S MEDICATED SALT BRICKThe best Salt Brick on the market. A worm medicine, blood purifier, kidney regulator. Tonic and appetizer for all classes of live stock. Write for price of case lots. Postpaid: 25c. Express : $\$ 2.25$ per dozen; $\$ 5.75$ per case.
GLOBE GROWING MASH-Made especially for little chicks to be fed in the growing stage.

Write for prices.

GLOBE DEVVELOPING GRAIN-To be fed in connection with Growing Mash Made of bright, clean grain which can be fed to growing chicks with practically no waste.

BEEF SCRAPS-Is high in protein and an essential egg producer and muscle builder.

Write for price.

GLOBE HOISE FEED-Not a better horse feed on the market. 90\% Grain Mixture sweetened with molasses. Not necessary to feed oats and other grains as with molasses feeds. Price fluctuates. Write for prices.

OASIS HORSE FE E D-

This feed is performing every function $f \mathrm{rom}$ nursing the weakling colt to supplying hard strains of racing, hunting and heavy work horses contains the elements that build up muscle and tissue in large, consistent proportions. Composed of alfalfa, molasses, and heavy grain mixture. Price fluctuates. Write for prices.
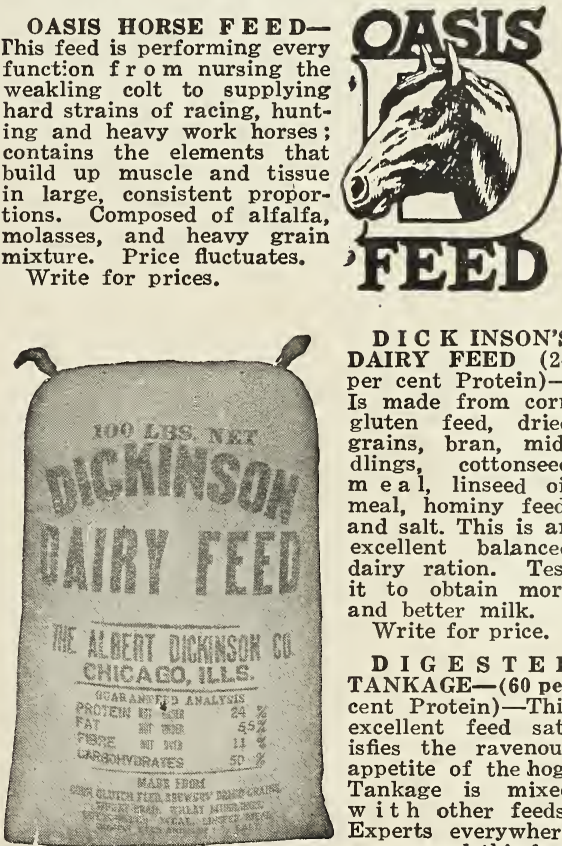

D I C K INSON'S DAIRY FEED (24 per cent Protein) Is made from corn gluten feed, dried grains, bran, middlings, cottonseed $\mathrm{m}$ e a 1 , linseed oil meal, hominy feed, and salt. This is an excellent balanced dairy ration. Test it to obtain more and better milk.

Write for price.

D I G E S T E R TANKAGE- $(60$ per cent Protein)-This excellent feed satisfies the ravenous isfies the ravenous Tankage is mixed w it h other feeds. Experts everywhere recommend this feed as a great muscle and meat maker. It will realize more profit from your hogs. Write for price.

RABBIT FEED-A mixture of alfalfa, grain, and molasses which supplies all necessary food for rabbits.

Write for price. 
